INFORMES

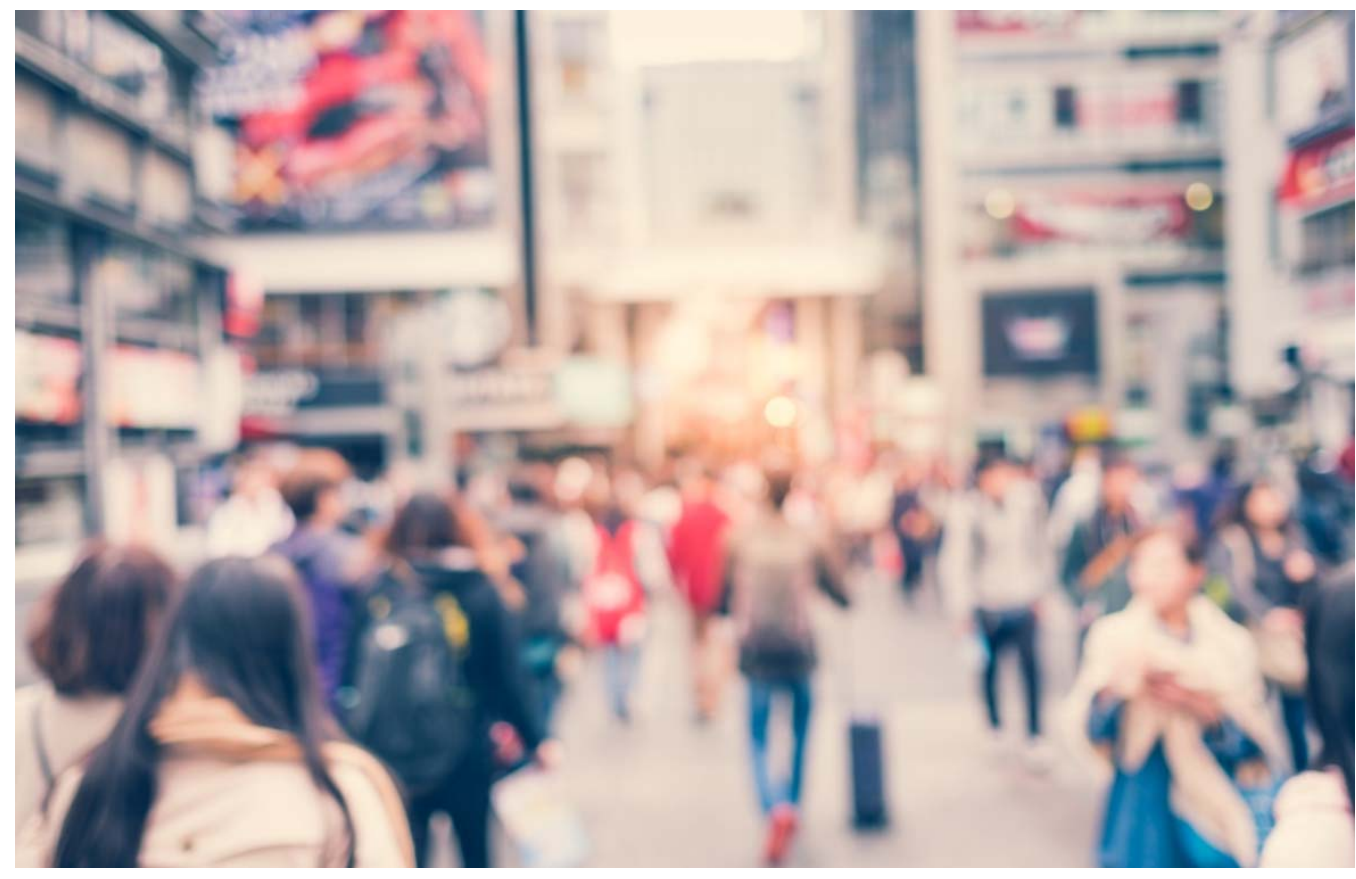

OFERTA, DEMANDA E PRÁCTICAS CULTURAIS NOS MENORES DE 16 ANOS

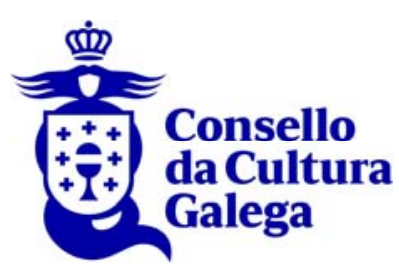




\section{TÁBOA DE CONTIDOS}

1. INTRODUCCIÓN

2. METODOLOXÍA 6

3. AVALIACIÓN DA OFERTA CULTURAL EN GALICIA 8

4. AVALIACIÓN DA OFERTA CULTURAL EN GALEGO PARA MENORES DE 16 ANOS 15

4.1. LIBROS 16

4.2. ESPECTÁCULOS 21

4.3. CINE EN SALA 25

4.4. MÚSICA 30

4.5. MUSEOS E EXPOSICIÓNS

4.6. TELEVISIÓN

4.7. CONTIDOS AUDIOVISUAIS 40

4.8. XOGO TRADICIONAL E VIDEOXOGOS 45

5. CONSUMO DE CONTIDOS CULTURAIS ENTRE MENORES DE 16 ANOS 50

5.1. LIBROS 52

5.2. PUBLICACIÓNS E REVISTAS 60

5.3. MÚSICA 63

5.4. ESPECTÁCULOS 66

5.5. CINE EN SALA 74

5.6. MUSEOS E EXPOSICIÓNS

5.7. TELEVISIÓN

5.8. CONTIDOS AUDIOVISUAIS 88

5.9. XOGO TRADICIONAL E VIDEOXOGOS 93

6. CONTIDOS CULTURAIS MÁIS IMPORTANTES QUE CÓMPRE POTENCIAR 95

7. DISPOSICIÓN OU INTERESE EN AGASALLAR ALGÚN CONTIDO CULTURAL AOS MENORES DE 16 ANOS 101

8. OFERTA, DEMANDA E CONSUMO DE PRODUTOS CULTURAIS 110

8.1. VALORACIÓN DA OFERTA CULTURAL SEGUNDO O CONSUMO DOS
MENORES DE 16 ANOS

8.2. VALORACIÓN DA OFERTA CULTURAL SEGUNDO A LINGUA DE

8.3. RELACIÓN DA PERCEPCIÓN DA OFERTA COA VONTADE DE REGALAR CULTURA

9. CONCLUSIónS

121 


\section{INTRODUCIÓN}

Este traballo de investigación xorde motivado fundamentalmente polo interese de pulsar a opinión da poboación galega sobre a situación actual da oferta cultural en Galicia, poñendo o foco de xeito especial naquela que vai dirixida ao colectivo de menores de 16 anos e na que que se ofrece en lingua galega. Ademais, aborda outras cuestións vinculadas ás propostas culturais existentes, como as preferencias, prácticas e tendencias no consumo de produtos culturais, a avaliación dos tipos de contido das propostas culturais, así como o nivel de suficiencia ou escaseza destas propostas cara á cidadanía, entre outras.

O Consello da Cultura Galega sinalou noutros informes publicados con anterioridade ${ }^{1}$ a escaseza de oferta de produtos e servizos en lingua galega nalgúns ámbitos da cultura. Constatouse unha escasa presenza de manifestacións culturais galegas no espazo dixital, polo que se aconsellaba reforzar políticas públicas destinadas a potenciar o tecido de medios de comunicación e plataformas dixitais de cultura en lingua galega. Tamén se indicou que a ausencia de programacións integrais no campo do ensino aconsellan o estudo e, de ser o caso, a aplicación de iniciativas de comunicación e cultura que permitan un bo coñecemento sobre como funciona o ecosistema comunicativo e cultural.

Esta institución detectou tamén a existencia dalgunhas lagoas de datos primarios que recomendaban dispoñer de indicadores básicos dos sectores da cultura galega, co fin de analizar o estado conxunto do ecosistema cultural e ter información precisa para todos os sectores. Así mesmo, indicábase que son moi escasos os estudos sobre usos e consumos culturais que resultan esenciais á hora de planificar políticas públicas.

Tamén houbo unha serie de achados e recomendacións relacionadas co consumo de produtos culturais entre a mocidade noutro informe do Consello da Cultura Galega, que estudou as prácticas e actitudes lingüísticas da xente nova en Galicia ${ }^{2}$. Concretamente, dicíase que o grao de exposición ao galego ofrece índices baixos no relacionado cos medios de comunicación, con manifestacións do lecer e coas novas tecnoloxías. Tamén se detectara unha baixa identificación da mocidade coa música galega e unha necesidade de que a lingua que se transmita nos medios de comunicación tivese unha calidade lingüística satisfactoria, manifestada nos indicadores de corrección e de variedade.

Nesa mesma investigación tamén se indicaba que os poderes públicos deben apoiar e fomentar a investigación sobre a mocidade e a lingua para que exista unha continuidade dos estudos deste tipo.

Con anterioridade, este órgano consultivo tamén destacaba ${ }^{3}$ que a cidadanía se mostraba moi favorable a unha maior presenza do galego nos produtos de entretemento para a cativada e a xente nova e que as actitudes globalmente contrarias ás políticas de promoción do galego son claramente minoritarias en Galicia.

\footnotetext{
${ }^{1}$ http://consellodacultura.gal/mediateca/extras/CCG 2018 Diagnose-para-a-cultura-galega.pdf ${ }^{2}$ http://consellodacultura.gal/mediateca/extras/CCG_2017_Practicas-e-actitudes-linguisticasda-mocidade-en-Galicia.pdf

${ }^{3}$ http://consellodacultura.gal/mediateca/extras/CCG 2012 As-linguas-a-debate-Inqueritosobre-opinions-actitudes-e-expectativas-da-sociedade-galega.pdf.
} 
Os hábitos culturais da infancia e a relación dos hábitos familiares co consumo de cultura tamén se abordaron en informes do Consello da Cultura Galega $^{4}$. Así, púxose de manifesto que, en xeral, a poboación galega participa menos en actividades culturais na súa infancia que a media de España. Asemade, destacouse a mediación paterna e materna nesta etapa vital, xa que semellaba existir unha influencia positiva dos proxenitores nos hábitos de lectura, na asistencia ao cine, a espectáculos escénicos e musicais e a museos. Outro achado foi que os pais e nais galegos tenden a acompañar as crianzas nas actividades culturais nunha medida parecida á do conxunto das nais e pais españois.

O presente informe ${ }^{5}$ que elaborou o Observatorio da Cultura Galega pretende continuar afondando nos estudos sobre os hábitos culturais da poboación galega. Os principais aspectos analizados ${ }^{6}$ son a valoración sobre a oferta cultural, se esta se considera suficiente ou non e a opinión das persoas sobre a situación da oferta cultural en Galicia, especialmente sobre as necesidades, costumes e prácticas relacionadas coa cultura e a lingua galega entre menores de 16 anos.

Os obxectivos específicos céntranse en coñecer a valoración que outorga a poboación á oferta cultural en Galicia, á oferta para menores de 16 anos e, especificamente, a valoración que lle da á oferta en galego para a cativada.

Interesa, ademais, saber se é suficiente ou non a oferta de determinados contidos culturais, así como coñecer o consumo destes contidos culturais en galego entre menores de 16 anos. Así, os produtos analizados son os seguintes:

- Lectura e compra de libros.

- Espectáculos como teatro, ópera, ballet.

- Cine en sala.

- Música.

- Museos.

- Televisión.

- Contidos audiovisuais.

- Xogos (tradicionais e videoxogos).

Por último analizouse a disposición que terían as persoas enquisadas a ofrecer ou regalar algún contido cultural a menores de 16 anos que puidese haber no seu contorno.

Os contidos do informe inclúen, despois desta breve introdución, un apartado de metodoloxía que dá conta dalgúns aspectos técnicos da investigación. $\mathrm{O}$ seguinte capítulo aborda a valoración que dá a poboación galega con respecto á

\footnotetext{
${ }^{4} \mathrm{http}$ //consellodacultura.gal/mediateca/extras/CCG_2020_Habitos-e-practicas-culturais-enGalicia.pdf

${ }^{5} \mathrm{O}$ traballo é o resultado dun convenio de colaboración entre o Consello da Cultura Galega e a Secretaría Xeral de Política Lingüínstica da Xunta de Galicia.

${ }^{6}$ A execución do traballo de campo foi labor da empresa Instituto Sondaxe S.L.
} 
oferta cultural en Galicia en xeral, a oferta cultural para todas as persoas menores de 16 anos e a oferta cultural en galego para este colectivo en particular.

No cuarto apartado estúdase a abundancia ou carencia de oferta cultural en galego para menores de 16 anos.

O quinto apartado describe como é o consumo actual de contidos culturais entre menores de 16 anos nos fogares galegos, tanto en lingua galega como en xeral. Para isto analizáronse os produtos culturais arriba referidos.

O sexto capítulo analiza cales son os contidos da oferta cultural dirixida á rapazada que habería que mellorar, segundo a importancia que lles outorgan as persoas entrevistadas da mostra.

No antepenúltimo capítulo do informe descríbese a disposición das persoas enquisadas a ofrecer ou agasallar contido cultural á cativada que puidese haber no seu contorno.

O penúltimo apartado analiza a relación que existe entre algunhas das variables dependentes máis destacadas do estudo, nomeadamente entre a percepción da suficiencia ou insuficiencia da oferta en galego das persoas entrevistadas e o consumo de produtos dos menores que viven con eles, ou a relación que podería ter esa percepción da insuficiencia de oferta coa distancia entre o consumo en xeral e en lingua galega, entre outras.

Pechan o traballo as conclusións, onde se poñen en relación os principais achados do traballo. 


\section{METODOLOXÍA}

A información para a elaboración do presente informe obtívose a través da realización dunha enquisa específica á poboación galega baseada nun cuestionario estruturado no que se recollían os obxectivos da investigación.

Os parámetros técnicos da enquisa realizada son os seguintes:

- Ámbito: Galicia.

- Universo: Poboación residente en Galicia de 16 ou máis anos de idade.

- Mostra: 900 entrevistas. Fíxose unha submostra de 401 entrevistas en fogares con menores de 16 anos e outra submostra de 499 en fogares sen menores de 16 anos.

- Tipo de entrevista: Telefónica asistida por ordenador (sistema CATI).

- Afixación da mostra: Determinación óptima segundo a provincia e dentro de cada provincia afixación proporcional segundo o tamaño da poboación dos concellos de residencia.

- Selección das entrevistas: Selección dos fogares mediante semente aleatoria dunha base de teléfonos dos concellos de Galicia; cotas de idade e xénero para seleccionar á persoa que se ía entrevistar.

- Marxe de erro: + 3,10\% cun nivel de confianza do 95,5\% (2 sigmas), no caso de máxima indeterminación $(\mathrm{p}=\mathrm{q}=50 \%)$ e para resultados globais.

- Traballo de campo: do 28 de xullo ao 2 de setembro de 2021.

- Empresa responsable: Instituto Sondaxe, S.L.

En canto ao tratamento de datos, as variables consideradas independentes nas hipóteses de investigación e coas que se traballa para explicar os resultados acadados foron as seguintes:

- Idade.

- Xénero.

- Nivel de estudos rematados.

- Situación laboral.

- Menores de 16 anos no fogar.

- Ingresos mensuais do fogar.

- Lingua que fala habitualmente.

- Lingua en que aprenderon a falar as crianzas.

- Tipoloxía do contorno de residencia (cidade grande, vila de tamaño medio, vila pequena, núcleo pequeno ou aldea).

- Provincia.

- Tamaño do hábitat de residencia. 
- Actividades culturais realizadas.

- Subscrición a plataformas de contidos culturais (p. ex.: series, televisión, música, libros, videoxogos, prensa etc.).

- Grao de equipamento cultural do fogar: libros, smart TV, PC ou portátil, tableta, consola, reprodutores de música, libro dixital.

É importante destacar que a variable “Grao de equipamento” foi recodificada para facilitar a súa análise e interpretación. En principio preguntábaselles ás persoas enquisadas se tiñan unha serie de equipos na casa e, segundo o número de equipos, a recodificación aplicada foi a seguinte: de 1 a 2 nivel baixo, de 3 a 5 nivel medio e de 6 a 7 nivel alto de equipamento.

Noutros casos, malia que se tiveron en conta sempre todas as categorías de resposta, só se visualizan nas gráficas as que resultaron relevantes para a análise. Por exemplo, na variable que dá conta da lingua en que se lles fala a fillos/as, evítase sinalar a categoría "Non ten fillos".

No último capítulo faise unha análise para medir a relación das principais variables dependentes do estudo, nomeadamente o consumo cultural en galego das familias, a percepción da suficiencia/insuficiencia da oferta cultural e a vontade de agasallar produtos culturais en galego. Para probar se existen diferenzas entre a distancia entre consumo en xeral e en galego e a percepción de suficiencia/insuficiencia de produtos en galego, créase unha variable onde se tenta analizar esa distancia (entre consumir en xeral e consumir en galego).

Neste traballo preséntase só a relación coas variables que resultaron significativas $^{7}$, é dicir, nos casos en que se observaron diferenzas significativas na distribución dos niveis das variables, cando se analizan variables numéricas e cualitativas. Cando se trata das variables categóricas, preséntanse só as variables en que se comproba que a variable dependente se modifica entre os distintos niveis da independente.

\footnotetext{
${ }^{7}$ As probas de significación utilizadas foron khi-cadrado de Pearson para analizar a independencia de dúas variables categóricas. No caso de que se estude unha variable numérica e outra categórica, utilízase o test de Kruskal-Wallis para máis de dous grupos e o test de Mann-Whitney para dous grupos, ambos os métodos non paramétricos utilizados para probar se un grupo de datos provén da mesma poboación. O nivel de confianza utilizado foi do 95\%.
} 


\section{AVALIACIÓN DA OFERTA CULTURAL EN GALICIA}

Neste capítulo descríbese a valoración que dá a poboación galega con respecto á oferta cultural en Galicia en xeral, á oferta cultural para todas as persoas menores de 16 anos e á oferta cultural en galego para este sector da poboación en particular.

Valoración global da oferta cultural en Galicia (Valores medios nunha escala 0-10)

\begin{tabular}{lc} 
& Media \\
\hline Xeral & 6,15 \\
Enfocada a menores de 16 anos & 5,56 \\
Enfocada a menores de 16 anos en galego & 5,01 \\
\hline \multicolumn{2}{c}{ Fonte: Elaboración propia }
\end{tabular}

Na escala utilizada, entre 0 e 10 puntos, a avaliación media outorgada pola poboación galega á oferta cultural global en Galicia foi de 6,15 puntos. Con respecto á oferta cultural para menores de 16 anos, a valoración foi de 5,56 puntos, aínda que a oferta cultural en galego para este sector da poboación foi a que acadou a avaliación máis baixa das tres $(5,01)$.

A continuación preséntase a relación coas variables independentes que resultaron con diferenzas significativas na distribución das súas categorías. Co obxectivo de comparar cada valoración da oferta cultural, tanto en xeral, como a oferta cultural en galego para menores de 16 anos en particular, elixíronse aquelas variables independentes nas que resulta significativa en polo menos un dos casos.

En relación coa idade, pódese comprobar que canto maiores son as persoas enquisadas, peor tende a ser a valoración da oferta cultural. Así, as persoas de 65 e máis anos son as que proporcionan unha valoración máis negativa da oferta cultural en xeral. Con respecto á oferta cultural xeral e en galego enfocada a menores de 16 anos, quen outorga a puntuación máis baixa é o grupo de idade de entre 45 a 64 anos.

\section{Valoración da oferta cultural segundo a idade (Valores medios nunha escala 0-10)}

\begin{tabular}{lccc} 
& $\begin{array}{c}\text { Oferta cultural } \\
\text { xeral }\end{array}$ & $\begin{array}{c}\text { Enfocada a menores } \\
\text { de 16 anos }\end{array}$ & $\begin{array}{c}\text { Enfocada a menores } \\
\text { de 16 anos en galego }\end{array}$ \\
\hline De 16 a 29 & 6,55 & 5,91 & 4,96 \\
De 30 a 44 & 6,37 & 5,65 & 5,00 \\
De 45 a 64 & 6,03 & 5,37 & 4,87 \\
65 e máis anos & 5,90 & 5,54 & 5,24 \\
\hline \multicolumn{4}{c}{ Fonte: Elaboración propia }
\end{tabular}

Se se analizan os datos de valoración da oferta cultural por provincias, en xeral pode concluírse que son as provincias de interior, Lugo e Ourense, as que peor valoran a oferta cultural xeral e a dirixida a menores de 16 anos. A Coruña é a provincia en que, en xeral, mellor se valora a oferta cultural, aínda que hai unha diferenza de máis dun punto entre a puntuación que se lle outorga á oferta cultural xeral e á oferta en galego dirixida a menores de 16 anos.

A oferta cultural en galego para menores de 16 anos é a peor valorada nas catro provincias, cunha puntuación media de 5 puntos, agás en Ourense, onde nin 
sequera chega ao 5. Por último, cómpre salientar que a oferta cultural xeral é a que está mellor valorada nas catro provincias, superando os seis puntos de valoración, agás en Ourense, onde fica en 5,72 puntos.

Valoración da oferta cultural segundo a provincia (Valores medios nunha escala 0-10)

\begin{tabular}{lccc} 
& $\begin{array}{c}\text { Oferta cultural } \\
\text { xeral }\end{array}$ & $\begin{array}{c}\text { Oferta cultural para } \\
\text { menores de 16 anos }\end{array}$ & $\begin{array}{c}\text { Oferta cultural en galego } \\
\text { para menores de 16 anos }\end{array}$ \\
\hline A Coruña & 6,34 & 5,72 & 5,20 \\
Lugo & 6,13 & 5,48 & 5,04 \\
Ourense & 5,72 & 5,12 & 4,52 \\
Pontevedra & 6,15 & 5,64 & 5,02 \\
\hline
\end{tabular}

Fonte: Elaboración propia

Os resultados obtidos ao analizar o nivel de estudos das persoas enquisadas, en termos xerais, indican que, a maior nivel de estudos, a valoración que se lle outorga á oferta cultural é máis baixa nos tres casos. Tanto a oferta cultural xeral como aquela que vai dirixida a menores de 16 anos obteñen en todos os casos unha puntuación superior a 5 puntos, mentres que a oferta cultural en galego para menores de 16 anos non acada esta puntuación, agás no caso das persoas entrevistadas con estudos primarios, que lle outorgan unha nota de 5,67 puntos. Ademais, en todos os casos a puntuación que se lle outorga á oferta cultural en galego enfocada a menores de 16 anos é máis baixa, especialmente cando se trata das persoas con estudos universitarios, na que hai unha diferenza de 1,3 puntos. Isto implica que, a maior nivel de estudos, percíbese maior diferenza na valoración entre a oferta cultural xeral e a oferta en galego que vai dirixida a menores de 16 anos.

\begin{tabular}{lccc} 
& $\begin{array}{c}\text { Valoración da oferta cultural segundo o nivel de estudos } \\
\text { (Valores medios nunha escala de 0-10) } \\
\text { Oferta cultural } \\
\text { xeral }\end{array}$ & $\begin{array}{c}\text { Enfocada a meno- } \\
\text { res de 16 anos }\end{array}$ & $\begin{array}{c}\text { Enfocada a meno- } \\
\text { res de 16 anos en } \\
\text { galego }\end{array}$ \\
\hline Sen estudos & 7,13 & 7,33 & 5,67 \\
Primarios ou similares & 6,25 & 5,99 & 5,87 \\
Secundarios ou similares & 6,18 & 5,59 & 4,76 \\
Formación Profesional & 6,28 & 5,59 & 4,76 \\
Universitarios medios & 6,00 & 5,47 & 4,98 \\
Universitarios superiores & 5,99 & 5,22 & 4,63 \\
\hline
\end{tabular}

Fonte: Elaboración propia

Se se analizan os resultados sobre a valoración da oferta cultural segundo o hábitat, verifícase que hai certa tendencia a que, canto maior sexa a poboación do lugar de residencia das persoas enquisadas, mellor valoración obtén a oferta cultural. Isto acontece tanto no que se refire á oferta cultural xeral como á que vai dirixida a menores de 16 anos. Se se establece unha comparación entre áreas rurais e zonas urbanas ou periurbanas, pode apreciarse unha diferenza significativa no que se refire á oferta cultural xeral, especialmente en localidades cunha poboación de entre 20.000 e 50.000 habitantes, que é onde obtén maior puntuación (6,42 puntos), fronte ás áreas rurais cunha poboación inferior a 5.000 habitantes $(5,83$ puntos). Por último, cabe destacar que a oferta cultural en galego dirixida a menores de 16 anos é a que recibe peor valoración en todos os treitos de poboación establecidos, cunha puntuación que rolda os 5 puntos, aínda que no caso das áreas rurais e das vilas de entre 10.000 e 20.000 habitantes a 
puntuación outorgada non chega ao 5 . Non se aprecia unha tendencia a que creza a distancia entre linguas conforme decrece o tamaño do hábitat, polo que se podería afirmar que a percepción dunha menor oferta en galego no rural estaría relacionada cunha menor oferta cultural xeral.

Valoración da oferta cultural segundo o hábitat (Valores medios nunha escala de 0-10)

\begin{tabular}{lccc} 
& $\begin{array}{c}\text { Oferta cultural } \\
\text { xeral }\end{array}$ & $\begin{array}{c}\text { Enfocada a meno- } \\
\text { res de 16 anos }\end{array}$ & $\begin{array}{c}\text { Enfocada meno- } \\
\text { res de 16 anos en } \\
\text { galego }\end{array}$ \\
\hline Menos de 5.000 hab. & 5,83 & 5,28 & 4,86 \\
Entre 5.000 e 10.000 hab. & 6,24 & 5,69 & 5,05 \\
Entre 10.000 e 20.000 hab. & 6,06 & 5,4 & 4,74 \\
Entre 20.000 e 50.000 hab. & 6,42 & 6,15 & 5,56 \\
Cidades & 6,21 & 5,52 & 5,03 \\
\hline
\end{tabular}

Fonte: Elaboración propia

En relación coa variable grao de equipamento cultural do fogar, cómpre destacar que, a maior grao de equipamento, a oferta cultural xeral, a dirixida a menores de 16 anos e, sobre todo, a oferta en galego reciben unha puntuación máis baixa. A única que recibe unha puntuación por debaixo de 5 puntos é a oferta en galego para menores de 16 entre aquelas persoas que dispoñen dun grao alto ou medio de equipamento cultural no fogar. Tamén se percibe unha diferenza importante entre a puntuación outorgada á oferta cultural xeral e á oferta en galego dirixida a menores de 16 anos, xa que a maior nivel de equipamento cultural existe unha maior diferenza de puntuación entre a oferta cultural xeral e a oferta en galego dirixida a menores de 16 anos, concretamente 1,25 puntos para as persoas cun grao alto de equipamento cultural, 1,2 para as de grao medio e 0,5 puntos para as de grao baixo.

\begin{tabular}{lccc}
$\begin{array}{l}\text { Valoración da oferta cultural segundo o grao de equipamento cultural } \\
\text { (Valores medios nunha escala de } \mathbf{0} \text { a 10) } \\
\text { Alto }\end{array}$ & Medio & Baixo \\
& & & \\
\hline Oferta cultural xeral & 6,14 & 6,14 & 6,16 \\
Enfocada a menores de 16 anos & 5,54 & 5,41 & 6,11 \\
$\begin{array}{l}\text { Enfocada a menores de } 16 \text { anos } \\
\text { en galego }\end{array}$ & 4,89 & 4,94 & 5,62 \\
\hline
\end{tabular}

Fonte: Elaboración propia

Os datos anteriores están directamente relacionados cos que se ofrecen na seguinte táboa, na que se que cruzan os datos da valoración da oferta cultural coa variable que se refire á subscrición ou non a plataformas dixitais. Os resultados indican unha valoración inferior da oferta cultural por parte das persoas que viven en fogares de dispoñen de subscricións a plataformas dixitais de contidos culturais. 
Valoración da oferta cultural segundo a subscrición a plataformas dixitais de contidos culturais (Valores medios nunha escala de 0 a 10)

\begin{tabular}{lcc} 
& $\begin{array}{c}\text { Están } \\
\text { subscritos/as }\end{array}$ & $\begin{array}{c}\text { Non están } \\
\text { subscritos/as }\end{array}$ \\
\hline Oferta cultural xeral & 6,13 & 6,21 \\
Enfocada a menores de 16 anos & 5,42 & 5,80 \\
Enfocada a menores de 16 anos en galego & 4,85 & 5,28 \\
\hline
\end{tabular}

Fonte: Elaboración propia

Segundo os treitos de ingresos no fogar, pódese observar que, a medida que aumenta o nivel de renda no fogar, peor puntuación obtén a oferta cultural, agás no caso do treito máis elevado de fogares, cuns ingresos de máis de 3.000 euros, entre os que a puntuación é algo máis alta que o chanzo anterior. Esta tendencia é moi clara no caso da oferta cultural en galego para menores de 16 anos, xa que nos tres treitos de ingresos máis elevados non acada os cinco puntos.

\begin{tabular}{lccccc} 
Valoración da oferta cultural segundo os ingresos (Valores medios nunha escala de $\mathbf{0}$ a 10) & $\begin{array}{r}\text { De } 0 \text { a } \\
1.000 €\end{array}$ & $\begin{array}{c}\text { De } 1.001 \text { a } \\
2.000 €\end{array}$ & $\begin{array}{c}\text { De } 2.001 \\
\text { a 3.000 }\end{array}$ & $\begin{array}{c}3.001 € \\
\text { ou máis }\end{array}$ \\
\hline Oferta cultural xeral & 6,33 & 6,15 & 6,00 & 6,16 \\
Enfocada a menores de 16 anos & 5,96 & 5,58 & 5,31 & 5,31 \\
Enfocada a menores de 16 anos en galego & 5,87 & 4,94 & 4,70 & 4,86
\end{tabular}

Fonte: Elaboración propia

Unha vez vista a valoración que se lle dá á oferta cultural en xeral e á dirixida a menores de 16 anos, interesa prestar máis atención á distribución da puntuación que lle outorga a poboación galega á oferta cultural en galego para este sector da poboación. Pode verificarse na seguinte gráfica que a puntuación máis frecuente é a de 5 puntos. O 39,02\% da poboación outorga unha puntuación negativa e o 60,98\% unha puntuación de 5 ou máis.

\section{Valoración da oferta cultural en galego para menores de 16 anos (Valores medios nunha escala 0-10)}

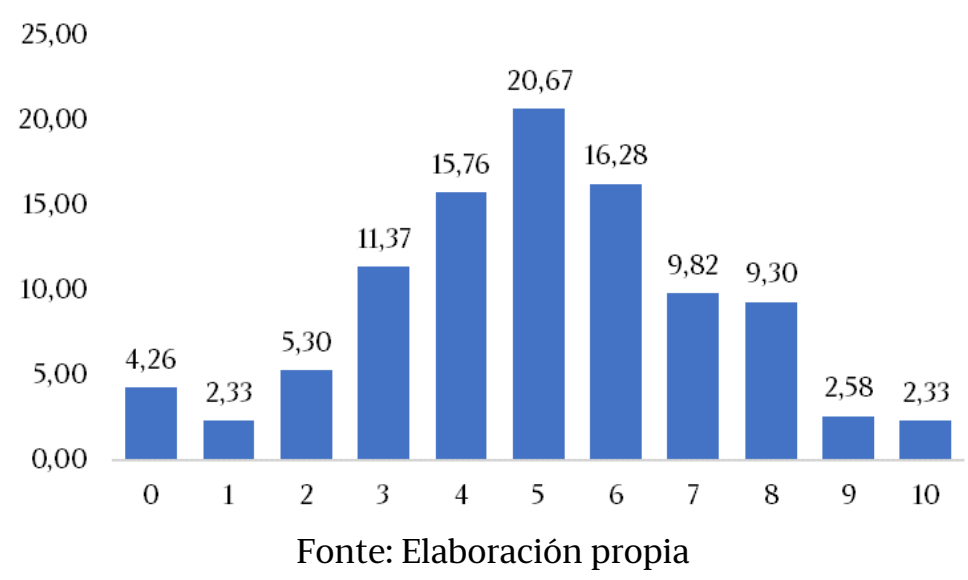

Esta variable foi codificada de novo para convertela nunha variable nominal e desta forma poder facilitar a súa interpretación. Cómpre lembrar que na escala 
utilizada no cuestionario emprégase o 0 como valor mínimo e que implicaría que a oferta se considera moi escasa e 10 que a oferta é moi abundante. A recodificación aplicada foi: de 0 a 3 como baixa, de 4 a 6 media e de 7 a 10 valoración alta.

Os cruzamentos da variable creada mostran diferenzas significativas coas variables independentes de formación, ingresos, nivel de equipamento e subscrición a algunha plataforma dixital, das cales se amosan os resultados a continuación.

Na seguinte gráfica móstranse os datos da variable mencionada segundo o nivel de estudos e pódese comprobar que a medida que aumenta o nivel de estudos máis baixa é a valoración da oferta cultural en galego para menores de 16 anos. Así, pódese comprobar que un 30,80\% das persoas con estudos universitarios superiores lle outorgan unha puntuación baixa a esta oferta. Pola contra, un $31,68 \%$ das persoas con estudos primarios ou similares mostra un interese alto pola oferta cultural en galego para menores de 16 anos. De todos os xeitos, a resposta máis frecuente é a dun interese medio, que se corresponde cunha valoración de entre 4 a 6 puntos. Cómpre salientar a alta porcentaxe de abstención nesta resposta, sobre todo no caso das persoas sen estudos, un 53,85\% destas non sabe ou non contesta.

\section{Valoración da oferta cultural en galego para menores de 16 anos segundo o nivel de estudos (Valores medios nunha escala 0-10)}

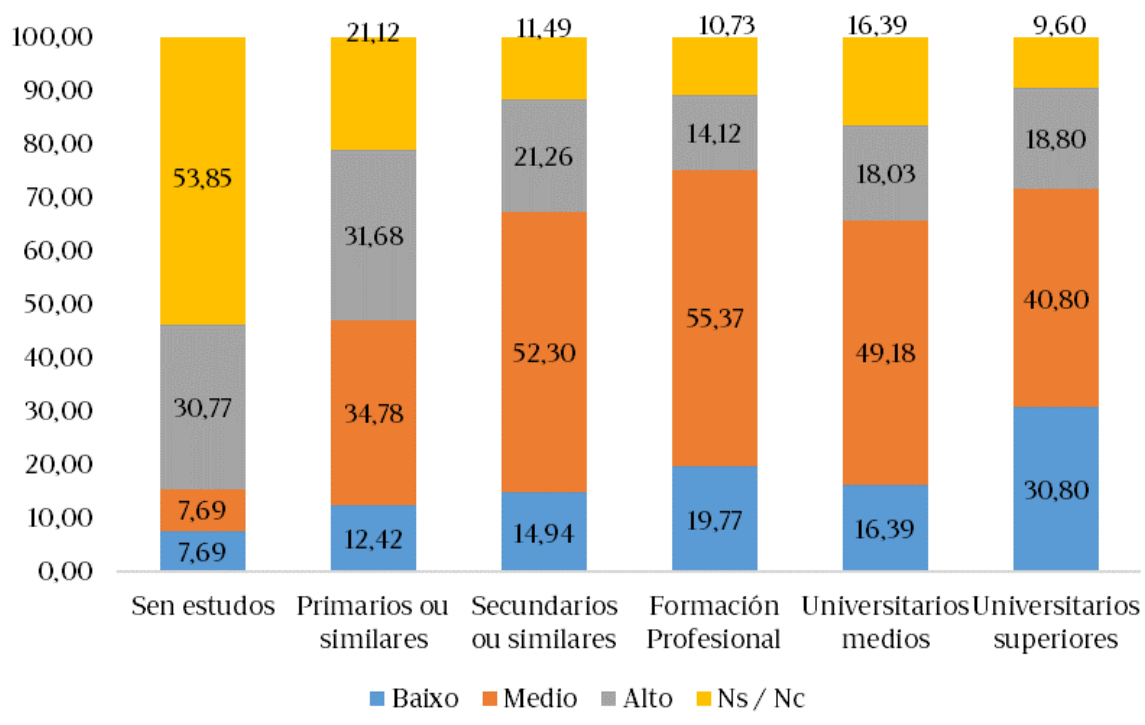

Fonte: Elaboración propia

Ao analizar a influencia do nivel de ingresos do fogar, constátase que a tendencia é moi similar ao caso anterior da variable de nivel de estudos, é dicir, o nivel de ingresos no fogar é inversamente proporcional á valoración da oferta cultural en galego. De feito, un $26,6 \%$ das persoas coa renda máis alta avalíana como baixa, 6,6 puntos porcentuais por riba das que ingresan entre $1.000 \mathrm{e}$ 2.000 euros e $13,6 \%$ con respecto aos fogares con menos ingresos, como se explica na seguinte táboa. 


\section{Valoración do nivel da oferta cultural en galego para menores de 16 anos segundo os ingresos do fogar (Valores medios nunha escala 0-10)}

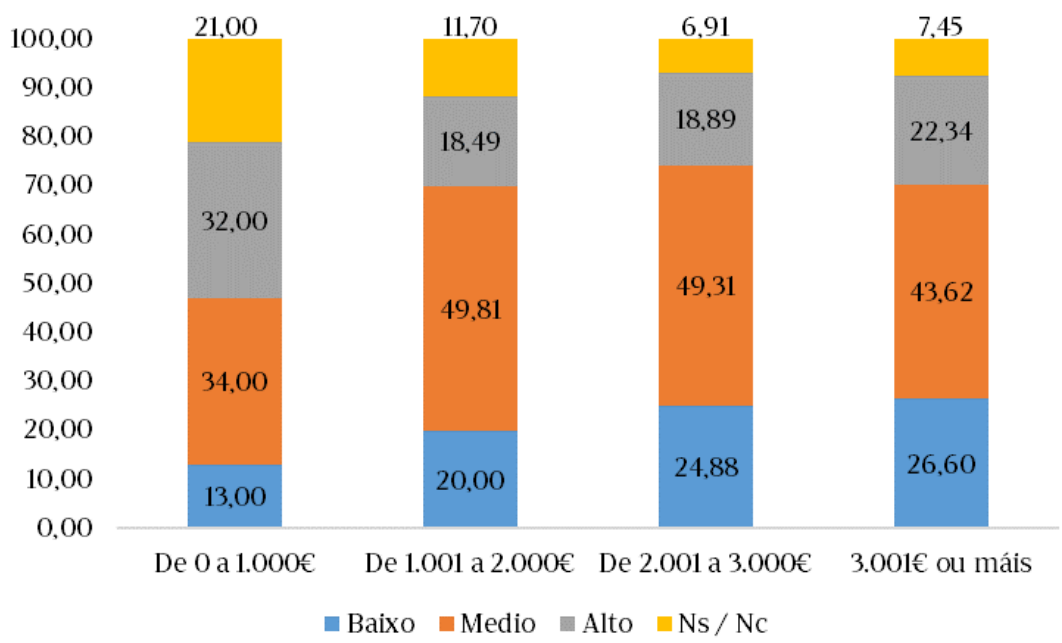

Fonte: Elaboración propia

Por último, analízanse os datos da variable de valoración da oferta cultural en galego para menores de 16 anos en relación co grao de equipamento cultural no fogar e a de subscrición ou non a plataformas dixitais de contidos culturais. Como xa se explicou anteriormente, estas dúas variables están moi relacionadas e, polo tanto, ofrecen resultados moi semellantes. Aquelas persoas que contan cun nivel alto de equipamento cultural no seu fogar e están subscritas a plataformas dixitais ofrecen datos moi parecidos. De feito, canto máis alto sexa o nivel de equipamento cultural no fogar, máis baixa é a valoración desta oferta cultural. Aínda así, máis da metade das persoas cun grao alto de equipamento no fogar e que están subscritas a plataformas dixitais de contidos culturais teñen unha valoración media desta oferta, como se pode observar nas seguintes gráficas.

Valoración da oferta cultural en galego para menores de 16 anos segundo o nivel de equipamento do fogar (Valores medios nunha escala 0-10)

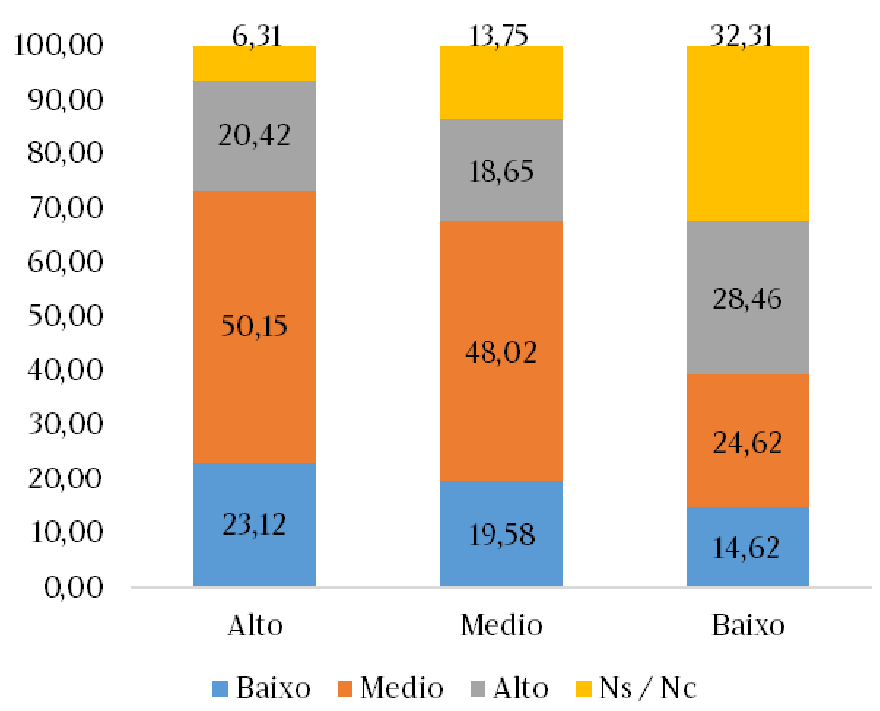

Fonte: Elaboración propia 
Valoración da oferta cultural en galego para menores de 16 anos segundo a subscrición ou non a plataformas dixitais de contidos culturais (Valores medios nunha escala 0-10)

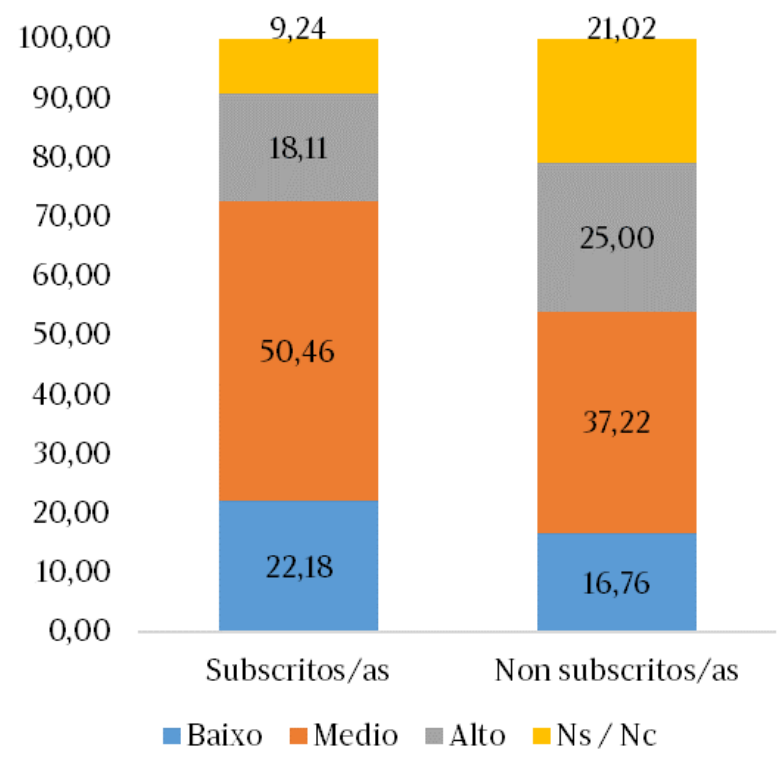

Fonte: Elaboración propia 


\section{AVALIACIÓN DA OFERTA CULTURAL EN GALEGO PARA ME- NORES DE 16 ANOS}

No presente apartado estúdase a abundancia ou carencia de oferta cultural en galego para menores de 16 anos nas seguintes dimensións:

- Libros: en papel e dixital de temáticas diversas.

- Espectáculos: teatro, danza, ballet, ópera, circo, contacontos, monicreques, maxia etc.

- Cine en sala: en versión orixinal, subtitulado, dobrado e producido en galego, animación en galego etc.

- Música: tradicional, moderna, infantil etc.

- Museos e exposicións: artes visuais, históricos, xacementos, ciencias naturais.

- Televisión: series, películas, programas educativos e lúdicos etc.

- Plataformas e contidos audiovisuais: series, televisión á carta, canles de vídeo, cine etc.

- Xogos: xogos de mesa, tradicionais, xoguetes interactivos, videoxogos etc.

Ás persoas entrevistadas pedíuselles que valorasen se a oferta en cada produto ou servizo contemplado é suficiente ou non. Aos que consideran que a oferta é insuficiente pedíuselles que concretasen, nunha pregunta aberta e múltiple, que tipo de contidos son os que botan en falta.

En xeral, a maioría das persoas enquisadas consideran que a oferta de contidos culturais en galego para a infancia é escasa, salvo no caso dos libros, que un $56,44 \%$ estima suficiente. No seguinte gráfico realízase unha comparativa sobre a suficiencia ou insuficiencia destes contidos culturais, co fin de obter unha visión de conxunto. 


\section{Porcentaxe de persoas segundo a súa valoración da oferta cultural en galego} para menores de 16 anos segundo os contidos

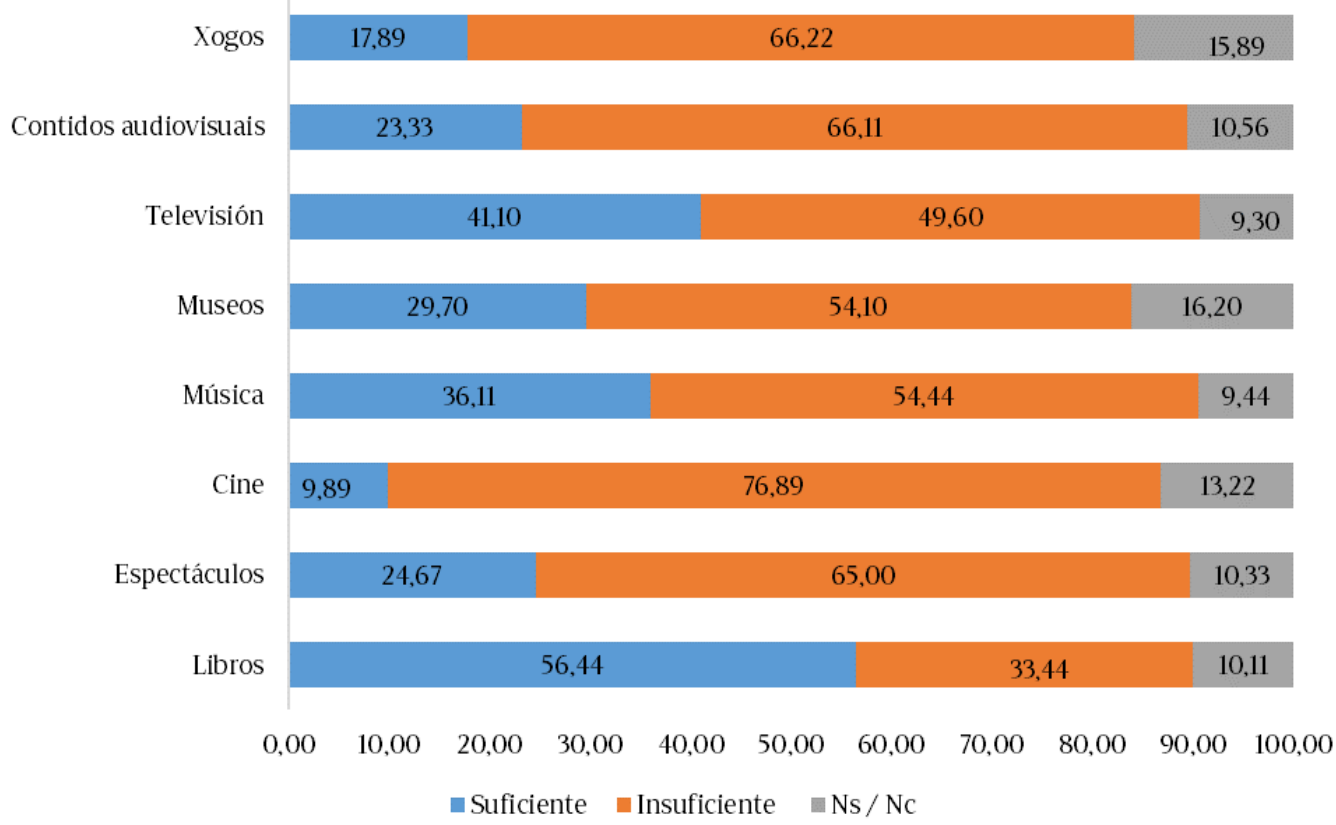

Fonte: Elaboración propia

A continuación analizarase cada contido cultural por separado, de tal xeito que, por unha banda,mostraranse as frecuencias globais e, por outra, o cruzamento con aquelas variables que resultaron ter influencia nos resultados.

\subsection{LIBROS}

Se se considera especificamente a oferta de libros en galego para menores de 16 anos, máis da metade da persoas entrevistadas, concretamente un 56,4\%, consideran que é suficiente.

Oferta de libros en galego para menores de 16 anos

\begin{tabular}{lcc} 
& Total & Porcentaxe \\
\hline Suficiente & 508 & 56,4 \\
Insuficiente & 301 & 33,4 \\
Ns/Nc & 91 & 10,1 \\
\hline
\end{tabular}

Fonte: Elaboración propia

A continuación preséntase a relación coas variables independentes que achegaron diferenzas nos seus niveis ao cruzar coa oferta de libros en galego para menores de 16 anos. Estas variables son: se hai ou non menores no fogar, a lingua habitual de expresión, ocupación das persoas entrevistadas, o nivel de equipamento cultural no fogar e se están subscritos ou non a algunha plataforma do contidos culturais.

Ao cuestionar a oferta de libros en galego segundo haxa ou non menores no fogar, obsérvase que nos dous grupos hai unha porcentaxe similar de persoas 
que din que é insuficiente. Porén, nos fogares onde hai menores, o 65,3\% das persoas afirma que a oferta de libros é suficiente, fronte ao 49,3\% dos fogares onde non os hai. Estes resultados compénsanse co gran número de persoas entrevistadas deste último grupo que non responden, probablemente por descoñecemento.

\section{Oferta de libros en galego para menores de 16 anos segundo se hai menores de 16 anos no fogar ou non}

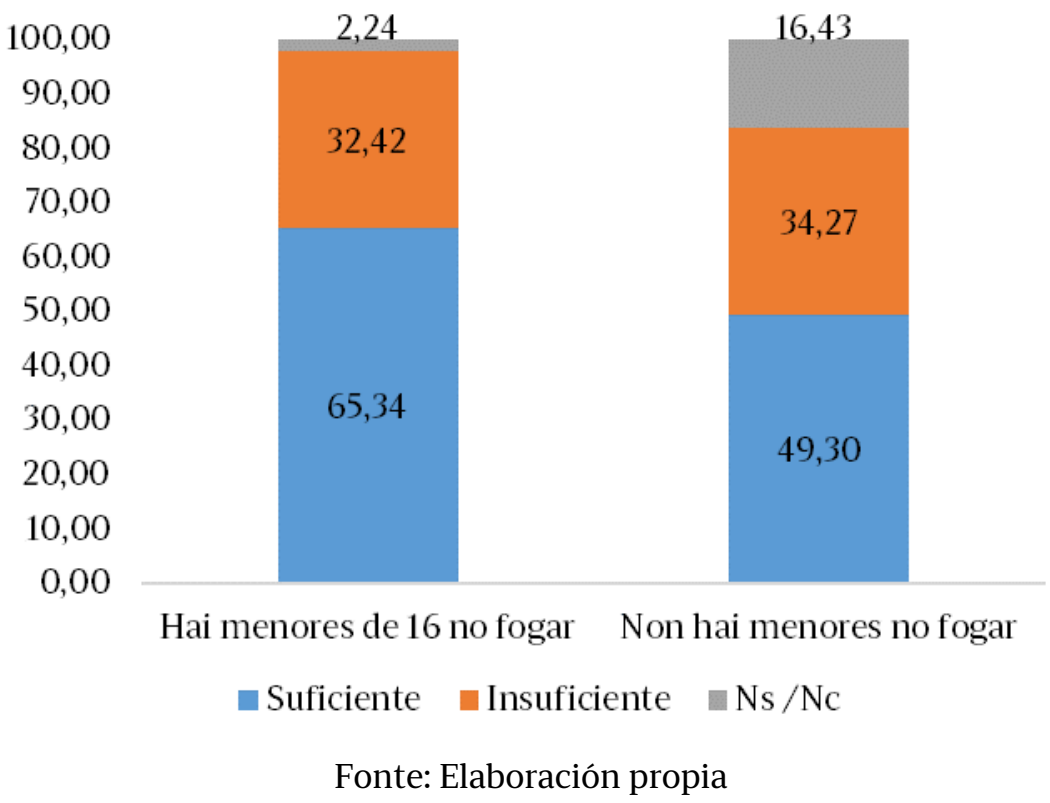

Ao relacionar a variable libros en galego para menores de 16 anos segundo a lingua habitual de expresión das persoas entrevistadas, obsérvase que o grupo cuxa lingua de expresión habitual é só o galego é o que demanda máis libros nesta lingua para menores en comparación co resto, xa que case a metade deste grupo (un 40,82\%) considera que a oferta de libros en galego para menores de 16 anos é insuficiente. Porén, para as persoas monolingües en castelán a oferta destes produtos culturais é bastante satisfactoria: o 57,56\% considera que é suficiente. Para os grupos de persoas bilingües a proporción é bastante semellante, aínda que son as persoas que falan máis galego que castelán as que consideran, unha vez máis, que a oferta de libros en galego para menores de 16 anos é escasa. 
Oferta de libros en galego para menores de 16 anos segundo a lingua habitual de expresión

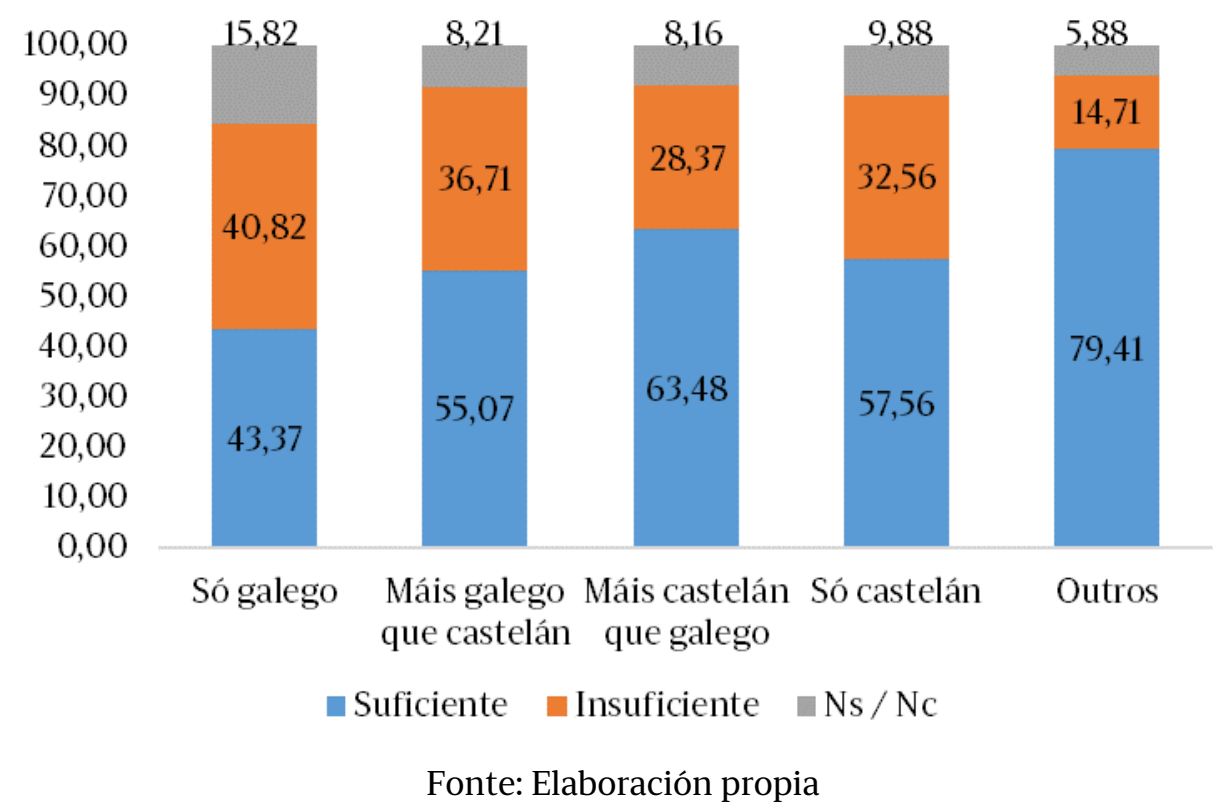

Se se ten en conta a ocupación das persoas entrevistadas, os datos revelan que son os estudantes os que están máis satisfeitos coa oferta de libros en galego para menores de 16 anos, xa que un 74,42\% deste grupo declara que este tipo de contido cultural é suficiente. No outro extremo está o grupo de xubilados e pensionistas, xa que tan só un $44,55 \%$ deles considera que a oferta de libros en galego é suficiente.

\section{Oferta de libros en galego para menores de 16 anos segundo a ocupación}

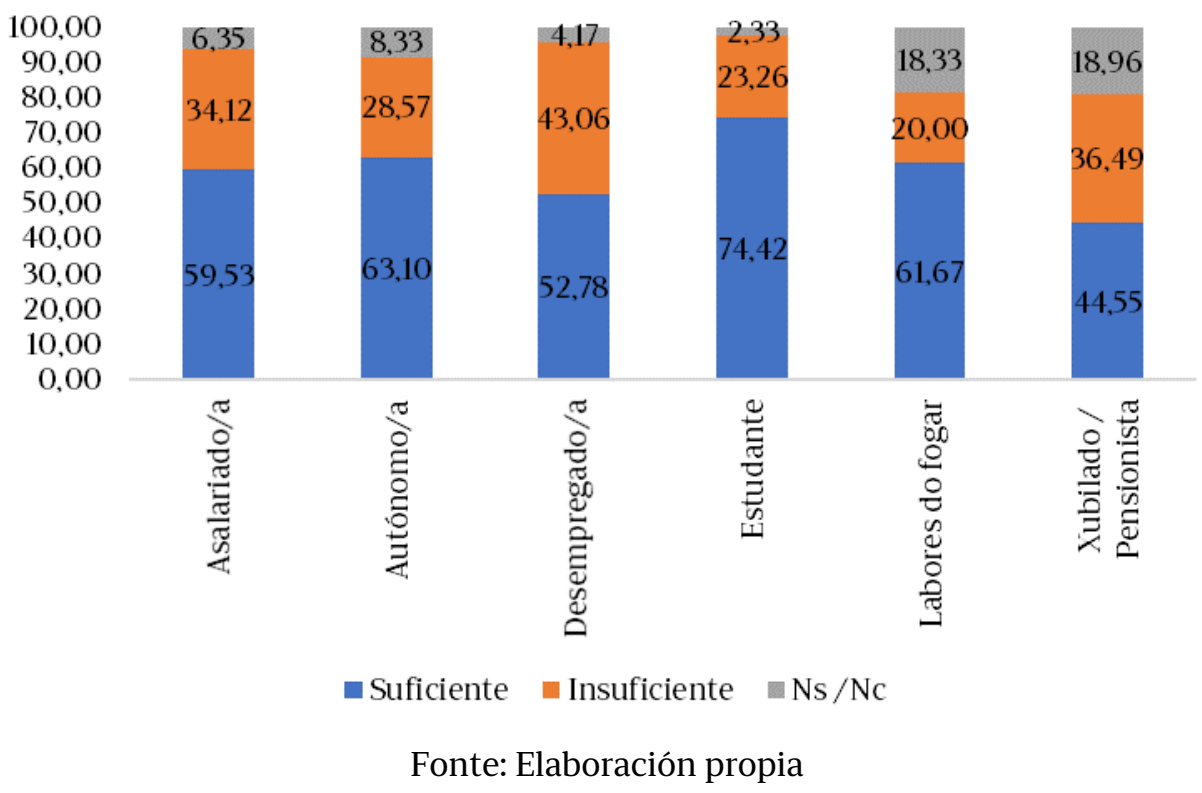

Nas seguintes táboas analízase a demanda de libros en galego para menores de 16 segundo o nivel de equipamento cultural que hai no fogar e a subscrición ou non a plataformas dixitais de contidos culturais.

Como se pode observar, un 65,47\% das persoas cun nivel alto de equipamento cultural no seu fogar considera que a oferta de libros en galego para menores 
de 16 anos é suficiente, case 14 puntos porcentuais por riba das que contan cun nivel medio e máis de 15 con respecto ás que teñen un baixo nivel de equipamento.

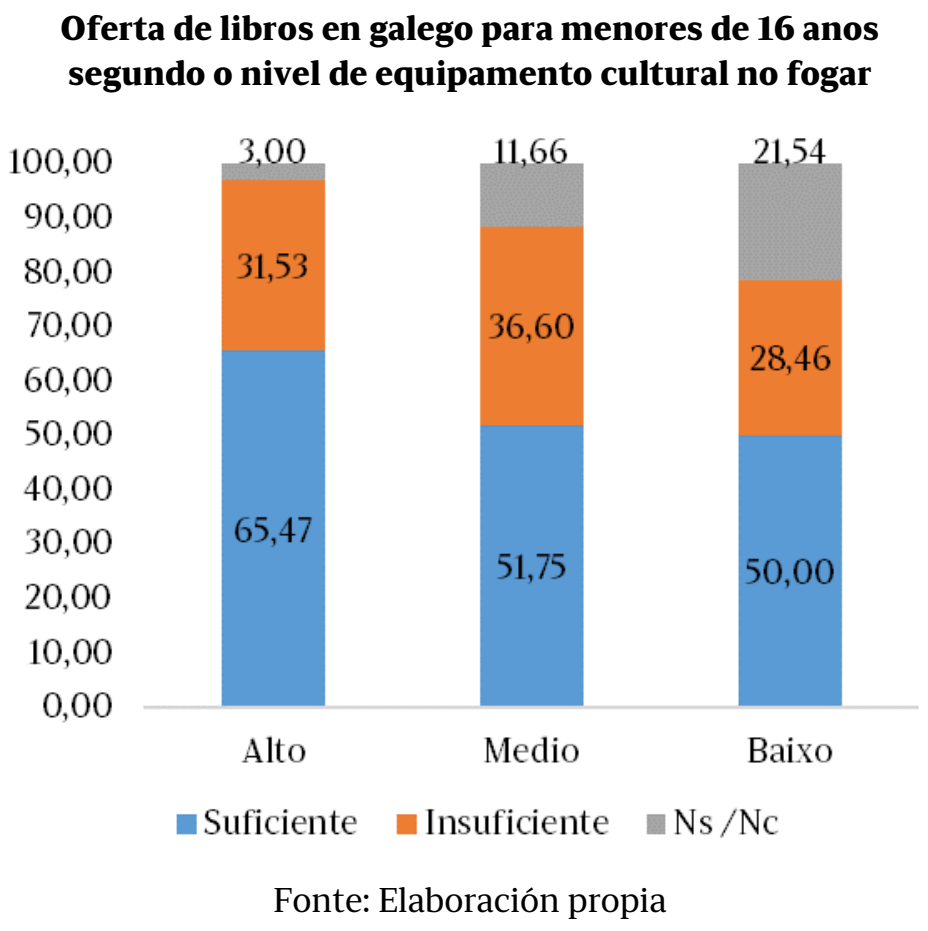

Os resultados son moi similares no cruzamento coa variable de subscrición a plataformas dixitais de contidos culturais. Para máis do $62 \%$ das persoas subscritas a plataformas dixitais, a oferta de libros en galego é suficiente, máis de 14 puntos porcentuais por riba das que non contan con ningunha subscrición.

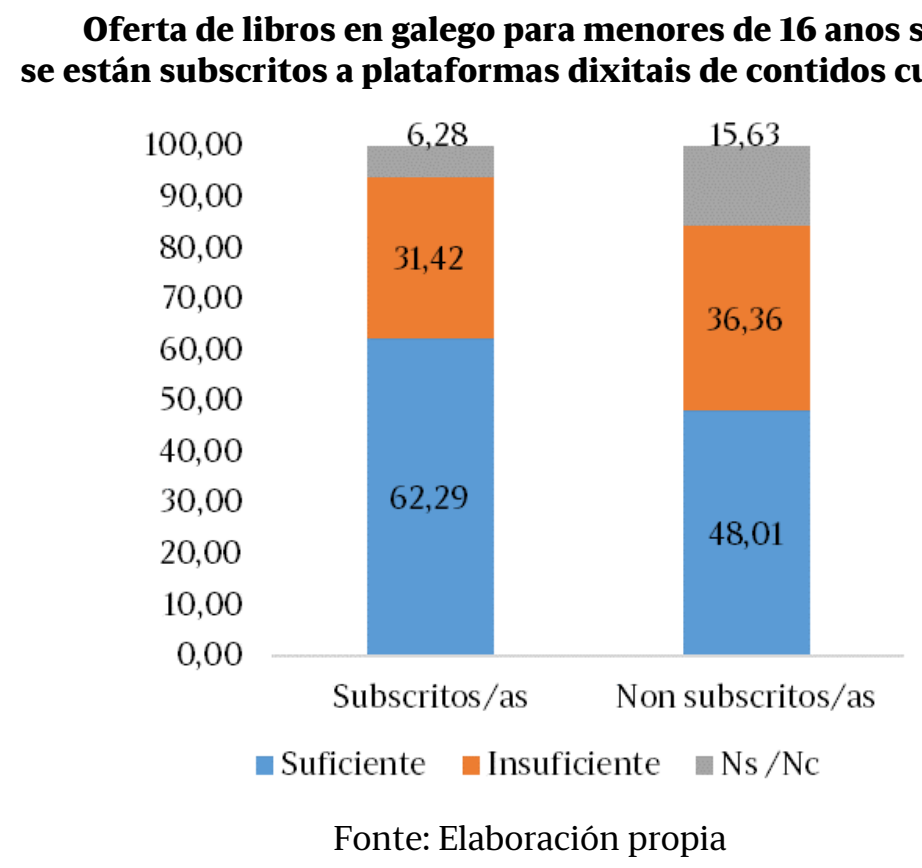

Dentro da categoría de contidos culturais de libros, quíxose indagar sobre o formato de libros en galego para menores de 16 anos que botan máis en falta as persoas que consideran que a oferta é insuficiente. Os libros en formato papel son os que máis se botan en falta nunha porcentaxe dun $43,52 \%$. Porén, a cate- 
goría de libros dixitais é mencionada polo 9,63\% das persoas enquisadas que consideran insuficiente a oferta de libros en galego para os nenos e nenas.

Oferta de libros en galego para menores de 16 anos segundo os formatos máis demandados para as persoas que consideran a oferta insuficiente

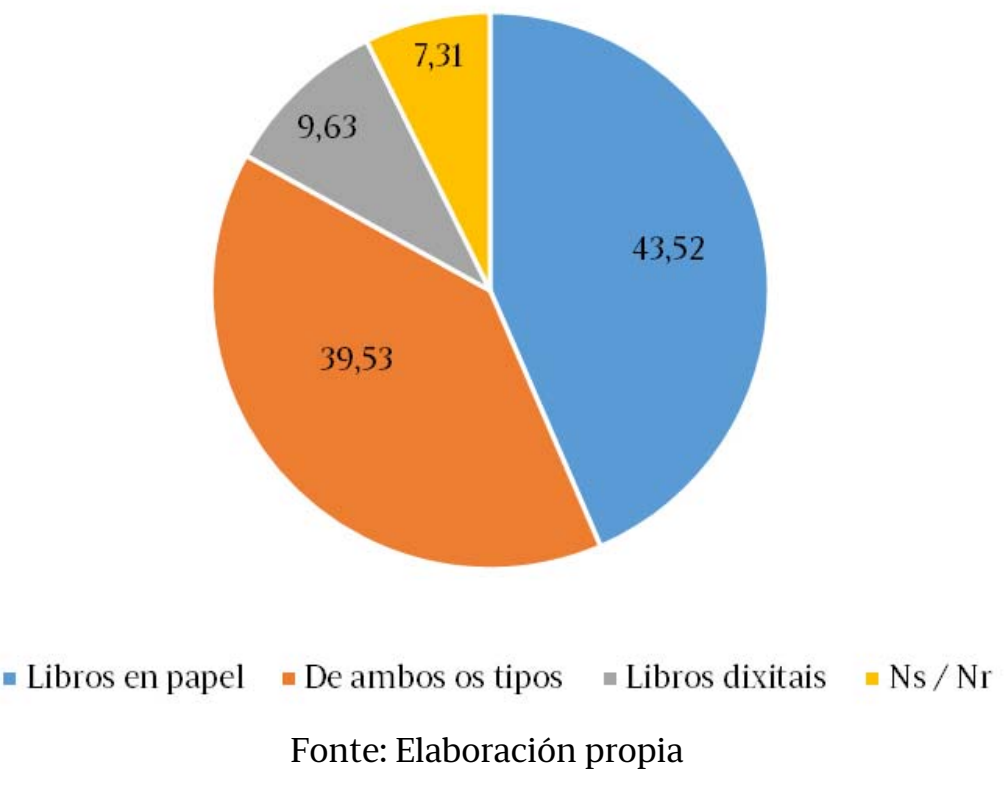

Preguntóuselles tamén ás persoas enquisadas que consideran insuficiente a oferta de libros en galego, a tipoloxía de libros que botaban en falta ou que, segundo a súa opinión, eran máis escasos.

Segundo a temática dos libros que se botan en falta, un 20,7\% das persoas entrevistadas demandan libros de todo tipo. A seguinte clase de libros que máis se solicita é a de temática divulgativa/científica, pero a case 13 puntos de distancia do resultado anterior. Cómpre subliñar que esta pregunta conta cunha alta porcentaxe de respostas "Ns/Nc" (44,4\%). 
Temática de libros en galego para menores máis demandadas segundo se considere a oferta suficiente ou insuficiente

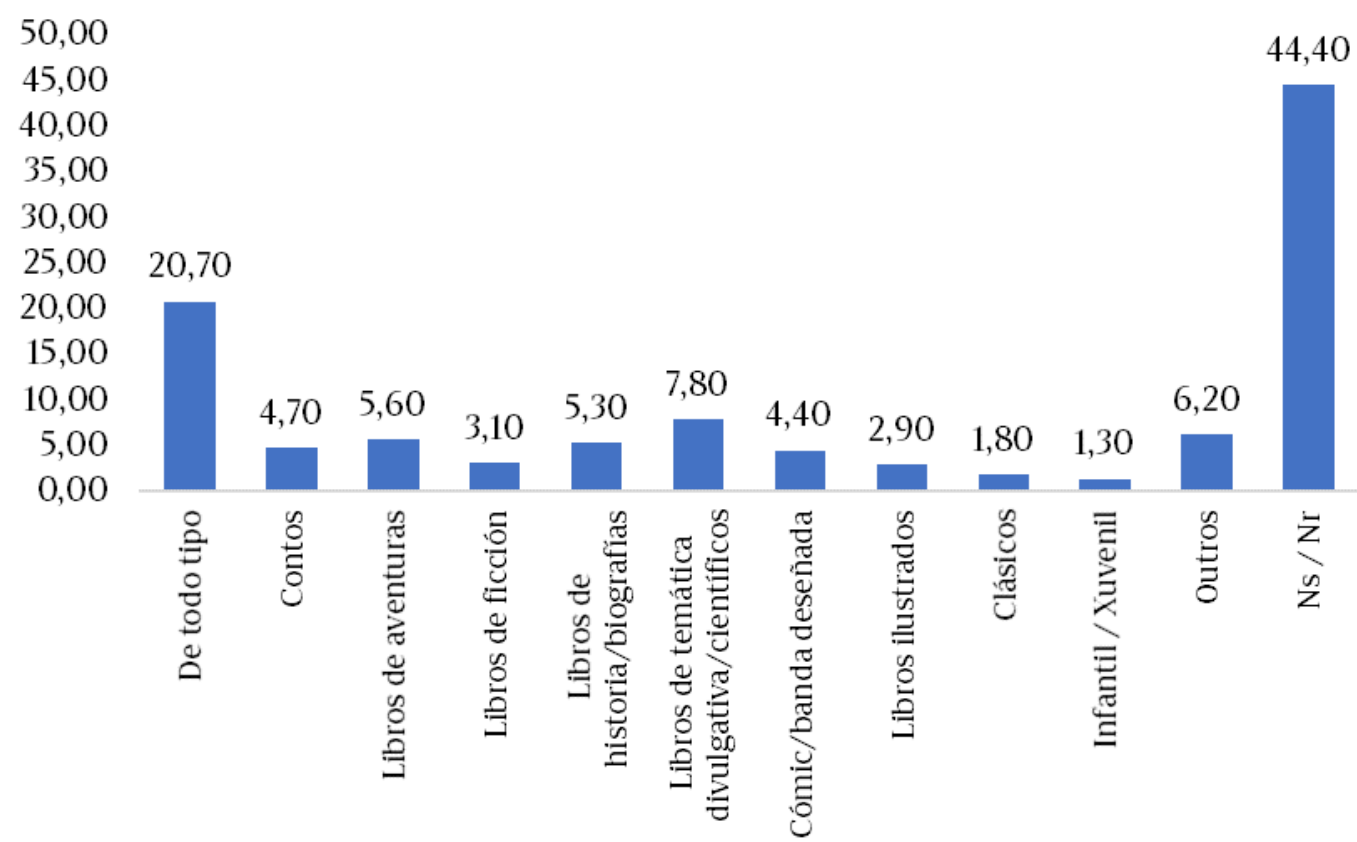

Fonte: Elaboración propia

\subsection{ESPECTÁCULOS}

Nesta sección analízase a oferta de espectáculos en galego para menores de 16 anos, entre os que se inclúen teatro, ópera, ballet, circo ou maxia. Coma no caso anterior, o obxectivo é analizar se as propostas deste tipo de espectáculos se consideran suficientes ou non. Dos datos que se desprenden da enquisa realizada, pódese comprobar na seguinte táboa que unha ampla maioría das persoas entrevistadas (un 65\%) considera que en Galicia a oferta de espectáculos de contido cultural en galego para menores de 16 anos é insuficiente.

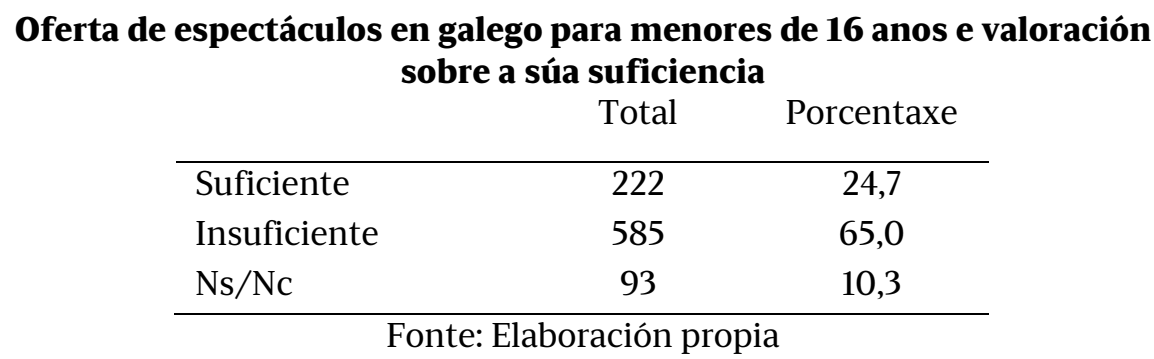

Ao cruzar estes datos coas variables independentes, aquelas cuxos resultados son significativos foron as de lingua habitual de expresión, ocupación, hábitat e contorno de residencia.

Se se analizan estes datos por lingua habitual de expresión da persoa entrevistada, pódese comprobar na seguinte gráfica que son as persoas bilingües con predominio do uso do galego $(73,91 \%)$ e as monolingües en galego $(63,27 \%)$ as que máis demandan espectáculos nesta lingua para menores de 16 anos. As persoas monolingües en castelán son as que mostran menor interese neste aspecto, 
xa que hai unha diferenza de 5,2 puntos porcentuais con respecto ás monolingües en galego. Por último, cómpre salientar que as bilingües con predominio do uso do galego mostran un comportamento case idéntico ás monolingües, con tan só 0,5 puntos porcentuais de diferenza.

Oferta de espectáculos en galego para menores de 16 anos por lingua habitual de expresión

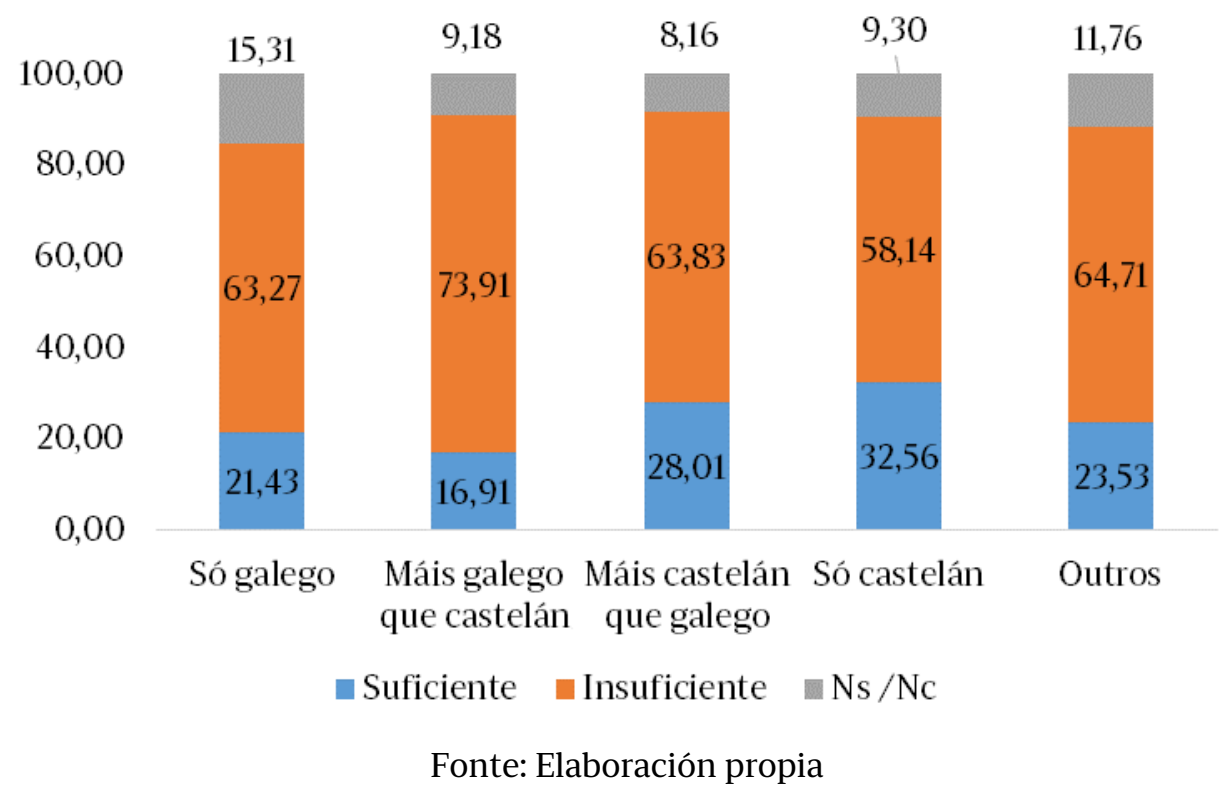

Por ocupación, cómpre destacar que, ao igual ca no caso dos libros, son os estudantes, en proporción, os que consideran que a oferta de espectáculos en galego para menores de 16 anos é suficiente, concretamente un 37,21\%, fronte aos xubilados e pensionistas (18,48\%).

\section{Oferta de espectáculos en galego para menores de 16 anos por ocupación}

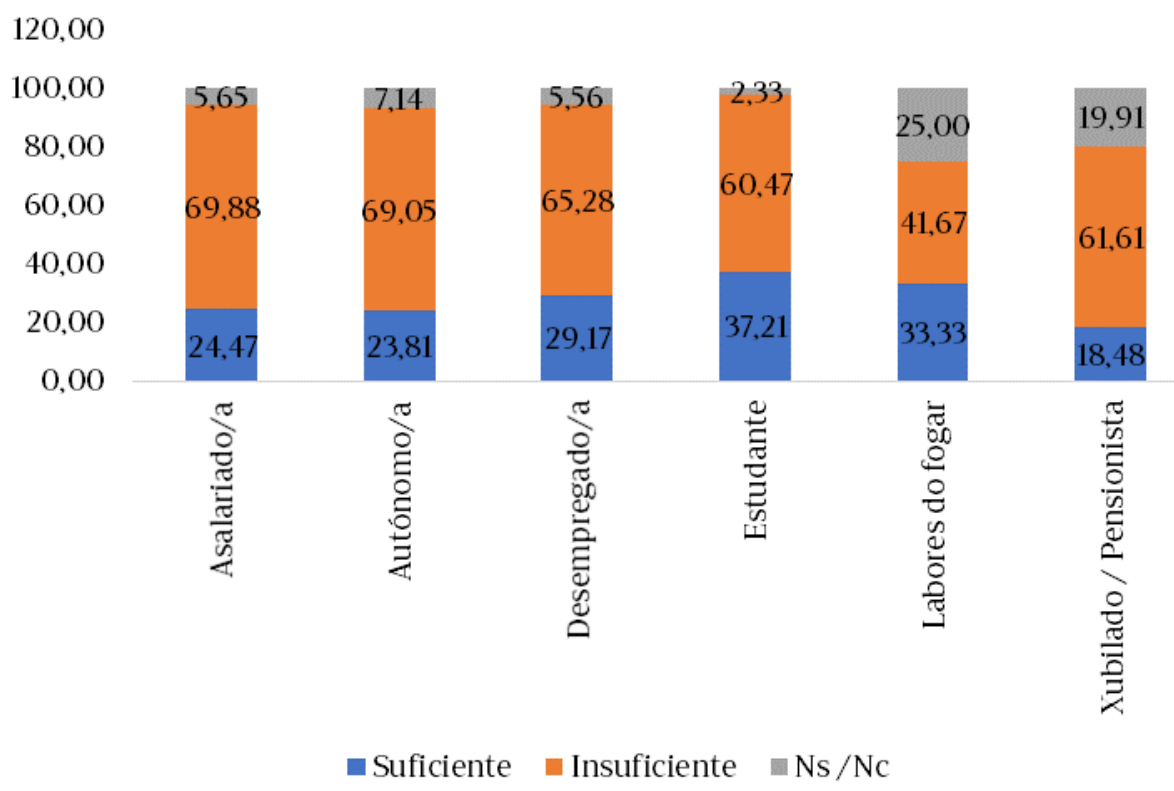

Fonte: Elaboración propia

Con respecto ao lugar de residencia, móstrase nas seguintes táboas que canto menor é un núcleo de poboación e, polo tanto, un contorno máis rural, percí- 
bese menor oferta de espectáculos en galego para menores de 16 anos. No caso das poboacións máis pequenas, a porcentaxe de persoas que consideran a oferta insuficiente supera o 70\%. Por outra banda, é nas vilas de tamaño medio (entre 20.000 e 50.000 habitantes) onde se considera en maior proporción que a oferta deste tipo de contidos culturais é suficiente (arredor dun 31\%).

\section{Oferta de espectáculos en galego para menores de 16 anos por hábitat de residencia}

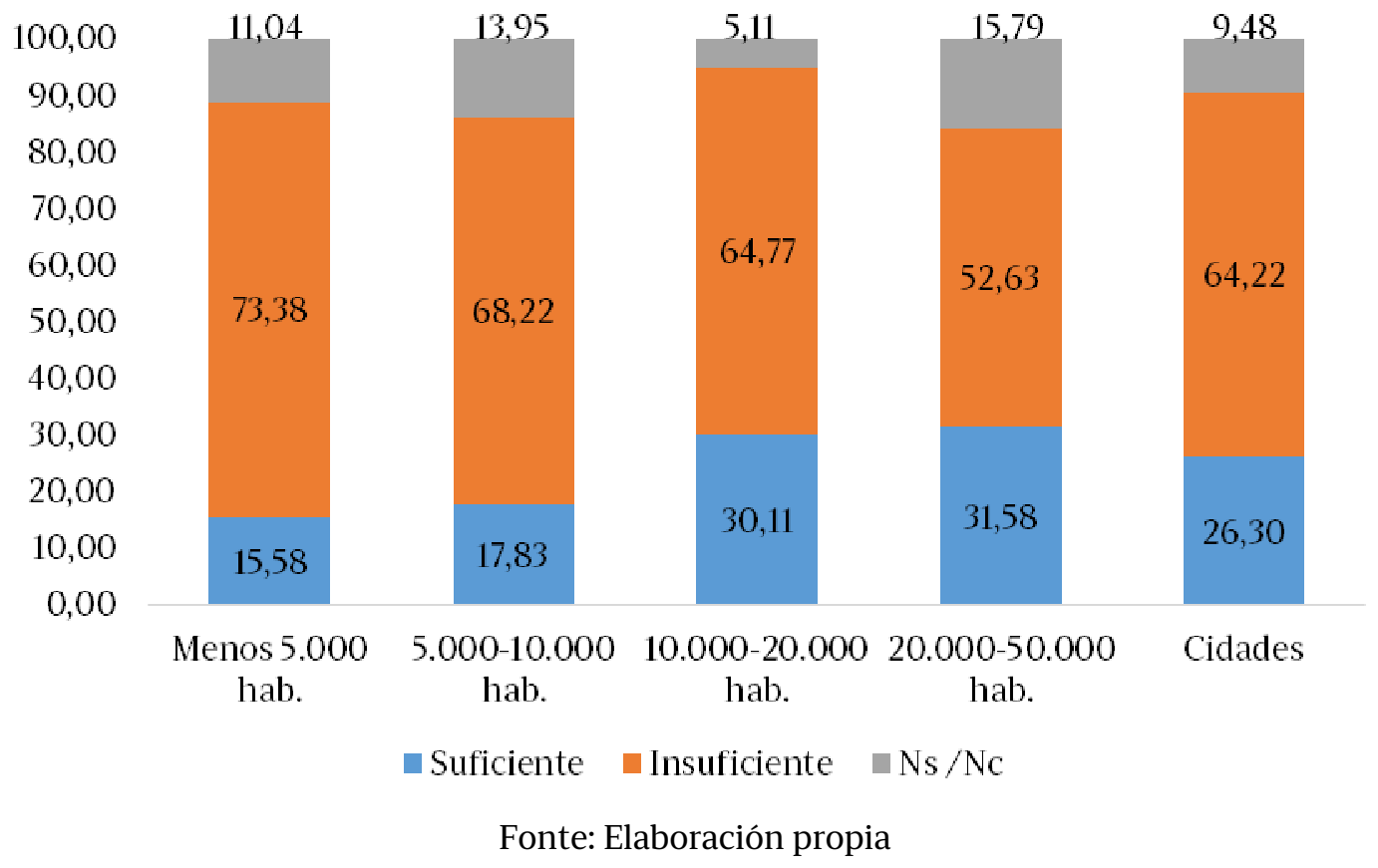

\section{Oferta de espectáculos en galego para menores de 16 anos por tipoloxía de contorno de residencia}

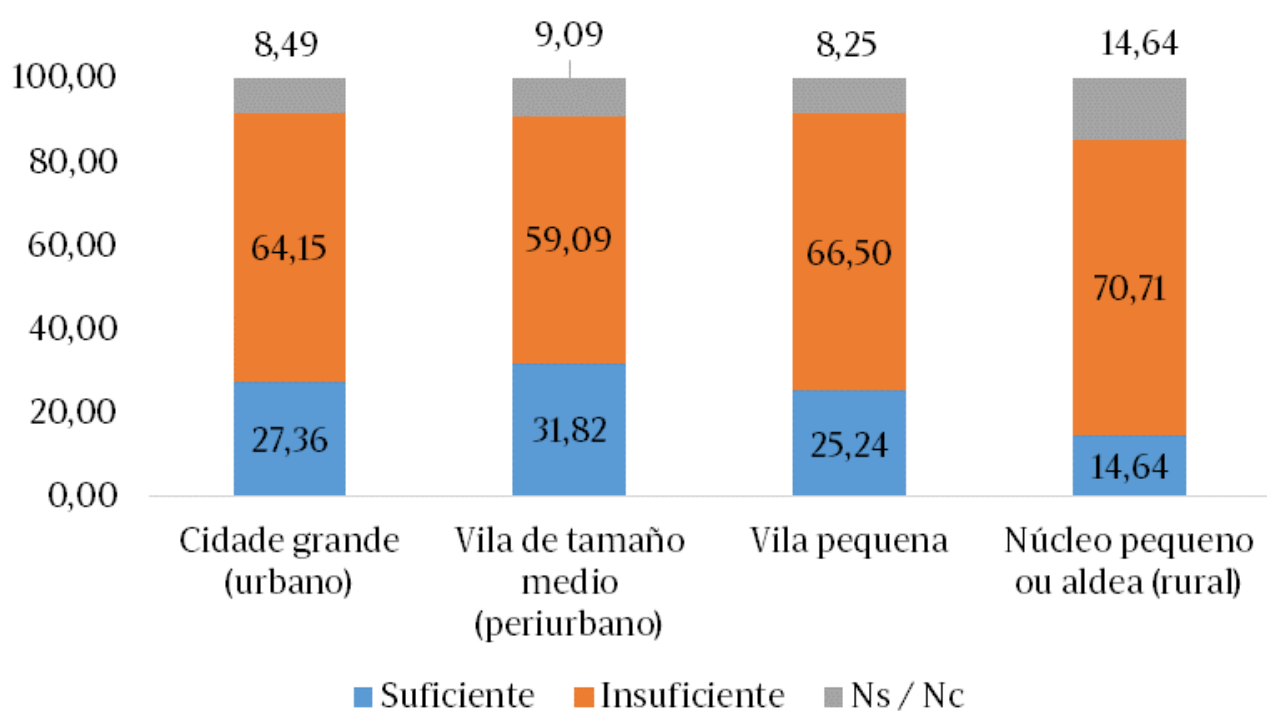

Fonte: Elaboración propia

Ademais de preguntarlles ás persoas entrevistadas se consideraban suficiente ou insuficiente a oferta de espectáculos en galego para menores de 16 anos, tamén se quixo indagar na tipoloxía de espectáculos que pensaban que era máis escasa para a rapazada. Entre as persoas que consideran insuficiente a oferta de 
espectáculos en galego, un 29,6\% considera que faltan espectáculos de todo tipo en galego.

Verifícase que é o teatro o tipo de espectáculos culturais en galego para menores de 16 anos que máis botan en falta as persoas que consideraban insuficiente a oferta: concretamente un $45,39 \%$ das persoas entrevistadas demandan este tipo de eventos culturais e o seguinte é o de contacontos $(13,82 \%)$. No outro extremo, o espectáculo menos demandado son os concertos (1,64\%).

Tipoloxía de espectáculos en galego para menores de 16 cuxa oferta segundo as persoas enquisadas é insuficiente

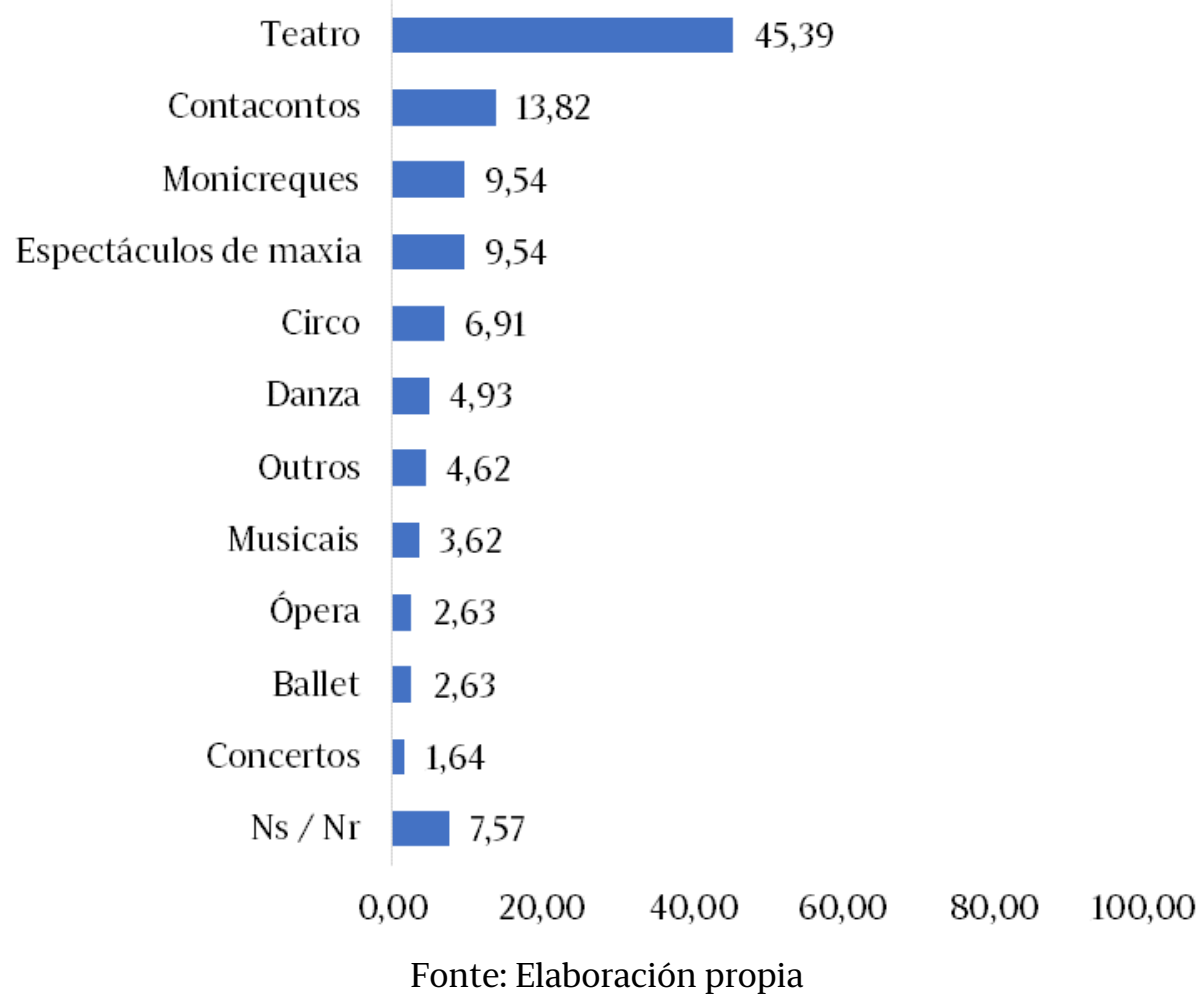




\subsection{CINE EN SALA}

Neste apartado analízase a oferta de cine en sala en galego para menores de 16 anos. Máis de tres cuartas partes das persoas entrevistadas consideran que a oferta deste tipo de contido cultural é insuficiente, o que o sitúa como a actividade cultural menos ofertada de todas as que se estudan neste informe.

\begin{tabular}{lcc} 
Oferta de cine en sala en galego para menores de $\mathbf{1 6}$ ano & Total & Porcentaxe \\
& 89 & 9,9 \\
\hline Suficiente & 585 & 76,9 \\
Insuficiente & 119 & 13,2 \\
Ns/Nc & \\
\hline
\end{tabular}

Fonte: Elaboración propia

Como se fixo nos anteriores apartados referentes ao libro e aos espectáculos, cruzáronse os datos anteriores coas variables que mostran diferenzas significativas para a oferta de cine en sala en galego para menores de 16 anos. Así, atopouse que as variables que achegan resultados diferenciais son as seguintes: idade, formación, ingresos, ocupación, tipoloxía do contorno de residencia, se está subscrito ou non a calquera plataforma de contido cultural e o grao de equipamento cultural no fogar.

Ao cruzar os datos da oferta de cine en sala en galego para menores de 16 anos coa variable de idade, compróbase que canto máis novas son as persoas entrevistadas consideran en maior proporción que a oferta é insuficiente. Así, o $90,91 \%$ das persoas de entre 15 e 29 anos e o 86,83\% de entre 30 e 44 considérana escasa. $O$ treito de idade de maiores de 65 anos é o que rexistra maior porcentaxe de indecisión ou falta de resposta a este respecto, ao non coñeceren a oferta que existe, e tamén a porcentaxe máis baixa de persoas que consideran que a oferta de cine en galego é insuficiente.

oferta de cine en sala en galego para menores de 16 anos por idade

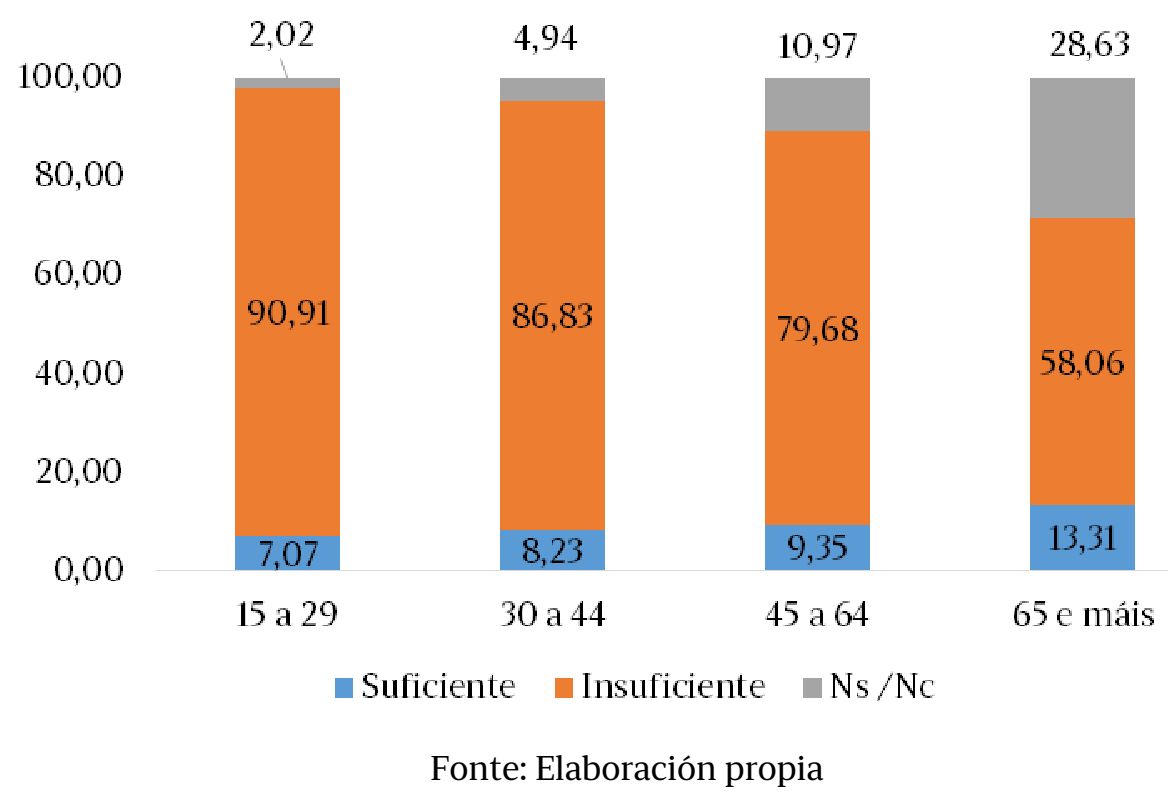


Ao cruzar estes datos por nivel de estudos comprobouse que son as persoas que teñen estudos universitarios, é dicir, o nivel de estudos máis elevado, as que consideran en maior proporción que a oferta de cine en galego para menores de 16 anos é insuficiente. Polo tanto, tal como se pode observar nos datos da seguinte gráfica, canto máis alto é o nivel de estudos, maior demanda hai de cine en galego para menores de 16 anos.

Oferta de cine en sala en galego para menores de 16 anos por nivel de estudos

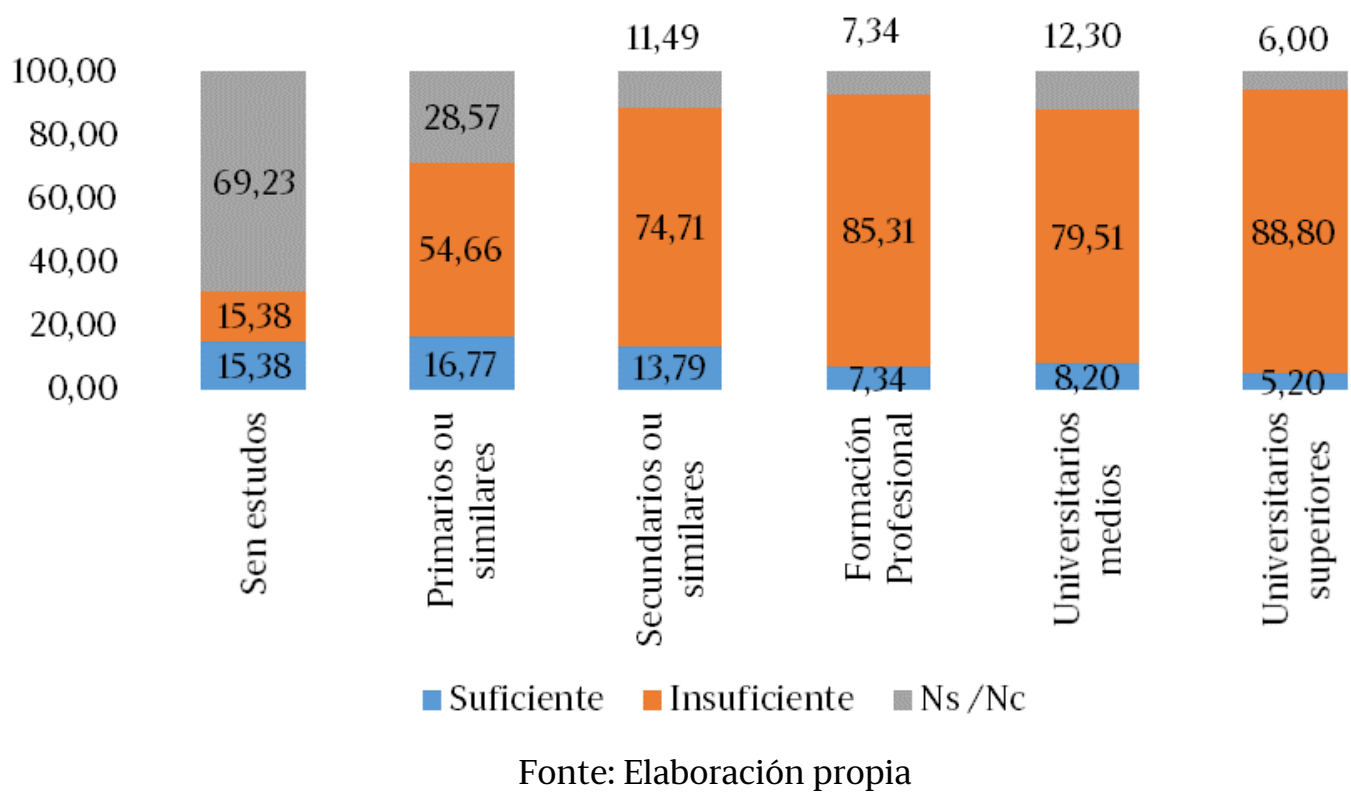

Tal como acontecía co caso dos libros e dos espectáculos, cando se cruzan os datos de oferta de cine en galego para menores de 16 anos coa variable de ocupación, volve ser o grupo dos estudantes o que considera que a oferta é insuficiente, concretamente un $88,4 \%$. Outra tendencia que se pode destacar no caso do cine refírese ao feito de que é o grupo das persoas xubiladas ou pensionistas e o das persoas que se dedican aos labores do fogar as que manifestan nunha proporción importante (26,5\% no primeiro caso e $31,7 \%$ no segundo) descoñecemento sobre a oferta que existe, ou simplemente non responden a esta pregunta. 


\section{Oferta de cine en sala en galego para menores de 16 anos por ocupación}

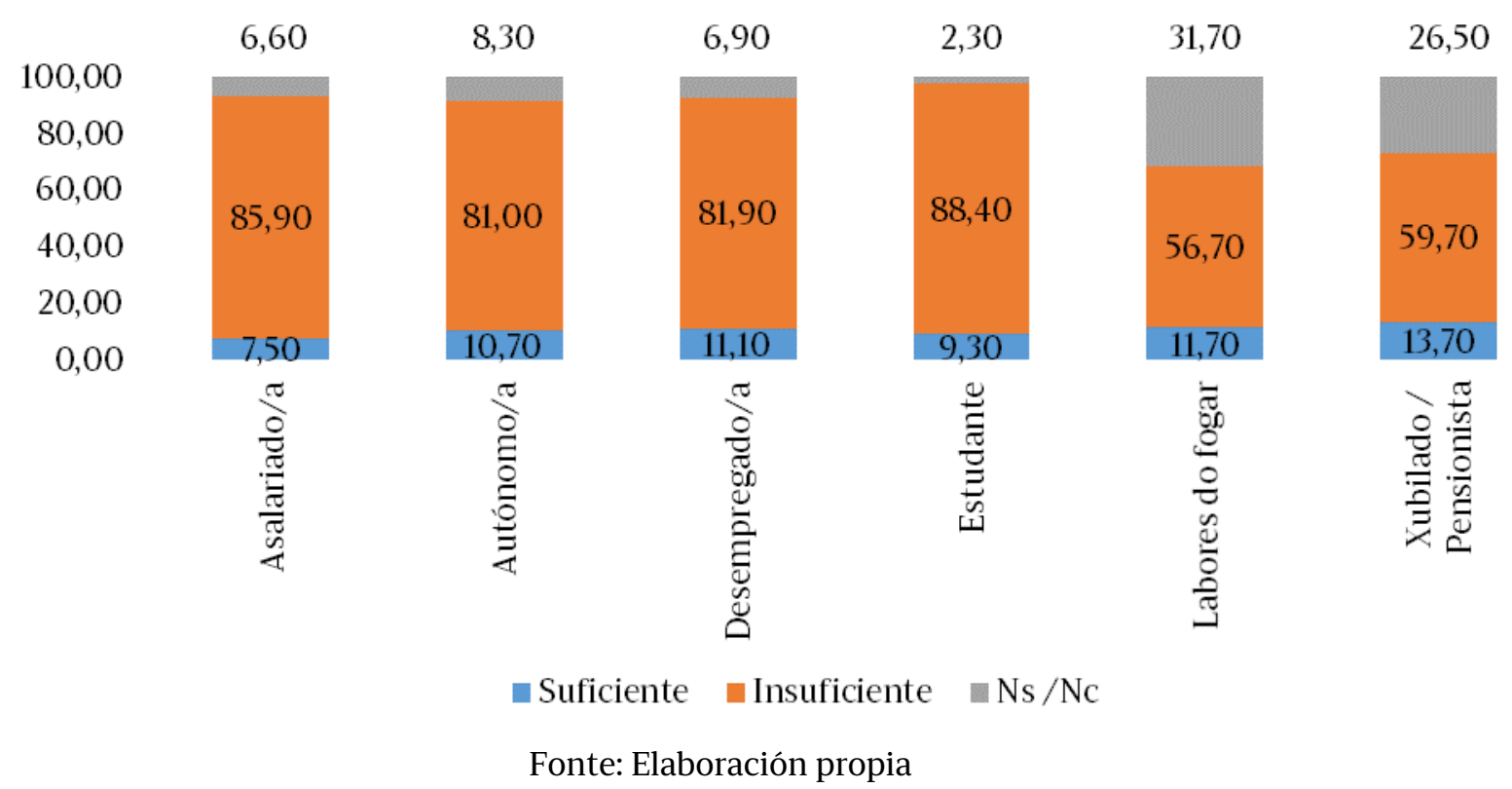

A variable de nivel de ingresos denota que canto máis altos son estes máis escasa se considera a oferta de cine en galego para menores. Así, a porcentaxe de persoas entrevistadas que consideran que esta oferta cultural non abonda medra proporcionalmente a medida que o nivel de ingresos do fogar se incrementa, de tal xeito que o treito de máis ingresos que se inclúe neste informe (máis de 3.001 euros) supera en 32,4 puntos porcentuais ao de menos ingresos (de 0 a 1.000 euros). Ademais, neste último treito de ingresos é onde se rexistra maior porcentaxe de respostas "Non sabe/non contesta” (29\%).

Oferta de cine en sala en galego para menores de 16 anos por nivel de ingresos

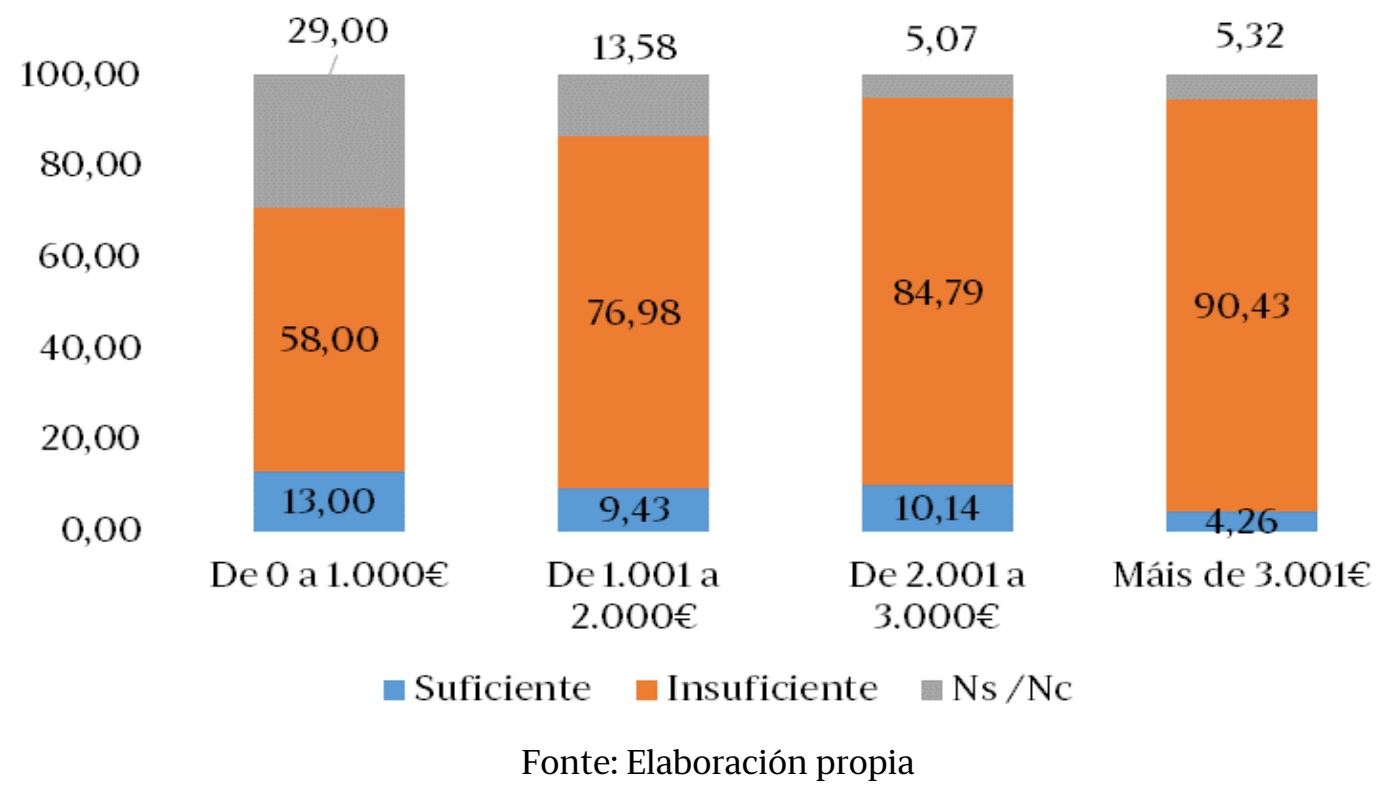

Se se analiza a variable do contorno de residencia, obsérvase que canto máis urbano é o hábitat en que viven as persoas entrevistadas, maior porcentaxe se rexistra de persoas que consideran insuficiente a oferta de cine en sala en galego para menores de 16 anos, concretamente un $82,55 \%$. Os contornos periurbanos 
son que ofrecen a porcentaxe máis alta de persoas que consideran suficiente esta oferta cultural, aínda que segue a ser moi baixa (13,88\%).

\section{Oferta de cine en sala en galego para menores de 16 anos por tipoloxía de contorno de residencia}

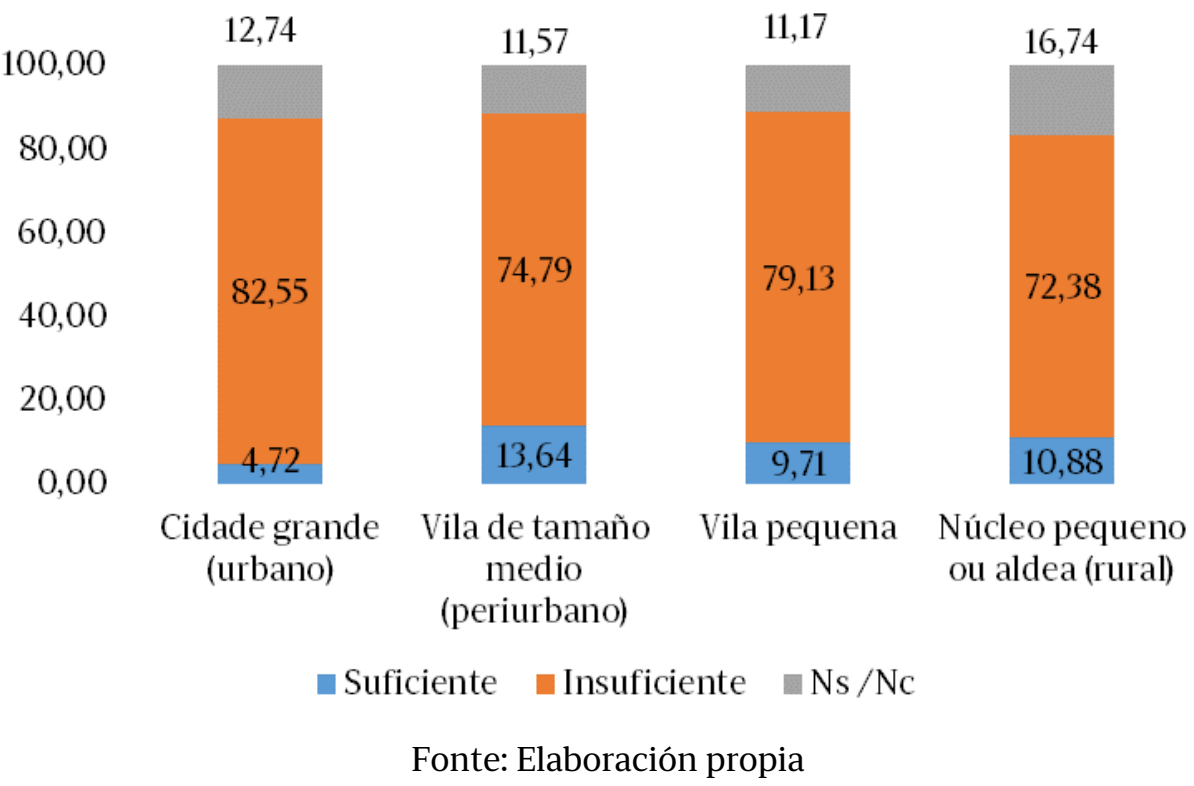

Ao igual que acontecía no caso dos libros, as variables de nivel de equipamento cultural que hai no fogar e a subscrición ou non a plataformas dixitais de contidos culturais están moi relacionades e, polo tanto, ofrecen datos moi similares con respecto á percepción da oferta de cine en sala en galego para menores de 16 anos. Así, como se pode observar, as persoas cun nivel alto de equipamento cultural no seu fogar e as que están subscritas a plataformas de contidos culturais consideran que a oferta de cine en galego para menores de 16 anos é insuficiente. As dúas categorías acadan porcentaxes moi similares, superiores ao $85 \%$.

\section{Oferta de cine en sala en galego para menores de 16 anos por nivel de equipamento cultural no fogar}

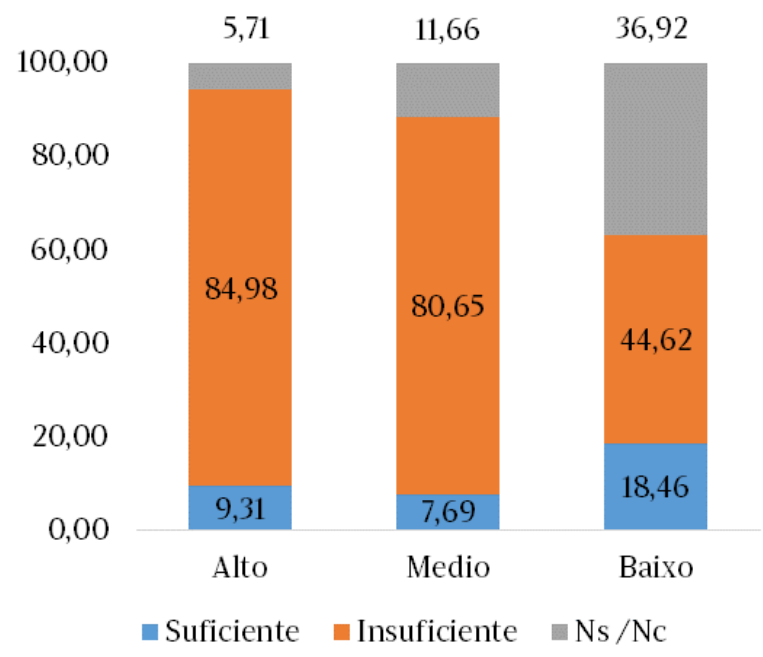

Fonte: Elaboración propia 


\section{Oferta de cine en sala en galego para menores de 16 anos segundo} se están subscritos a plataformas dixitais de contidos culturais

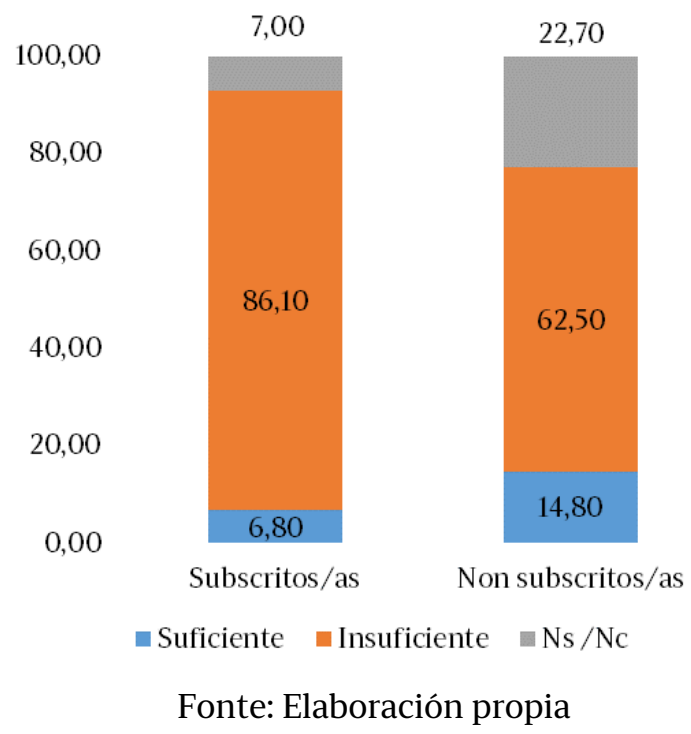

Preguntóuselles ás persoas enquisadas que consideraban insuficiente a oferta de cine en galego para menores de 16 anos, o tipo de cine que botan en falta ou que consideran máis escaso. A partir das respostas, elabórase unha tipoloxía coas seguintes categorías: de todo tipo, cine de animación en galego, cine dobrado ao galego, cine producido en galego, cine en versión orixinal subtitulada en galego, infantil/xuvenil, outros.

Con respecto ao grupo que considera que a oferta é insuficiente, o $44,1 \%$ bota en falta, en primeiro lugar, todo tipo de cine en galego e, en segundo, cunha diferenza de máis de vinte puntos porcentuais, menciónase o cine de animación en galego.

Tipoloxía de cine en galego para menores de 16 anos que botan en falta as persoas enquisadas que consideran escasa esta oferta (Resposta múltiple)
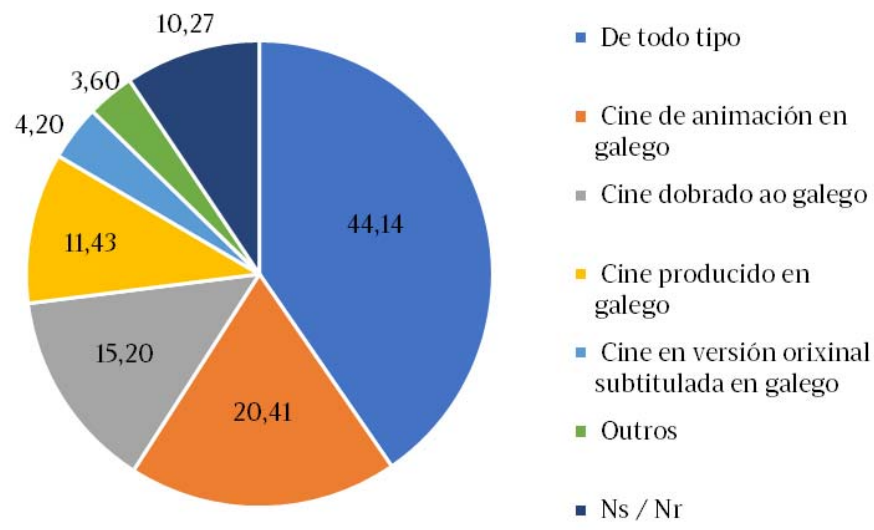

Fonte: Elaboración propia 


\subsection{MÚSICA}

No que respecta á oferta de música en galego para menores de 16 anos, os datos indican que un $54,4 \%$ das persoas entrevistadas considera que a oferta é escasa, fronte a un $36,1 \%$ que pensa que é suficiente.

Oferta de música en galego para menores de 16 anos

\begin{tabular}{lcc} 
Música & Total & Porcentaxe \\
\hline Suficiente & 325 & 36,1 \\
Insuficiente & 490 & 54,4 \\
Ns/Nc & 85 & 9,4 \\
\hline
\end{tabular}

Fonte: Elaboración propia

A continuación relacionáronse os datos de oferta de música en galego para menores de 16 anos coas variables independentes que resultaron significativas, que son: idade, lingua habitual de expresión e ocupación.

No que se refire á variable de idade, obsérvase na gráfica que a medida que aumentan os grupos etarios, diminúe a porcentaxe de persoas que manifestan que a oferta de música en galego para menores de 16 anos é insuficiente. Así, o $66,67 \%$ das persoas máis novas, de entre 15 e 29 anos, consideran que esta oferta é escasa, o triplo das que consideran esta oferta suficiente. As diferenzas vanse reducindo a medida que se incrementa a idade ata chegar ao treitos das persoas maiores de 65 anos, onde a diferenza entre as que consideran que esta oferta é suficiente ou escasa é de 5,7 puntos porcentuais.

Oferta de música en galego para menores de 16 anos por idade

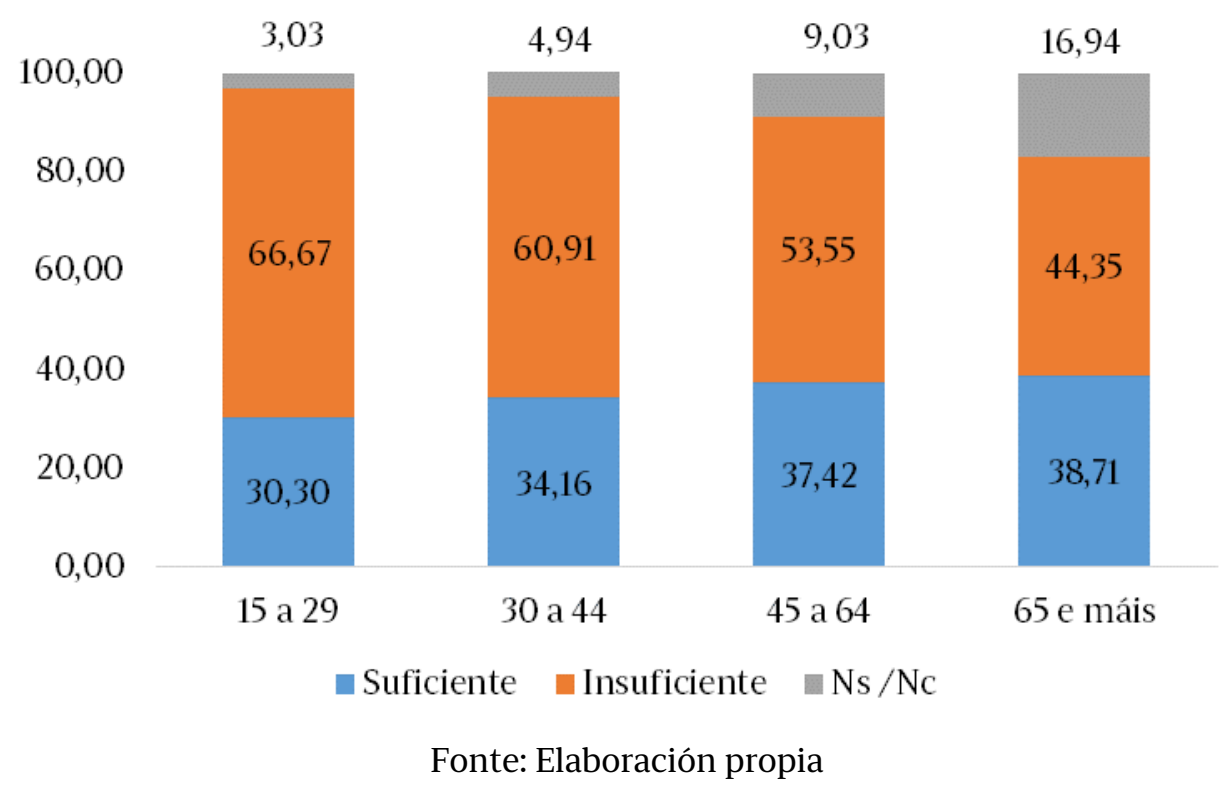

Con respecto á variable de ocupación, os datos mostran que son unha vez máis os estudantes e asalariados os que maioritariamente manifestan que a oferta de música en galego é escasa, con porcentaxes de resposta que superan o $60 \%$. Pero neste caso non se produce unha diferenza tan salientable entre as distintas categorías de ocupación, agás nos casos das categorías "labores do fo- 
gar” e "xubilado/pensionista”, que son taxas máis baixas e, ao mesmo tempo, son as que dan maior porcentaxe de falta de resposta.

Oferta de música en galego para menores de 16 anos por ocupación

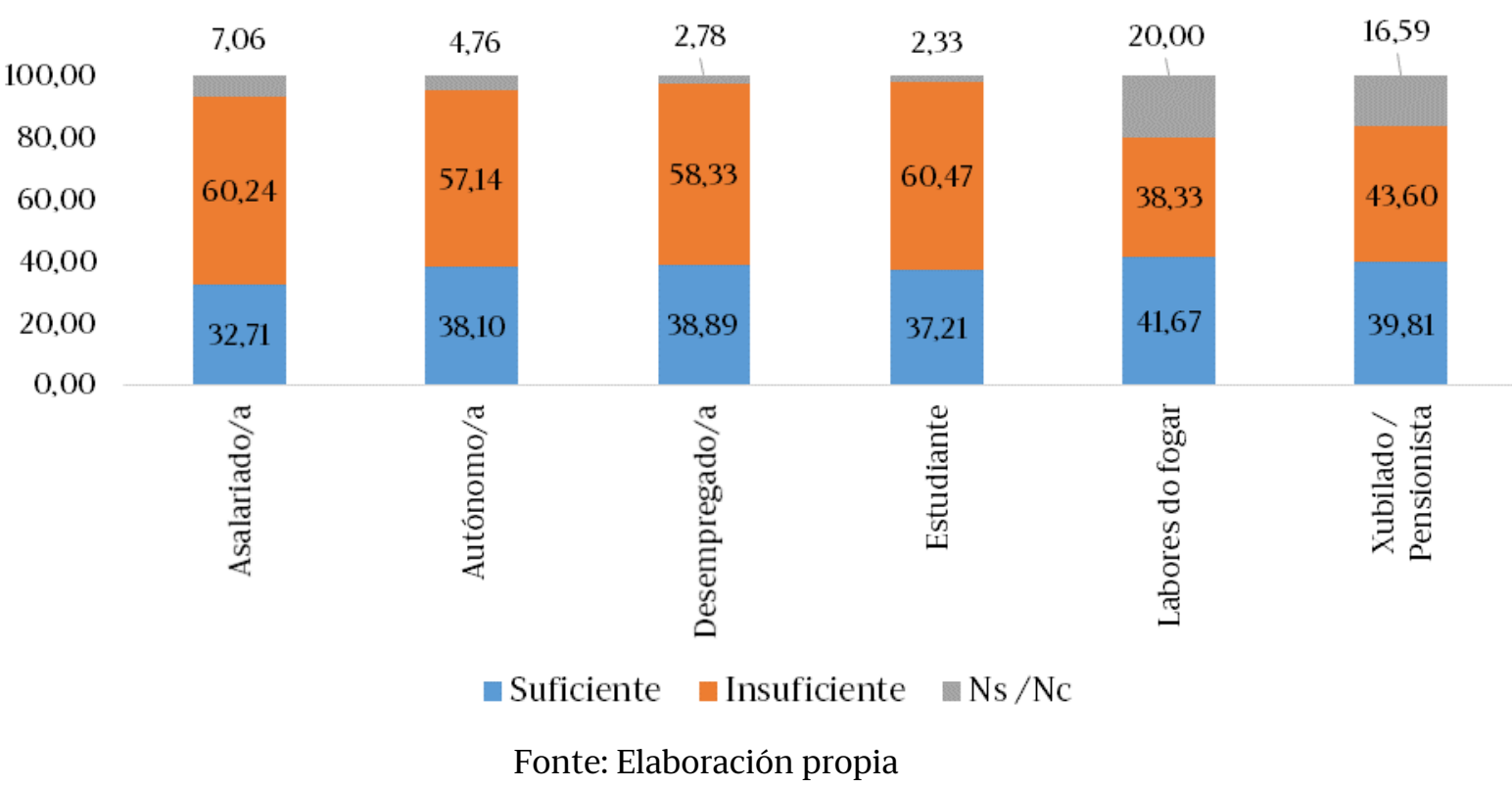

Por último, outra variable que resulta significativa en relación coa oferta de música en galego para menores de 16 anos é a de lingua habitual de expresión. Obsérvase que os/as falantes de galego, tanto monolingües como bilingües, son as persoas que demandan en maior medida máis música en galego para menores de 16 anos, concretamente un 61,22\% as monolingües e un 59,42\% as persoas que falan máis galego que castelán. A diferenza entre estas dúas categorías non é moi apreciable (1,8 puntos porcentuais), pero si o é entre as persoas que falan só ou preferentemente en castelán (12,6 puntos porcentuais). Tamén cómpre destacar que a diferenza entre as persoas monolingües en galego e en castelán que consideran escasa a oferta de música en galego para menores de 16 é de case 20 puntos porcentuais. Por último, son estas dúas categorías as que rexistran unha porcentaxe máis elevada de persoas que non responden a esta pregunta ou descoñecen a resposta, concretamente un 12,79\% das persoas monolingües en castelán e un 11,73\% das que só falan en galego. 
Oferta de música en galego para menores de 16 anos por lingua habitual de expresión

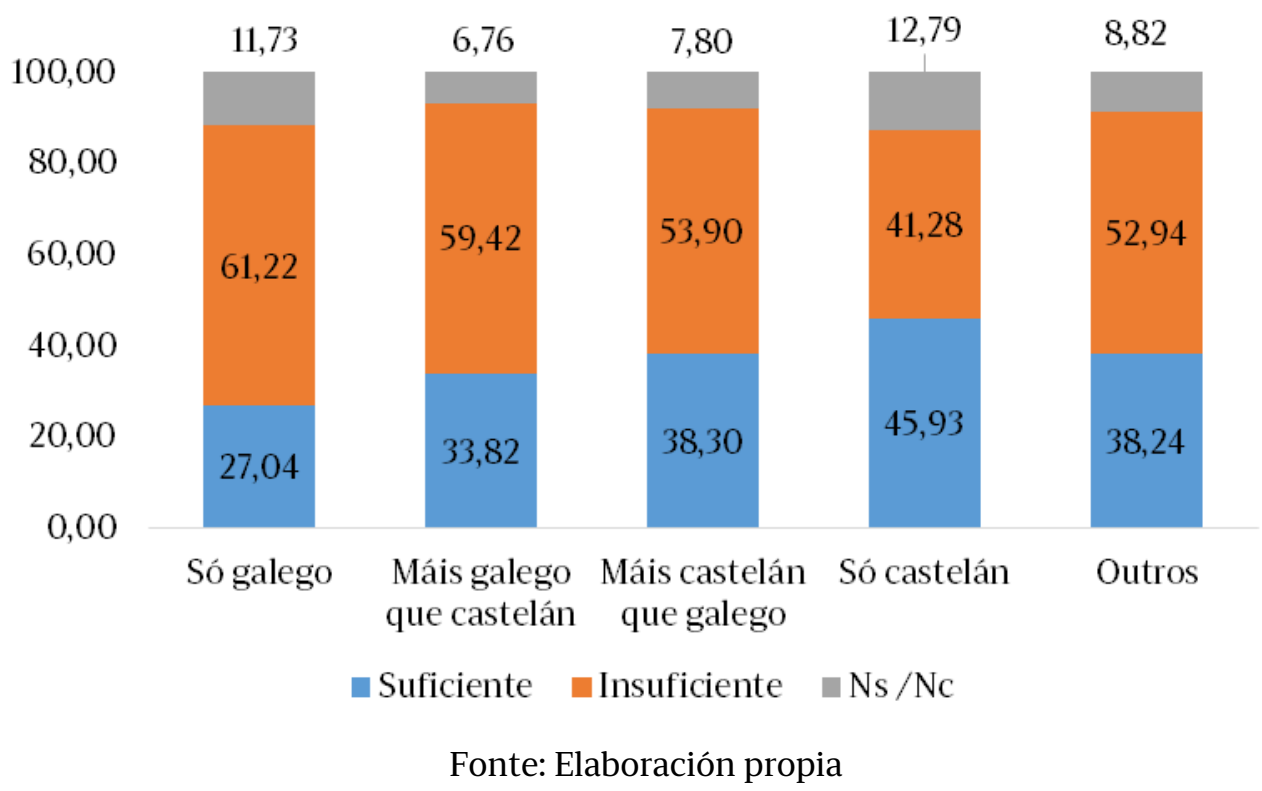

Ao igual ca nos produtos culturais que se analizaron nos apartados anteriores, preguntóuselles ás persoas enquisadas que tipo de música en galego para menores de 16 anos botan en falta. Así, as persoas que dixeron que a oferta deste produto cultural era insuficiente mencionaron as seguintes categorías: música de todo tipo, música infantil, música actual, música clásica, música tradicional e música doutro tipo.

Cómpre salientar que un 35,52\% declarou que botaba en falta todo tipo de música en galego para este treito de idade, máis dun 20\% pide máis música infantil e actual e, xa por debaixo desta taxa, atópase a música tradicional (un 13,76\%). Por último, cómpre sinalar que a música clásica apenas ten demanda para este treito de idade (un $0,82 \%$ ).

Tipoloxía de música en galego para menores de 16 anos que botan en falta as persoas que consideran escasa esta oferta (Resposta múltiple)
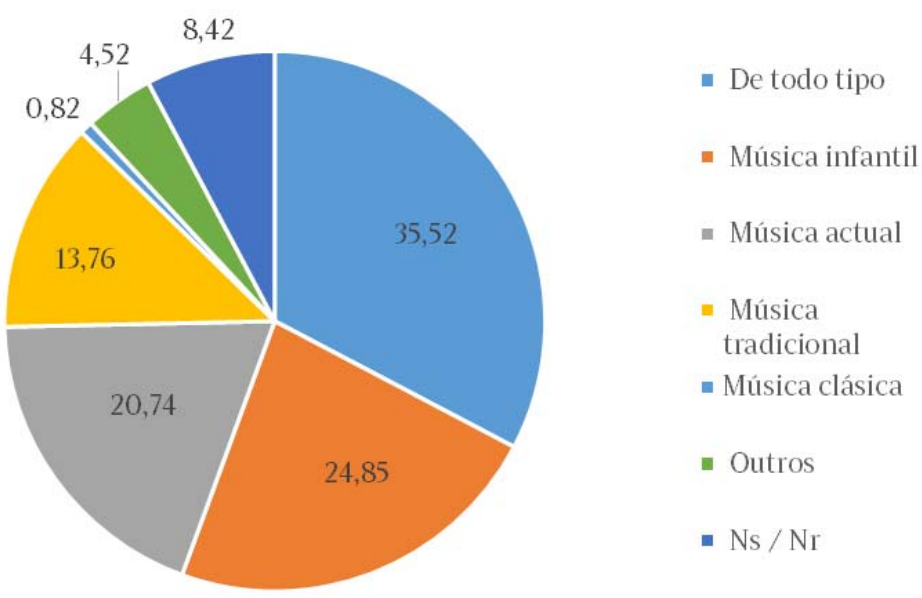

Fonte: Elaboración propia 


\subsection{MUSEOS E EXPOSICIÓNS}

Outro tipo de produto cultural que se analizou para coñecer a opinión das persoas enquisadas sobre a oferta cultural en galego para menores de 16 anos é a de museos e exposicións. Os datos indican que algo máis da metade das persoas entrevistadas consideran que é escasa, tal como se reflicte na seguinte táboa.

\section{Oferta de museos ou exposicións en galego para menores de 16 anos}

\begin{tabular}{lcc} 
Museos & Total & Porcentaxe \\
\hline Suficiente & 267 & 29,7 \\
Insuficiente & 487 & 54,1 \\
Ns/Nc & 146 & 16,2 \\
\hline
\end{tabular}

Fonte: Elaboración propia

Comprobouse que existe dependencia deste indicador coas seguintes variables: lingua habitual de expresión, nivel de ingresos do fogar, nivel de estudos e grao de equipamento cultural no fogar.

Ao comparar todos os grupos de lingua habitual de expresión, comprobouse que as persoas falantes de galego, tanto as que só falan esta lingua como as que tamén falan de cando en vez en castelán, son as que presentan unha porcentaxe máis alta de persoas que informan que a oferta de museos e exposicións en galego para menores é insuficiente.

\section{Oferta de museos ou exposicións en galego para menores de 16 anos por lingua habitual de expresión}

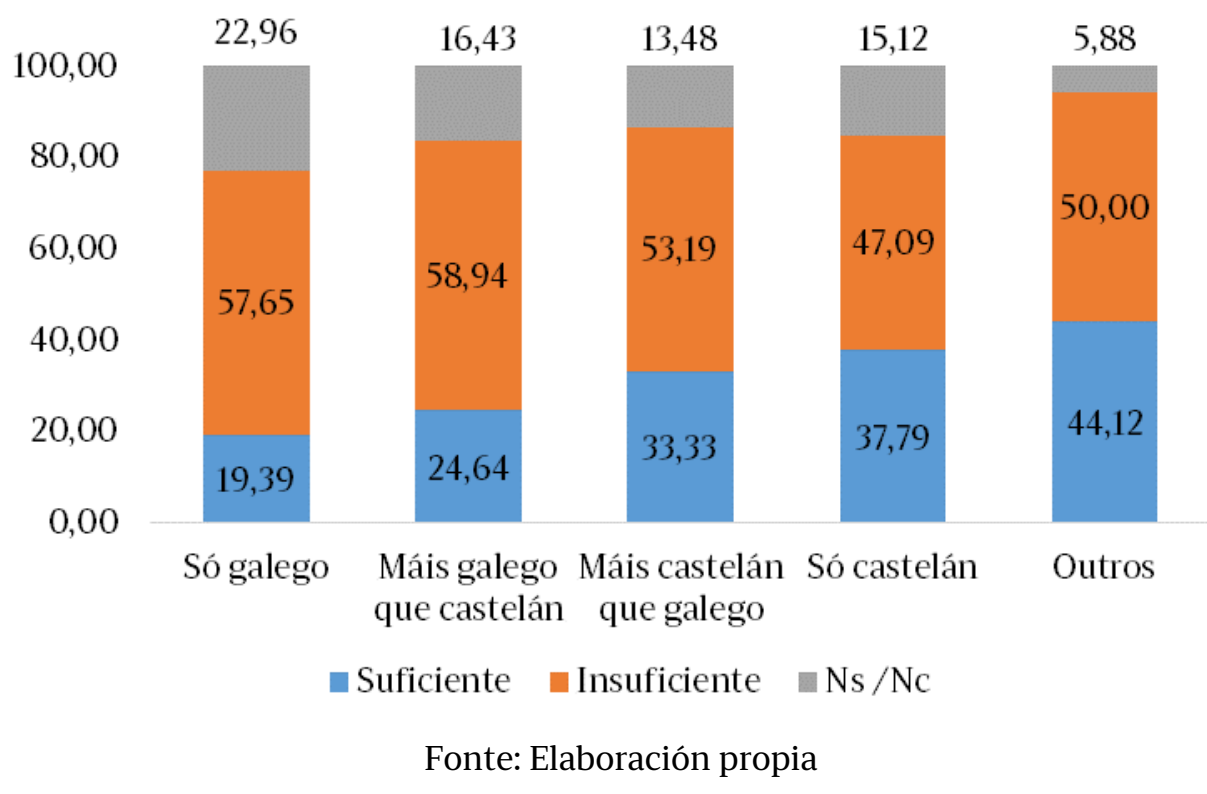

O cruzamento de datos relacionados coa oferta de museos e exposicións en galego para menores de 16 anos coa variable de nivel de ingresos dá como resultado que as persoas cuxos fogares teñen un nivel de ingresos de entre $1.000 \mathrm{e}$ 2.000 euros son as que consideran en maior proporción que esta oferta é escasa. As persoas que viven nun fogar cuns ingresos de entre 2.000 e 3.000 euros son as que están máis satisfeitas con esta oferta cultural para menores de 16 anos, xa que un $35,94 \%$ delas considera que é suficiente. 


\section{Oferta de museos ou exposicións en galego para menores de 16 anos} por nivel de ingresos no fogar

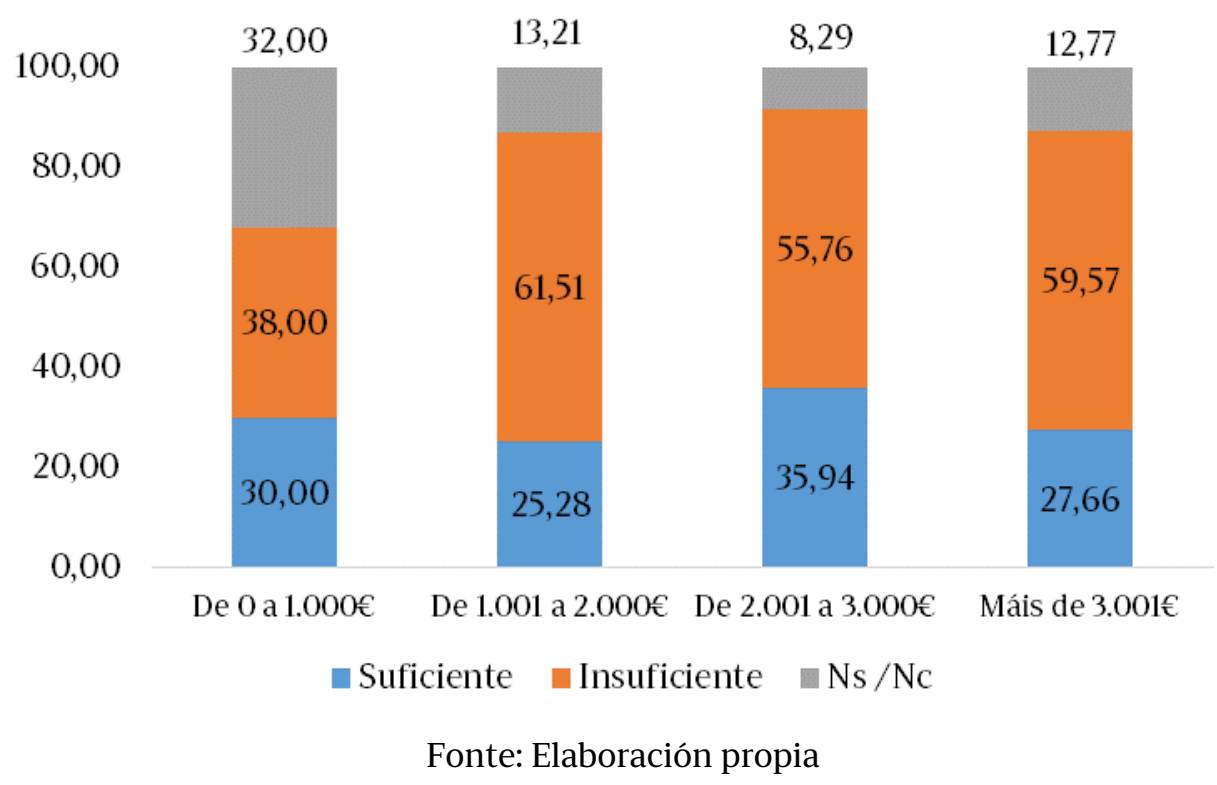

En relación co grao de equipamento de contido cultural, as persoas que dispoñen dun nivel medio de equipamento cultural no seu fogar son as que rexistran a porcentaxe máis alta de persoas que afirman que a oferta de museos con contidos en galego é escasa $58,04 \%$ ).

\section{Oferta de museos ou exposicións en galego para menores de 16 anos por nivel de equipamento no fogar}

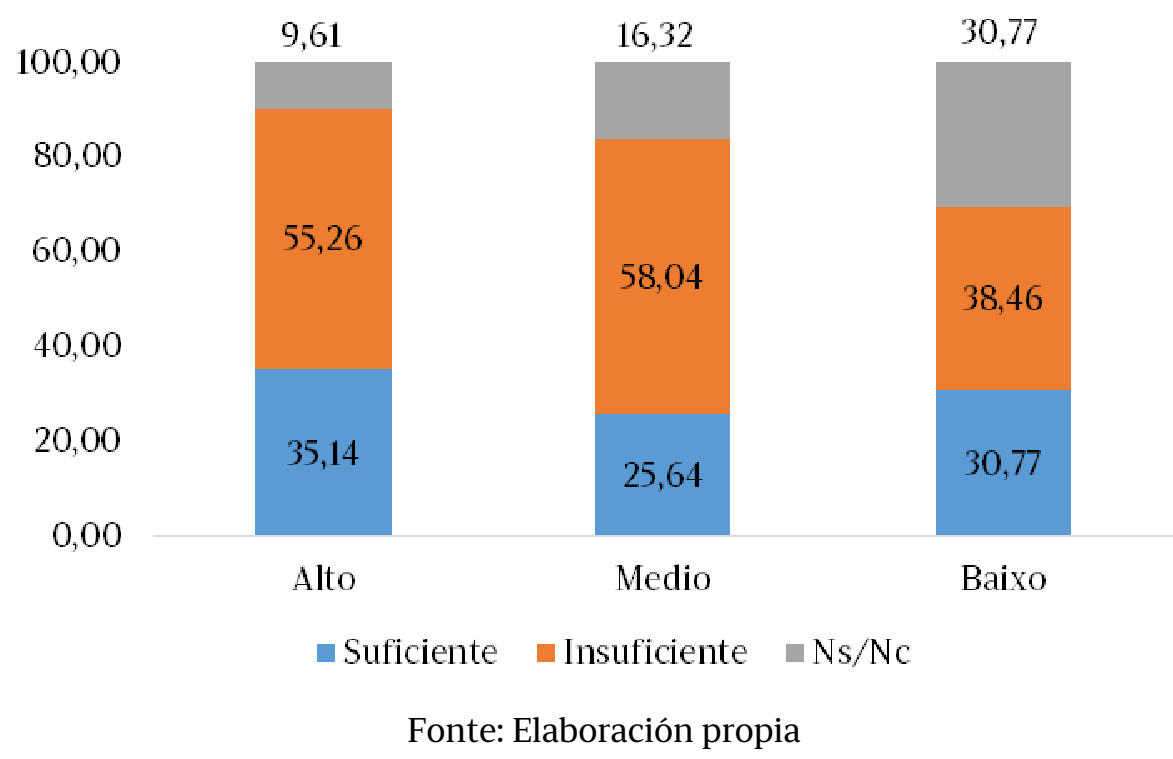

Con respecto ao tipo de oferta de museos con contidos en galego para menores de 16 anos que se consideran máis escasos, establecéronse as seguintes categorías: de todo tipo, históricos/xacementos, científicos divulgativos, ciencias naturais, artes visuais, infantil/xuvenil, interactivos, culturais e relacionados con Galicia. Máis da metade das persoas enquisadas botan en falta unha oferta cultural de museos e exposicións de todo tipo con contidos en galego. Os máis men- 
cionados, cunha porcentaxe moi semellante de mención, arredor do 11\%, son os museos históricos/xacementos (11,36\%), os científicos divulgativos $(10,95 \%)$ e os museos de ciencias naturais (10.54\%).

Tipoloxía de museos ou exposicións en galego para menores de 16 anos que botan en falta as persoas que consideran escasa esta oferta (Resposta múltiple)

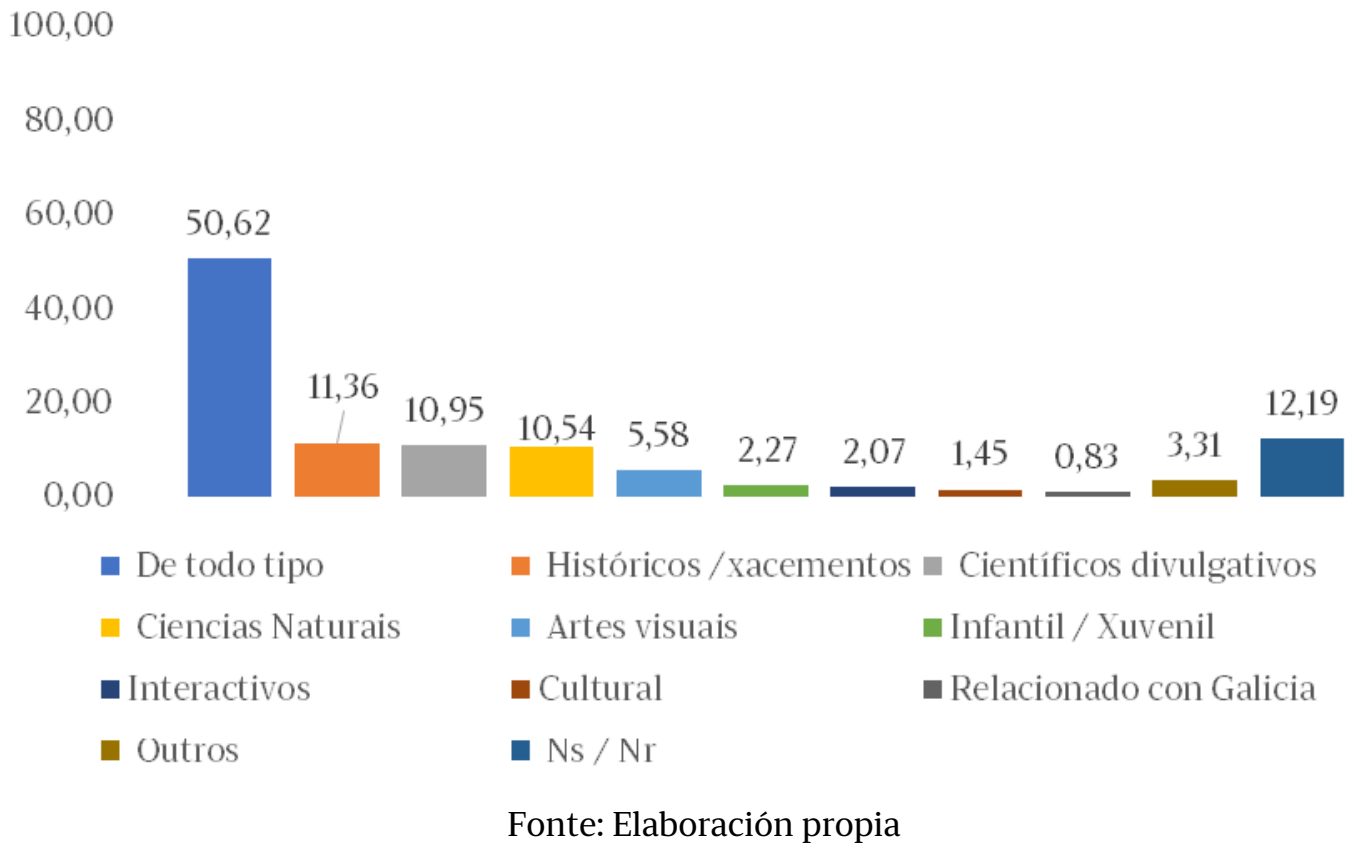

\subsection{TELEVISIÓN}

O seguinte produto que se analiza para coñecer a oferta cultural para menores de 16 anos é a televisión. A oferta deste medio de comunicación é a que rexistra unhas porcentaxes máis igualadas entre as persoas que a consideran suficiente ou escasa, cunha diferenza de menos de 8 puntos porcentuais. En todo caso, ningunha das dúas respostas chega ao 50\%, tal como se pode comprobar na seguinte táboa.

\section{Oferta de televisión en galego para menores de 16 anos}

Total Porcentaxe

\begin{tabular}{lcc}
\hline Suficiente & 370 & 41,1 \\
Insuficiente & 446 & 49,6 \\
Ns/Nc & 84 & 9,3 \\
\hline \multicolumn{3}{c}{ Fonte: Elaboración propia }
\end{tabular}

Cando se cruzan estes datos coas variables independentes, pódese constatar que as que resultaron significativas á hora de valorar a oferta de televisión en galego para menores de 16 anos son as seguintes: idade, tipoloxía do contorno de residencia, ocupación, lingua habitual de expresión, lingua en que aprenderon a falar os fillos/as, grao de equipamento cultural e a subscrición ou non a calquera plataforma dixital de contido cultural. 
A oferta de televisión en galego percíbese como insuficiente canto máis novas son as persoas entrevistadas e esta percepción vai diminuíndo progresivamente segundo aumenta a idade. Así, mentres que o $66,67 \%$ das persoas que pertencen ao treito de idade que vai de 15 a 29 anos considera que a televisión en galego para menores de 16 anos é escasa, esa porcentaxe redúcese en dez puntos no treito de idade de 30 a 44 anos e en 26,8 puntos para os maiores de 65 anos. As persoas que pertencen ao treito de idade de 45 a 64 anos teñen unha opinión bastante igualada a este respecto, xa o $46,45 \%$ considera que a oferta é insuficiente e o 45,81\% pensa que a programación de televisión en galego que hai para menores de 16 anos é suficiente.

Oferta de televisión en galego para menores de 16 anos por idade

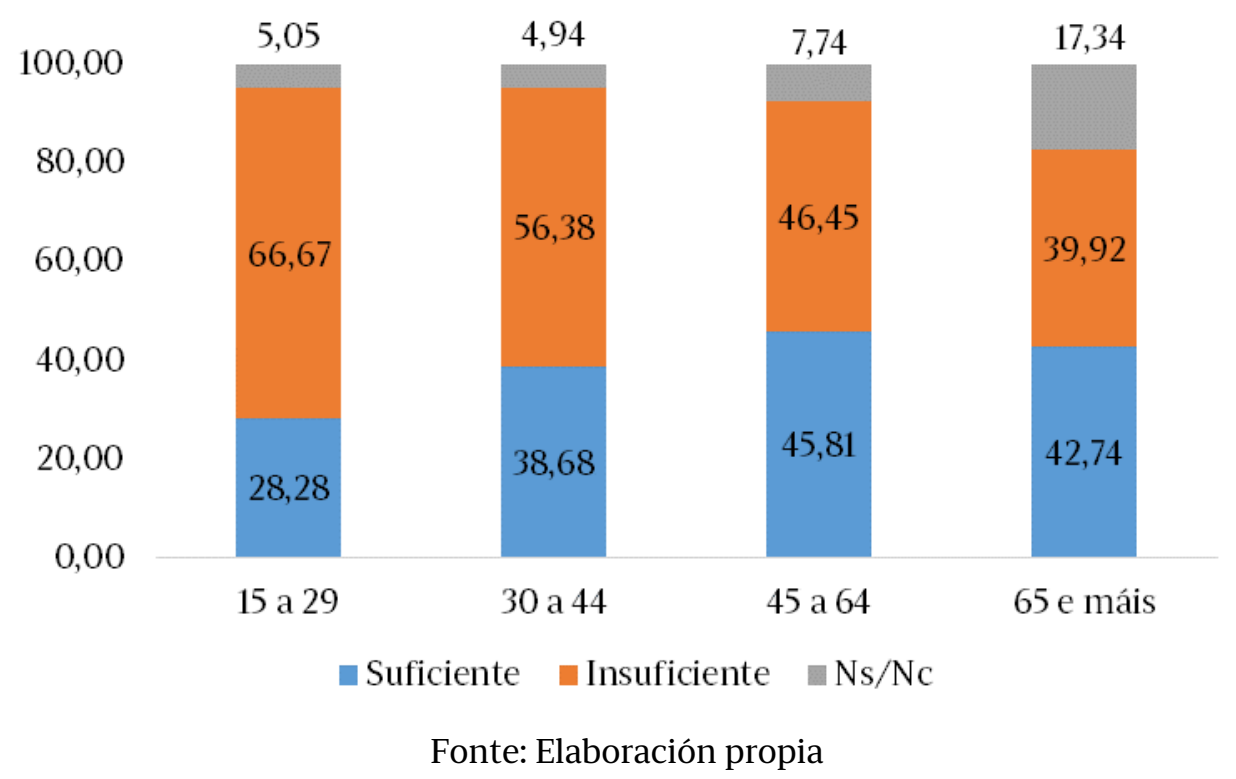

Con respecto ao hábitat de residencia, os datos reflicten que se produce unha dicotomía entre as persoas que viven nas cidades e as que viven en vilas pequenas e nas aldeas, xa que as porcentaxes que se rexistran son moi semellantes: un $53,77 \%$ das persoas que viven nas cidades, un $51,46 \%$ das que viven en vilas pequenas e un 52,72\% das que viven en núcleos pequenos ou aldeas consideran que a oferta de televisión en galego é escasa. Porén, no hábitat periurbano, a porcentaxe de persoas que consideran suficiente esta oferta cultural supera en case nove puntos porcentuais á das que a ven escasa. 


\section{Oferta de televisión en galego para menores de 16 anos por tipoloxía do contorno de residencia}

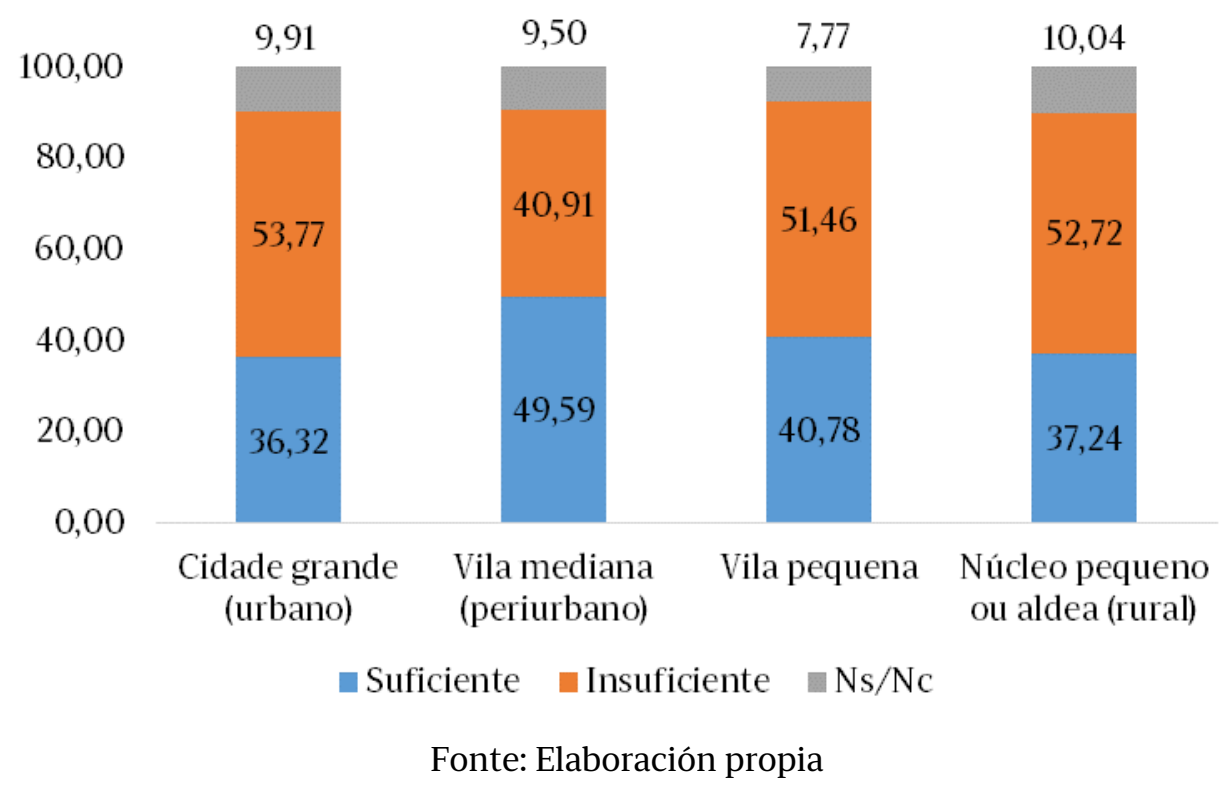

A respecto da ocupación, son as persoas que están no paro as que consideran en maior proporción que a oferta de televisión en galego para menores de 16 anos é escasa, concretamente un $58,33 \%$ das persoas entrevistadas que se atopan neste grupo.

Oferta de televisión en galego para menores de 16 anos por ocupación

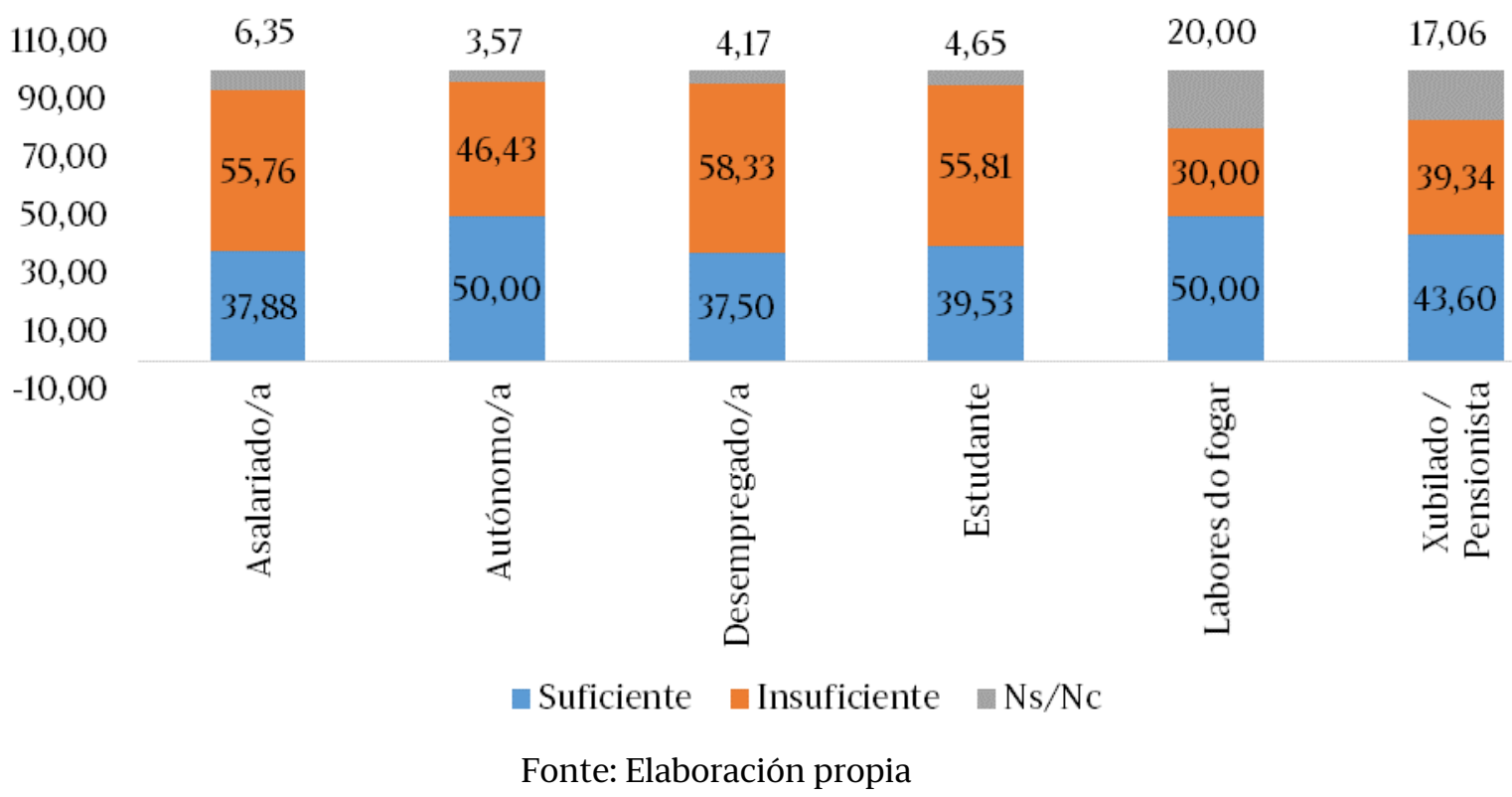

Coma en casos anteriores, confírmase que as persoas que viven nun fogar en que se fala máis galego que castelán ou só galego son as que consideran en maior proporción que a oferta de televisión en galego para menores de 16 anos é escasa, concretamente un $52,7 \%$. 
Oferta de televisión en galego para menores de 16 anos por lingua habitual de expresión

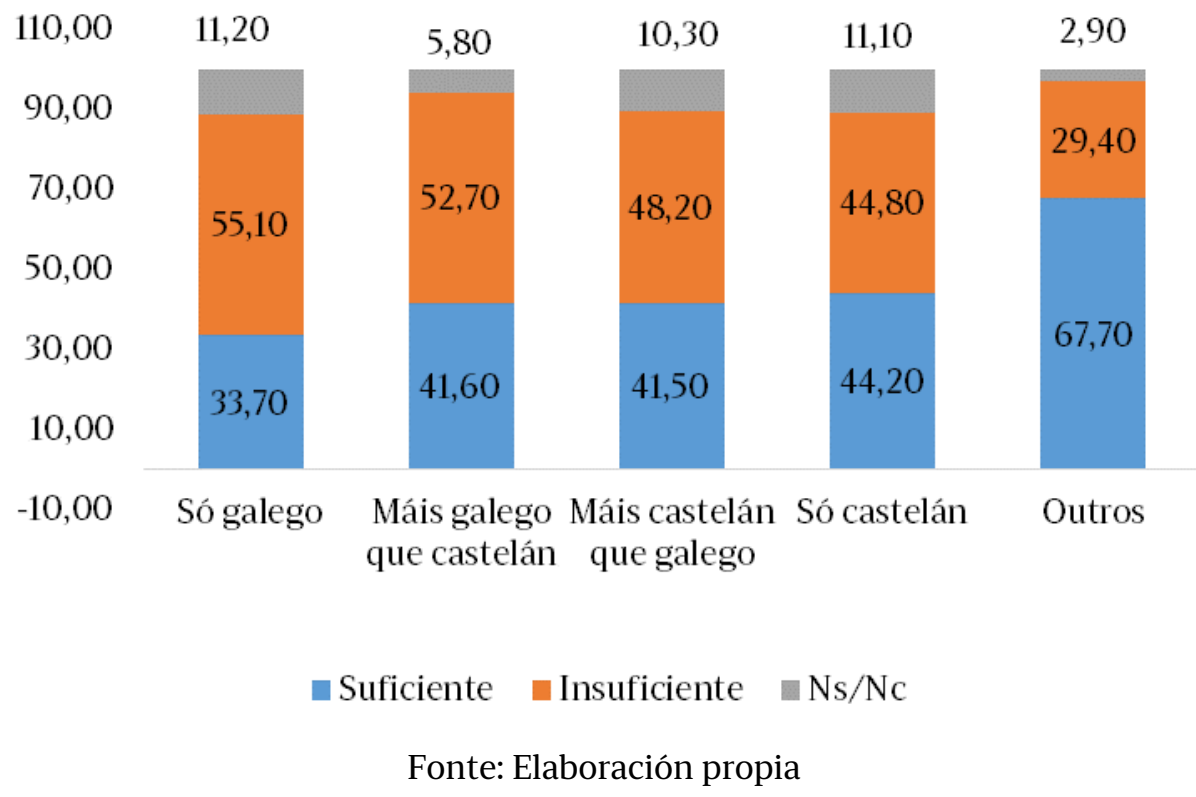

Neste mesmo sentido, máis da metade das persoas galegofalantes (un $50,36 \%$ ) manifestan a insuficiencia da oferta, mentres que as que utilizan o castelán teñen unha opinión máis favorable sobre a oferta de televisión en galego para menores (un 45,67\%), como amosa a seguinte gráfica.

\section{Oferta de televisión en galego para menores de 16 anos por lingua na que aprenderon a falar os fillos/as}

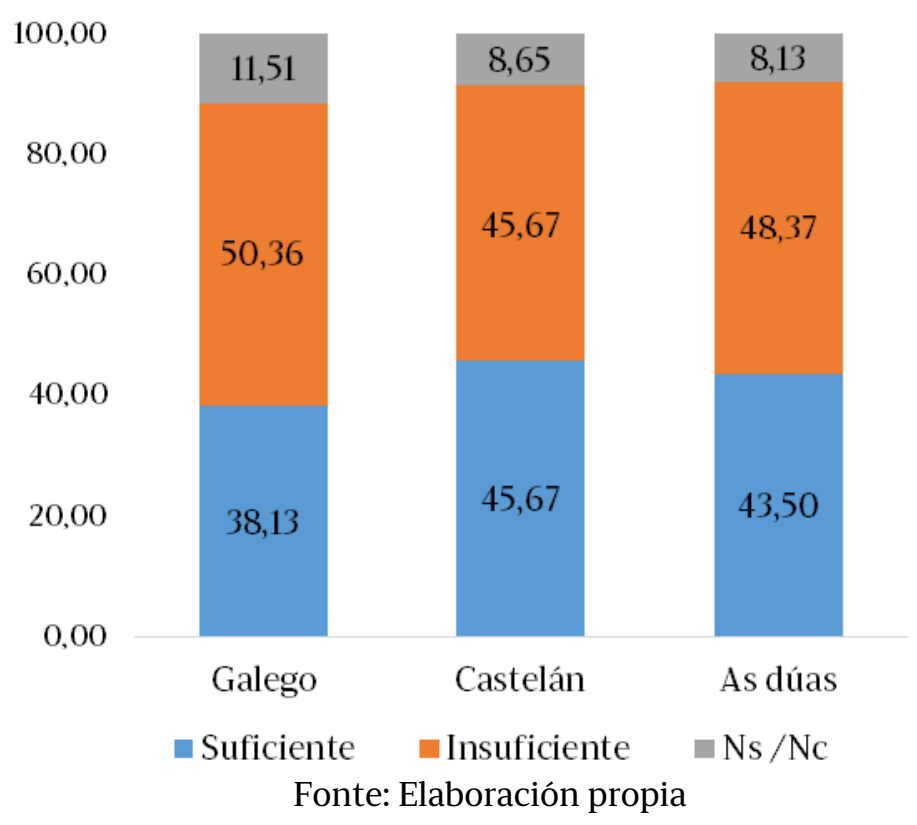

Por último, se se teñen en conta as variables do grao de equipamento cultural no fogar e de subscrición ou non a plataformas dixitais de contidos culturais, atópase unha vez máis un paralelismo entre aquelas persoas que teñen un grao alto de equipamento no fogar e as que están subscritas a plataformas dixitais de contidos culturais, xa que en ambos os casos máis da metade das persoas que 
pertencen a estes grupos consideran que a oferta de televisión en galego para menores de 16 anos é escasa: un 55,86\% no caso fogares cun alto gra de equipamento e un 53,42\% no caso das persoas que están subscritas a plataformas dixitais.

\section{Oferta de televisión en galego para menores de 16 anos por grao de equipamento cultural no fogar}

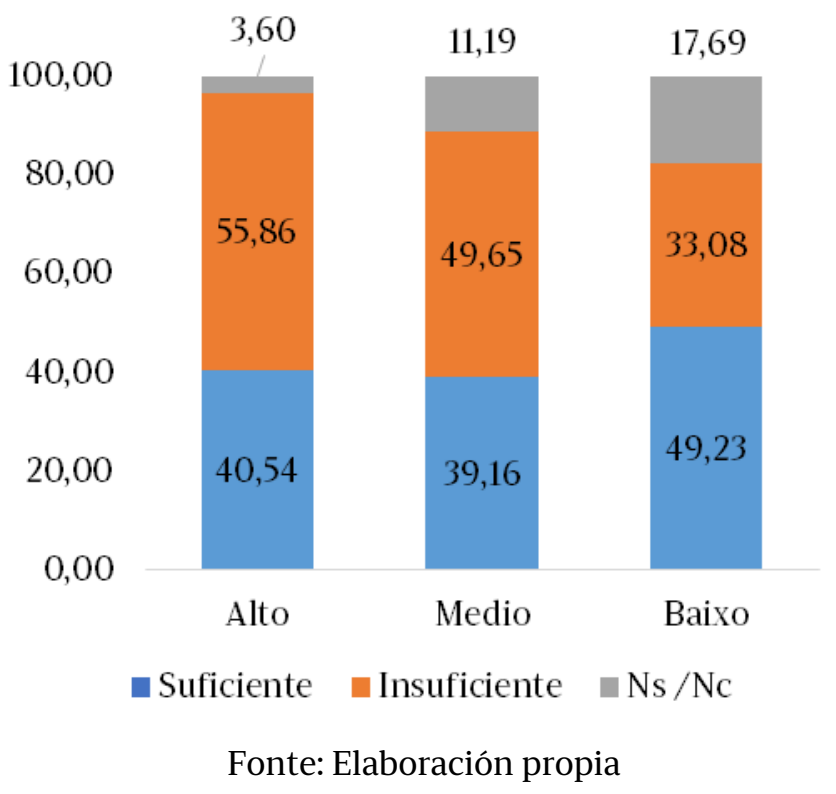

\section{Oferta de televisión en galego para menores de 16 anos por subscrición ou non a plataformas dixitais de contidos culturais}

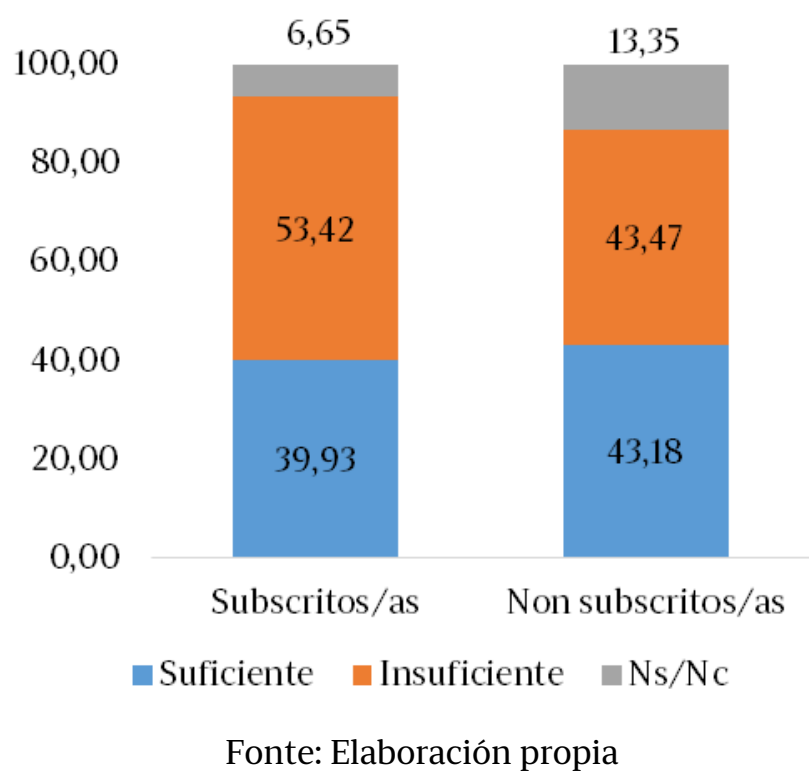

Cando se pregunta que tipo de programación botan en falta as persoas que manifestan que a oferta de televisión é insuficiente, as principais respostas son: animación (30,34\%), programas educativos (22,92\%) e series (10,56\%). 


\section{Tipoloxía de TV que botan en falta as persoas que consideran insuficiente esta oferta cultural}

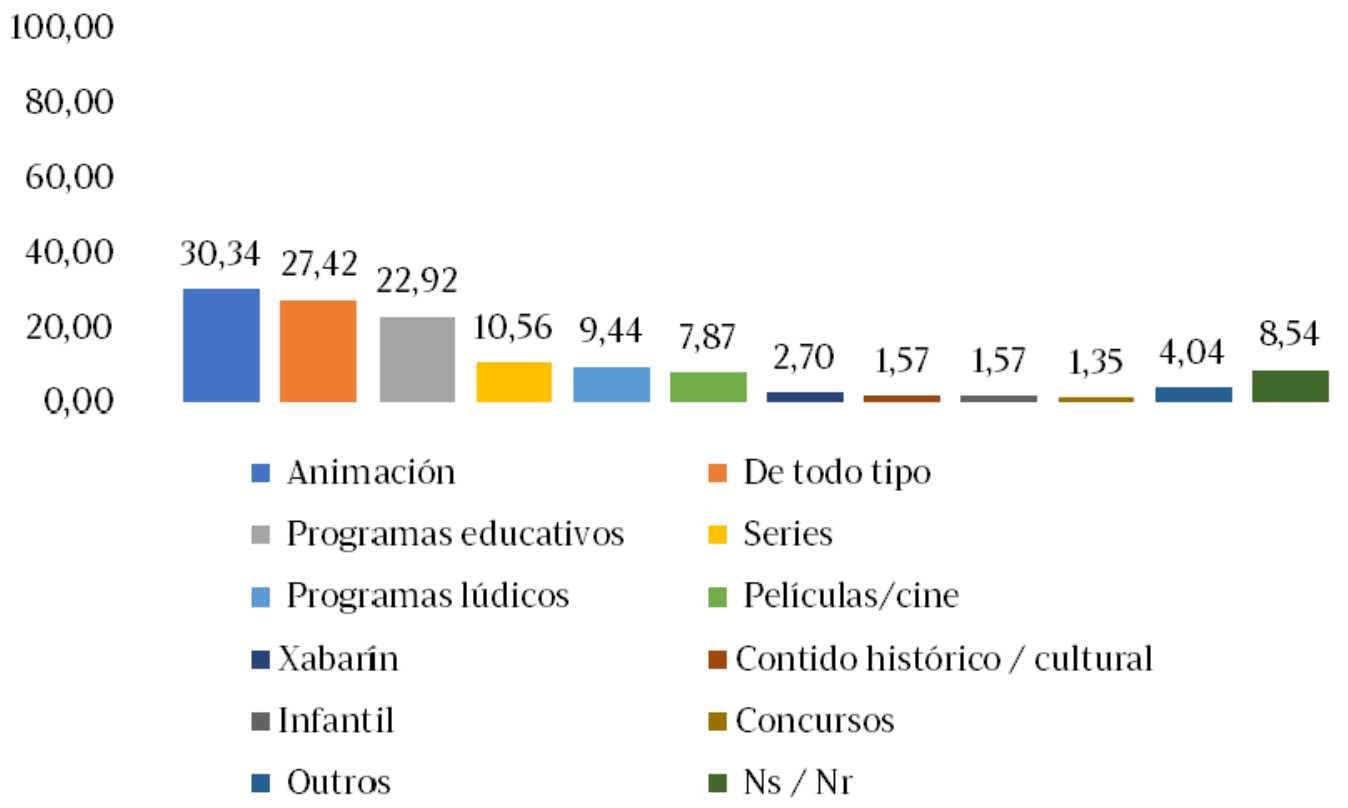

Fonte: Elaboración propia

\subsection{CONTIDOS AUDIOVISUAIS}

Ao estudar a oferta de contidos audiovisuais (cine/películas, series, vídeos...) en galego para menores de 16 anos, o 66,1\% das persoas entrevistadas manifesta que é insuficiente e un 23,3\% considéraa suficiente, tal como se reflicte na seguinte táboa.

Oferta de contidos audiovisuais en galego para menores de 16 anos

\begin{tabular}{lcc} 
& Total & Porcentaxe \\
\hline Suficiente & 210 & 23,3 \\
Insuficiente & 595 & 66,1 \\
Ns/Nc & 95 & 10,6 \\
\hline
\end{tabular}

Fonte: Elaboración propia

A continuación móstranse os resultados dos cruzamentos destes datos coas variables independentes que proporcionaron diferenzas significativas e que son as seguintes: se hai menores ou non no fogar, idades, nivel de estudos, ocupación, tipoloxía do contorno de residencia, grao de equipamento cultural non fogar e, por último, se os membros do fogar están subscritos ou non nalgunha plataforma dixital de contido cultural.

En primeiro lugar, constátase que nos fogares onde viven menores de 16 anos se considera que a oferta de contidos audiovisuais en galego dirixidos especificamente para este treito de poboación é escasa nunha proporción moi significativa $(75,06 \%$ das persoas entrevistadas). 


\section{Oferta de contidos audiovisuais en galego para menores de 16 anos} segundo haxa ou non menores no fogar

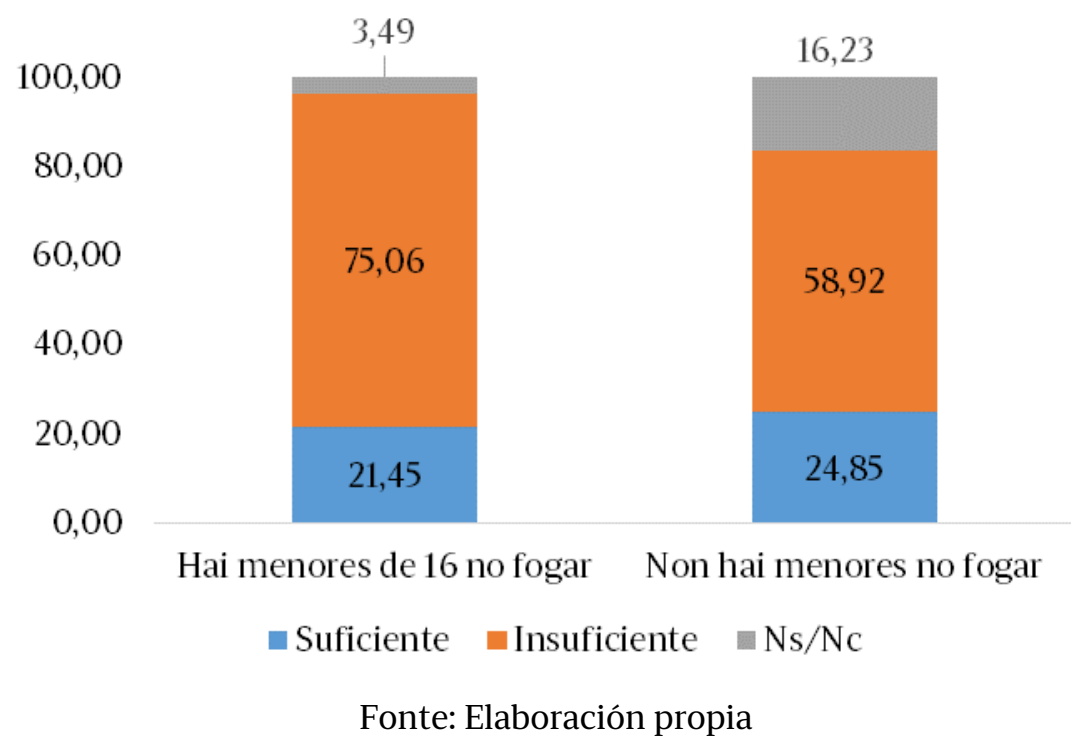

Se se ten en conta a variable de idade, pódese comprobar que canto máis novas son as persoas entrevistadas, maior é a porcentaxe das que consideran insuficientes os contidos audiovisuais en galego. Así, un 79,8\% das persoas entre 15 a 29 anos considera que a oferta destes contidos audiovisuais é escasa. Esta porcentaxe vaise reducindo a medida que vai aumentando a idade ata as persoas maiores de 65 anos, treito etario no que se reduce esta consideración en case 30 puntos porcentuais con respecto ás persoas máis novas. Neste treito de idade é, unha vez máis, ao igual que acontecía no caso doutros contidos culturais, onde se rexistra unha maior proporción de persoas que non contestan ou non saben responder a esta pregunta, concretamente un $22,18 \%$.

oferta de contidos audiovisuais en galego para menores de 16 anos por idade

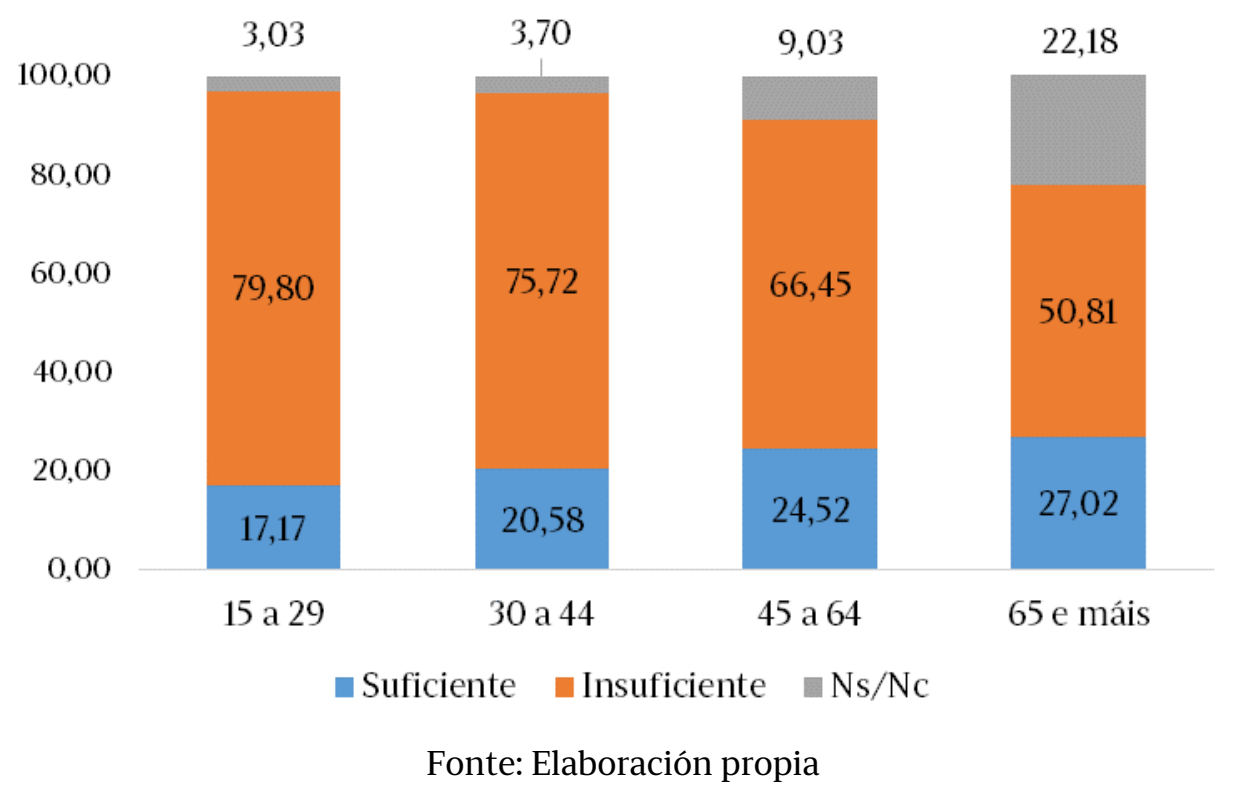


Con respecto ao nivel de estudos, pódese comprobar no seguinte gráfico que canto máis elevado é o nivel de estudos maior é a porcentaxe de persoas que consideran que a oferta de contidos audiovisuais en galego para menores de 16 anos é insuficiente, porcentaxe que supera o 70\%. Por outra banda, cómpre salientar que a porcentaxe de persoas sen estudos que non contestaron ou non souberon contestar a esta pregunta é moi elevada $(53,9 \%)$.

Oferta de contidos audiovisuais en galego para menores de 16 anos por nivel de estudos

\begin{tabular}{|c|c|c|c|c|c|c|}
\hline مסת 10 & 53,85 & 22,36 & 6,90 & 6,78 & 10,66 & 6,00 \\
\hline 80,00 & \multirow{5}{*}{$\begin{array}{r}30,77 \\
15,38\end{array}$} & \multirow{5}{*}{$\begin{array}{l}43,48 \\
34,16\end{array}$} & \multirow{5}{*}{$\begin{array}{l}64,94 \\
28,16\end{array}$} & \multirow{5}{*}{$\begin{array}{l}70,06 \\
23,16\end{array}$} & \multirow{5}{*}{$\begin{array}{l}74,59 \\
14,75\end{array}$} & \multirow{5}{*}{$\begin{array}{r}76,40 \\
17,60\end{array}$} \\
\hline 60,00 & & & & & & \\
\hline 40,00 & & & & & & \\
\hline 20,00 & & & & & & \\
\hline \multirow{2}{*}{0,00} & & & & & & \\
\hline & 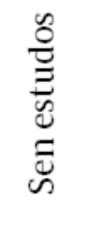 & 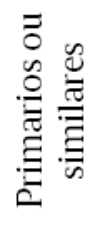 & 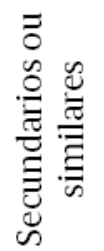 & 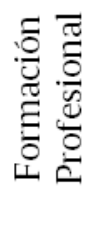 & 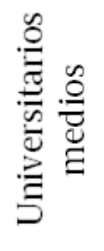 & 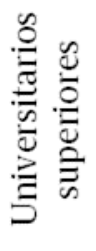 \\
\hline
\end{tabular}

Fonte: Elaboración propia

Verbo da variable de ocupación, son os asalariados e estudantes os que proporcionan unha porcentaxe máis elevada de persoas que consideran escasa a oferta de contidos dixitais en galego para menores de 16 anos: 76\% no primeiro caso e $74,42 \%$ no segundo.

Oferta de contidos audiovisuais en galego para menores de 16 anos por ocupación

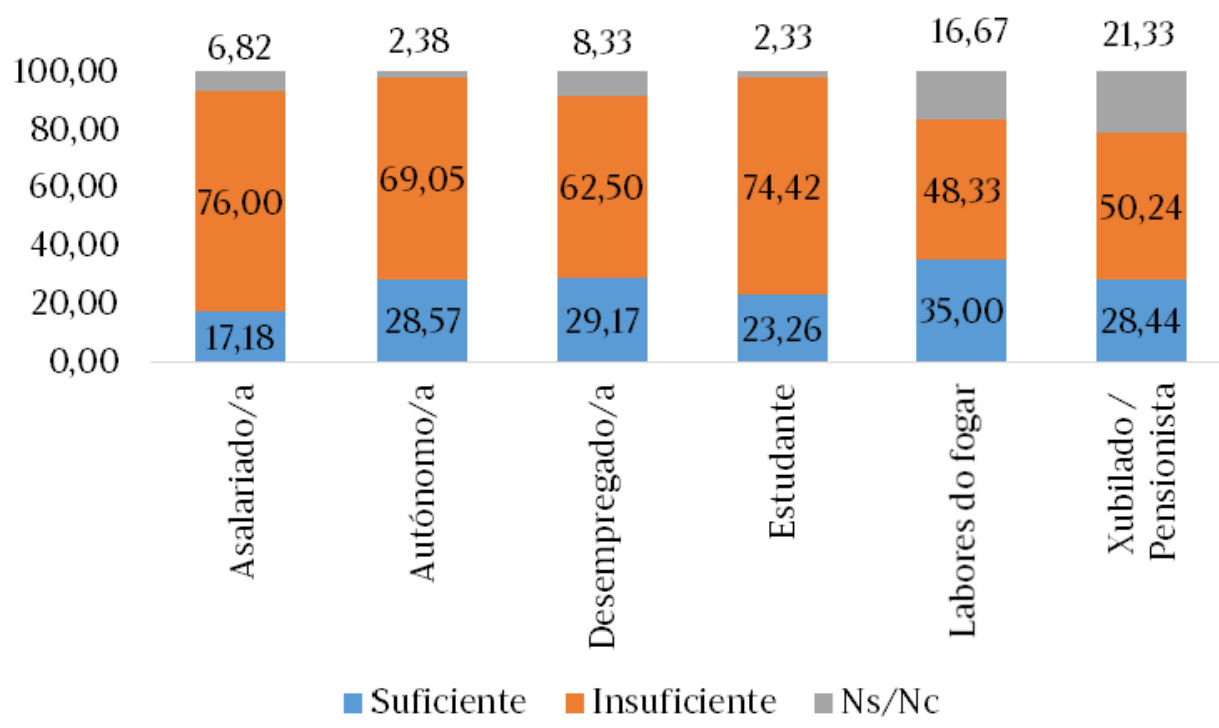

Fonte: Elaboración propia 
Segundo o contorno de residencia, a tendencia é que canto máis urbano é o hábitat onde viven as persoas entrevistadas máis alta é a porcentaxe de persoas que opinan que a oferta de contidos audiovisuais en galego para menores de 16 anos é insuficiente. Porén, este dato contrasta coa situación que semella reflectirse no contorno periurbano, xa que é onde se dá unha porcentaxe máis elevada de persoas que opinan que a oferta é suficiente, concretamente un 29,3\% das persoas entrevistadas. Isto significa que son case nove puntos porcentuais máis que no contorno rural e case doce máis que no contorno urbano.

Oferta de contidos audiovisuais en galego para menores de 16 anos por contorno de residencia

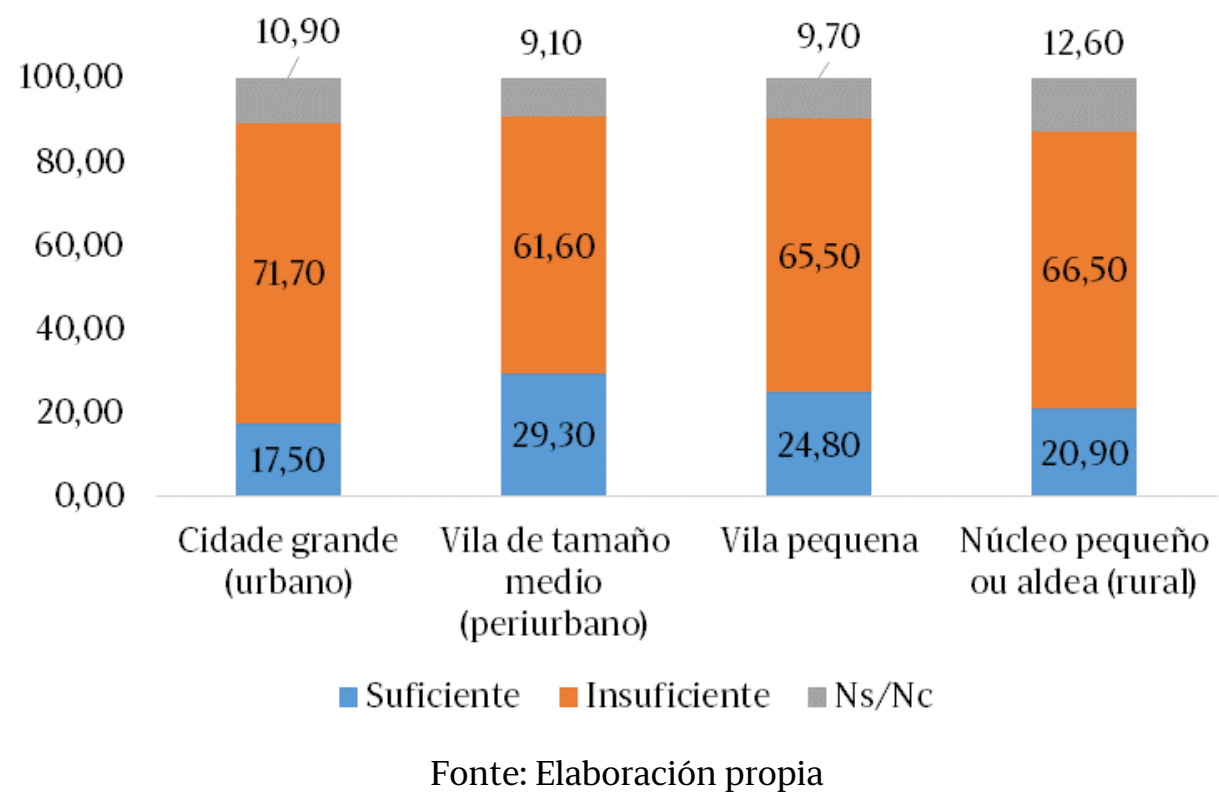

Por último, se se teñen en conta as variables de grao de equipamento tecnolóxico e cultural no fogar, pódese observar nas seguintes gráficas que as porcentaxes de persoas cun nivel de equipamento cultural alto no seu fogar e que están subscritas a plataformas dixitais de contidos culturais coinciden á hora de considerar escasa a oferta de contidos audiovisuais en galego para menores de 16 anos: un 72,07\%, no caso dos fogares cun grao alto de equipamento e un 72,09\% nos fogares cuxos membros están subscritos a plataformas dixitais. 
Oferta de contidos audiovisuais en galego para menores de 16 anos por grao de equipamento cultural no fogar

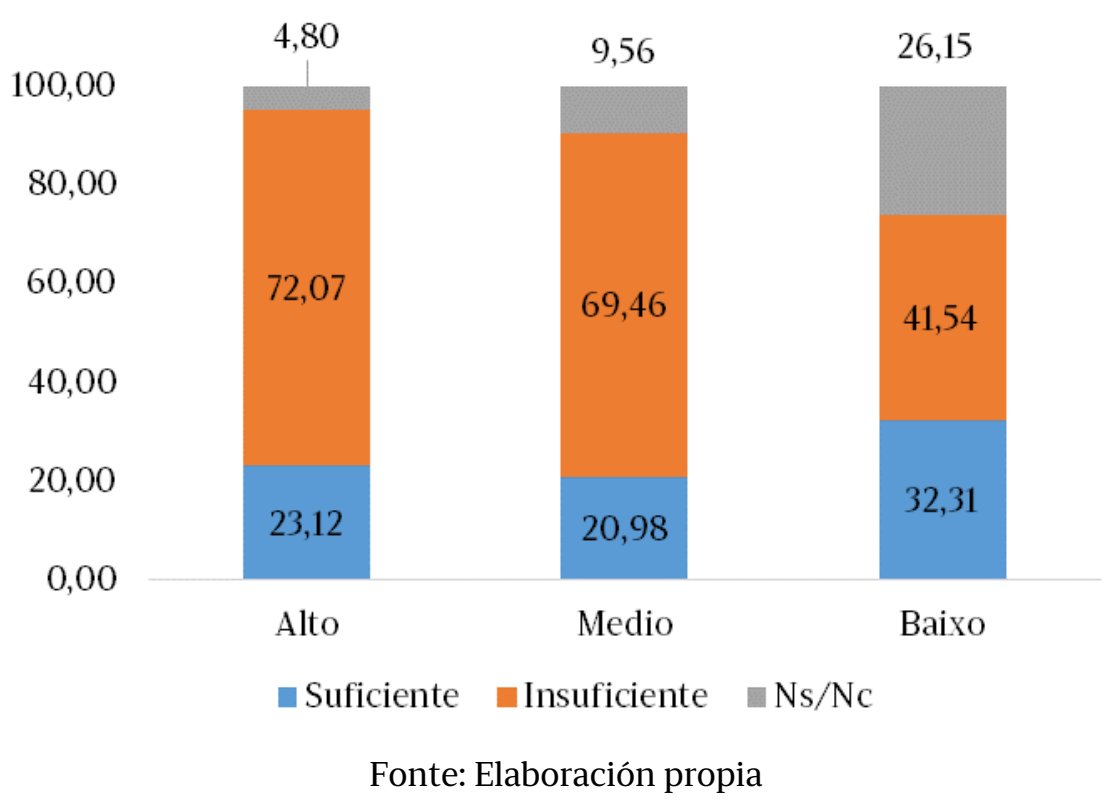

Oferta de contidos audiovisuais en galego para menores de 16 anos por subscrición ou non a plataformas dixitais de contidos culturais

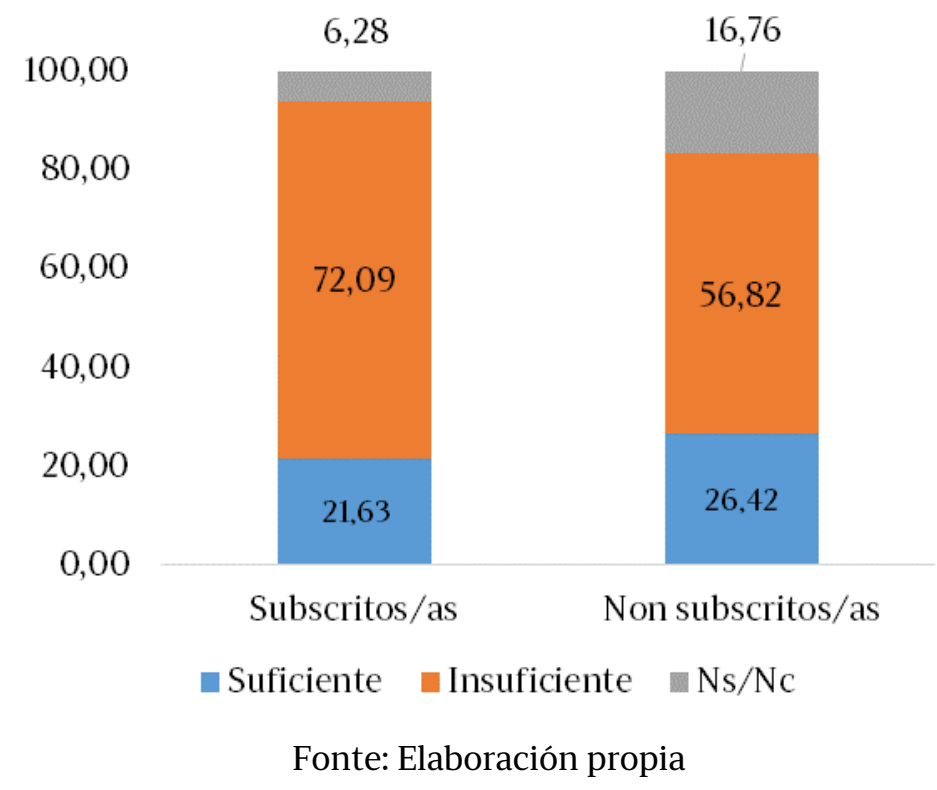

Ante a pregunta de que tipo de contidos audiovisuais en galego para menores de 16 anos botan en falta as persoas entrevistadas, as categorías mencionadas foron as seguintes: series, cine, canles de vídeo, televisión á carta, contidos educativos, debuxos animados/animación, contidos dirixidos a un público infantil, documentais, xogos e/ou videoxogos.

Como aconteceu noutro tipo de contidos audiovisuais, a maioría das persoas entrevistadas demandan contidos audiovisuais en galego de todo tipo $(41,92 \%)$. As categorías máis demandadas son as de series $(15,49 \%)$, cine $(14,14 \%)$ e debuxos animados e/ou animación (13,97\%). 


\section{Tipoloxía de contidos audiovisuais que botan en falta as persoas que consideran insuficiente a oferta}

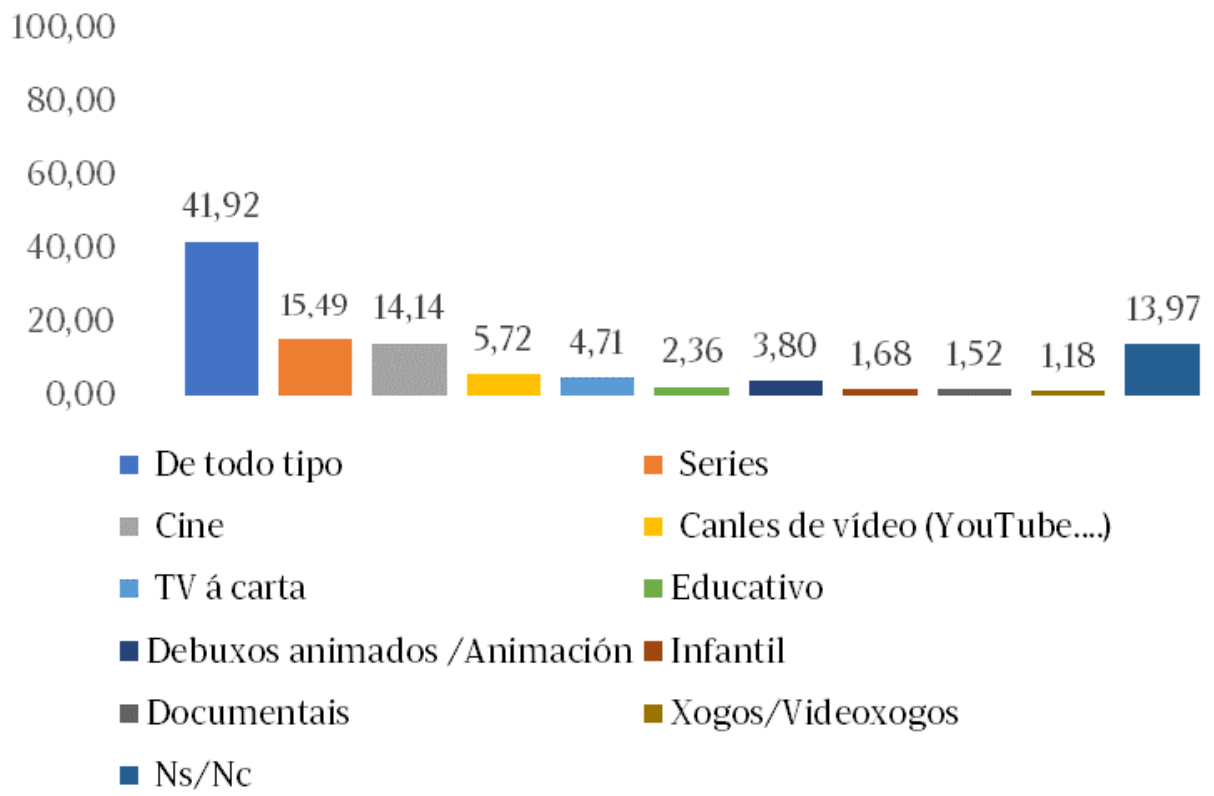

Fonte: Elaboración propia

\subsection{XOGO TRADICIONAL E VIDEOXOGOS}

A última categoría de contidos culturais que se analiza neste capítulo é a de xogos en galego para menores de 16 anos. Tendo en conta os datos que se mostran a continuación, un $66,2 \%$ das persoas entrevistadas considera esta oferta escasa, mentres que tan só o 17,9\% pensa que a que hai é suficiente.

\section{Oferta de xogos en galego para menores de 16 anos}

\begin{tabular}{lcc} 
& Total & Porcentaxe \\
\hline Suficiente & 161 & 17,9 \\
Insuficiente & 596 & 66,2 \\
Ns/Nc & 143 & 15,9 \\
\hline
\end{tabular}

Fonte: Elaboración propia

A primeira variable que inflúe á hora de analizar a oferta de xogos en galego para menores de 16 anos é a presenza de menores no fogar. Así, obsérvase que nos fogares onde viven menores un $78,05 \%$ das persoas entrevistadas admite que a oferta de xogos é escasa, en contraste cos fogares en que non viven menores, onde esta porcentaxe se reduce en máis de 20 puntos porcentuais. 
Oferta de xogos en galego para menores de 16 anos, segundo haxa ou non menores no fogar

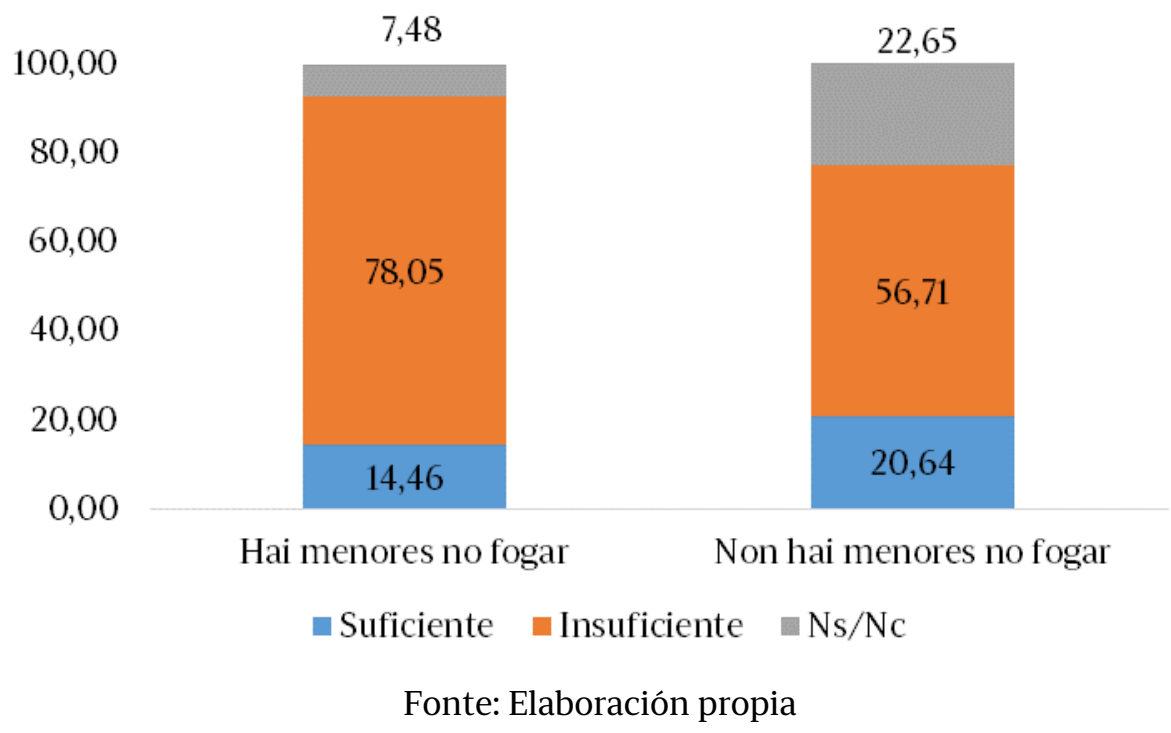

Tendo en conta os datos anteriores, resulta lóxico intuír que a variable de idade tamén vai influír na valoración da oferta de xogos en galego para menores de 16 anos. Deste xeito, pódese comprobar na seguinte gráfica que as persoas máis novas, as que se atopan na cohorte de entre 15 e 29 anos, son as xulgan escasa a oferta deste tipo de contidos culturais en maior proporción, concretamente un $89,9 \%$. Como acontecía cos outros contidos culturais analizados, esta porcentaxe vaise reducindo a medida que aumenta a idade, de tal xeito que son as persoas maiores de 65 anos as que mostran unha opinión menos negativa a este respecto, xa que menos da metade das persoas entrevistadas (un 46,37\%) consideran esta oferta escasa.

Oferta de xogos en galego para menores de 16 anos por idade

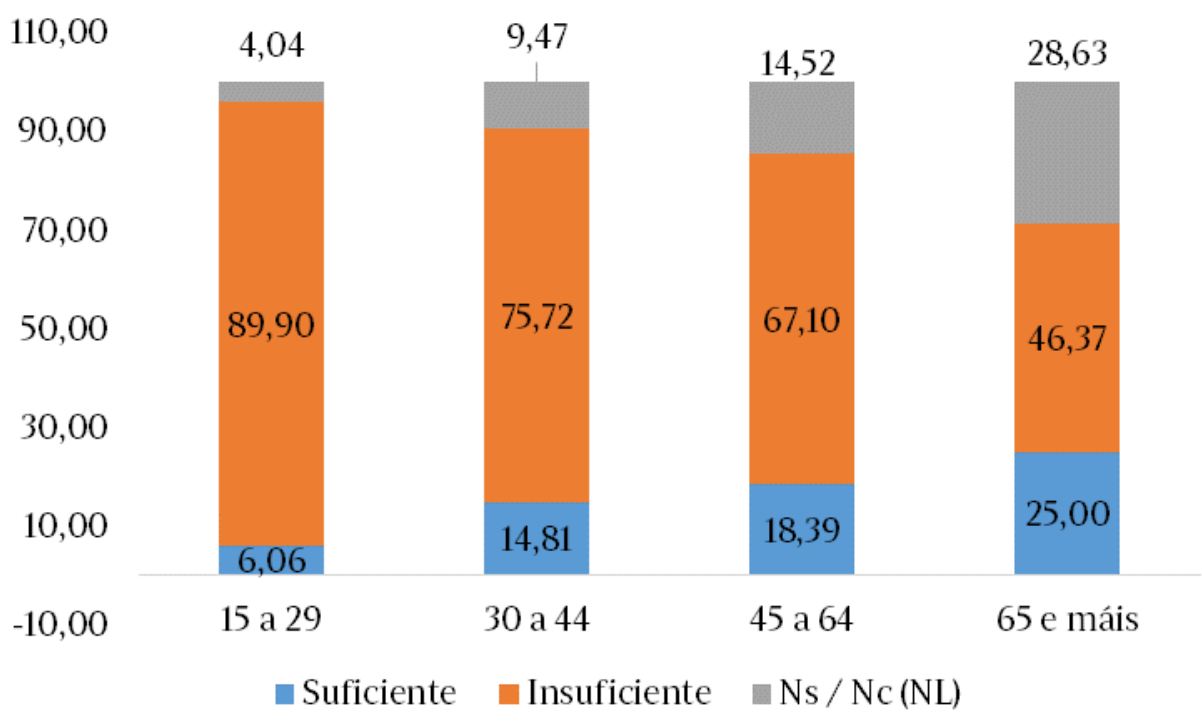

Fonte: Elaboración propia

Ao analizar os datos por nivel de estudos obsérvase que son as persoas con estudos universitarios superiores $(76,4 \%)$ e con estudos de Formación Profesional $(73,45 \%)$ as que consideran en maior medida que a oferta de xogos en galego 
é insuficiente. Chama a atención o elevado índice de persoas sen estudos $(69,23 \%)$ que non contestan ou non saben responder a esta pregunta.

Oferta de xogos en galego para menores de 16 anos por nivel de estudos

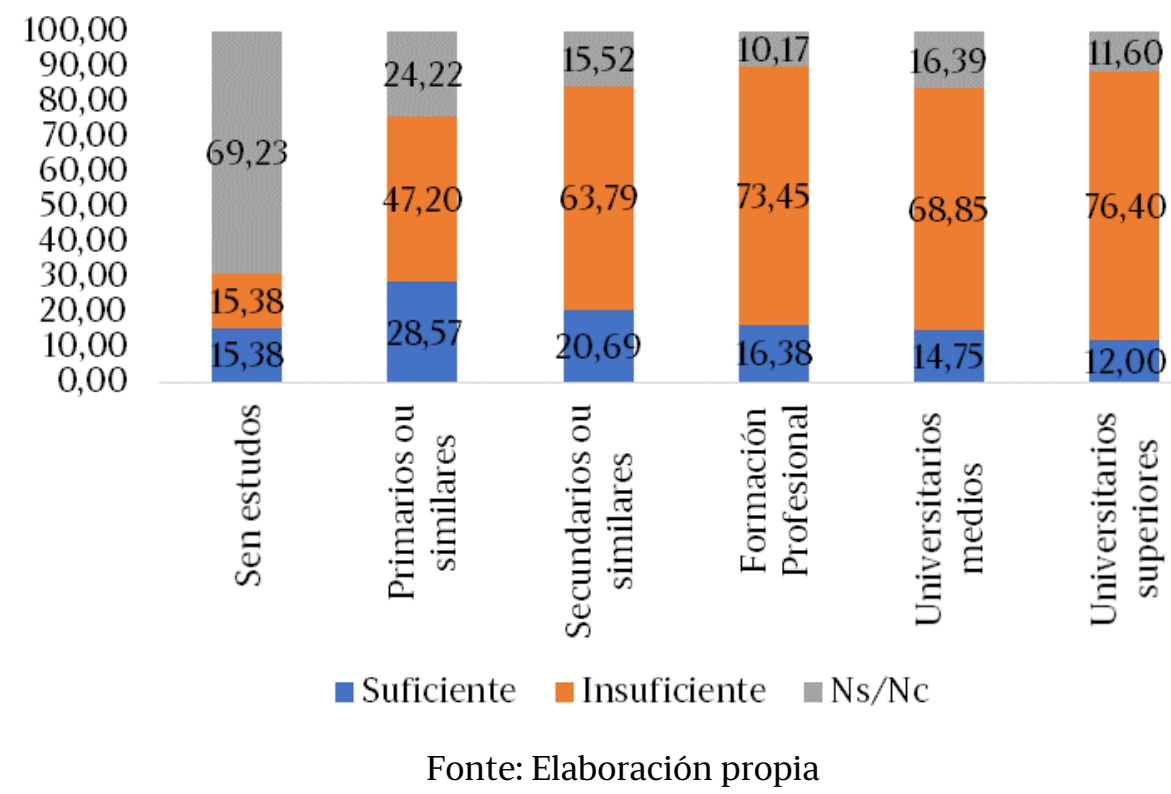

Por ocupación, domina claramente o grupo de estudantes, que nun $88,37 \%$ opina que esta oferta de contidos culturais é escasa, seguida das persoas que se atopan en activo, tanto as asalariadas como as autónomas.

Oferta de xogos en galego para menores de 16 anos por ocupación

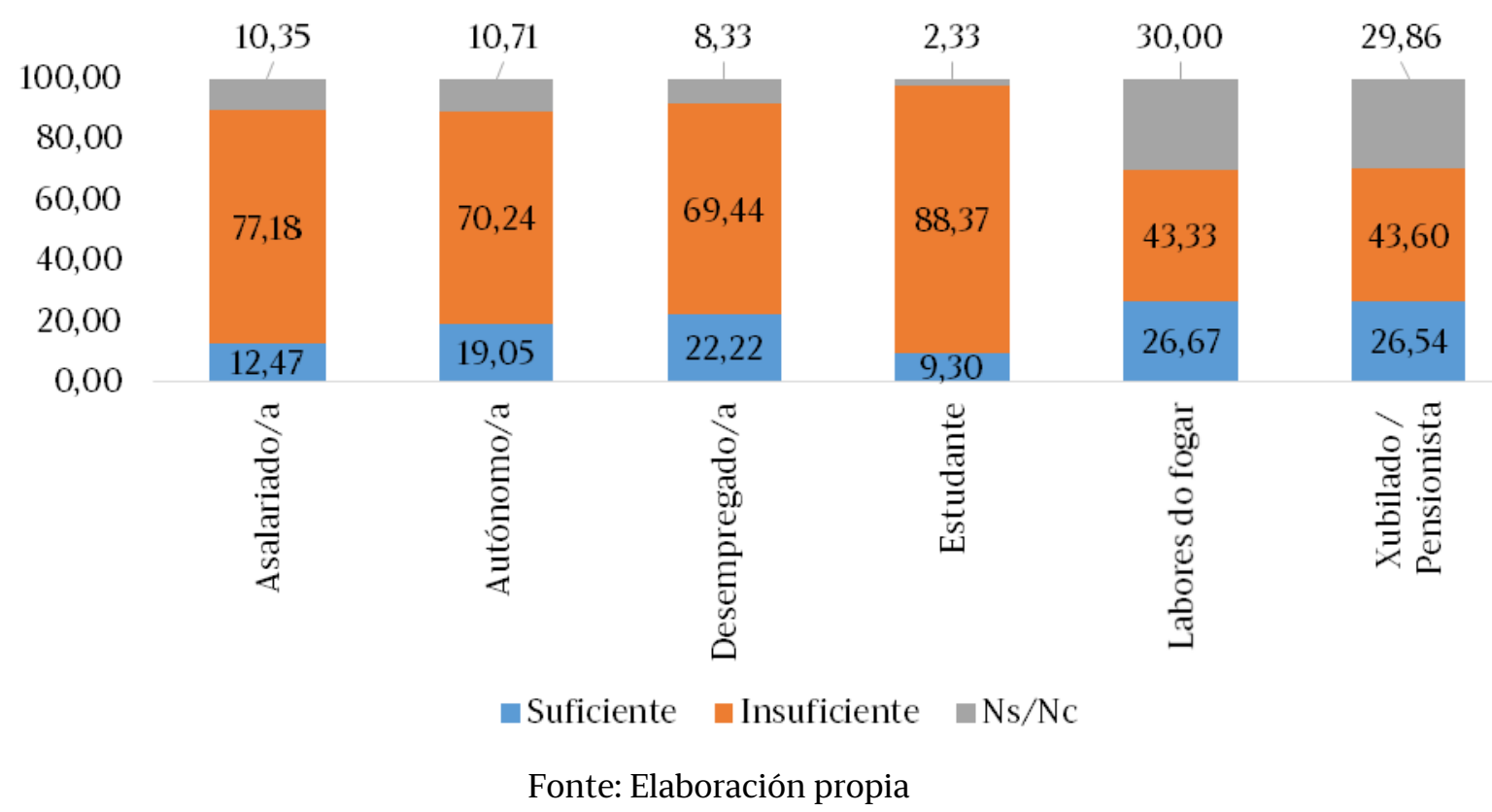

Por tipoloxía do contorno de residencia, pódese comprobar que son as persoas que viven en núcleos urbanos as que opinan en maior proporción (73,58\%) que a oferta de xogos en galego para menores de 16 anos é escasa. Neste caso non existe unha diferenza tan acusada entre as persoas que viven no contorno urbano e o rural, como acontecía coa oferta doutros produtos culturais. 
Oferta de xogos en galego para menores de 16 anos por tipoloxía de contorno de residencia

$$
\begin{array}{r}
100,00 \\
90,00 \\
80,00 \\
70,00 \\
60,00 \\
50,00 \\
40,00 \\
30,00 \\
20,00 \\
10,00 \\
0,00
\end{array}
$$

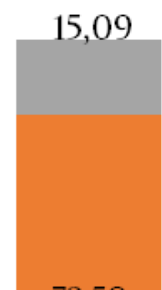

16,12

13,11

18,83
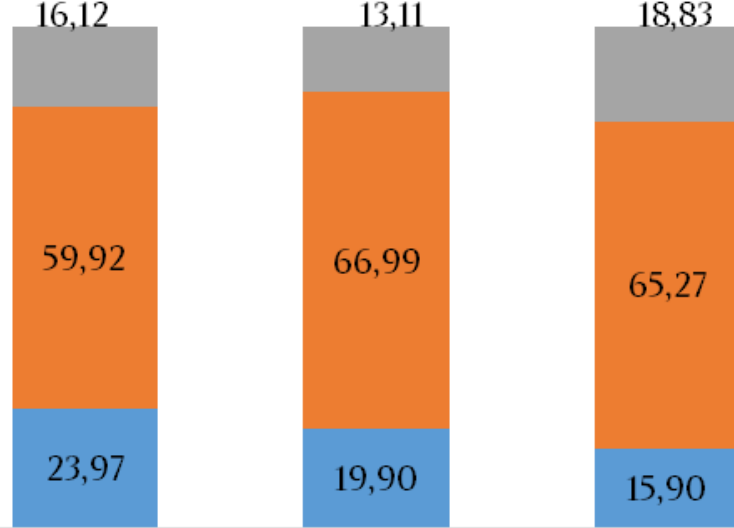

11,32

Vila pequena

Núcleo pequeno

Cidade grand

Vila mediana (periurbano) ou aldea (rural)

$\square$ Suficiente $\quad$ Insuficiente $\quad$ Ns/Nc

Fonte: Elaboración propia

Por último, tanto o grao alto de equipamento cultural no fogar como a subscrición a plataformas dixitais condicionan a opinión sobre a oferta escasa de xogos en galego para menores de 16 anos, que rexistran en ambos os casos taxas superiores ao $70 \%$.

\section{Oferta de xogos en galego para menores de 16 anos por grao de equipamento cultural no fogar}

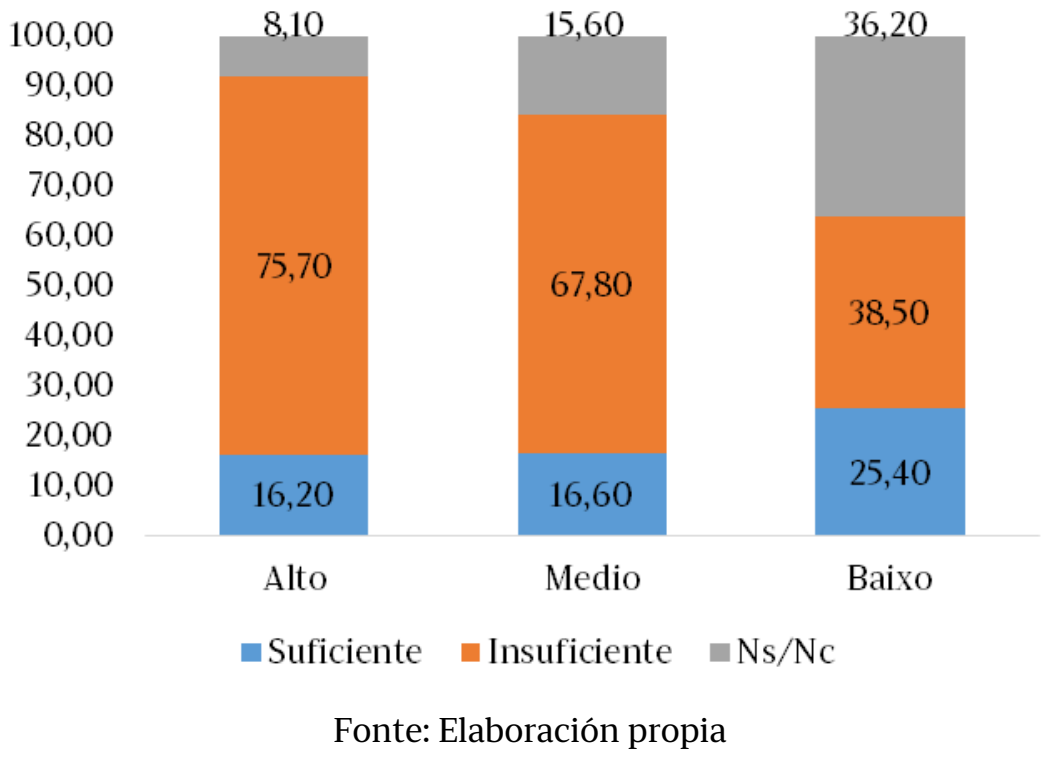




\section{Oferta de xogos en galego para menores de 16 anos por subscrición ou non a plataformas dixitais de contidos culturais}

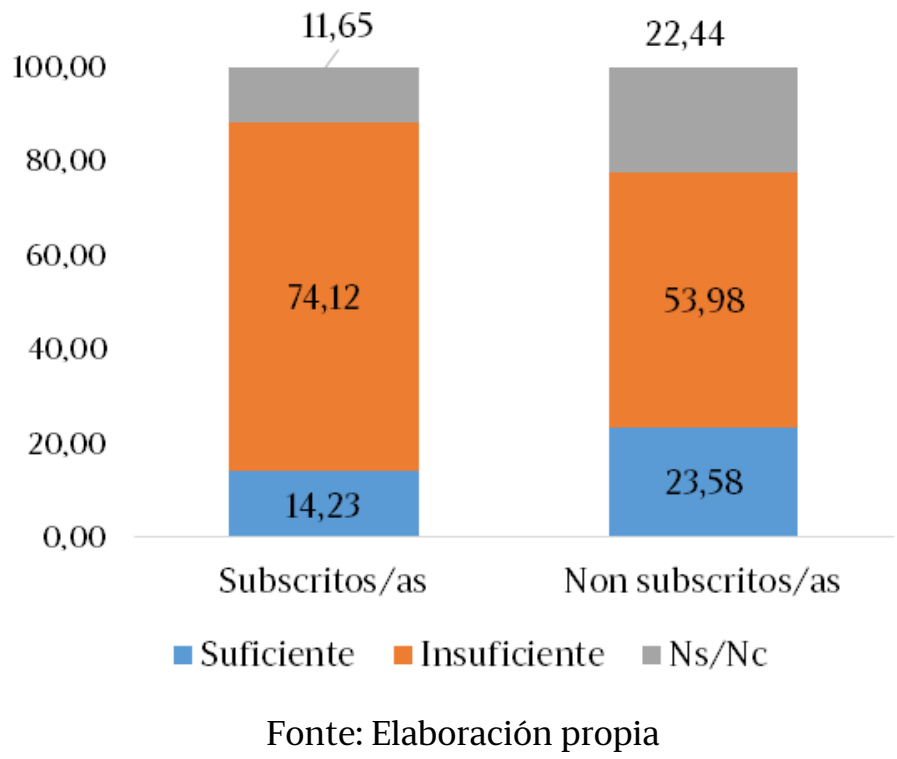

Entre a tipoloxía de xogos que botan en falta as persoas que afirmaron que a oferta era insuficiente mencionaron as seguintes categorías: xogos de mesa/tradicionais, videoxogos, xoguetes interactivos, xogos didácticos e educativos. Como se pode comprobar na seguinte gráfica, os máis demandados son os xogos de mesa/tradicionais $(36,24 \%)$ e en segundo lugar os videoxogos $(14,93 \%)$.

Tipoloxía de xogos en galego para menores de 16 anos que se botan en falta as persoas que consideran insuficiente esta oferta

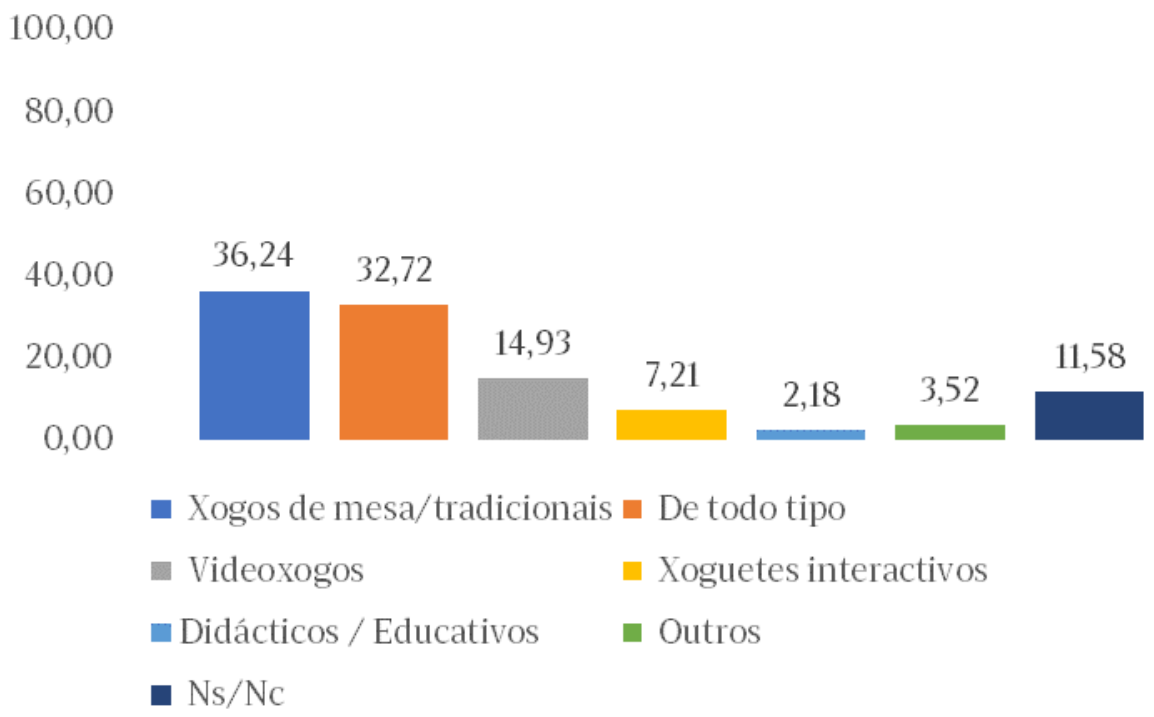

Fonte: Elaboración propia 


\section{CONSUMO DE CONTIDOS CULTURAIS ENTRE MENORES DE 16 ANOS}

Este apartado describe como é o consumo actual de contidos culturais das persoas menores de 16 anos dos fogares galegos, tanto en lingua galega coma noutros idiomas. Para isto analízanse os seguintes produtos culturais: libros, publicacións e revistas, espectáculos (teatro, danza, ballet, ópera, circo, contacontos, monicreques etc.), cine en sala, música, museos e exposicións, televisión, contidos audiovisuais (series, televisión á carta, canles de vídeo, cine etc.) e xogos (xogos de mesa, tradicionais, interactivos, vídeo xogos etc.).

En xeral ${ }^{8}$, os contidos cun consumo máis frecuente por parte de menores de 16 anos son a música $(70,8 \%)$, os libros $(68,6 \%)$, a televisión $(65,8 \%)$ e os contidos audiovisuais (60,6\%), pero en ningún dos casos en galego. De feito, tres dos produtos estudados en lingua galega non son consumidos nunca por unha alta porcentaxe dos rapaces e rapazas menores de 16 anos: un 91,5\% nunca vai ao cine en sala, un $88 \%$ non le revistas ou publicacións e un $73,1 \%$ non adquire xogos. En cambio, o libro en galego é utilizado ocasionalmente por un 40,1\% e frecuentemente por un 21,9\%. O mesmo sucede coa música neste idioma, un 41,9\% escóitaa ocasionalmente e un $35,2 \%$ con frecuencia.

Un $54,1 \%$ das persoas menores de 16 anos visita ocasionalmente museos ou exposicións de arte (42,1\% en galego), un 52,6\% asiste a espectáculos (44,6\% en galego) e máis da metade vai a salas de cine. O 46,4\% ve en ocasións a televisión en lingua galega, o 41,9\% le libros e o 40,1\% escoita musica tamén neste idioma.

A seguinte gráfica mostra unha comparativa do consumo de contidos culturais por parte de menores de 16 anos tanto en galego como en xeral.

\footnotetext{
${ }^{8}$ Non se presentan as porcentaxes obtidas da resposta "Non sabe, non contesta" para evitar confusións innecesarias, dada a escasa influencia desta contestación na xeneralidade dos resultados finais. Con todo, introducirase naqueles casos en que o índice porcentual sexa significativo e xustifique a pertinencia da súa inclusión.
} 


\section{Consumo actual de contidos culturais entre os menores de 16 anos}

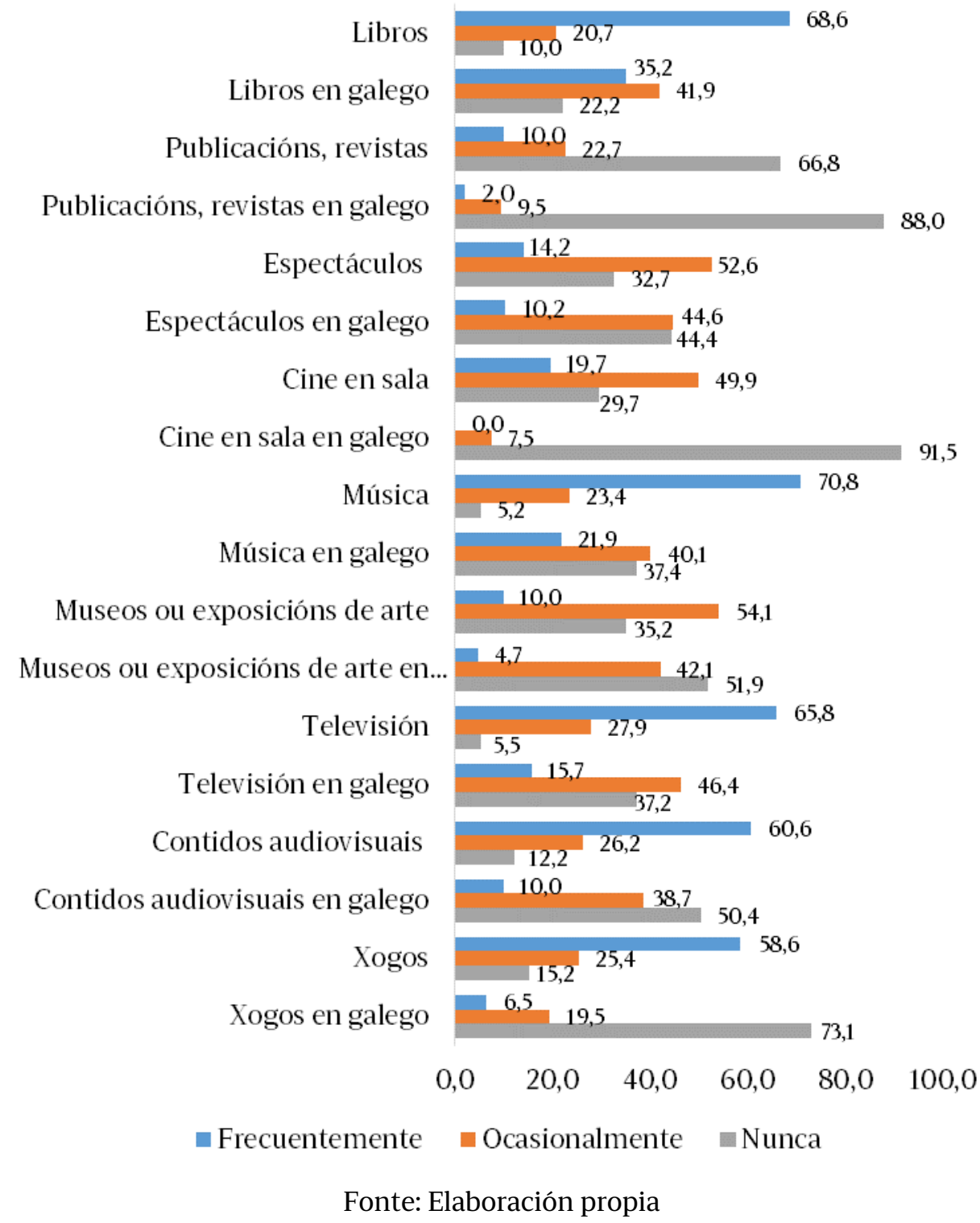

Pódese comprobar que existe unha relación entre os produtos culturais que se consideran máis escasos descritos no capítulo anterior dedicado á avaliación da oferta cultural en galego e a falta de consumo destes. É dicir, constátase que, en xeral, todos aqueles produtos cuxa oferta en lingua galega se considera máis escasa polas persoas entrevistadas son os que menos consome a rapazada, principalmente o cine en sala e os xogos en lingua galega. 


\subsection{LIBROS}

O libro é un dos produtos culturais máis consumidos por menores de 16 anos nos fogares das persoas entrevistadas. Fronte ao 68,6\% de quen le frecuentemente en calquera lingua, só un 35,2\% o fai en lingua galega, aínda que cabe mencionar que case un $41,90 \%$ si que o fai ocasionalmente.

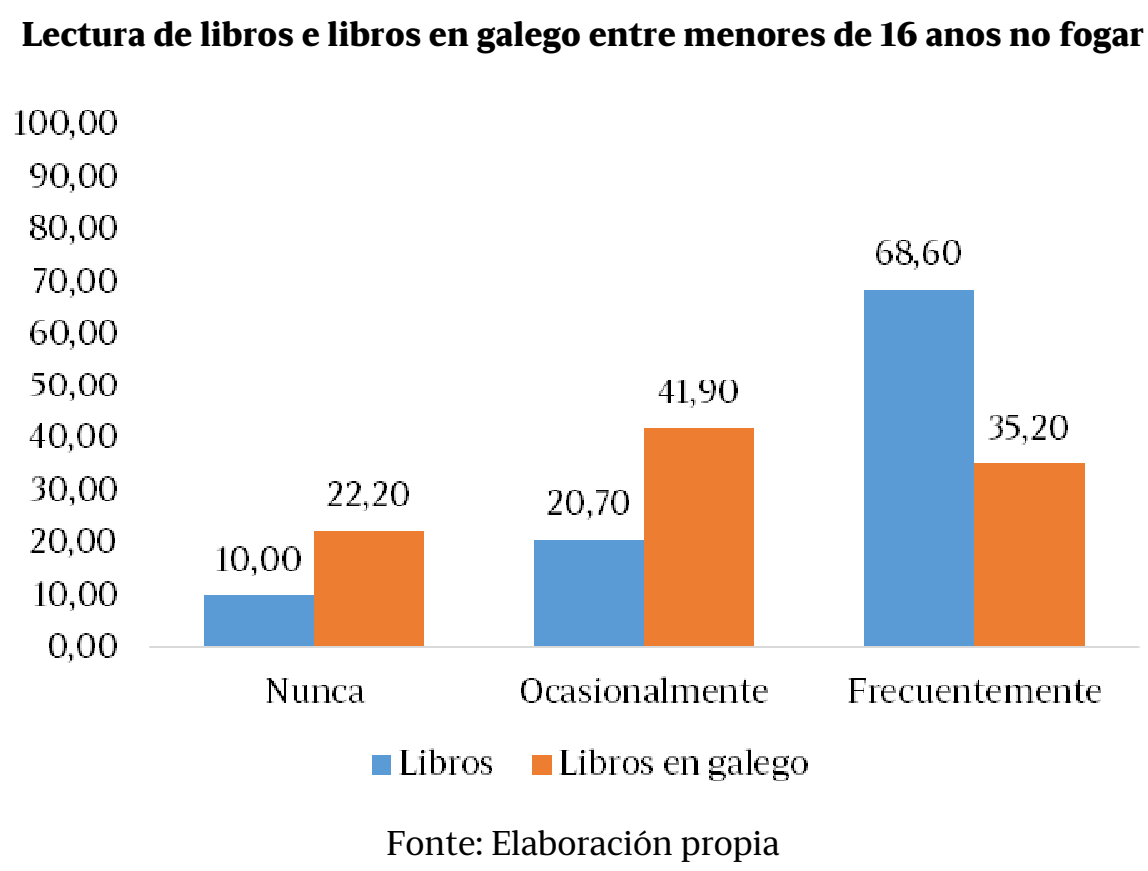

A partir destes datos xenéricos, analizouse a influencia de certas variables en relación coa lectura de libros. Os cruzamentos cos que se obtiveron diferenzas significativas foron: formación e ocupación das persoas enquisadas, asistencia a bibliotecas, lectura de libros e revistas, subscrición a plataformas dixitais de contidos culturais, contorno de residencia e lingua en que aprenderon a falar os fillos/as.

O nivel de formación das persoas entrevistadas afecta ao comportamento na lectura das persoas menores de 16 anos do fogar, xa que canto maior é o seu nivel formativo maior é a frecuencia coa que len libros: un 83,02\% no caso de quen conta con estudos universitarios medios e un $76,32 \%$ con estudos universitarios superiores. 


\section{Lectura de libros entre menores de 16 anos por nivel de estudos}

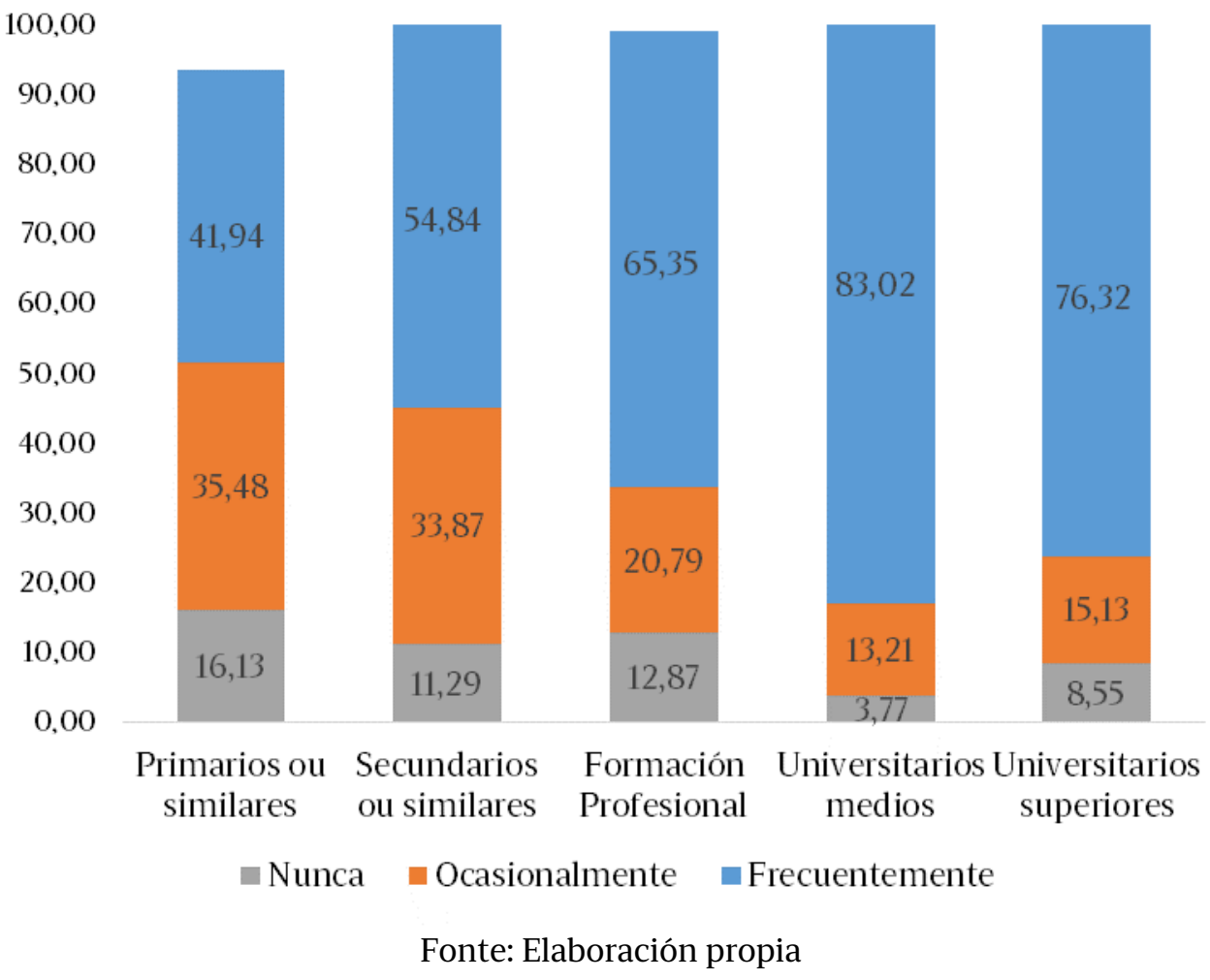

Ao analizar o hábito de lectura da rapazada segundo a ocupación das persoas entrevistadas, obsérvase que quen le con máis frecuencia son os menores que residen con asalariados $(73,29 \%)$, autónomos e cos/-as que desempeñan labores do fogar $(66,67 \%$ en ambos os dous casos). Nos fogares de estudantes a lectura ocasional da rapazada supera o 50\%, a porcentaxe máis elevada en relación co resto dos grupos.

\section{Lectura de libros entre os menores de 16 anos por ocupación}

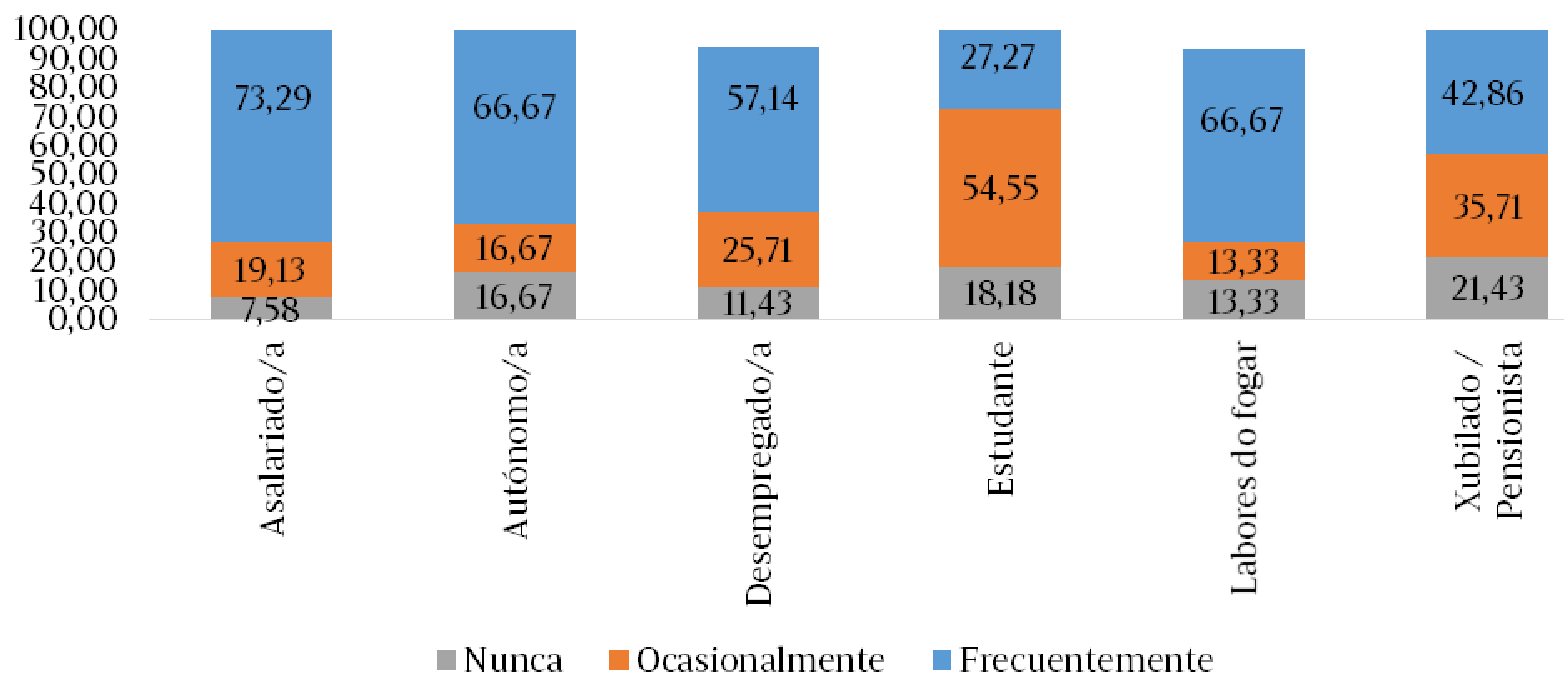

Fonte: Elaboración propia 
O feito de que as persoas entrevistadas lean con frecuencia libros non relacionados coa súa profesión ou estudos incide directamente na práctica da lectura dos nenos e nenas que residen no fogar. Un $76,7 \%$ da cativada que reside en fogares en que se le frecuentemente ten tamén este hábito. Esta porcentaxe vai descendendo cando se trata de persoas que len ocasionalmente libros non relacionados coa profesión ou os estudos ou nunca $(63,95 \%$ e $46,81 \%$ respectivamente).

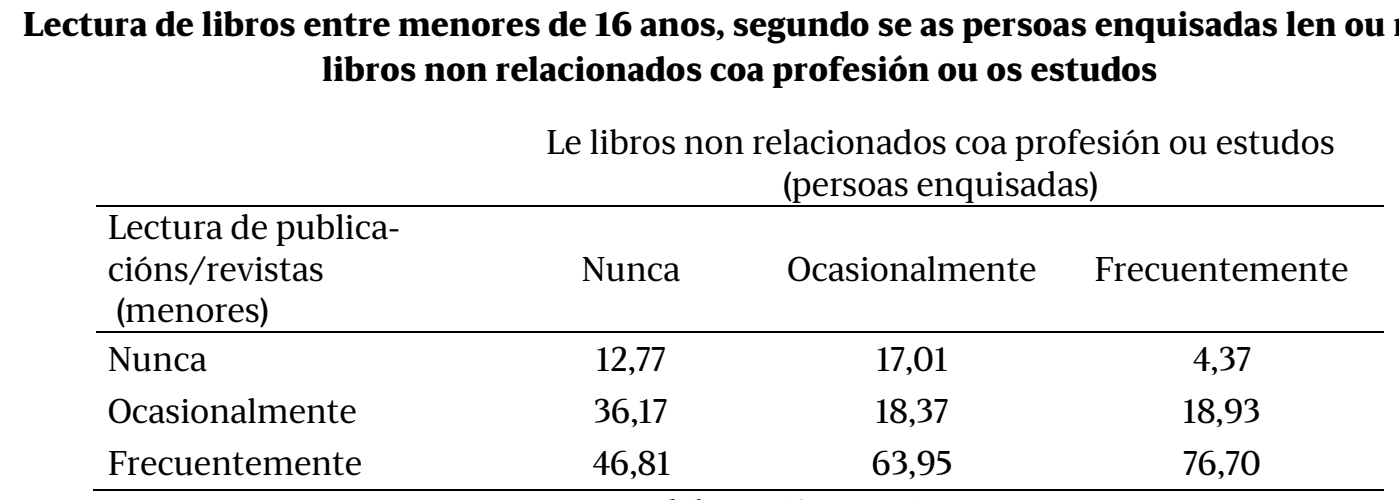

Fonte: Elaboración propia

O comportamento é practicamente idéntico cando se ten en conta se as persoas enquisadas len xornais ou revistas. Un 77,04\% de menores de 16 anos que residen en fogares en que se le frecuentemente este tipo de publicacións tamén le con frecuencia, 24 puntos porcentuais por riba de quen reside con lectores ocasionais ou con quen non le nunca. A porcentaxe de quen non le nunca revistas ou xornais baixa ata o $6,61 \%$ entre a rapazada que vive en fogares con persoas que len frecuentemente, como mostra a seguinte táboa.

\section{Lectura de libros entre os menores de 16 anos, segundo se as persoas enquisadas len xornais ou revistas}

Le libros non relacionados coa profesión ou estudos (persoas enquisadas)

\begin{tabular}{lccc}
\hline $\begin{array}{l}\text { Lectura de publica- } \\
\text { cións/revistas (meno- } \\
\text { res) }\end{array}$ & Nunca & Ocasionalmente & Frecuentemente \\
\hline Nunca & 14,29 & 16,52 & 6,61 \\
Ocasionalmente & 32,14 & 27,83 & 16,34 \\
Frecuentemente & 53,57 & 53,04 & 77,04 \\
\hline
\end{tabular}

Fonte: Elaboración propia

A seguinte variable considerada ten relación co tipo de contorno de residencia das persoas entrevistadas. A rapazada que reside en fogares situados en cidades grandes é a que le con máis frecuencia (un 75\%), seguido de cerca por quen reside en vilas pequenas $(74,44 \%)$. Un $18 \%$ de quen pertence a vilas de tamaño medio non le nunca, porcentaxe por riba do resto dos contornos. 


\section{Lectura de libros entre os menores de 16 anos segundo o contorno de residencia}

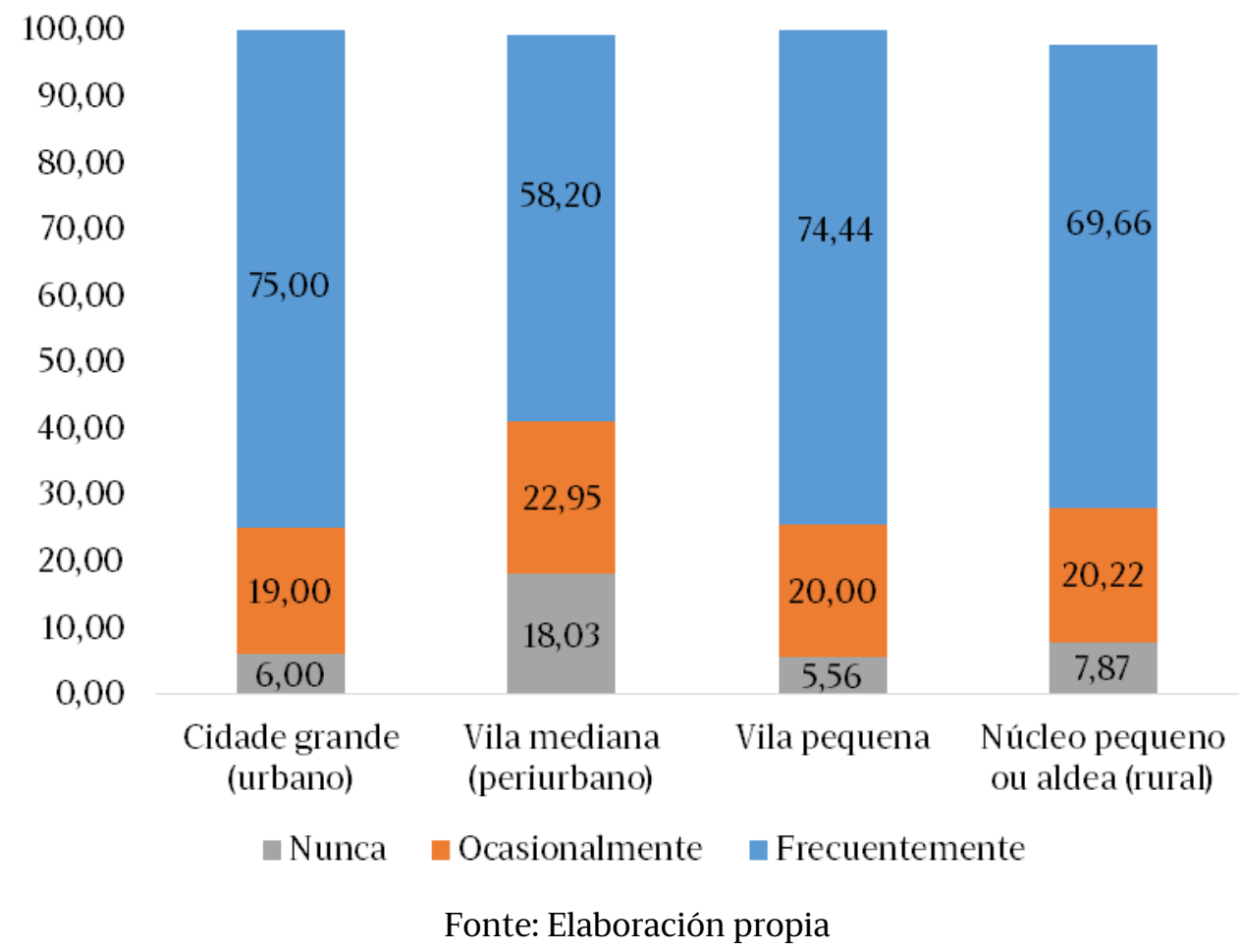

A lingua en que aprenderon a falar os fillos ou fillas das persoas entrevistadas repercute na frecuencia da lectura de libros, sobre todo no caso de galegofalantes, seguidos de quen fala noutros idiomas e bilingües $(77,97 \%, 73,33 \% \mathrm{e}$ $70,15 \%$ respectivamente). $O$ índice porcentual máis baixo de quen non le nunca correspóndelles ás persoas galegofalantes e castelanfalantes (6,78\% e 6,86\%).

\section{Lectura de libros entre os menores de 16 anos, segundo a lingua en que aprenderon a falar os fillos/as}

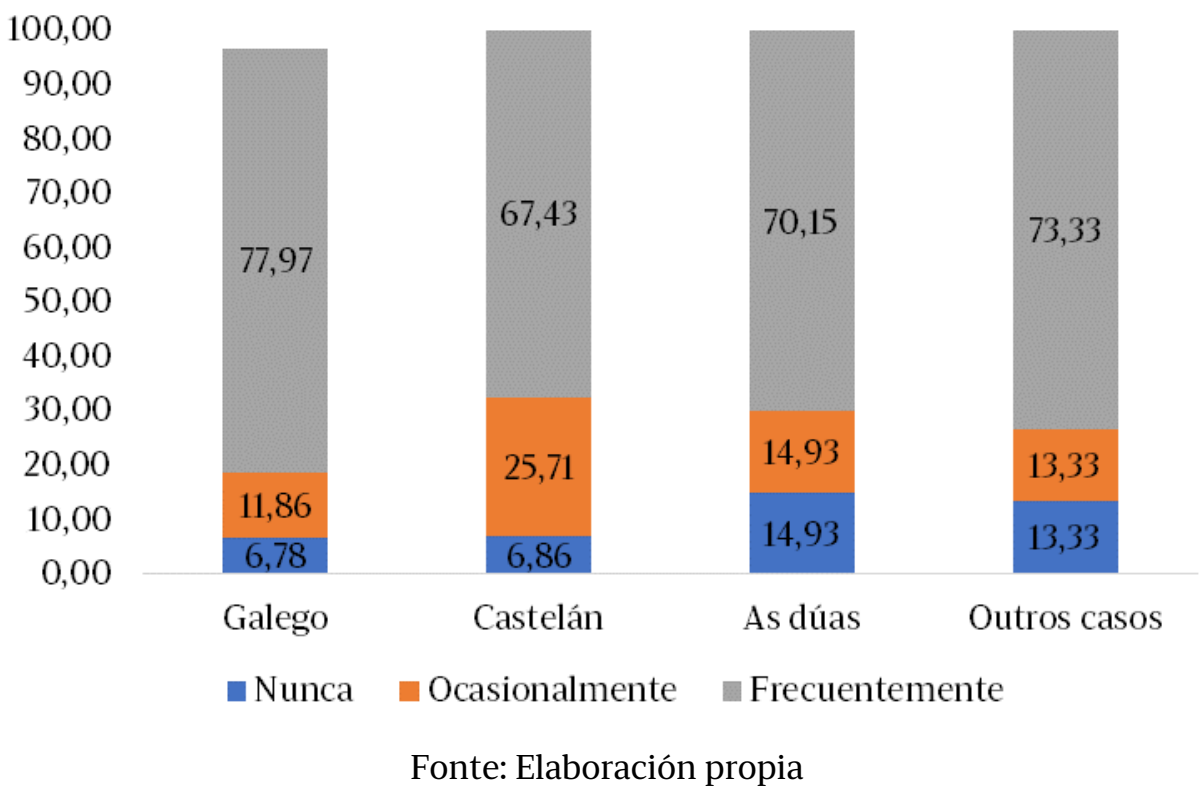

O hábito das persoas enquisadas de acudir ás bibliotecas tamén repercute na frecuencia de lectura de menores de 16 anos destes fogares. Un 78,4\% le frecuen- 
temente, porcentaxe que descende no caso de quen reside con persoas que só van ocasionalmente $(72,8 \%)$ ou nunca $(60,1 \%)$, como amosa a táboa que vai a continuación.

\section{Lectura de libros entre os menores de 16 anos, segundo se as persoas enquisadas van ás bibliotecas}

Le libros non relacionados coa profesión ou estudos (persoas enquisadas)

\begin{tabular}{lccc}
\hline $\begin{array}{l}\text { Lectura de publica- } \\
\text { cións/revistas (me- } \\
\text { nores) }\end{array}$ & Nunca & Ocasionalmente & Frecuentemente \\
\hline Nunca & 15,20 & 4,80 & 7,20 \\
Ocasionalmente & 23,60 & 21,60 & 14,40 \\
Frecuentemente & 60,10 & 72,80 & 78,40 \\
\hline
\end{tabular}

Fonte: Elaboración propia

Ao analizar a lectura de libros en lingua galega, compróbase que catro das seis variables que inflúen neste hábito coinciden coas que afectaban á lectura de libros en xeral, concretamente: a formación das persoas enquisadas, a asistencia desta ás bibliotecas, a lectura de libros e a lingua en que aprenderon a falar os fillos/as. Ademais, tamén repercuten de xeito significativo os ingresos das persoas entrevistadas e o nivel de equipamento do fogar en que reside a rapazada.

O nivel de estudos incide directamente na asiduidade coa que len libros en galego as persoas menores de 16 anos. Neste sentido, un 43,4\% de quen convive coas persoas entrevistadas que posúen estudos universitarios medios le frecuentemente, case 21 puntos porcentuais por riba de quen conta con estudos primarios ou similares. O mesmo sucede coas persoas que cursaron estudos universitarios superiores: un $42,11 \%$ de menores que residen nestes fogares le con frecuencia libros en lingua galega, fronte ao $22,58 \%$ e o $29,03 \%$ no caso dos fogares cuxos membros teñen estudos primarios e secundarios, respectivamente, nos que ademais se acadan os índices porcentuais máis elevados das persoas que non len nunca.

\section{Lectura de libros en galego entre menores de 16 anos segundo o nivel de estudos}

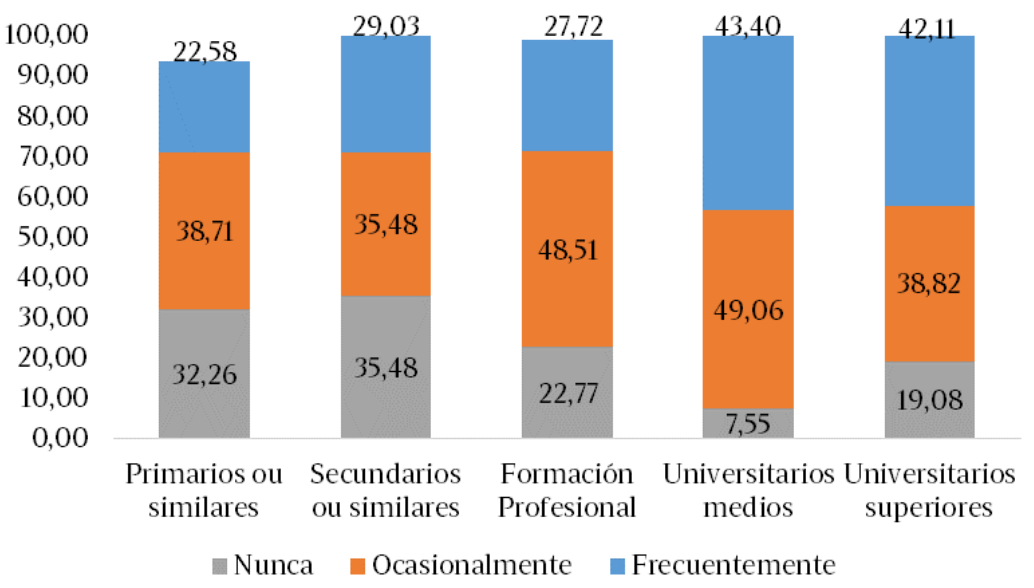

Fonte: Elaboración propia 
O nivel de equipamento cultural dos fogares tamén ten repercusión na lectura de libros en galego por parte da cativada: un $82 \%$ de quen reside en fogares cun alto nivel de equipamento le libros en galego, ou ben frecuentemente ou ocasionalmente. En cambio, a frecuencia na lectura de libros en lingua galega diminúe nos fogares con baixo equipamento cultural, xa que un 41,18\% non os le nunca.

\section{Lectura de libros en galego entre os menores de 16 anos, segundo o nivel de equipamento cultural no fogar}

$$
\begin{array}{r}
100,00 \\
90,00 \\
80,00 \\
70,00 \\
60,00 \\
50,00 \\
40,00 \\
30,00 \\
20,00 \\
10,00 \\
0,00
\end{array}
$$

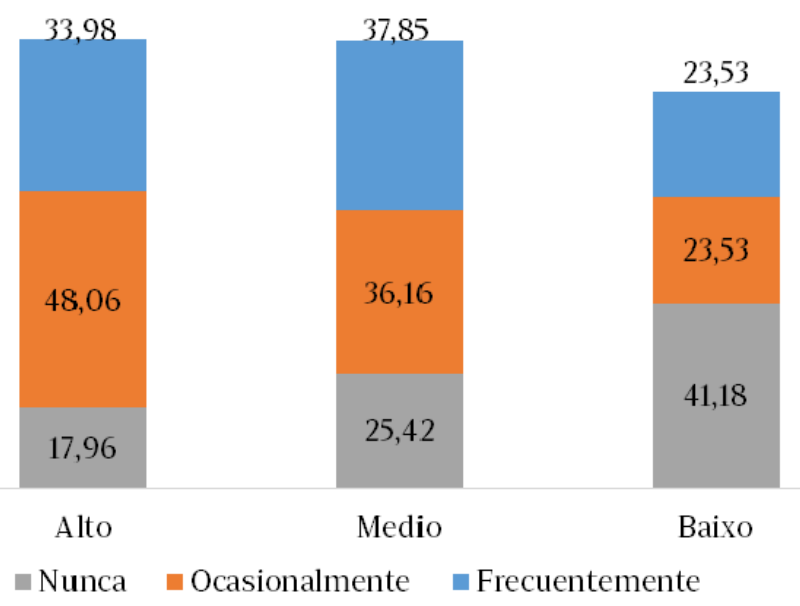

Fonte: Elaboración propia

Constátase igualmente que a porcentaxe de menores de 16 anos que le libros en galego aumenta segundo crece o nivel de ingresos das persoas entrevistadas. Un 53,06\% da rapazada le frecuentemente libros en lingua galega cando as rendas superan os 3.001 euros, seguidos polas de entre 2.001 e 3.000 euros (un $44,35 \%)$. Porén, nos fogares con ingresos por debaixo dos 1.000 euros, a cifra descende ata o 29,4\%, cunha porcentaxe moi significativa de quen non le nunca libros en galego (47,06\%). No grupo de persoas que declaran retribucións de entre 1.001 e 2.000 euros a lectura frecuente é practicada polo 30,36\% das persoas menores de 16 anos, a ocasional polo 42,86\% e máis da cuarta parte non le nunca libros en galego, como se pode observar na seguinte gráfica. 


\section{Lectura de libros en galego entre os menores de 16 anos, segundo o nivel de ingresos}

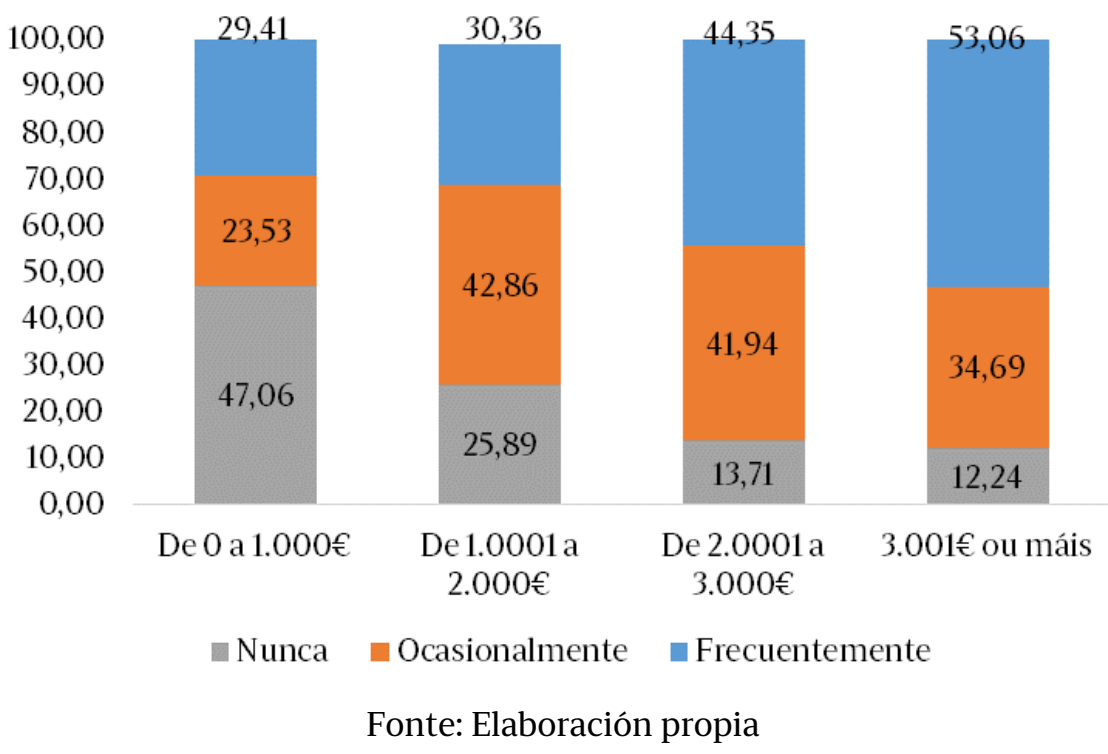

Se as persoas enquisadas acostuman ler frecuentemente libros non relacionados coa súa profesión ou estudos, os e as menores de 16 anos que viven no fogar tamén o fan en maior medida: un $43,7 \%$ fronte ao $28,6 \%$ no caso das persoas entrevistadas que o fan ocasionalmente e ao $17 \%$ de quen non le nunca este tipo de libros.

\section{Lectura de libros en galego entre menores de 16 anos, segundo se as persoas enquisadas len libros non relacionados coa profesión ou os estudos}

\begin{tabular}{lccc}
$\begin{array}{l}\text { Menores que len libros en } \\
\text { galego }\end{array}$ & Nunca & Ocasionalmente & Frecuentemente \\
\hline Nunca & 38,3 & 27,2 & 15,0 \\
Ocasionalmente & 40,4 & 43,5 & 41,3 \\
Frecuentemente & 17,0 & 28,6 & 43,7 \\
\hline
\end{tabular}

Fonte: Elaboración propia

A lingua en que as persoas enquisadas lles aprenderon a falar aos seus fillos e fillas inflúe na lectura de libros en galego por parte de menores de 16 anos. Máis da metade, un 50,85\%, da rapazada que aprendeu a falar en galego le libros en galego frecuentemente e só un $8,47 \%$ non o fai nunca. As persoas que aprenderon a falar en galego e en castelán e noutras linguas tamén manifestan índices significativos na frecuencia da lectura en galego, $43,28 \%$ e $46,67 \%$ respectivamente, pero neste último caso cunha porcentaxe moi elevada de quen non le libros en galego nunca (46,67\%). O índice máis baixo de lectura frecuente pertence a menores de 16 anos que aprenderon a falar só en castelán, un 25,14\%. 


\section{Lectura de libros en galego entre os menores de 16 anos segundo a lingua} en que aprenderon a falar

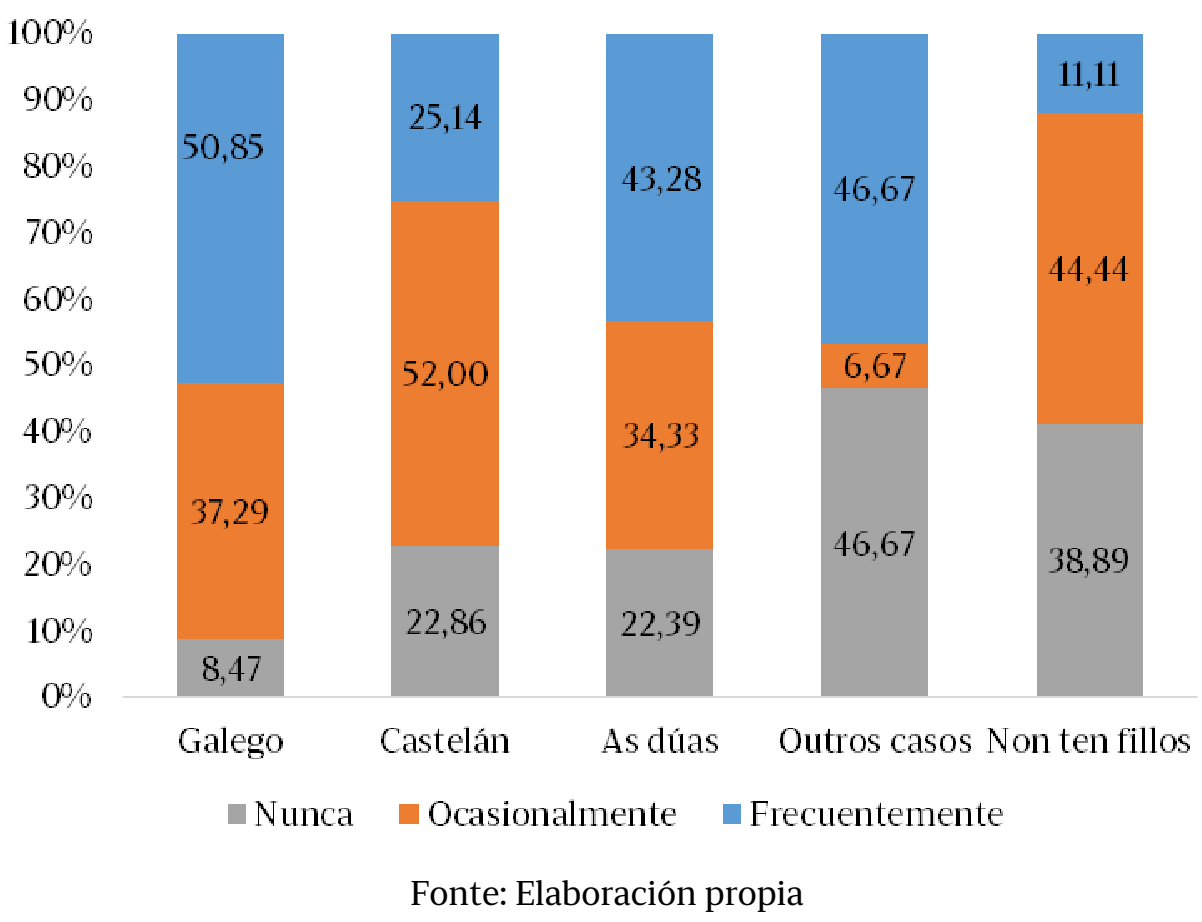

Do mesmo xeito que sucedía coa lectura de libros en xeral, a asistencia ás bibliotecas das persoas entrevistadas inflúe positivamente na lectura de libros en galego. Un $57,73 \%$ de menores que viven neses fogares le con frecuencia, fronte ao $23,6 \%$ de quen non vai nunca ou ao $33,6 \%$ de quen vai ocasionalmente. De feito, o índice máis elevado de menores que non len nunca libros en galego correspóndelle a quen reside coas persoas enquisadas que non van nunca ás bibliotecas, un 33,15\%.

\section{Lectura de libros en galego segundo se as persoas enquisadas van a bibliotecas}

Menores que len libros en

\begin{tabular}{lccc} 
galego & Nunca & Ocasionalmente & Frecuentemente \\
\hline Nunca & 33,15 & 13,60 & 13,40 \\
Ocasionalmente & 42,13 & 52,00 & 28,87 \\
Frecuentemente & 23,60 & 33,60 & 57,73 \\
\hline
\end{tabular}

Fonte: Elaboración propia 


\subsection{PUBLICACIÓNS E REVISTAS}

Unha alta porcentaxe de menores de 16 anos do fogar non le nunca publicacións e revistas en xeral, o 66,83\%, este índice porcentual aumenta case 22 puntos no caso da lectura en galego, un $88,03 \%$. Só un $2 \%$ da rapazada le con frecuencia este tipo de publicacións en galego, fronte ao 9,48\% que o fai en calquera outra lingua.

\section{Lectura de publicacións/revistas en galego entre menores de 16 anos no fogar}

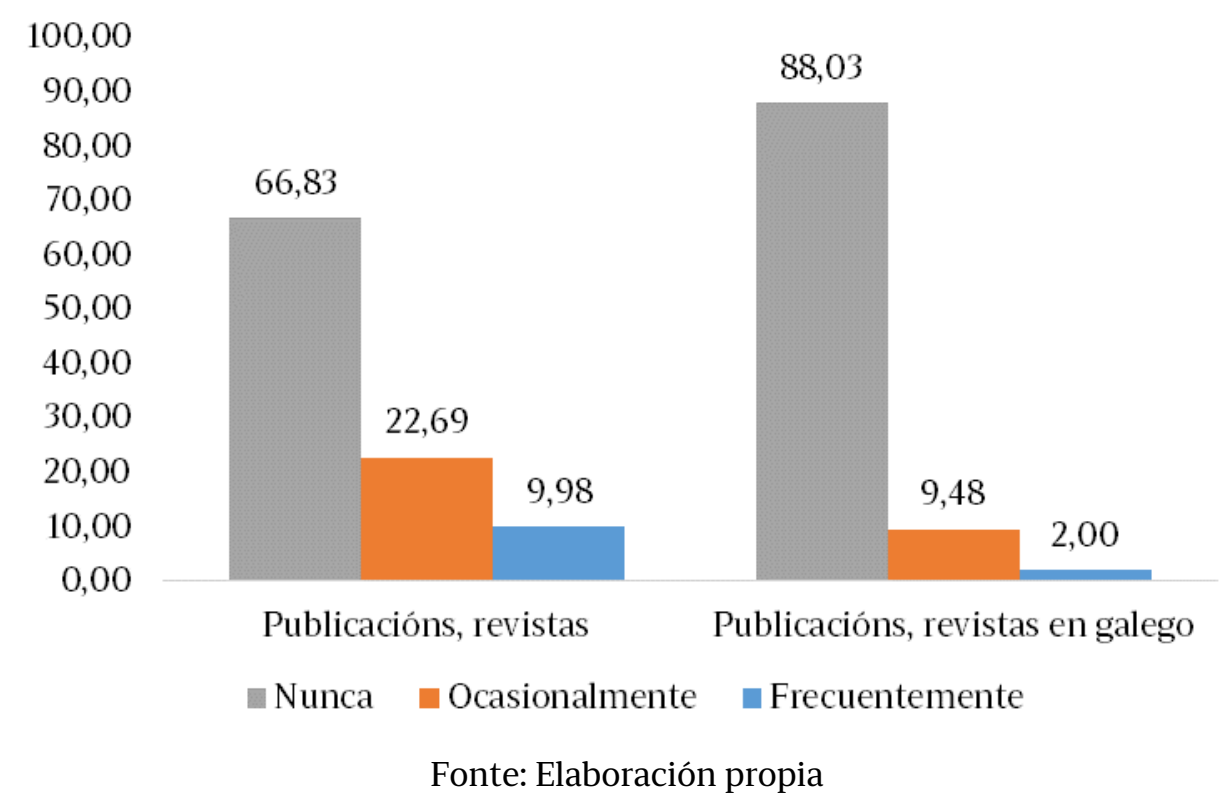

Tres son as variables que inflúen na lectura de publicacións e revistas en xeral: formación das persoas enquisadas, frecuencia coa que vai ás bibliotecas e lectura de libros non relacionados coa profesión.

A porcentaxe de persoas entrevistadas que responden que os menores non len nunca revistas ou publicacións diminúe segundo aumenta o seu nivel de estudos. É significativo o caso de quen posúe estudos universitarios medios, grupo en que este índice é 12,3 puntos menor que o de quen conta con estudos superiores (un 52,83\% e un 65,13\% respectivamente). Igualmente chaman a atención os índices de frecuencia de lectura entre menores que residen con persoas que posúen estudos primarios ou similares, fronte ás que teñen estudos universitarios superiores, unha diferenza porcentual de só 1,6 puntos $(12,9 \%$ fronte ao $14,47 \%)$. 


\section{Lectura de publicacións e revistas segundo os estudos das persoas enquisadas}

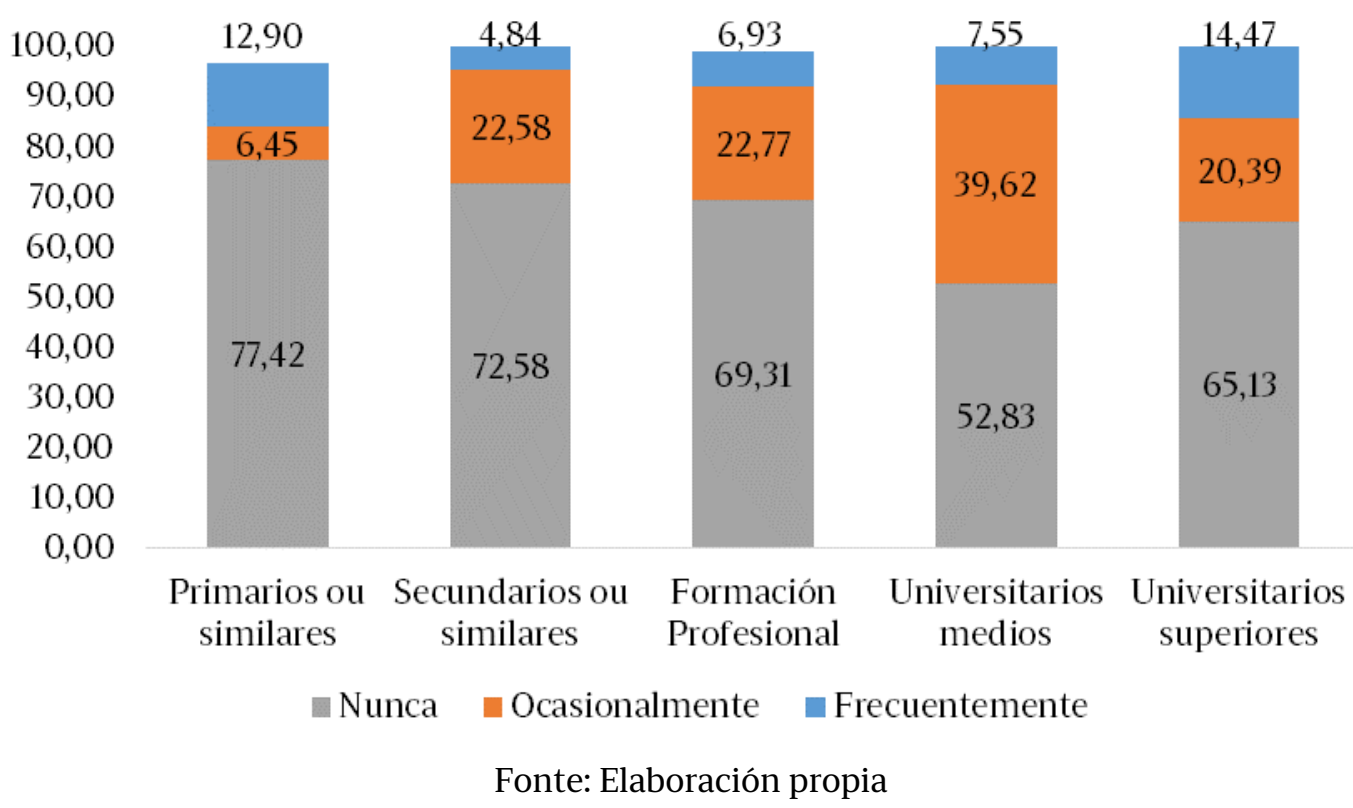

A asiduidade coa que as persoas enquisadas len libros alleos á súa profesión ou estudos inflúe na lectura de publicacións e revistas por parte de menores de 16 anos. En efecto, se as persoas entrevistadas responden que non len nunca, 0 $85,1 \%$ dos menores do fogar tampouco, un índice porcentual que baixa 19,8 puntos no caso dos que declaran ler ocasionalmente $(65,3 \%)$ e 21 puntos nos que manifestan ler frecuentemente este tipo de libros $(64,1 \%)$. A seguinte táboa dá conta dos resultados.

\section{Lectura de publicacións e revistas por parte dos menores de 16 anos do fogar, segundo se as persoas enquisadas len libros non relacionados coa profesión ou os estudos}

\begin{tabular}{lccc} 
& Le libros non relacionados coa profesión ou estudos \\
(persoas enquisadas) & \\
$\begin{array}{l}\text { Lectura de publica- } \\
\text { cións/revistas (menores) }\end{array}$ & Nunca & Ocasionalmente & Frecuentemente \\
\hline Frecuentemente & 6,4 & 6,8 & 13,1 \\
Ocasionalmente & 6,4 & 27,2 & 22,8 \\
Nunca & 85,1 & 65,3 & 64,1 \\
\hline
\end{tabular}

Fonte: Elaboración propia

O comportamento é moi similar cando se inclúe a variable de asistencia a bibliotecas por parte das persoas enquisadas. Case o $76 \%$ da cativada non le nunca publicacións e revistas cando os adultos contestan que non van nunca a bibliotecas, unha porcentaxe que baixa 11 puntos se a persoa entrevistada visita ocasionalmente as bibliotecas $(65,8 \%)$ e máis de 22 puntos porcentuais no caso de quen acode frecuentemente. A porcentaxe de rapaces que len con maior frecuencia publicacións e revistas, un 13,4\%, dáse no grupo de persoas enquisadas que van frecuentemente ás bibliotecas. 
Lectura de publicacións e revistas segundo se as persoas enquisadas van a bibliotecas

Lectura de publica-

Vai a bibliotecas (persoas enquisadas)

cións/revistas (menores)

Frecuentemente Nunca Ocasionalmente Frecuentemente

Ocasionalmente

7,3

11,2

13,4

Nunca

16,3

23,2

33,0

75,8

64,8

53,6

Fonte: Elaboración propia

Ao analizar a lectura de publicacións ou revistas en lingua galega, compróbase que a maior parte de menores de 16 anos non le nunca neste idioma. Con todo, a lingua habitual de expresión das persoas enquisadas sería a única variable que inflúe nesta práctica. Como se pode observar na seguinte gráfica, o grupo coa maior porcentaxe de rapaces que le ocasional ou frecuentemente publicacións e revistas en galego é o dos que adoitan falar máis galego que castelán, un $20,3 \%$ e un $4,1 \%$ respectivamente.

\section{Lectura de publicacións e revistas en galego segundo a lingua de expresión da persoas enquisadas}

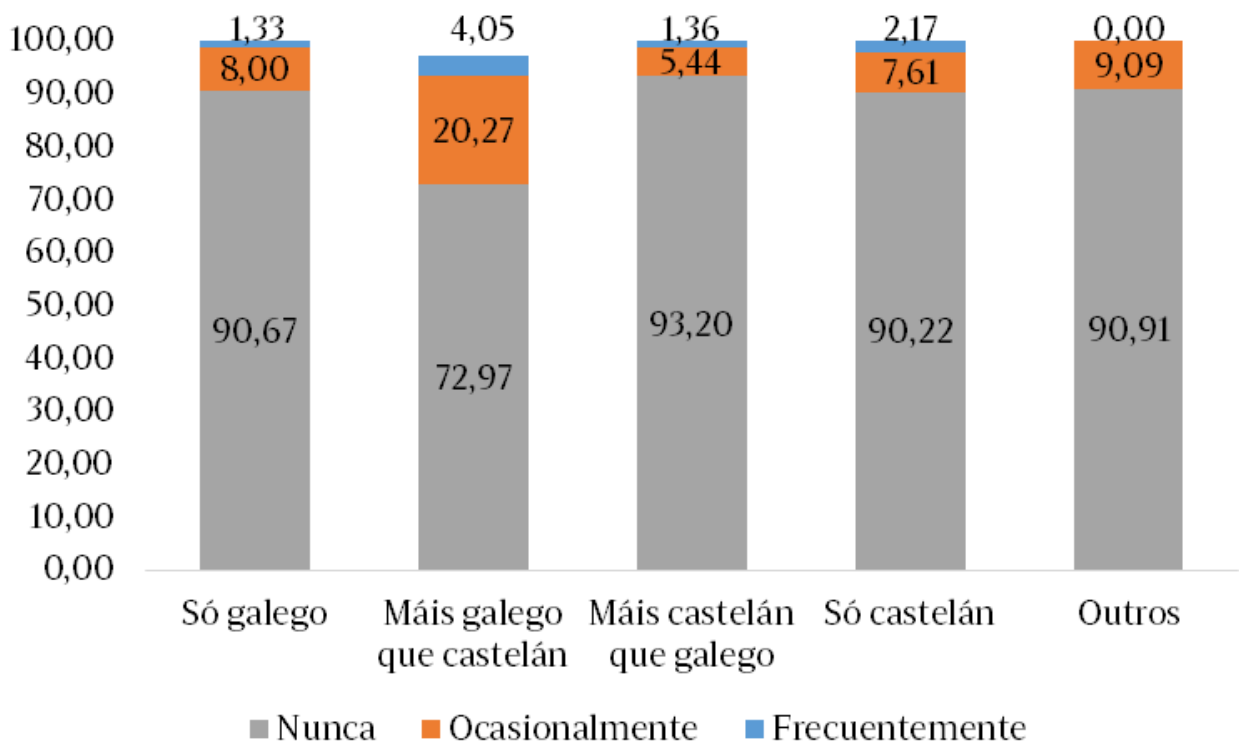

Fonte: Elaboración propia 


\subsection{MÚSICA}

Como se mencionaba anteriormente, a música é o contido cultural máis consumido polos menores de 16 anos: de feito, o 70,82\% escóitaa frecuentemente. A continuación analízase o consumo musical tendo en conta a influencia neste hábito de diferentes variables, como a ocupación das persoas enquisadas e a súa lingua habitual de expresión.

A escoita frecuente de música en galego, tal como mostra a seguinte gráfica, sitúase case 49 puntos porcentuais por debaixo do consumo de música en xeral. En cambio, un 40,15\% dos menores de 16 anos consúmea ocasionalmente $(16,7$ puntos máis en galego que en calquera outro idioma) e un 37,41\% nunca.

\section{Consumo de música e música en galego entre os menores de 16 anos do fogar}

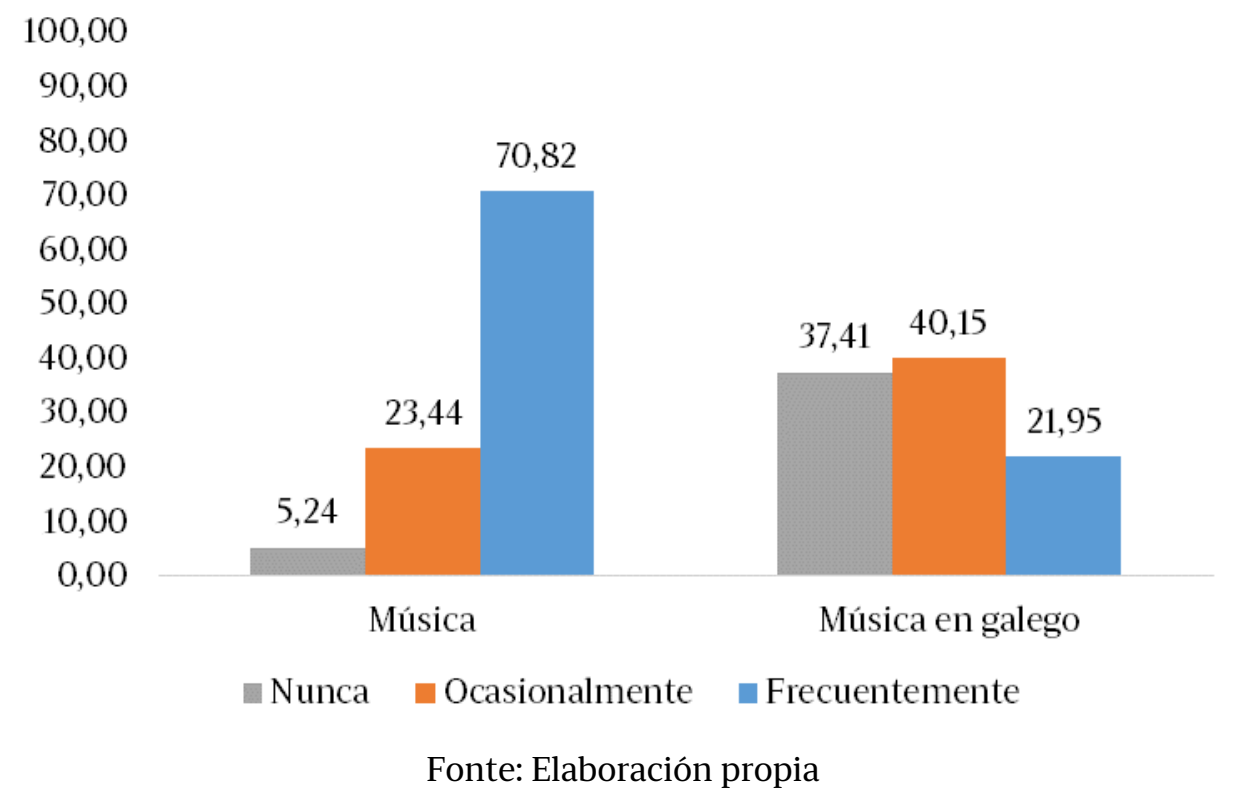

A escoita de música en xeral é máis alta entre os menores que conviven con persoas que contan con algún tipo de subscrición a plataformas de contido cultural: un 76,6\% (21,45\% frecuentemente), fronte ao 56,8\% de quen non conta con este tipo de ferramentas dixitais, dos cales un 42,11\% non adoita escoitar música nunca, como mostra a seguinte gráfica. 


\section{Consumo de música entre os menores de 16 anos segundo a subscrición} a algunha plataforma dixital de contido cultural

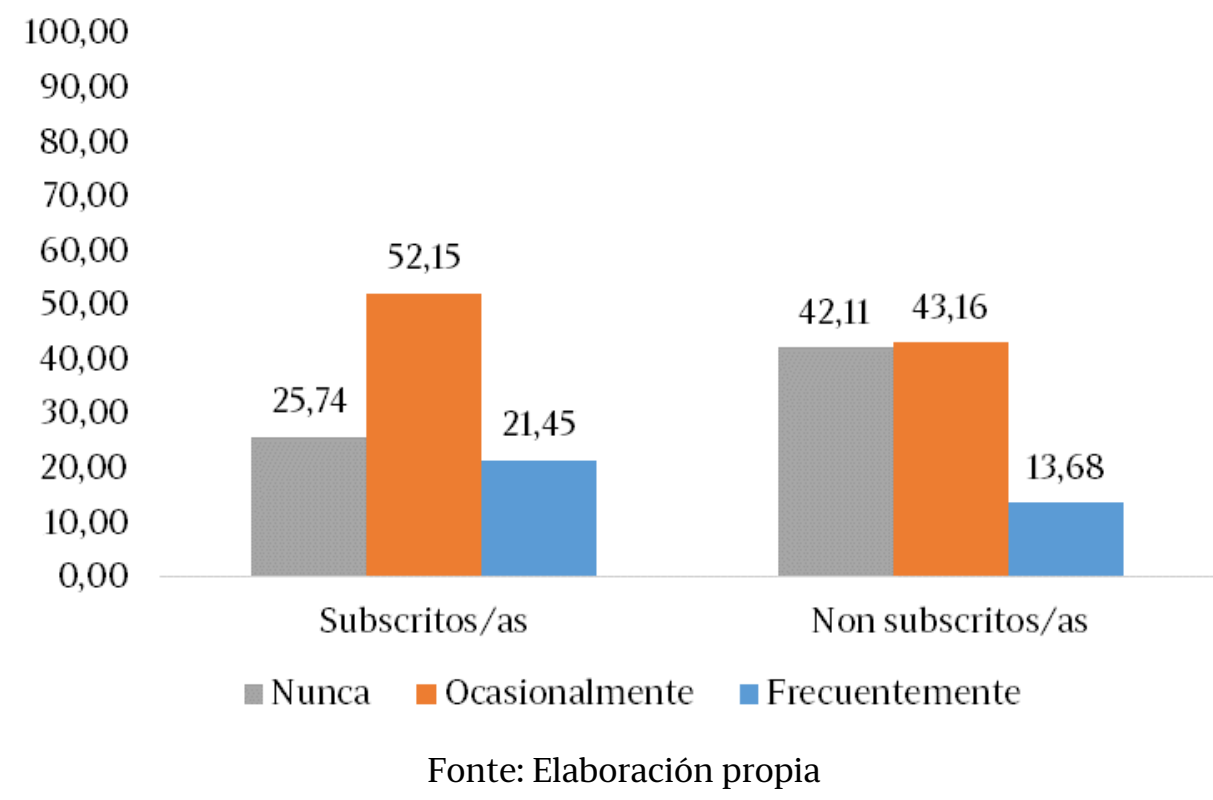

A información que se describe a continuación constata que a variable da ocupación das persoas enquisadas inflúe no consumo de música en galego. Deste xeito, os menores que viven en fogares en que as persoas entrevistadas son estudantes son as que escoitan música en galego con máis frecuencia (un $81,82 \%), 10$ puntos porcentuais por riba dos que residen con persoas xubiladas e desempregadas $(71,43 \%)$ e asalariadas $(70,76 \%)$.

\section{Consumo de música en galego entre os menores de 16 anos segundo} a ocupación das persoas enquisadas

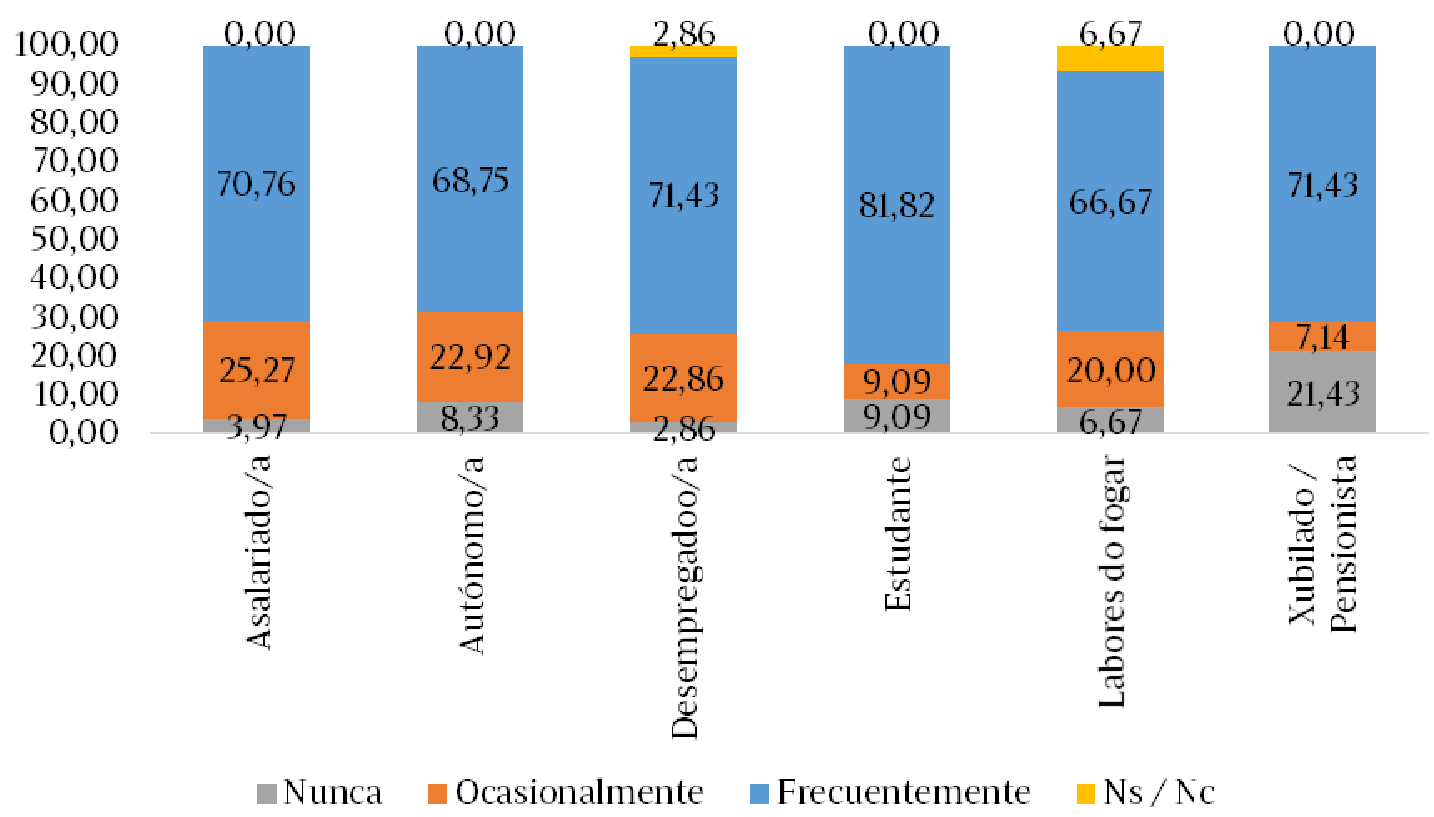

Fonte: Elaboración propia 
A lingua habitual de expresión das persoas entrevistadas repercute no consumo de música en galego por parte de menores de 16 anos que residen con eles. De feito, un 53,26\% de quen só fala castelán responde que os menores de 16 anos do fogar nunca escoitan música en galego, fronte ao $34,67 \%$ de quen só fala galego. As persoas que con máis frecuencia escoitan música en galego son por esta orde: as que conviven con adultos que só falan galego $(33,33 \%)$, as que utilizan máis galego que castelán (24,32\%) e as que usan máis castelán que galego $(20,41 \%)$, como se detalla na seguinte gráfica.

\section{Consumo de música en galego entre os menores de 16 anos segundo} a lingua habitual de expresión das persoas enquisadas

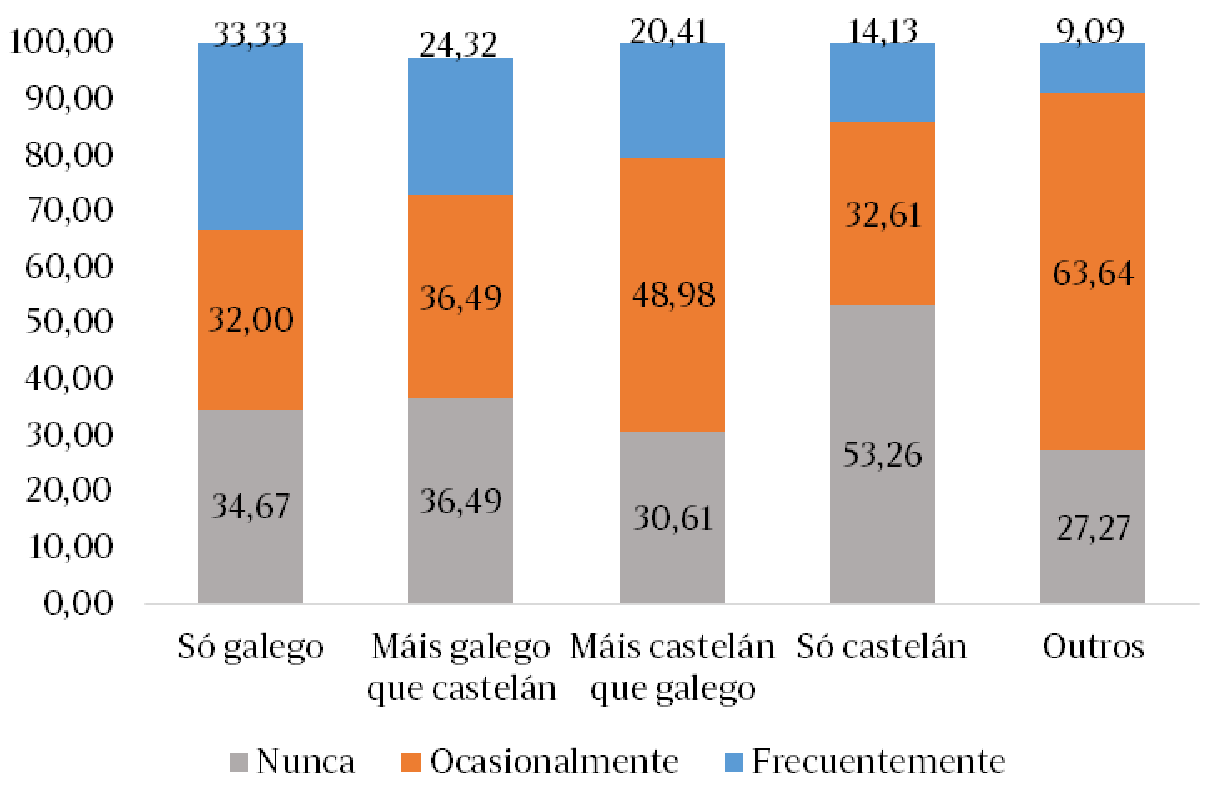

Fonte: Elaboración propia 


\subsection{ESPECTÁCULOS}

Un 66,8\% da rapazada vai a espectáculos (teatro, danza, ballet, ópera, circo, contacontos, monicreques etc.) ou ben ocasionalmente, ou ben frecuentemente, asistencia que mingua 12 puntos porcentuais cando se trata de programas específicos en galego $(54,8 \%)$, con cotas de frecuencia moi baixas en ambos os dous casos (14,2\% espectáculos en xeral e 10,2\% en lingua galega).

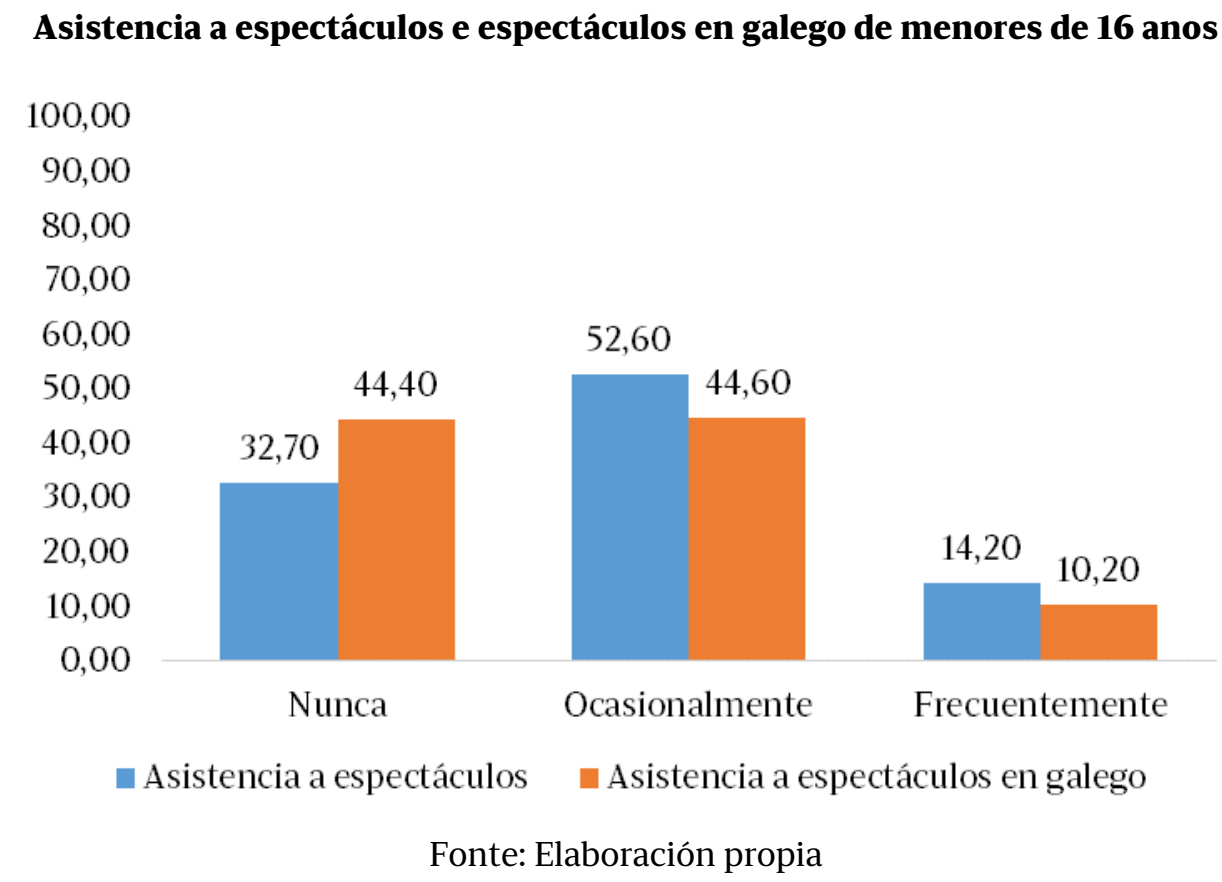

Na participación da rapazada neste tipo de actividade cultural inflúen fundamentalmente sete variables: o nivel de estudos, a posible subscrición a plataformas de contido cultural, a lingua habitual de expresión, a asistencia ao teatro, circo e contacontos, o nivel de ingresos do fogar, a asistencia a concertos de música e a provincia de residencia.

A partir dos resultados extraídos, pódese concluír que canto maior é o nivel de estudos das persoas enquisadas aumenta a asistencia de menores de 16 anos a espectáculos: un 43\% dos menores que conviven con persoas que contan con estudos universitarios acoden a espectáculos frecuentemente, máis de 33 puntos porcentuais por riba das persoas que cursaron estudos primarios, secundarios ou similares $(9,7 \%)$, como se aprecia na gráfica que vai a continuación. 
Asistencia de menores de 16 a espectáculos por nivel de estudos das persoas enquisadas

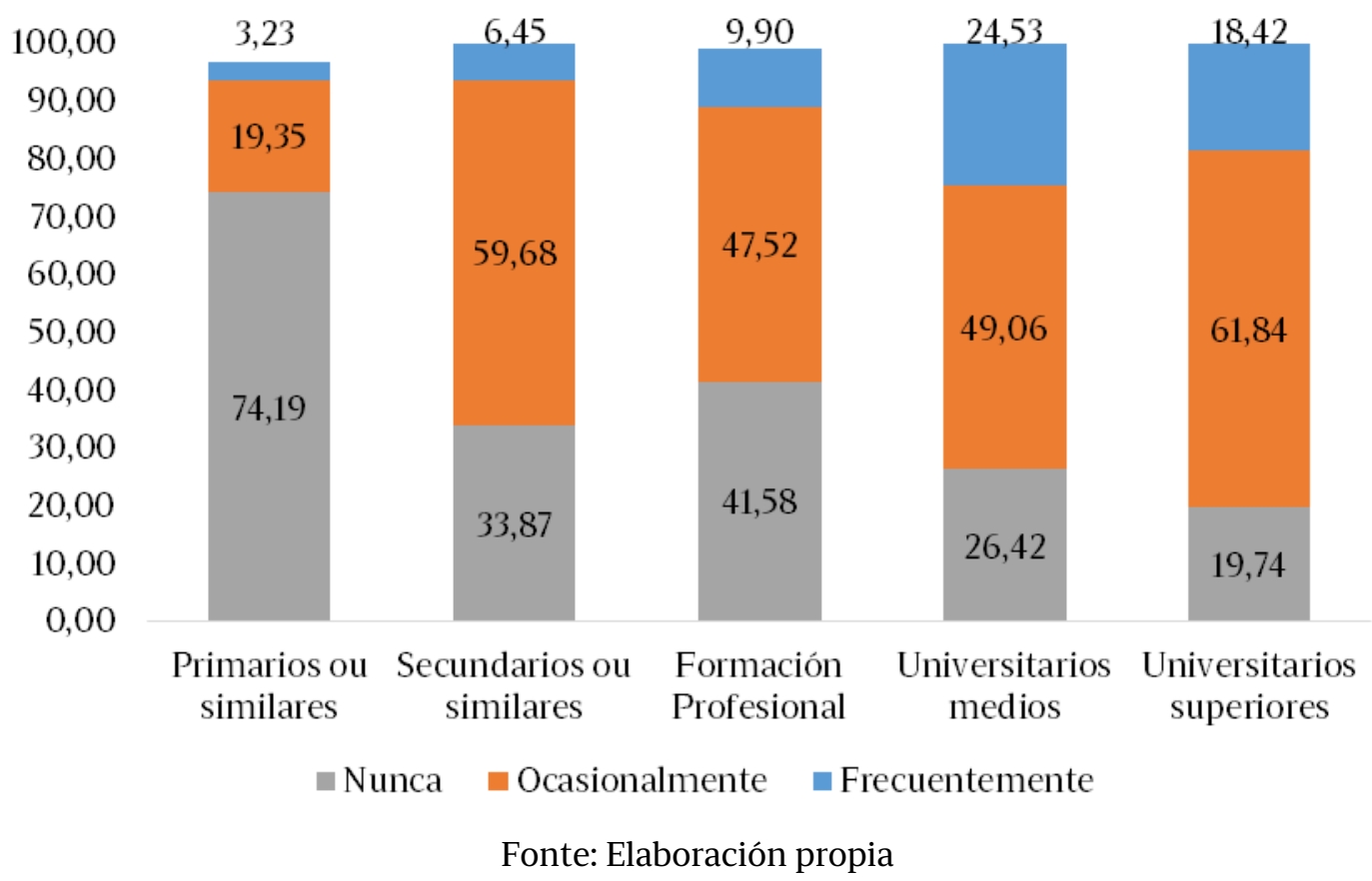

O 15,84\% dos menores que conviven con persoas subscritas a plataformas de contido cultural acoden con frecuencia a espectáculos e o 55,12\% fano ocasionalmente. No caso de que carezan deste tipo ferramentas dixitais no fogar, un $45,3 \%$ non asiste nunca e a porcentaxe de quen acode con frecuencia diminúe 6,4 puntos respecto aos primeiros.

Asistencia de menores de 16 anos a espectáculos segundo as persoas enquisadas estean ou non subscritas a algunha plataforma dixital de contido cultural

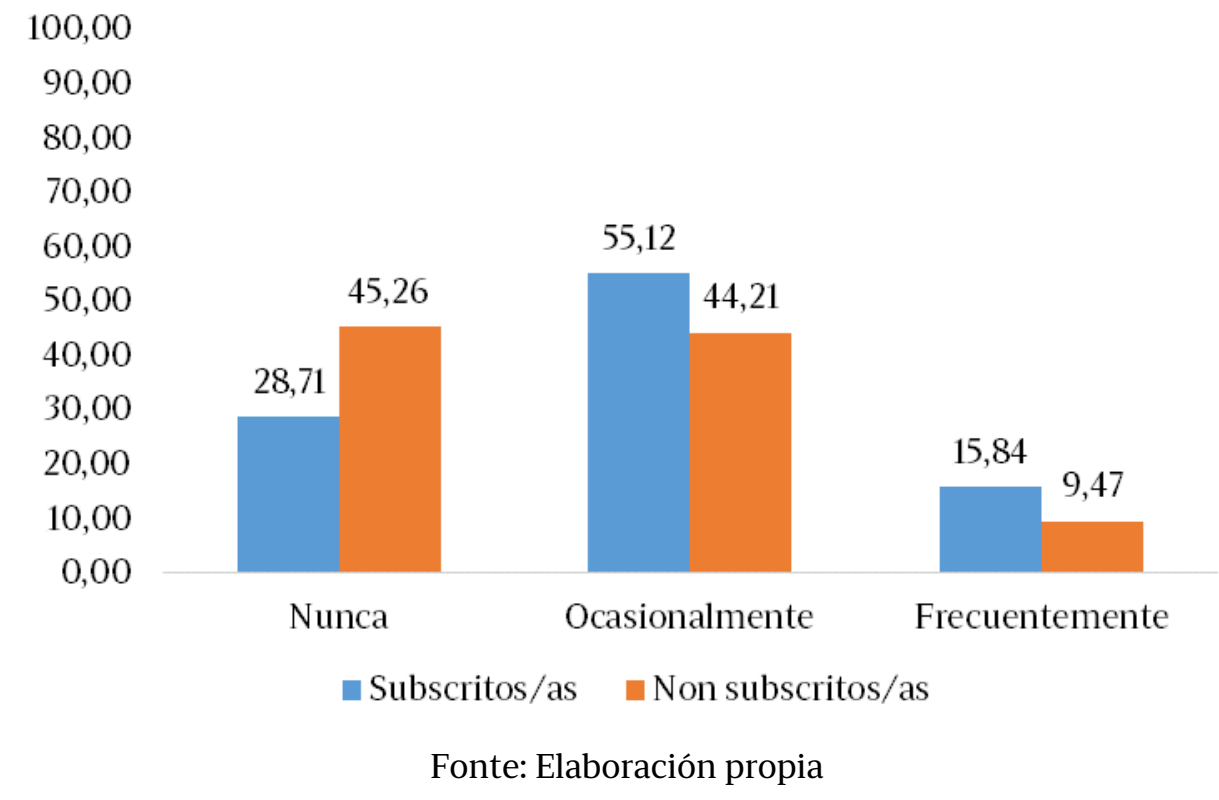

A lingua de expresión habitual da persoa entrevistada inflúe na asistencia de menores de 16 anos aos espectáculos. Así, as persoas que conviven con adultos que falan máis castelán que galego son as que rexistran a porcentaxe máis elevada $(18,37 \%)$, seguido das que só falan castelán $(15,22 \%)$ e as que só falan galego 
$(10,67 \%)$. Con todo, este último grupo, xunto co das persoas que falan outras linguas, son os que menos acoden a este tipo de eventos culturais: un $48 \%$ e un $45,45 \%$ respectivamente non vai nunca.

\section{Asistencia de menores de 16 anos a espectáculos por lingua de expresión das persoas entrevistadas}

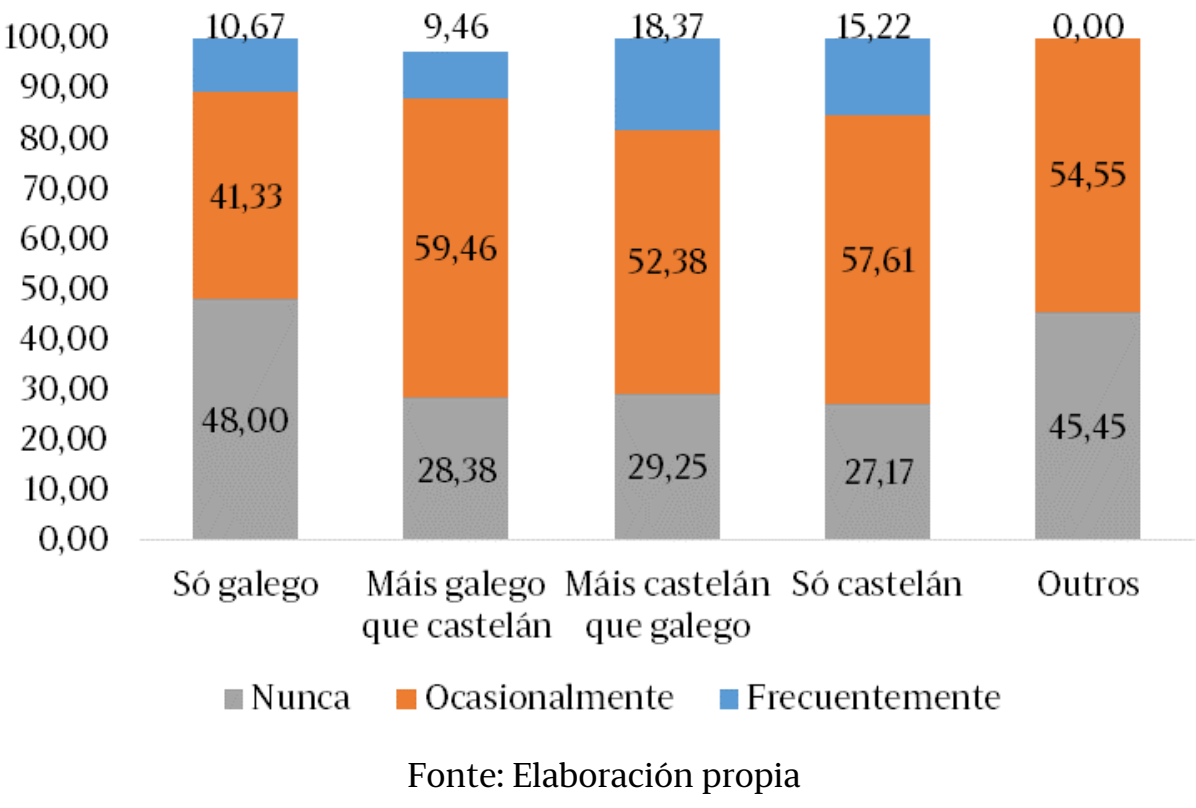

Outra das conclusións que se pode extraer deste estudo é que, canto máis acoden as persoas enquisadas ao teatro, ao circo ou a funcións de contacontos, aumenta a asiduidade coa que van os menores. De feito, máis da metade asiste frecuentemente $(50,9 \%)$, case 45 puntos por riba dos que conviven con persoas que non realizan nunca este tipo de actividades culturais (un 5,9\%). A seguinte táboa dá conta desta influencia.

Asistencia de menores de 16 anos a espectáculos segundo se as persoas enquisadas van ao teatro, circo ou contacontos

\begin{tabular}{lccc}
\multirow{2}{*}{$\begin{array}{l}\text { Asisten a espectáculos (me- } \\
\text { nores) }\end{array}$} & Nunca & Ocasionalmente & Frecuentemente \\
\hline Nunca & 56,3 & 23,9 & 8,5 \\
Ocasionalmente & 37,8 & 65,9 & 40,7 \\
Frecuentemente & 5,9 & 9,3 & 50,9 \\
\hline
\end{tabular}

Fonte: Elaboración propia

Este comportamento é moi similar cando se avalía o influxo da asistencia da persoa entrevistada a concertos de música co costume da rapazada de asistir a espectáculos. De feito, un $82 \%$ dos que conviven con adultos que van a concertos asiste a espectáculos ( $41 \%$ de forma frecuente e $41 \%$ ocasionalmente) e só un $18 \%$ non o fai nunca. En cambio, este índice descende en máis de 30 puntos porcentuais entre menores que residen con adultos que non van nunca a concertos de música. 


\section{Asistencia de menores de 16 anos a espectáculos segundo se as persoas enquisadas van a concertos de música}

Asisten a espectáculos (meno-
res)

Van a concertos de música (persoas enquisadas)

\begin{tabular}{lccc} 
res) & Nunca & Ocasionalmente & Frecuentemente \\
\hline Nunca & 48,5 & 29,1 & 18,0 \\
Ocasionalmente & 43,7 & 59,8 & 41,0 \\
Frecuentemente & 7,8 & 10,3 & 41,0 \\
\hline
\end{tabular}

Fonte: Elaboración propia

$\mathrm{O}$ nivel de ingresos do fogar das persoas enquisadas afecta claramente ao hábito de acudir a espectáculos entre menores de 16 anos. Hai que salientar que ningún menor que resida en fogares cuxos ingresos non superen os 1.000 euros vai a espectáculos con frecuencia. No outro extremo, os que máis acoden a este tipo de eventos son os que pertencen a fogares con retribucións superiores a 3.001 euros (un 24,49\% faino frecuentemente e un 57,14\% en ocasións), mentres que un $73,4 \%$ da rapazada que vive nos fogares con ingresos de entre $2.001 \mathrm{e}$ 3.000 euros ou ben van con frecuencia $(17,74 \%)$, ou ben ocasionalmente $(55,65 \%)$, tal e como se explica a continuación na gráfica.

Asistencia de menores de 16 anos a espectáculos por ingresos do fogar

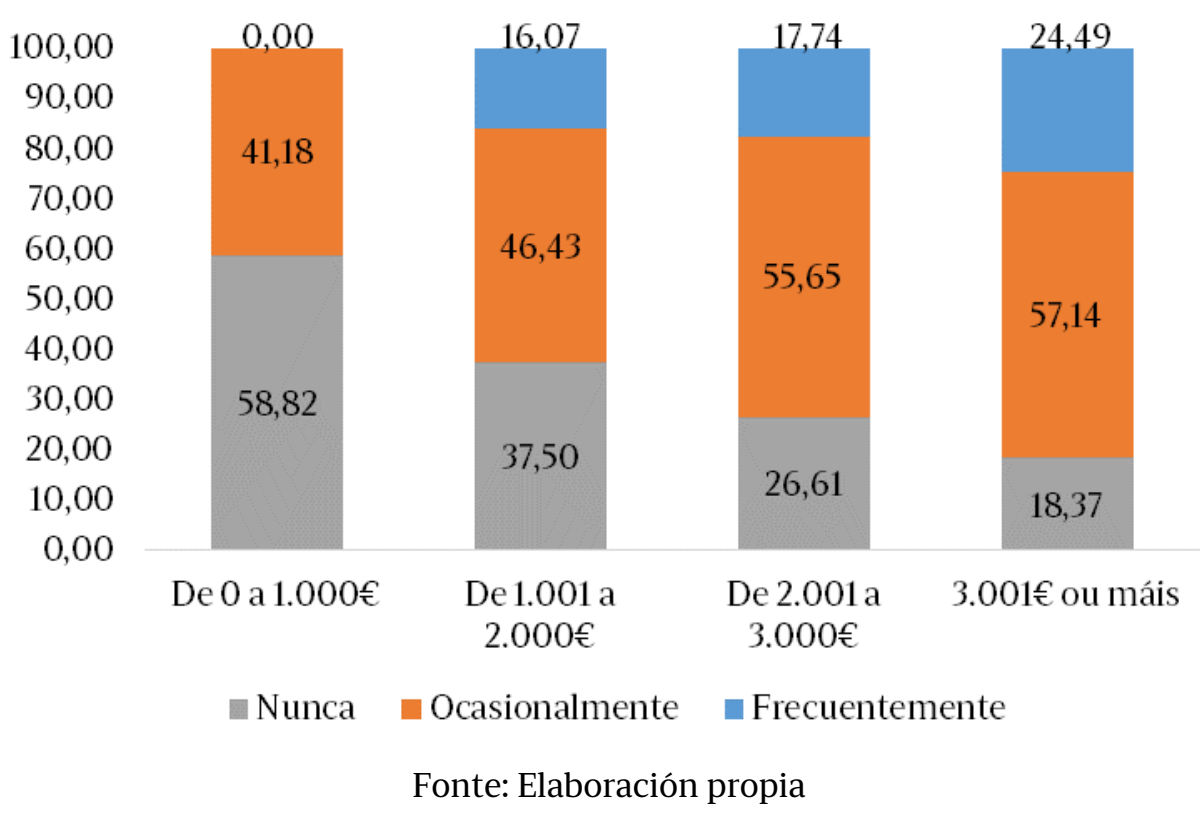

As persoas menores de 16 anos da provincia da Coruña $(74,5 \%)$, seguido das que residen na provincia de Pontevedra (64,4\%), son as que acoden en maior medida a espectáculos. Con todo, estas últimas fano con maior frecuencia que as primeiras (19,13\% fronte ao $16,34 \%)$. Ourense é a provincia en que menos acostuman ir a espectáculos, seguida por Lugo (57,8\% 62,3\%), como detalla a gráfica seguinte. 


\section{Asistencia de menores de 16 anos a espectáculos por provincia}

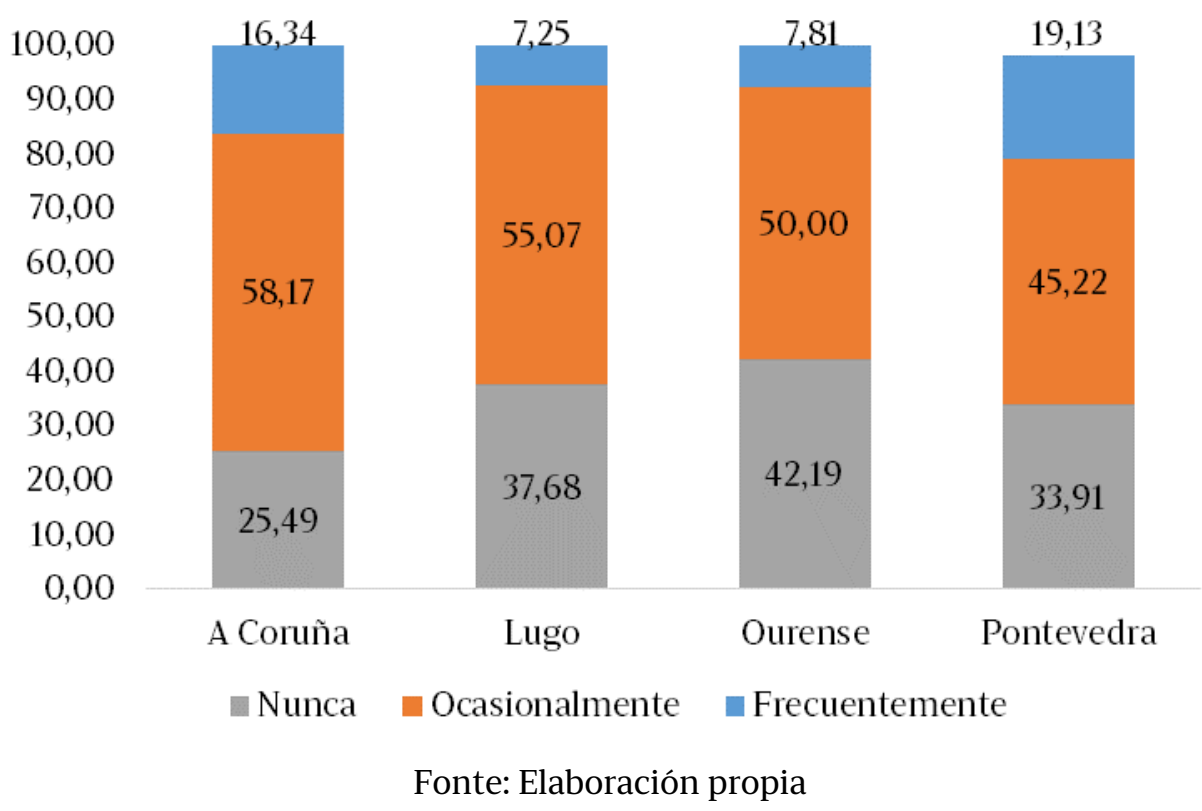

A afluencia de menores de 16 anos a espectáculos en lingua galega vese afectada por sete variables, cinco delas coincidentes coas que se abordaban no apartado anterior, concretamente: nivel de ingresos do fogar, lingua habitual de expresión, nivel de estudos, hábito de asistir ao teatro, circo ou contacontos e asistencia a concertos de música. Ademais, tamén inflúen as variables de ocupación da persoa entrevistada e o nivel de equipamento do seu fogar.

De novo, como se pode observar na gráfica, a influencia do nivel de estudos na asistencia da rapazada aos espectáculos en galego é evidente. Case o $68 \%$ dos que residen con adultos que posúen estudos primarios ou similares non vai nunca e só un 6,45\% o fai con frecuencia, o mesmo índice porcentual de quen posúe estudos secundarios, aínda que estes acoden máis de xeito ocasional. Aqueles menores que conviven con persoas de formación universitaria media ou superior asisten en moita máis medida (71,7\% e 61,2\%). 
Asistencia de menores de 16 anos a espectáculos en galego segundo o nivel de estudos das persoas enquisadas

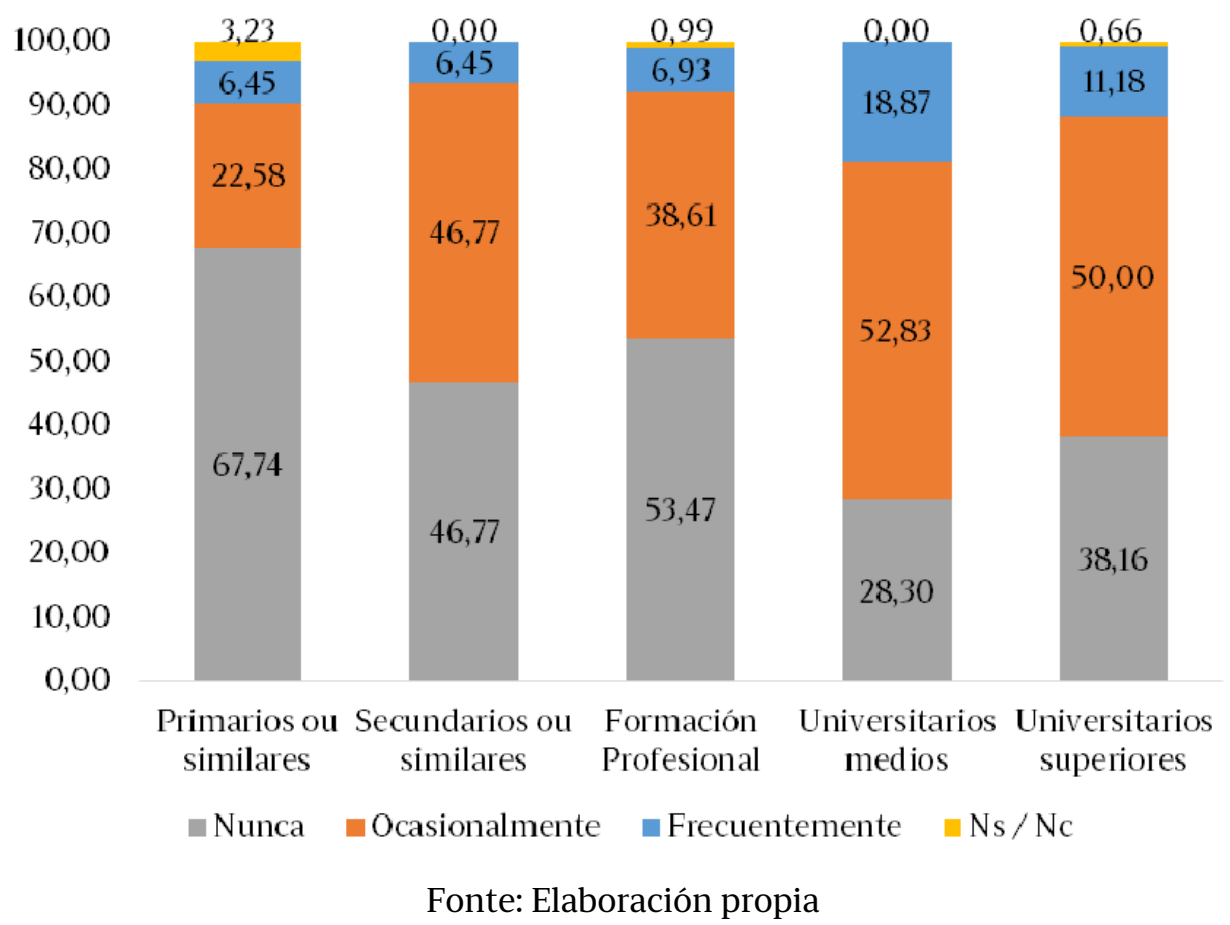

O nivel de equipamento do fogar da persoa coa que residen os menores de 16 anos afecta á súa práctica de asistir a espectáculos en lingua galega. Ningún acode con asiduidade a estes eventos cando o nivel é baixo, só un 17,65\% o fai ocasionalmente e un 76,47\% nunca (neste grupo hai unha elevada porcentaxe da opción "Non sabe, non contesta"). Porén, no caso dos fogares cun alto nivel de equipamento, a frecuencia entre menores acada o $11,7 \%$ e máis do $46 \%$ vai de xeito ocasional, índices equiparables aos dos fogares cun grao de equipamento medio, aínda que a frecuencia descende 2,1 puntos.

Asistencia de menores de 16 anos a espectáculos en galego segundo o nivel de equipamento do fogar

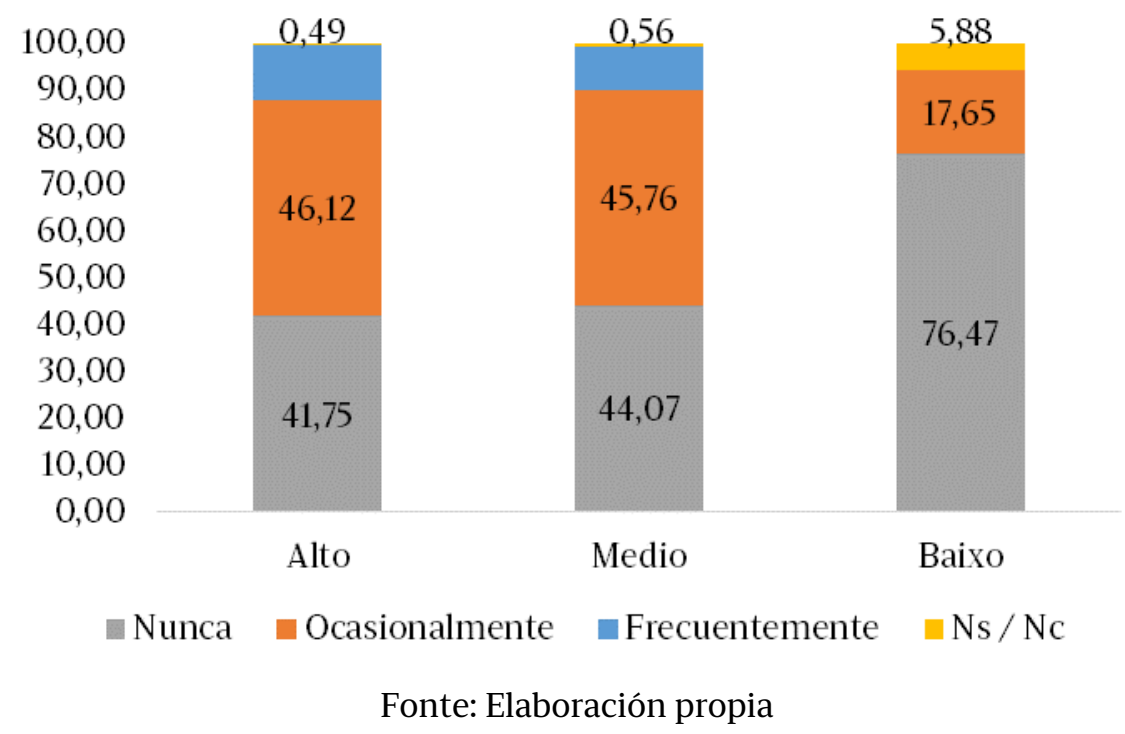


Case a metade de menores de 16 anos que residen con persoas asalariadas acoden ocasionalmente a espectáculos e un $9,75 \%$ fano frecuentemente. No caso dos autónomos a frecuencia da asistencia aumenta ata o 12,5\%, descende ata 0 20,83\% a porcentaxe de menores que adoitan ir en ocasións e acada o índice porcentual máis alto de menores que non van nunca, 64,6\%. É significativo que os nenos e nenas que conviven con estudantes non vaian nunca a este tipo de eventos, pero si son os que máis o fan de xeito ocasional, máis do 63\%.

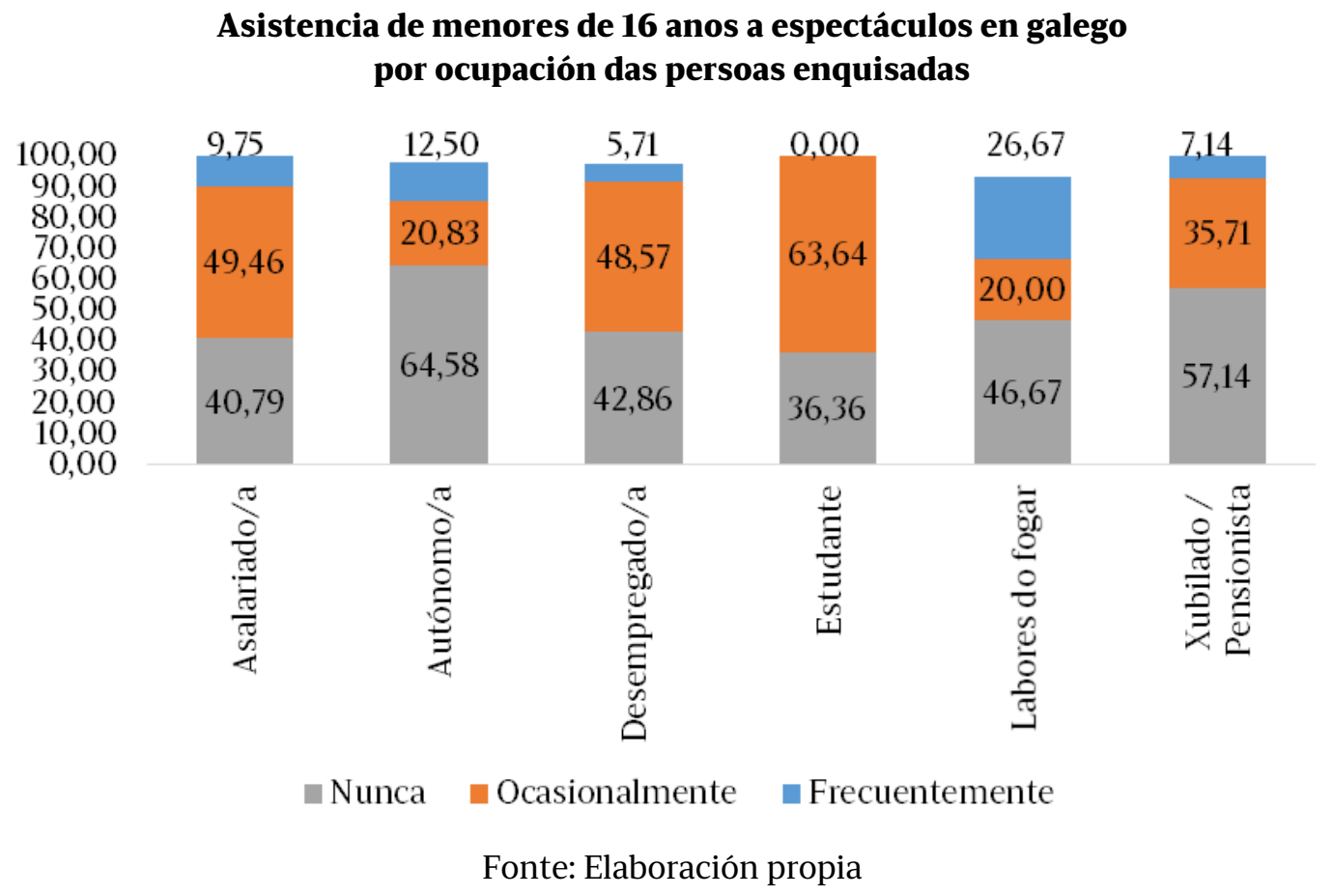

A táboa seguinte dá conta da vinculación entre a asistencia a espectáculos en galego de menores de 16 anos e a representacións de teatro, circo ou contacontos dos adultos cos que residen. Máis do $81 \%$ da cativada vai a espectáculos en galego cando as persoas coas que residen tamén o fan, para un 18,6\% é unha práctica frecuente e para un $42,4 \%$ ocasional. En cambio, se a persoa entrevistada declara que non vai nunca, o $62 \%$ da rapazada tampouco vai.

Asistencia de menores de 16 anos a espectáculos en galego segundo se as persoas enquisadas van ao teatro, circo ou contacontos

Vai a espectáculos en galego

Vai ao a teatro/circo/contacontos (persoas enquisadas)

\begin{tabular}{lccc} 
(menores) & Nunca & Ocasionalmente & Frecuentemente \\
\hline Nunca & 62,2 & 40,0 & 18,6 \\
Ocasionalmente & 32,6 & 53,2 & 42,4 \\
Frecuentemente & 5,2 & 5,4 & 39,0 \\
\hline
\end{tabular}

Fonte: Elaboración propia

A lingua tamén ten certa influencia na asistencia de menores a espectáculos en galego. Un $66,2 \%$ dos que conviven con persoas bilingües que falan máis galego que castelán vai con frecuencia $(6,76 \%)$ ou ocasionalmente $(59,46 \%)$, Os menores que viven con persoas que usan máis castelán que galego rexistran unhas porcentaxes de asistencia máis elevadas: un 14,97\% asiste a espectáculos 
frecuentemente e un 43,54\% en ocasións, tal como se pode observar a continuación na gráfica.

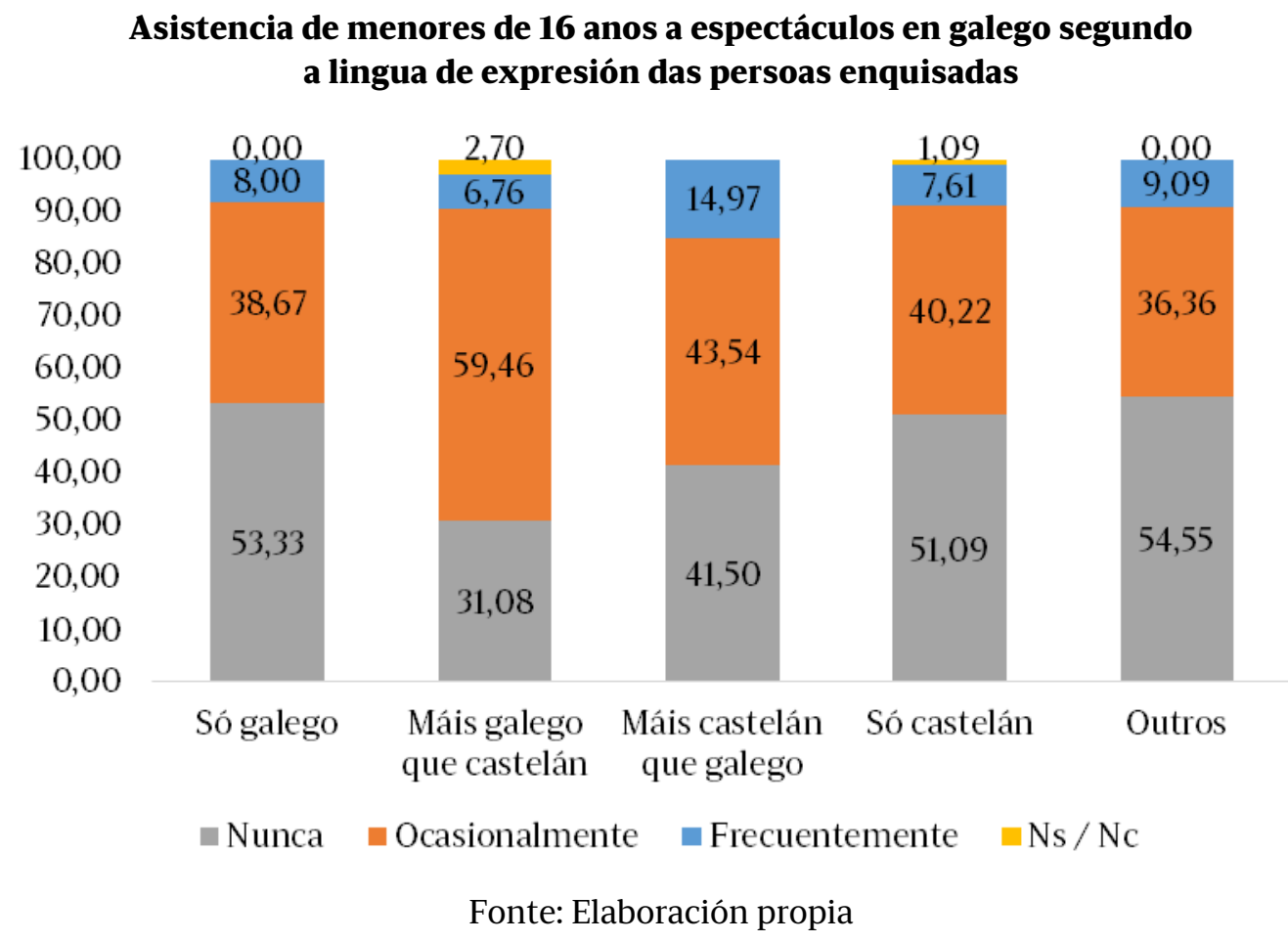

O hábito de asistir a concertos de música entre as persoas enquisadas inflúe significativamente na asistencia de menores a espectáculos en lingua galega. De feito, case o $28 \%$ da rapazada que reside con persoas que van frecuentemente tamén ten o mesmo hábito. Isto implica que a taxa de asistencia rexistra 19,3 puntos porcentuais por riba de quen convive coas persoas que van ocasionalmente e 24 sobre nenos e nenas que viven con adultos que non van nunca. Ademais, dentro este último grupo, un $60 \%$ dos menores non vai nunca a espectáculos en galego.

\section{Asistencia de menores de 16 anos a espectáculos en galego segundo se as persoas enquisadas van a concertos de música}

\begin{tabular}{|c|c|c|c|}
\hline \multirow[b]{2}{*}{$\begin{array}{l}\text { Vai a espectáculos en galego (meno- } \\
\text { res) }\end{array}$} & \multicolumn{3}{|c|}{ Vai a concertos de música (persoas enquisadas) } \\
\hline & Nunca & Ocasionalmente & Frecuentemente \\
\hline Nunca & 60,2 & 40,6 & 31,2 \\
\hline Ocasionalmente & 35,9 & 50,0 & 39,3 \\
\hline Frecuentemente & 3,9 & 8,6 & 27,9 \\
\hline
\end{tabular}

Fonte: Elaboración propia

De xeito semellante ao sucedido con outras variables analizadas, o nivel de ingresos do fogar das persoas enquisadas inflúe no hábito dos menores de 16 anos que conviven con elas xa que, canto maiores son os ingresos, máis frecuente é a actividade cultural dos rapaces. Neste caso, nos fogares cuxos ingresos son superiores a 3.001 euros, un 20,4\% da rapazada acode a espectáculos de música en galego frecuentemente, cunha diferenza sobre os de ingresos de entre $2.001 \mathrm{e}$ 3.000 e de 1.001 a 2.000 euros de más de 10 puntos porcentuais. Esta variación aumenta en 14,5 puntos ao comparalos coas vivendas con rendas por debaixo 
dos 1.000 euros, grupo en que case o $65 \%$ de menores de 16 anos non vai nunca a este tipo de eventos.

Asistencia de menores de 16 anos a espectáculos en galego por nivel de ingresos do fogar

100,00
90,00
80,00
70,00
60,00
50,00
40,00
30,00
20,00
10,00
0,00

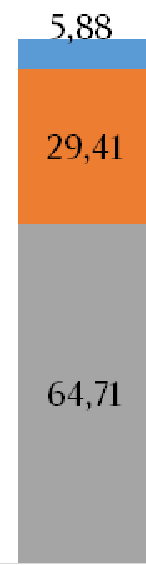

9,82

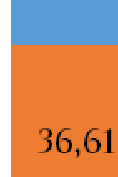

9,68

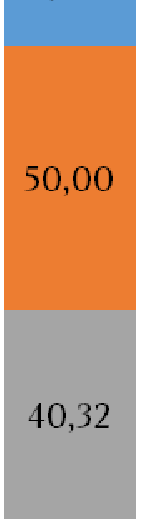

20,41

90,00

,

60,00

50,00

40,00

30,00

20,00

0,00

De 0 a $1.000 €$

De 1.001 a

De 2.001 a $2.000 €$

$3.000 €$

nunca @ Ocasionalmente $\quad$ Frecuentemente

Fonte: Elaboración propia

\subsection{CINE EN SALA}

O dato máis salientable deste apartado é a elevada porcentaxe de menores de 16 anos que non asisten nunca ao cine en galego (91,5\%) e que só un 7,5\% vai nalgunha ocasión. Pola contra, o 69,6\% si que vai ás salas de cine, ou ben de xeito ocasional ou frecuente, como se mostra na gráfica.

\section{Consumo de cine e cine en galego entre menores de 16 anos}

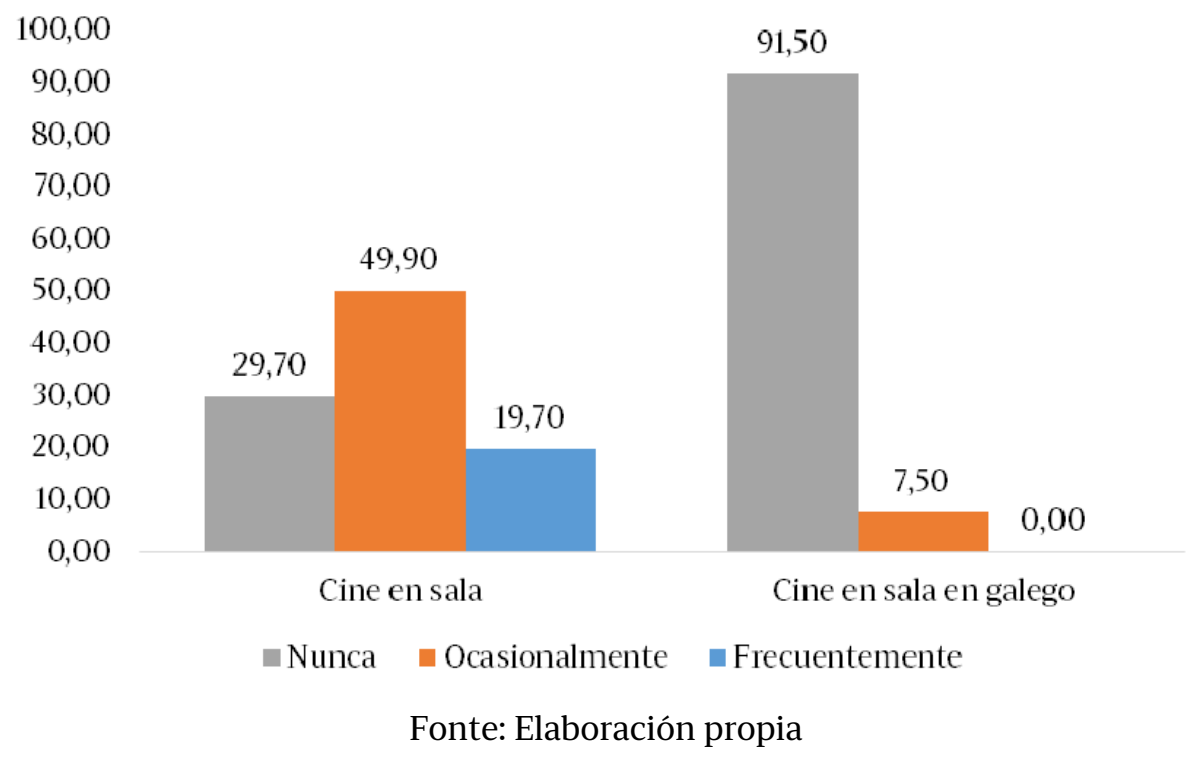


Unha vez extraídos os resultados, aparecen dúas variables que afectan en maior medida ao consumo de cine en sala: a subscrición das persoas enquisadas a algunha plataforma dixital de contidos culturais e a asistencia destas ao cine.

Verifícase que o consumo de cine en sala entre menores de 16 anos aumenta cando a persoa entrevistada declara que está subscrita a algunha plataforma de contido cultural, cunha diferenza porcentual de case 8 puntos con respecto ás persoas que non dispoñen de ningunha subscrición ( 21,45\% e 13,68\% respectivamente). Neste último caso, ademais, a cota de menores de 16 anos que non van nunca ao cine acada o 42,11\%, fronte ao $25,74 \%$ dos que residen en fogares subscritos a plataformas dixitais.

\section{Consumo de cine en sala entre menores de 16 anos segundo a subscrición a algunha plataforma dixital de contido cultural}

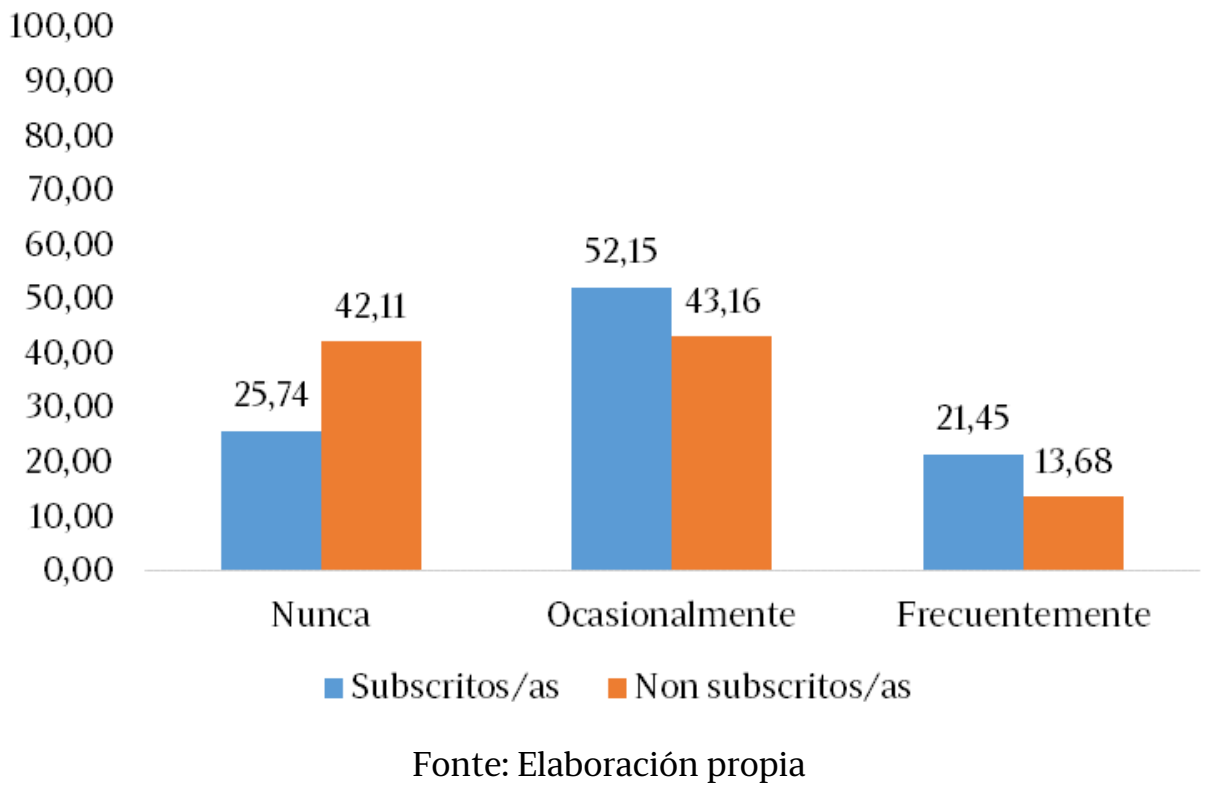

Constátase de novo que os patróns de conduta dos adultos son clave nas prácticas culturais dos menores. Nesta ocasión, confírmase que un 54,4\% dos rapaces e rapazas que frecuentan o cine conviven con persoas que tamén o fan. Se se suman estes aos que van ocasionalmente, acadan case o 89\% de asistentes. A medida que se reduce ese hábito en adultos, tamén diminúe na mocidade. De feito, case o $60 \%$ dos menores que non van nunca residen coas persoas que tampouco o fan.

\section{Consumo de cine en sala entre os menores de 16 anos segundo se as persoas enquisadas van ao cine}

Vai ao cine (persoas enquisadas)

\begin{tabular}{lccc} 
Consumo cine en sala (menores) & Nunca & Ocasionalmente & Frecuentemente \\
\hline Nunca & 59,4 & 21,4 & 11,4 \\
Ocasionalmente & 30,2 & 65,6 & 34,2 \\
Frecuentemente & 8,5 & 12,6 & 54,4 \\
\hline
\end{tabular}

Fonte: Elaboración propia 
Como se mencionaba ao principio deste apartado, a asistencia ao cine en galego é moi baixa entre menores de 16 anos, xa que tan só un 7,5\% vai nalgunha ocasión. As variables que afectan de xeito máis significativo son o hábitat en que residen as persoas entrevistadas e a propia asistencia destas ao cine en lingua galega.

Tal e como mostra a seguinte gráfica, constátase que os menores que acoden ao cine en galego con máis frecuencia son os que residen en vilas de tamaño medio, cunha poboación de entre 20.000 e 50.000 habitantes (22,22\%), seguidos polos que viven en vilas de menos de 5.000 habitantes $(20,31 \%)$ e nas grandes cidades (19,9\%). Con todo, compróbase que o maior índice de asistencia lle corresponde a menores que residen nas cidades, xa que un $75,5 \%$ vai o cine ou ben frecuentemente ou de xeito ocasional, mentres que os que viven en vilas pequenas (entre 10.000 e 20.000 habitantes) son os que menos van. Destacan de xeito moi significativo os menores que viven en núcleos de poboación pequenos, onde un $71,9 \%$ acode ao cine en galego frecuente ou ocasionalmente, tal e como se mostra a continuación na gráfica.

\section{Consumo de cine en sala galego entre menores de 16 anos por hábitat}

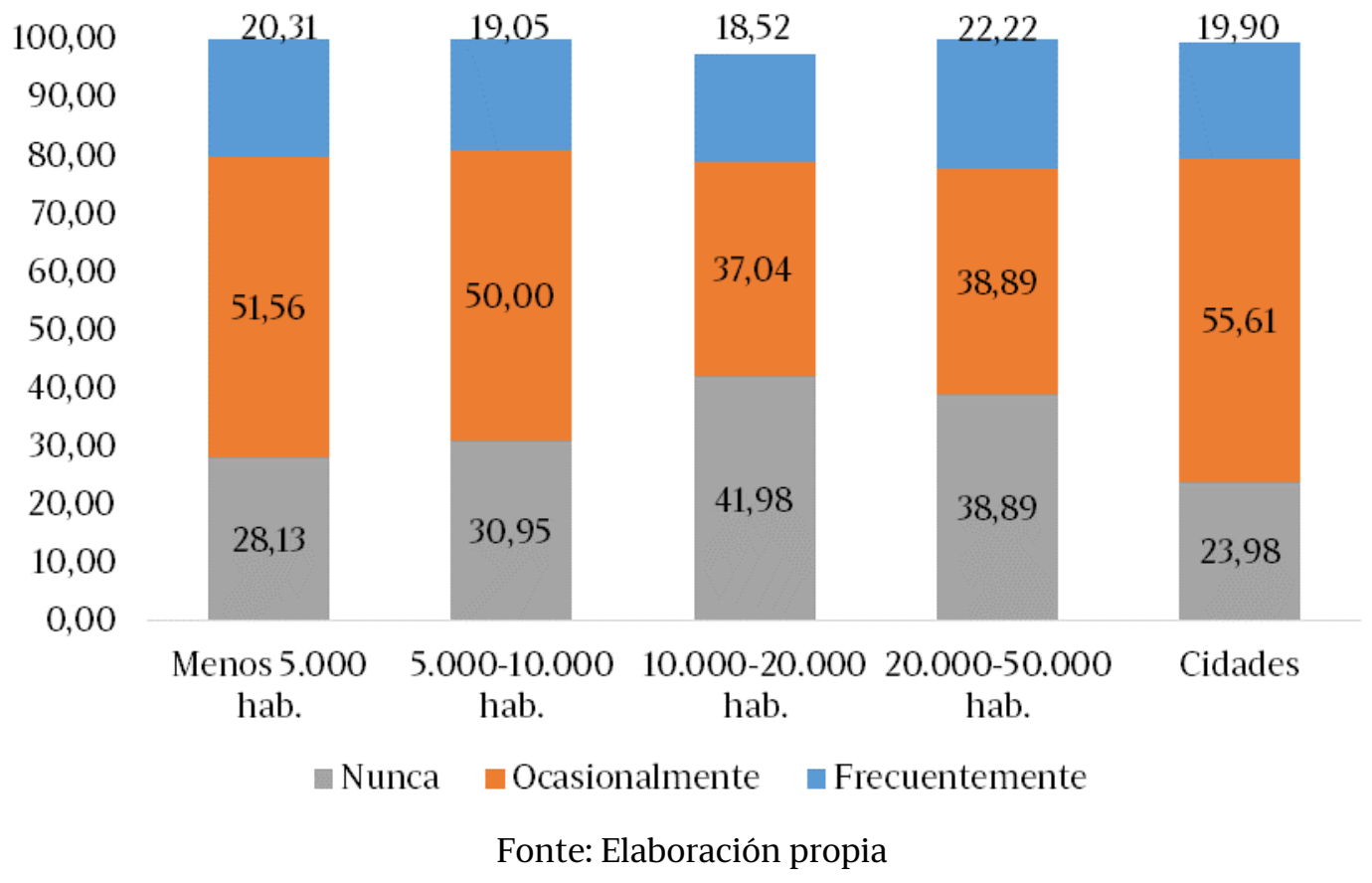

O consumo de cine en sala en lingua galega entre menores de 16 anos experimenta o mesmo comportamento que o consumo noutros idiomas, é dicir, canto máis van os adultos entrevistados, máis van os nenos e nenas que residen con eles. Un 54,4\% dos que van con frecuencia correspóndese cos que viven con persoas que tamén consomen cine en galego frecuentemente. No caso oposto, case un $60 \%$ dos que non asisten nunca ao cine reside con adultos que tampouco o fan. 


\section{Consumo de cine en sala en galego entre menores de 16 anos segundo se as persoas enquisadas van ao cine}

Vai ao cine (persoas enquisadas)

\begin{tabular}{lccc} 
Consumo cine en sala en galego (menores) & Nunca & Ocasionalmente & Frecuentemente \\
\hline Nunca & 59,4 & 21,4 & 11,4 \\
Ocasionalmente & 30,2 & 65,6 & 34,2 \\
Frecuentemente & 8,5 & 12,6 & 54,4 \\
\hline
\end{tabular}

Fonte: Elaboración propia

\subsection{MUSEOS E EXPOSICIÓNS}

Un 35,2\% dos menores de 16 anos non acostuma visitar museos ou exposicións nunca, porcentaxe que aumenta ata o 51,9\% cando esta actividade se presenta en lingua galega. Esta variación relacionada co idioma tamén se manifesta cando se trata de visitas ocasionais ou frecuentes, con diferenzas de 12 e 5,2 puntos respectivamente, tal e como se constata na seguinte gráfica.

Visitas a museos e museos en galego entre os menores de 16 anos do fogar

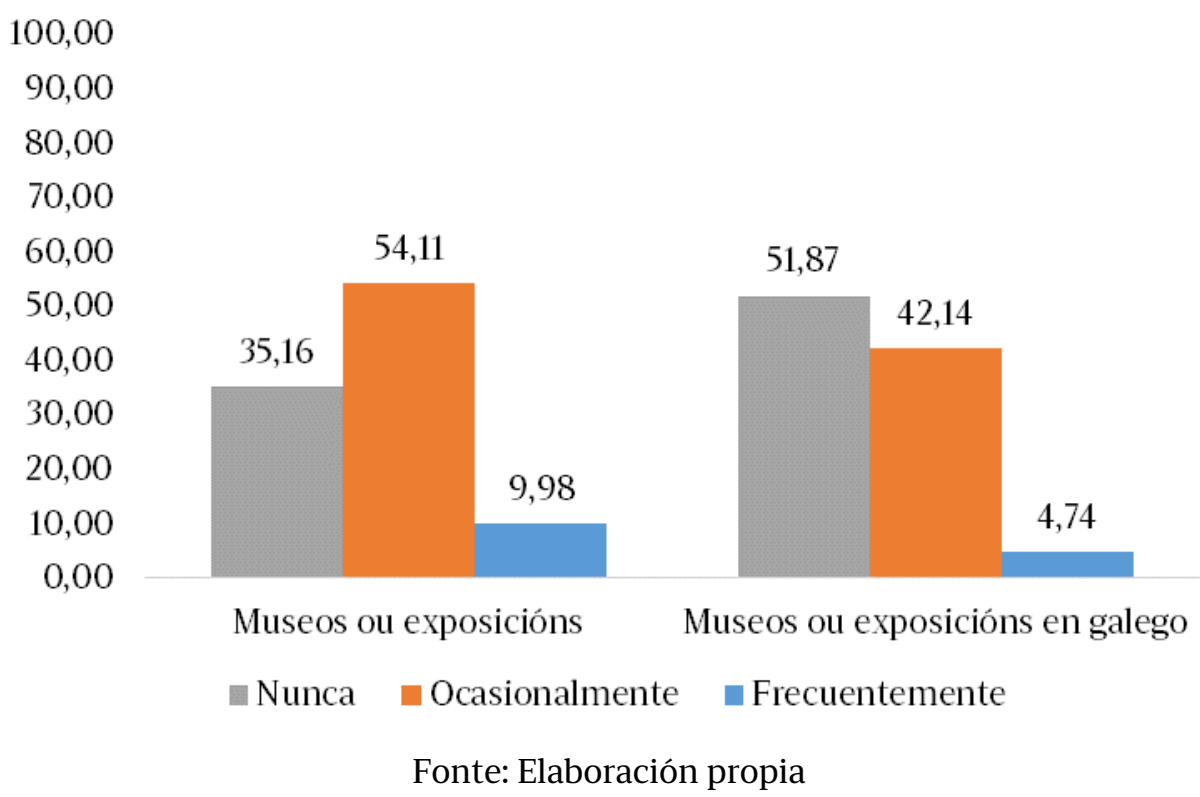

Ao estudar a asistencia de menores de 16 anos a museos e exposicións, atopáronse oito variables con influencia significativa na práctica desta actividade cultural: a subscrición por parte das persoas enquisadas a algunha plataforma de contido cultural, a ocupación, os ingresos do fogar, o nivel de equipamento do fogar, a lingua en que aprenderon a falar os fillos/as, o hábito de visitar museos e monumentos e o nivel de estudos da persoa entrevistada.

Como vén sendo habitual ao longo deste informe, canto maior é o nivel de estudos da persoa entrevistada, as probabilidades de que os menores que residan nese fogar vaian aos museos aumenta. A maior cota porcentual de menores que visitan museos de xeito frecuente ou ocasional pertence aos que conviven con persoas que posúen estudos universitarios medios (81\%) ou superiores 
(73\%). En cambio, entre os menores que residen con persoas que declararon que teñen estudos primarios ou similares, ningún vai con frecuencia e un 32,3\% achégase aos museos ou exposicións ocasionalmente. Na seguinte gráfica amósanse os resultados polo miúdo.

Visitas a museos/exposicións de menores de 16 anos segundo o nivel de estudos

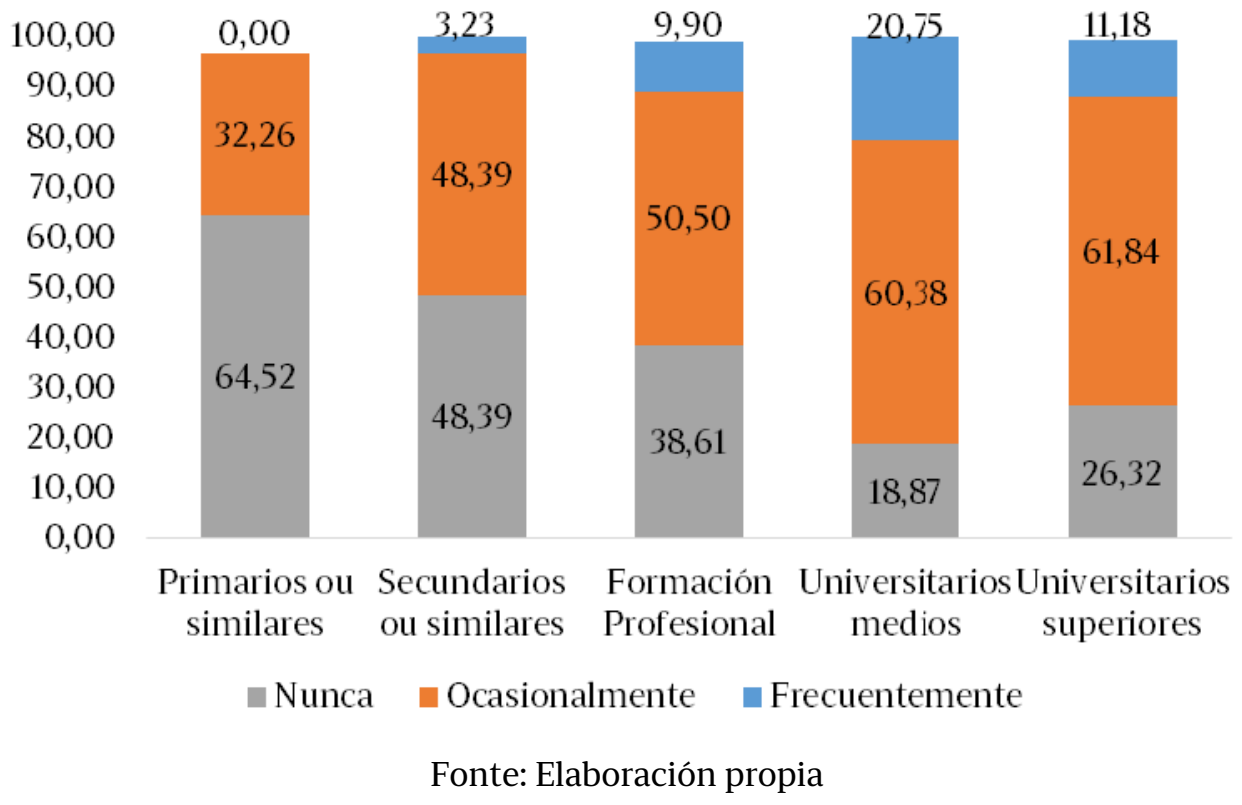

Unha das variables que aparece reiteradamente neste traballo e que exerce unha grande influencia no comportamento dos menores de 16 anos é a propia conduta dos adultos cos que residen. Neste caso, canto maior é a frecuencia coa que as persoas enquisadas asisten aos museos e monumentos, aumenta tamén a frecuencia coa que van os rapaces e rapazas. Como se pode comprobar na táboa que vai a continuación, case o 91\% dos menores que conviven con adultos que visitan museos frecuentemente vai a museos e exposicións ou ben con frecuencia $(43,6 \%)$ ou ben ocasionalmente $(47,3 \%)$. No extremo oposto atópanse os menores que viven en fogares onde non se ten o hábito de ir a museos e exposicións: un 73,9\% non visita xamais museos e non chega ao 1\% quen vai con frecuencia.

\begin{tabular}{|c|c|c|c|}
\hline \multirow[b]{2}{*}{$\begin{array}{l}\text { Visita muse- } \\
\text { os/exposicións } \\
\text { (menores) }\end{array}$} & \multicolumn{3}{|c|}{ Visita museos/monumentos (persoas enquisadas) } \\
\hline & Nunca & Ocasionalmente & Frecuentemente \\
\hline Nunca & 73,9 & 22,7 & 9,1 \\
\hline Ocasionalmente & 25,2 & 69,7 & 47,3 \\
\hline Frecuentemente & 0,9 & 6,4 & 43,6 \\
\hline
\end{tabular}

Fonte: Elaboración propia 
A frecuencia das visitas de menores de 16 anos a museos e exposicións é máis baixa se o idioma en que aprenderon a falar os fillos/as das persoas entrevistadas foi o galego, concretamente un 5,08\%. Aumenta ao 9,14\% no caso de ser o castelán, ao 11,94\% cando aprenderon nas dúas linguas e ao 13,33\% se a aprendizaxe foi noutras linguas. Con todo, a maior cota de asistencia dáse nos menores que aprenderon só en castelán, cunha porcentaxe total de rapaces e rapazas que van de xeito frecuente e ocasional de case un 78\%, como se pode comprobar na seguinte gráfica.

\section{Visitas a museos/exposicións de menores de 16 anos segundo a lingua en que aprenderon a falar os fillos/as das persoas entrevistadas}

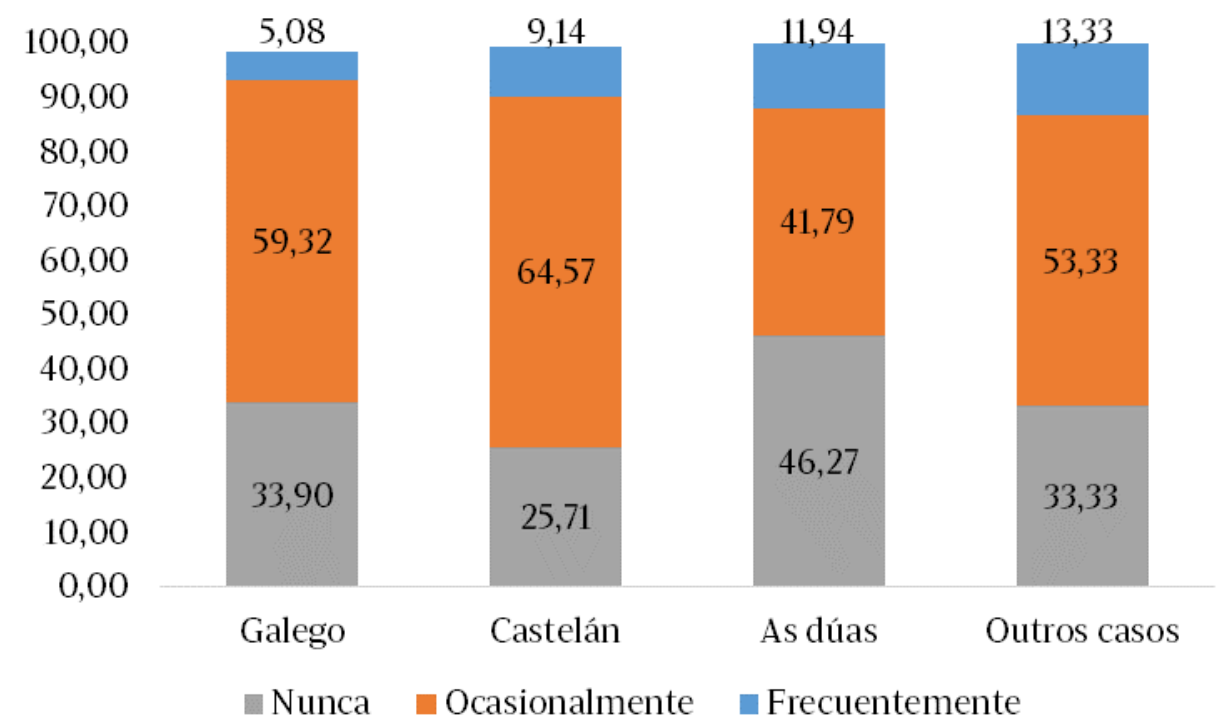

Fonte: Elaboración propia

O nivel de equipamento dos fogares é outra variable que incide de forma significativa neste indicador. Máis do $70 \%$ dos menores de 16 anos que contan cun alto nivel de equipamento no fogar acoden a museos e exposicións, ou ben con frecuencia $(13,11 \%)$ ou ben ocasionalmente $(57,28 \%)$, índice que baixa ata $o$ $60 \%$ para quen dispón dun nivel medio de equipamento, cunha cota de asistencia frecuente de 5,8 puntos porcentuais por debaixo dos anteriores. Case o 59\% dos nenos e nenas que residen en fogares cun baixo nivel de equipamento non se achegan nunca a estes espazos culturais e ningún o fai con frecuencia. 


\section{Visitas a museos/exposicións dos menores de 16 anos segundo o nivel de equipamento do fogar das persoas enquisadas}

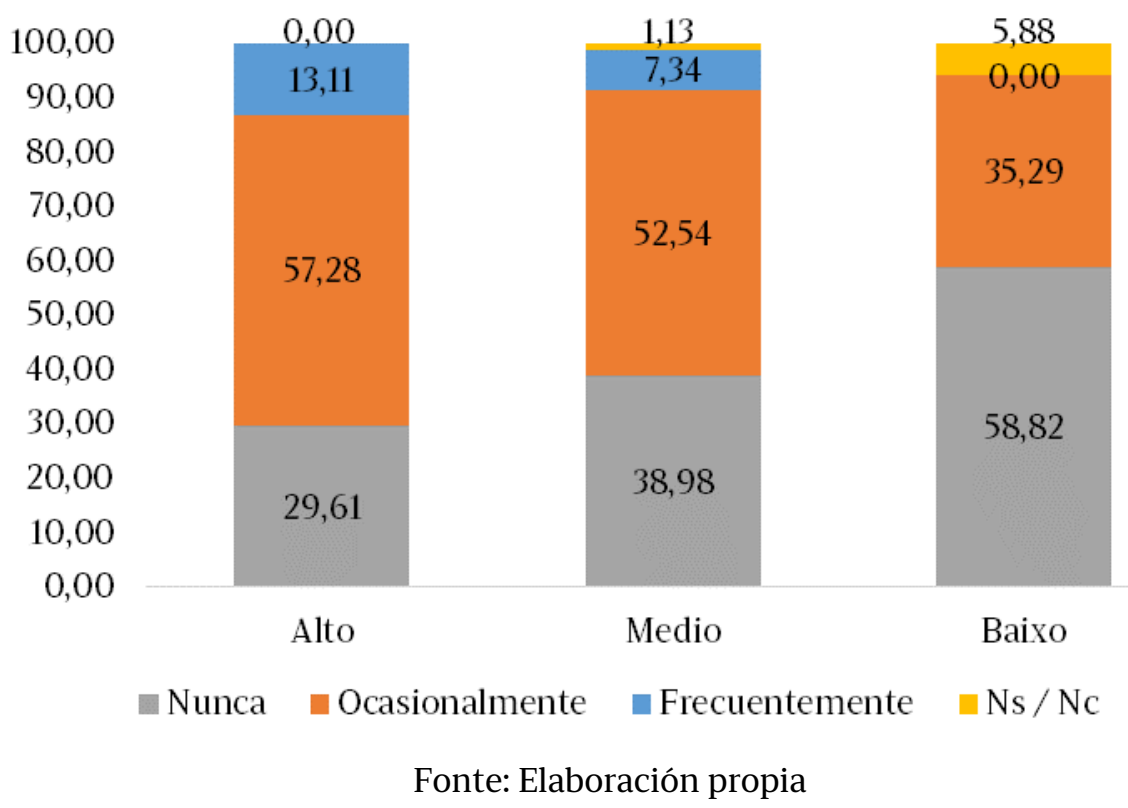

Como vén sucedendo en apartados anteriores, os resultados demostran que os ingresos dos fogares das persoas enquisadas afectan, en xeral, á realización de actividades culturais de menores de 16 anos. 0 76,6\% dos que residen en fogares con ingresos de entre 2.001 a 3.000 euros visita exposicións e museos, un 14,52\% deles faino con frecuencia; tamén un $71,4 \%$ dos que viven en fogares con ingresos de máis de 3.001 euros, cun 12,2\% deles que se achegan frecuentemente. Pola contra, case o $53 \%$ dos que pertencen a fogares con menos de 1.000 euros de renda non acoden nunca a estes espazos. A gráfica que vai a continuación reflicte estes resultados.

Visitas a museos/exposicións de menores de 16 anos por ingresos do fogar

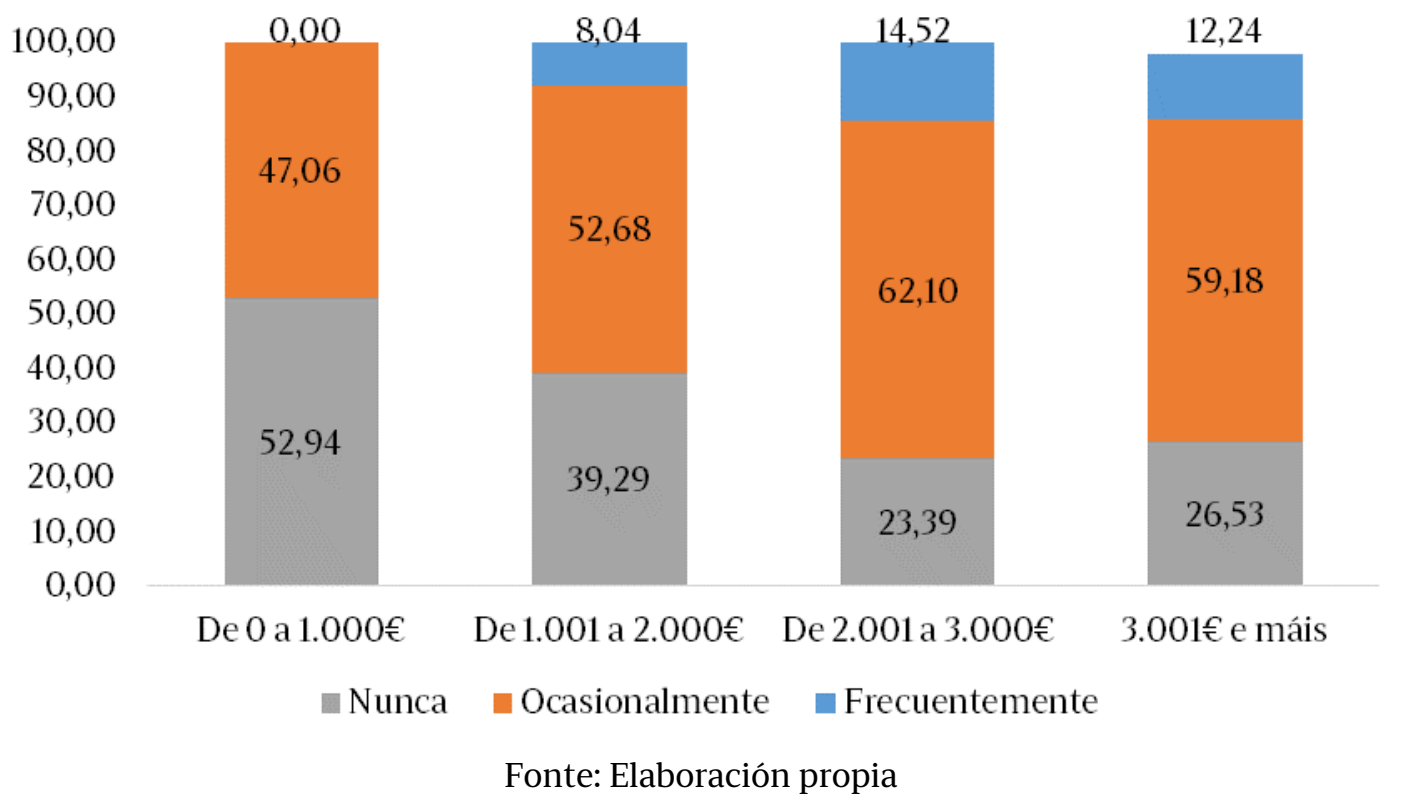


Na análise por provincias, A Coruña e Pontevedra son as que contan cunha porcentaxe maior de menores que van a museos e exposicións, en comparación con Lugo e Ourense. Con todo, un 11,6\% dos rapaces e rapazas da provincia de Lugo achégase con frecuencia (lixeiramente por riba dos da Coruña), cota que diminúe ata o 3,1\% no caso dos da provincia de Ourense.

Visitas a museos/exposicións de menores de 16 anos por provincia

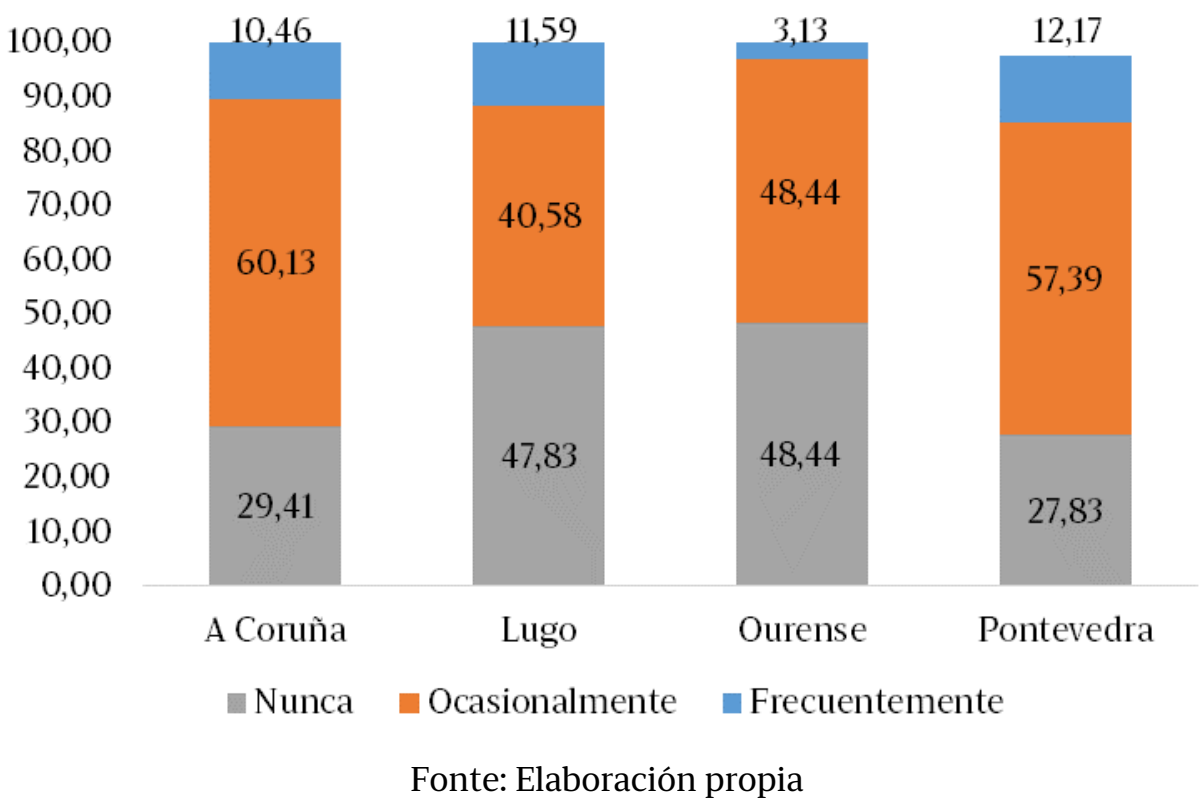

O 70\% de menores de 16 que residen con persoas asalariadas adoita visitar museos e exposicións (un 10,11\% faino con frecuencia e case un $60 \%$ de xeito ocasional), seguidos polos que conviven con autónomos (11,43\%). A maior porcentaxe de menores que visitan estes espazos culturais con frecuencia é a dos que viven con estudantes (18,18\%). A cota porcentual máis alta de quen non vai nunca correspóndelles aos nenos e nenas dos fogares en que as persoas entrevistadas realizan labores do fogar, un $66,7 \%$, tal como se mostra na seguinte gráfica. 
Visita a museos/exposicións de menores de 16 anos segundo a ocupación das persoas enquisadas

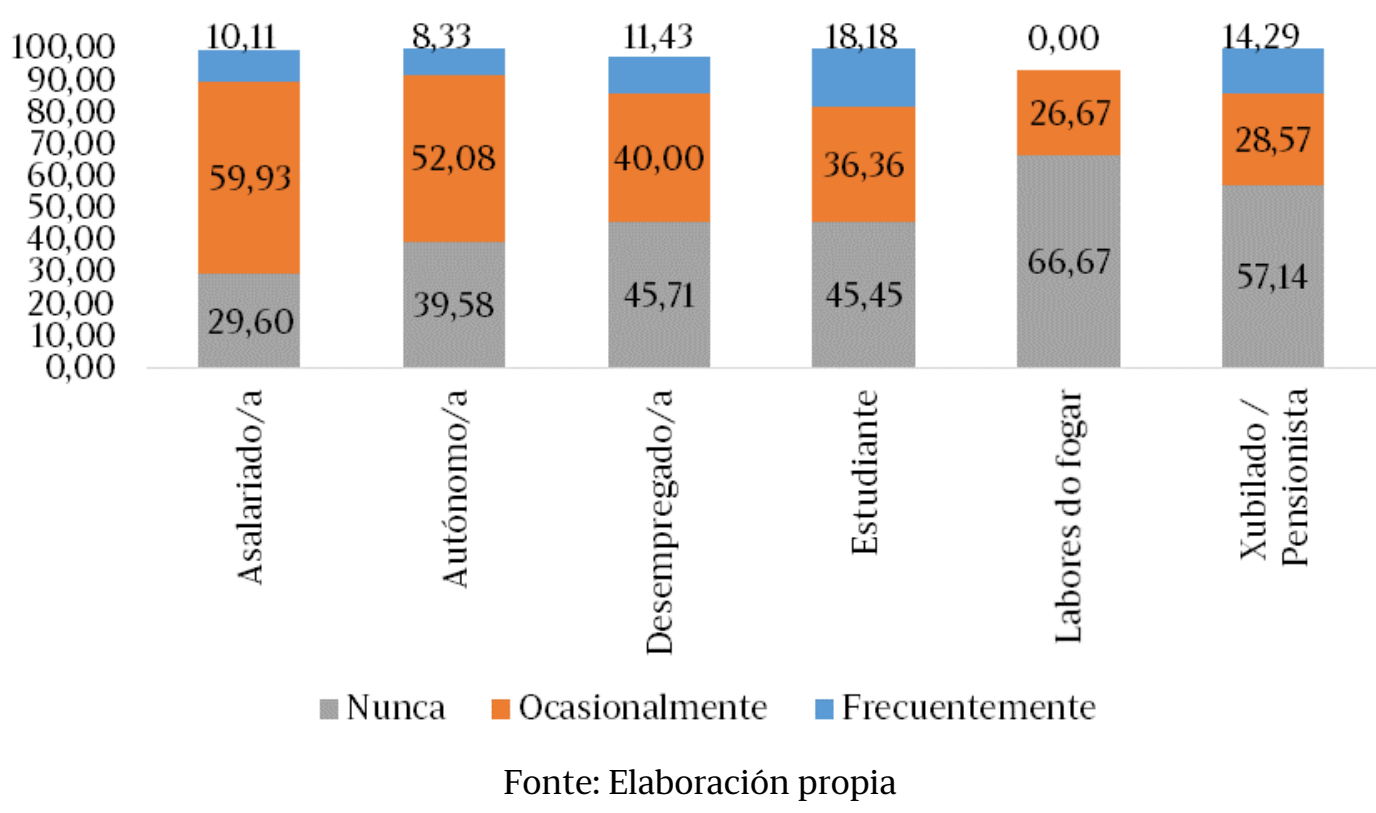

A posible subscrición a algunha plataforma dixital de contido cultural por parte das persoas enquisadas tamén repercute no hábito de visitar museos ou exposicións entre menores de 16 anos. Un $68,7 \%$ das persoas que contan cunha subscrición deste tipo adoita ir, 18 puntos por riba das que non dispoñen deste servizo, como se constata na gráfica que vai a continuación.

Visita a museos/exposicións de menores de 16 anos segundo se as persoas enquisadas están subscritas a algunha plataforma dixital de contido cultural

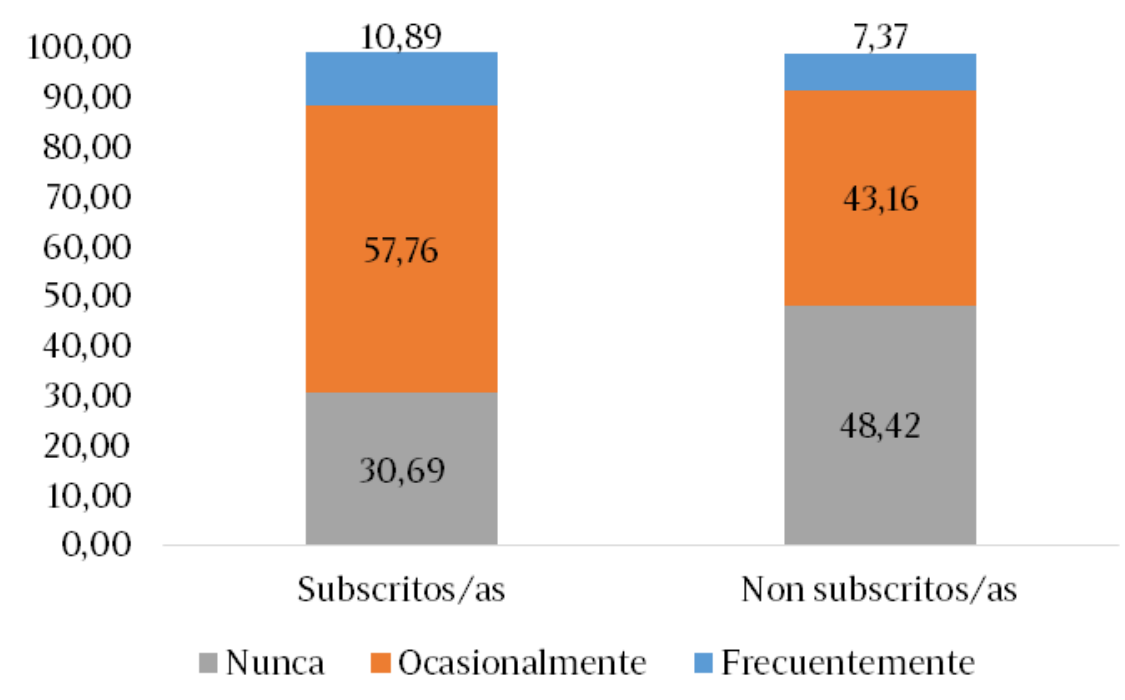

Fonte: Elaboración propia

Da análise das visitas a museos e exposicións en lingua galega de menores de 16 anos, obtéñense tres variables que inciden nesta práctica cultural da rapazada: a subscrición das persoas enquisadas a algunha plataforma dixital de contido cultural, o nivel de formación, a lingua en que aprenderon a falar os seus fillos e fillas e a frecuencia das súas visitas a museos ou monumentos. 
Como se vén constatando dende o principio deste capítulo, o nivel de estudos é unha variable influente. O 60,4\% e o 50,7\% dos menores que conviven con persoas con estudos universitarios medios e superiores respectivamente acostuman visitar museos e exposicións, mentres que só un 22,6\% dos que residen con adultos que contan con estudos primarios e un 37,1\% con secundarios o fan nalgunha ocasión.

Visita a museos/exposicións en galego de menores de 16 anos por nivel de estudos

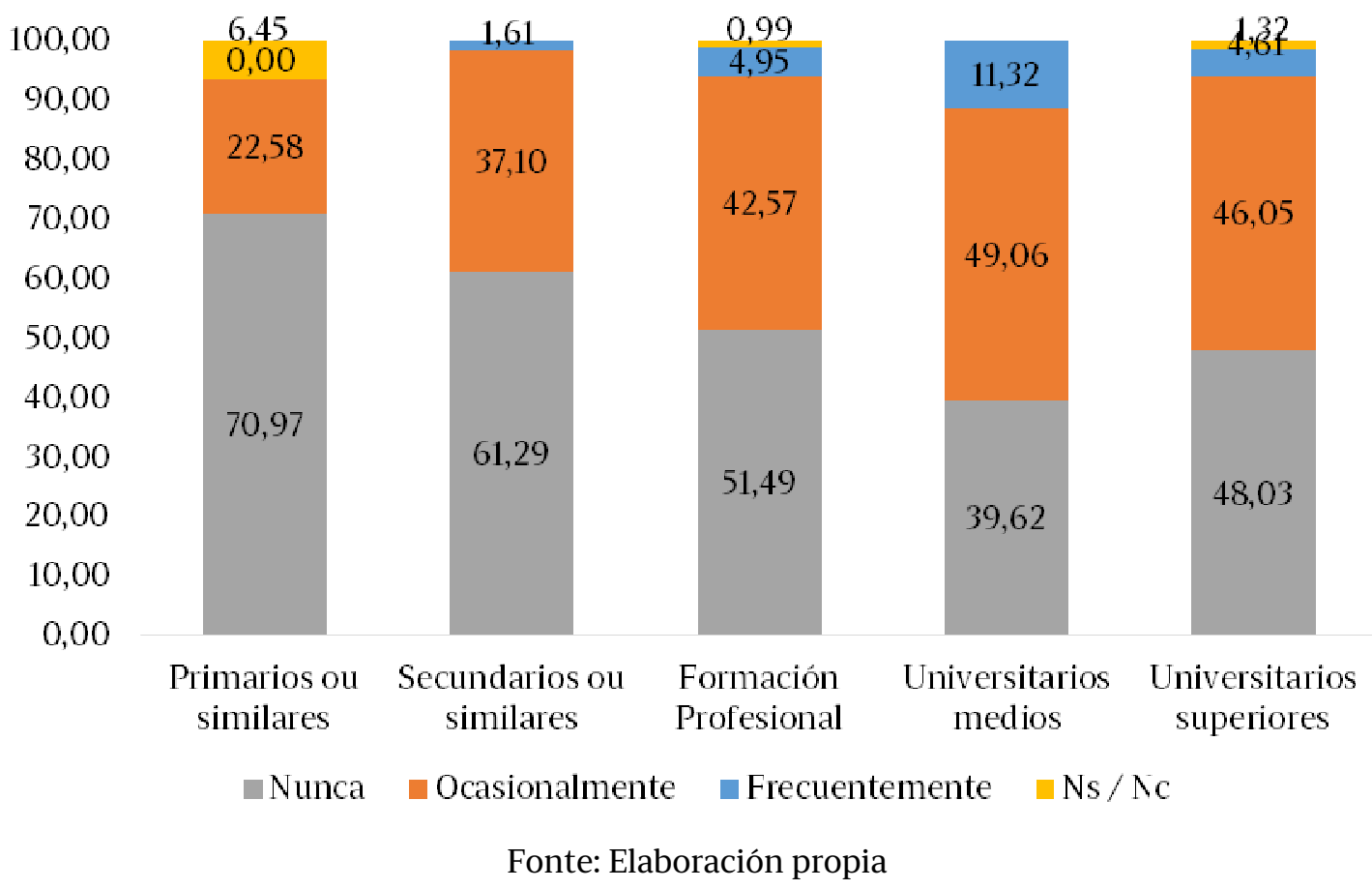

De novo, a subscrición da persoa entrevistada a plataformas dixitais de contido cultural repercute na visita dos menores a museos e exposicións. Máis da metade dos rapaces e rapazas que viven en fogares con este tipo de servizo asisten a museos e exposicións, 13,6 puntos porcentuais por riba dos que non dispoñen de ningunha plataforma. Con todo, cabe sinalar que neste último grupo é maior a porcentaxe dos que van frecuentemente (7,4\% fronte ao $4 \%$ ). 
Visita a museos/exposicións en galego dos menores de 16 anos segundo se as persoas enquisadas están subscritas a algunha plataforma dixital de contido cultural

100,00
90,00
80,00
70,00
60,00
50,00
40,00
30,00
20,00
10,00
0,00

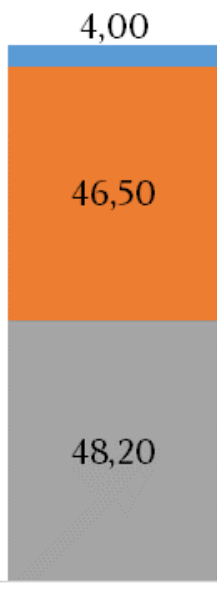

Subscritos/as
7,40

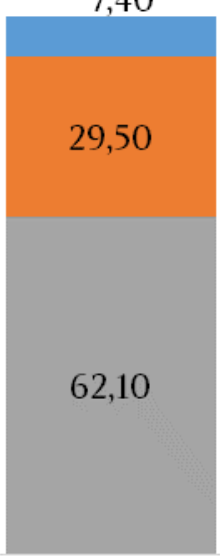

Non subscritos/as

- Nunca Ocasionalmente Frecuentemente

Fonte: Elaboración propia

Un 54,3\% de quen aprendeu a falar en castelán visita museos e exposicións con contidos en galego, seguidos por quen aprendeu en galego, case un 51\%. Cómpre tamén apuntar que o índice de nenos e nenas que non van nunca é moi elevado entre os que aprenderon nas dúas linguas ou noutros idiomas, por riba do $60 \%$.

\section{Visita a museos/exposicións en galego de menores de 16 anos segundo a lingua en que aprenderon a falar os fillos/as das persoas enquisadas}

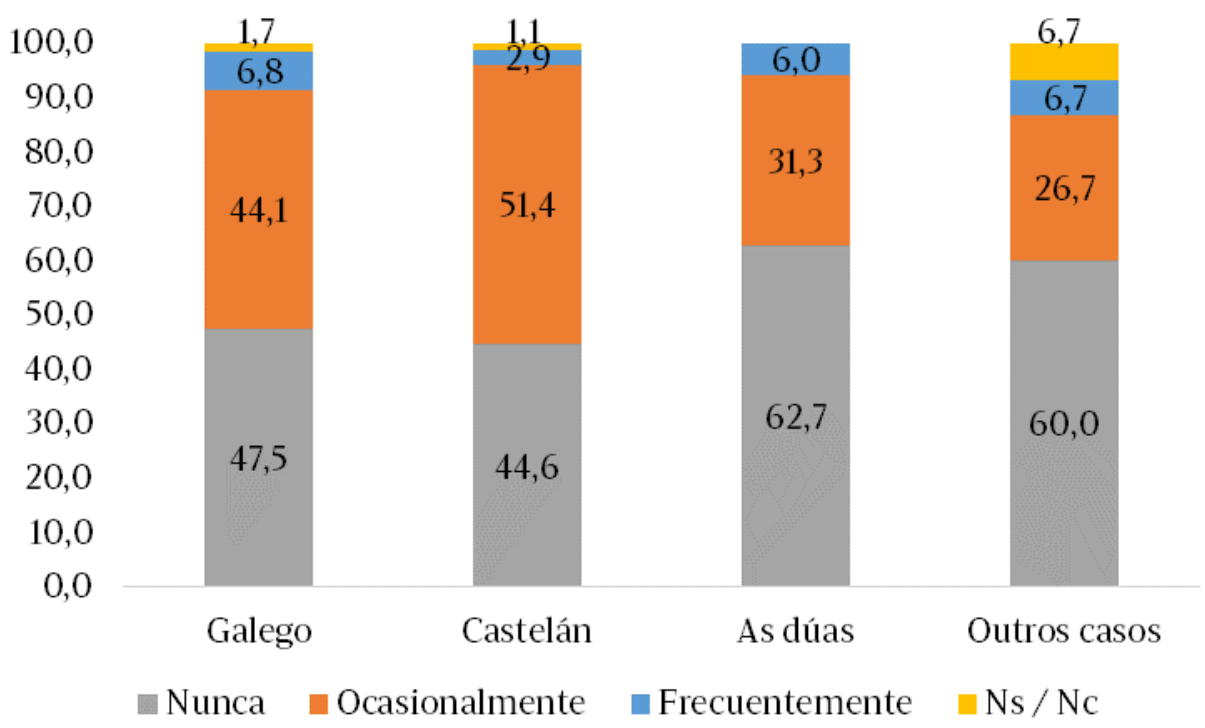

Fonte: Elaboración propia

Case un 73\% dos menores visitan museos e exposicións se os adultos cos que residen visitan estes espazos con frecuencia e un 54,3\% se o fan ocasionalmente, se ben é certo que neste último caso a frecuencia é moito máis baixa que no anterior, 19,3 puntos porcentuais menos. Só un 18\% dos menores que viven con 
adultos que non acoden nunca a un museo fano nalgunha ocasión, mentres que máis do $80 \%$ non vai nunca.

Visitas a museos/exposicións en galego dos menores de 16 anos segundo se as persoas enquisadas tamén os visitan

\begin{tabular}{lccc} 
& \multicolumn{3}{c}{ Visitan museos/monumentos (persoas enquisadas) } \\
Visitan museos (menores) & Nunca & Ocasionalmente & Frecuentemente \\
\hline Nunca & 80,2 & 44,0 & 27,3 \\
Ocasionalmente & 18,0 & 51,7 & 50,9 \\
Frecuentemente & 0,9 & 2,6 & 21,8 \\
\hline
\end{tabular}

Fonte: Elaboración propia

\subsection{TELEVISIÓN}

O 93,8\% de menores de 16 anos ve a televisión de xeito ocasional ou frecuentemente, porcentaxe que descende ata o $62,1 \%$ cando se trata da visualización de contidos televisivos en lingua galega.

\section{Consumo de televisión e televisión en galego de menores de 16 anos}

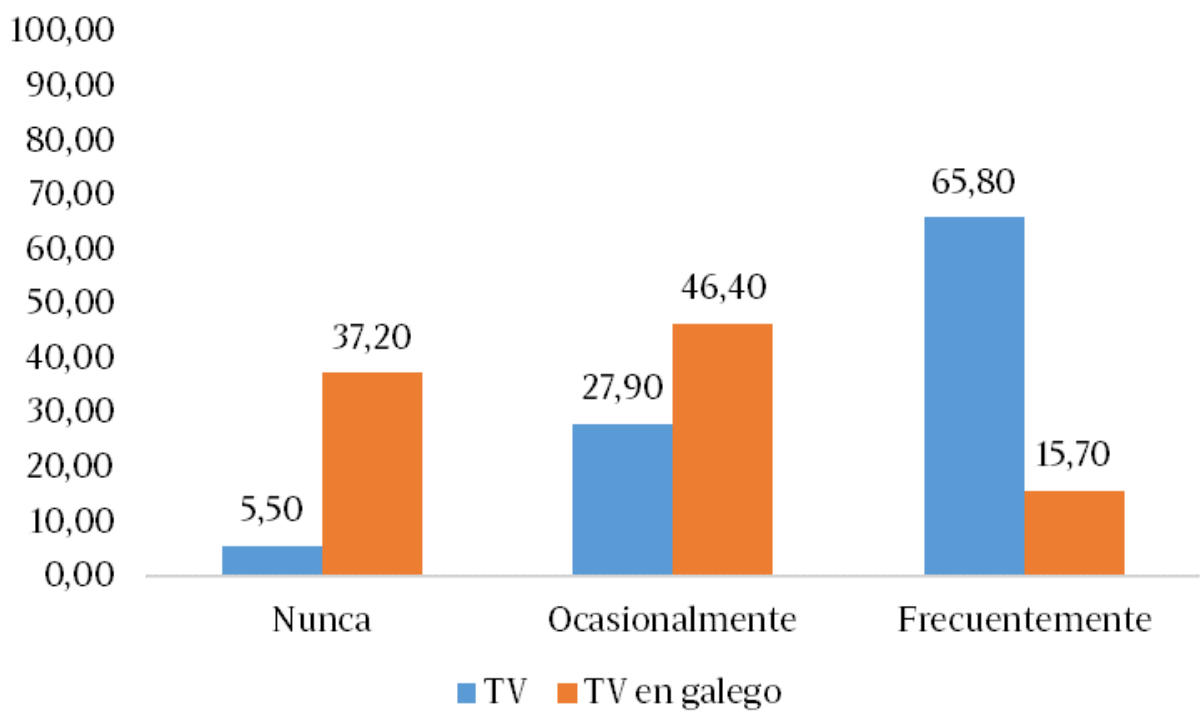

Fonte: Elaboración propia

A análise demostra que os menores de 16 anos que consomen máis contidos televisivos en galego son os fillos/as das persoas enquisadas que aprenderon a falar neste idioma, seguidos polos que o fixeron tanto en galego como en castelán. Un 78\% dos nenos e nenas que aprenderon a falar en galego adoita ver a televisión nesta lingua e, entre estes, un 23,73\% faino frecuentemente e un 54,24\% en ocasións. $O$ índice de frecuencia baixa lixeiramente no caso de que os fillos e fillas das persoas enquisadas aprendesen a falar nas dúas linguas $(20,15 \%$ con frecuencia e un 44,78\% ocasionalmente) e descende 14 puntos porcentuais nos que aprenderon só en castelán, aínda que un 47,43\% dos menores que pertencen a este grupo si que a ve en ocasións. 


\section{Consumo de televisión en galego de menores de 16 anos segundo a lingua en que aprenderon a falar os fillos/as das persoas enquisadas}

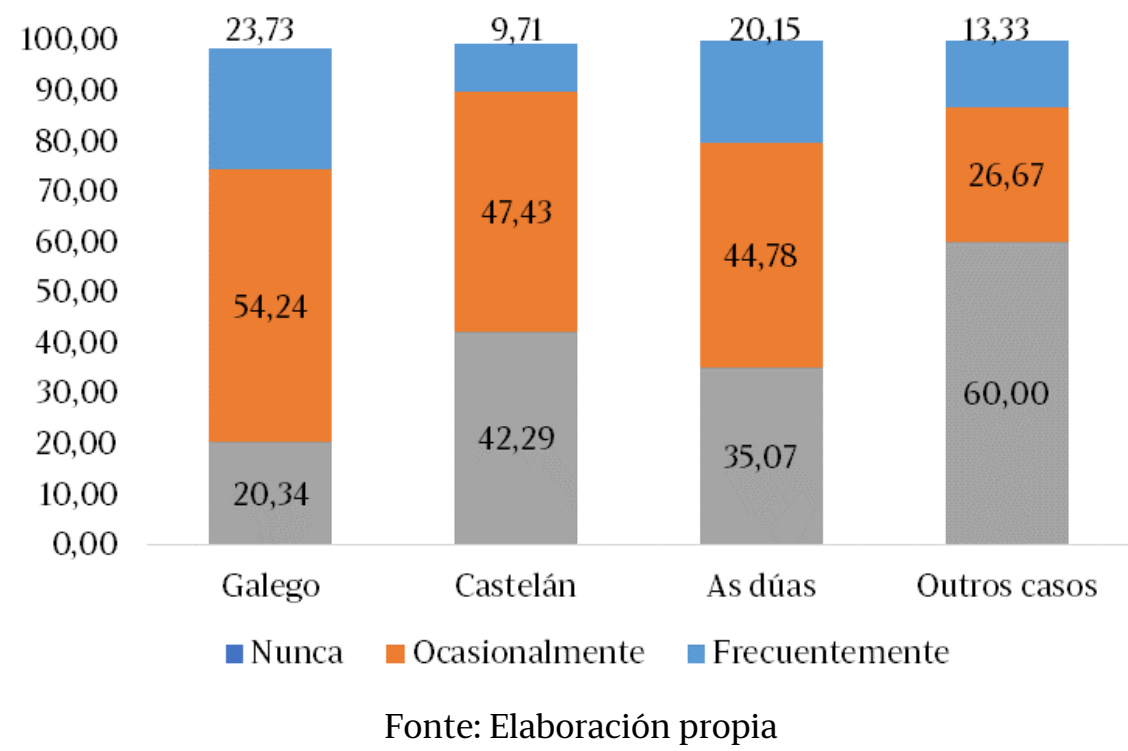

Outra das variables relacionadas coa anterior é a lingua habitual de expresión das persoas enquisadas. Neste caso, é interesante comprobar que os menores de 16 anos que conviven con adultos que falan outros idiomas ademais do castelán e o galego conforman o grupo con maior porcentaxe de visualización de televisión en galego, case o $91 \%$, dos que un $36,36 \%$ o fai frecuentemente. Tras este grupo atópanse os menores que residen con persoas que só falan galego: un $68 \%$ consome contidos televisivos en lingua galega, dos cales un $25,33 \%$ o fai con frecuencia. A continuación están os que viven con persoas que falan máis galego que castelán (65\%) e, finalmente, os que viven coas que falan máis castelán que galego $(60,6 \%)$. Porén, case o $46 \%$ dos menores que conviven con monolingües en castelán non ve nunca contidos en galego.

\section{Consumo de televisión en galego de menores de 16 anos segundo a lingua habitual de expresión das persoas enquisadas}

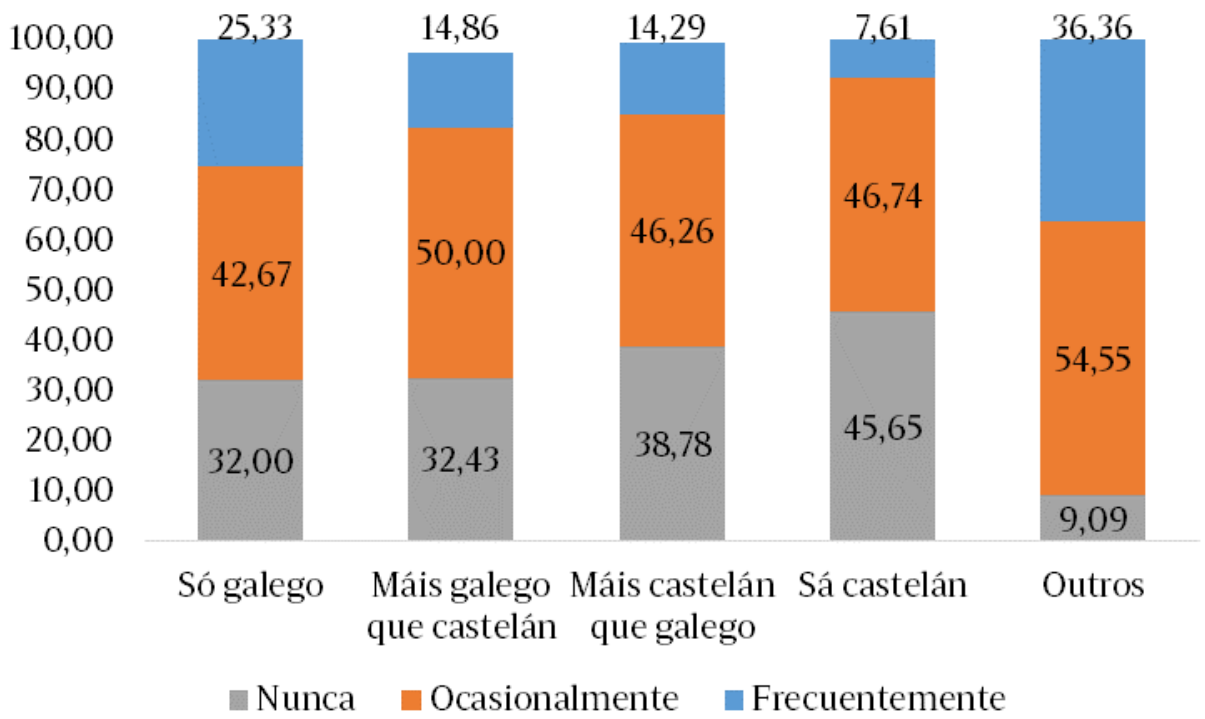

Fonte: Elaboración propia 
Os menores que viven con persoas asalariadas son os que máis consomen televisión en galego (65,7\%), aínda que con menos frecuencia que os que residen con persoas que realizan labores do fogar ou desempregadas $(14,8 \%$ fronte ao $33,3 \%$ e 22,9\% respectivamente). A visualización frecuente é nula entre os nenos e nenas que conviven con estudantes, mentres que a ocasional é moi elevada $(63,6 \%)$.

Consumo de televisión en galego de menores de 16 anos segundo a ocupación das persoas enquisadas

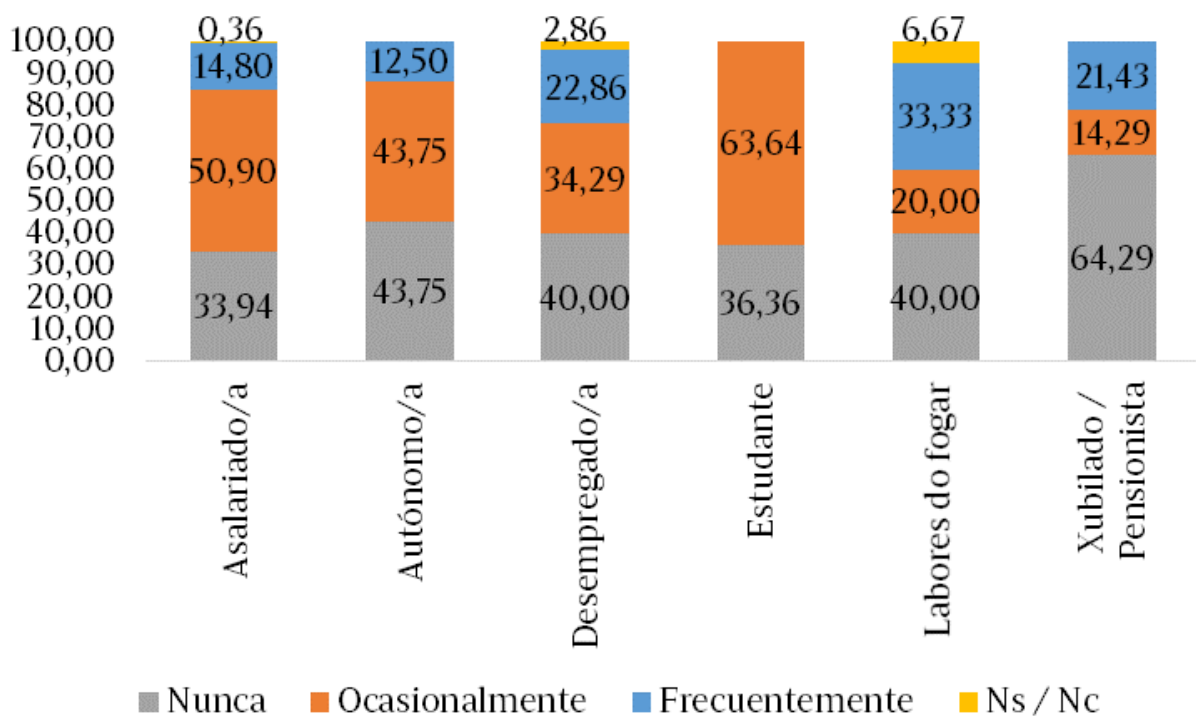

Fonte: Elaboración propia 


\subsection{CONTIDOS AUDIOVISUAIS}

Máis da metade das persoas menores de 16 anos non consome nunca contidos audiovisuais en galego. Tan só un $10 \%$ o fai con frecuencia, porcentaxe que ascende ata o 60,6\% cando se trata de contidos audiovisuais en xeral.

\section{Consumo de contidos audiovisuais e contidos audiovisuais en galego} entre menores de 16 anos

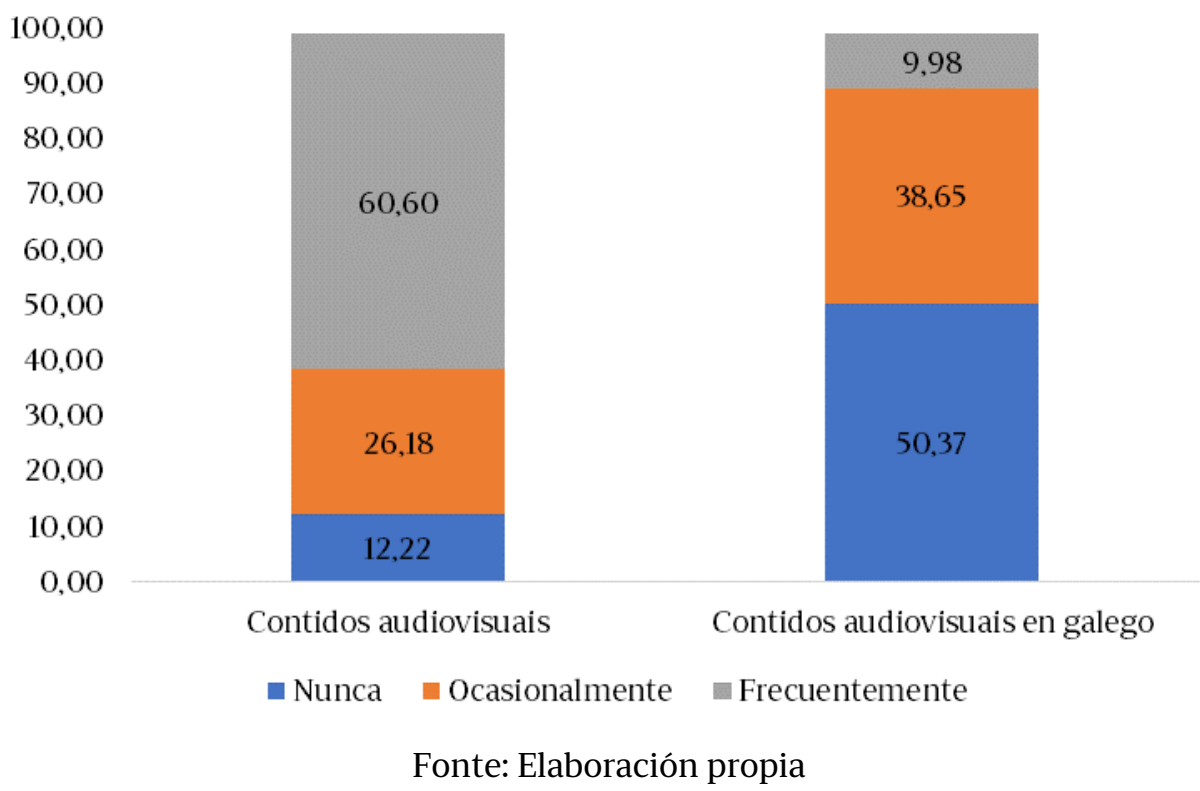

As variables independentes que resultaron significativas no cruzamento cos datos de consumo de contidos audiovisuais por parte de menores de 16 anos son: a asistencia ao cine das persoas entrevistadas, o nivel de estudos, a súa ocupación e o nivel de equipamento no fogar.

Hai que salientar que os menores de 16 anos consomen frecuentemente contidos audiovisuais en cotas elevadas, que abranguen dende o $57,6 \%$ no caso de que convivan con persoas que non van nunca ao cine, ao $62,3 \%$ se os adultos van ocasionalmente e ao $60,8 \%$ se o fan con frecuencia, tal e como se mostra na seguinte táboa.

\section{Consumo de contidos audiovisuais de menores de 16 anos segundo se as persoas enquisadas van ao cine}

Asistencia ao cine (persoas enquisadas)

\begin{tabular}{lccc} 
Consumo de contidos audiovisuais & Nunca & Ocasionalmente & Frecuentemente \\
\hline Nunca & 22,6 & 7,0 & 12,7 \\
Ocasionalmente & 18,9 & 29,8 & 26,6 \\
Frecuentemente & 57,6 & 62,3 & 60,8 \\
\hline
\end{tabular}

Fonte: Elaboración propia

O nivel de equipamento no fogar ten grande influencia no consumo audiovisual de menores de 16 anos: canto maior equipamento haxa no fogar, máis contidos audiovisuais consomen. Case o $91 \%$ dos menores que residen en fogares cun alto nivel de equipamento cultural consome contidos audiovisuais, dos cales unha elevada porcentaxe $(66,5 \%)$ o fai frecuentemente. A continuación están 
os menores que viven en fogares cun nivel medio ou baixo (82\%). Neste último caso a frecuencia no consumo é 25,3 puntos porcentuais inferior ao primeiro grupo, como se pode observar na gráfica.

\section{Consumo de contidos audiovisuais de menores de 16 anos segundo o nivel de equipamento do fogar}

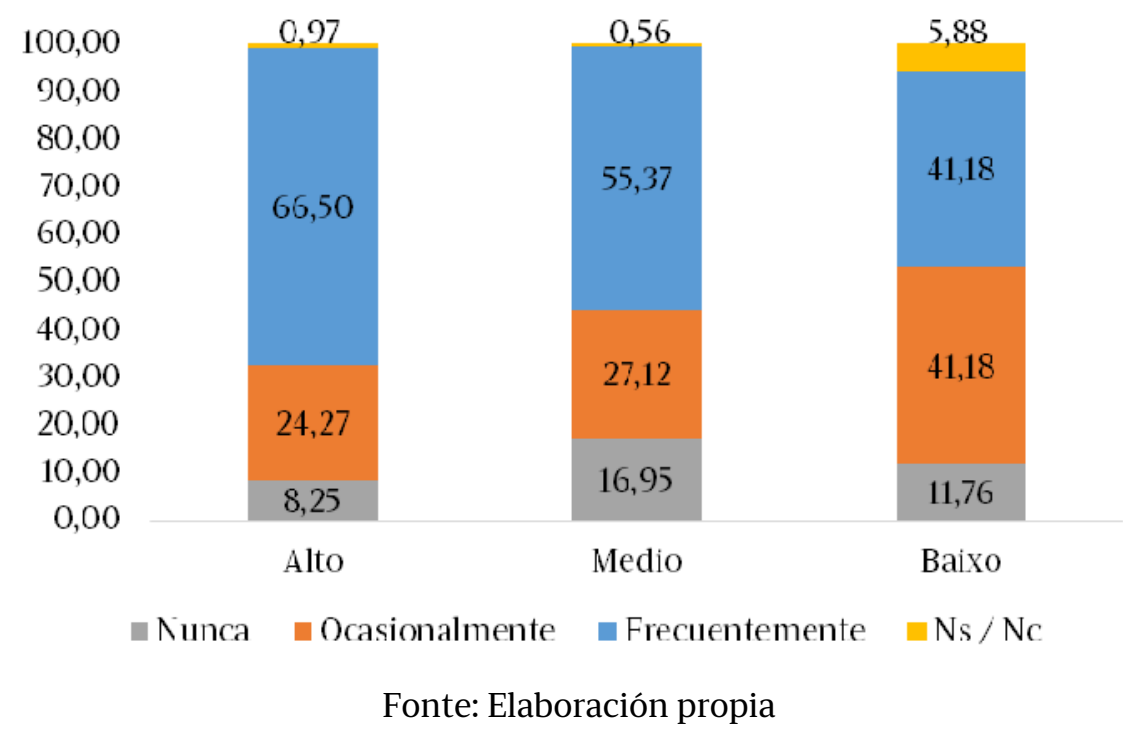

En relación coa repercusión que a ocupación das persoas enquisadas pode ter con esta variable entre menores de 16 anos, comprobouse que case o $91 \%$ dos que viven con estudantes consome contidos audiovisuais, cunha cota de frecuencia moi elevada $(81,8 \%)$. O consumo ocasional e frecuente entre quen reside con adultos en situación de desemprego supera o 91\%, aínda que a frecuencia é menor que no caso anterior $(71,4 \%)$. Con respecto a menores que conviven con persoas asalariadas, un $66,5 \%$ interésase frecuentemente polos contidos audiovisuais e un $28,2 \%$ en ocasións.

Consumo de contidos audiovisuais dos menores de 16 anos segundo a ocupación das persoas enquisadas

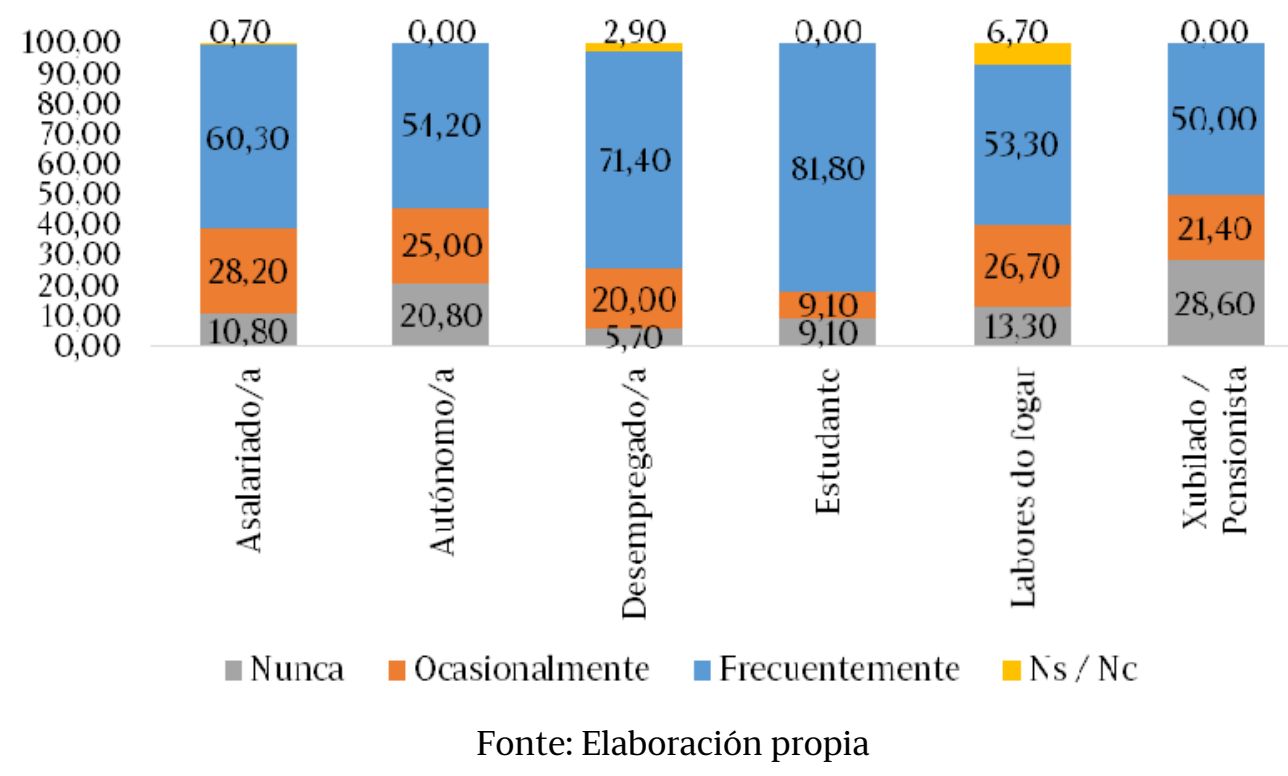


Todos os menores de 16 anos que conviven con persoas que contan con estudos universitarios medios consomen contidos audiovisuais, cun índice de frecuencia próximo ao 70\%. No extremo oposto sitúanse os rapaces que residen con adultos que cursaron estudos primarios ou similares, dos cales un 54,84\% consome contidos audiovisuais frecuentemente.

Consumo de contidos audiovisuais entre os menores de 16 anos segundo o nivel de estudos das persoas enquisadas

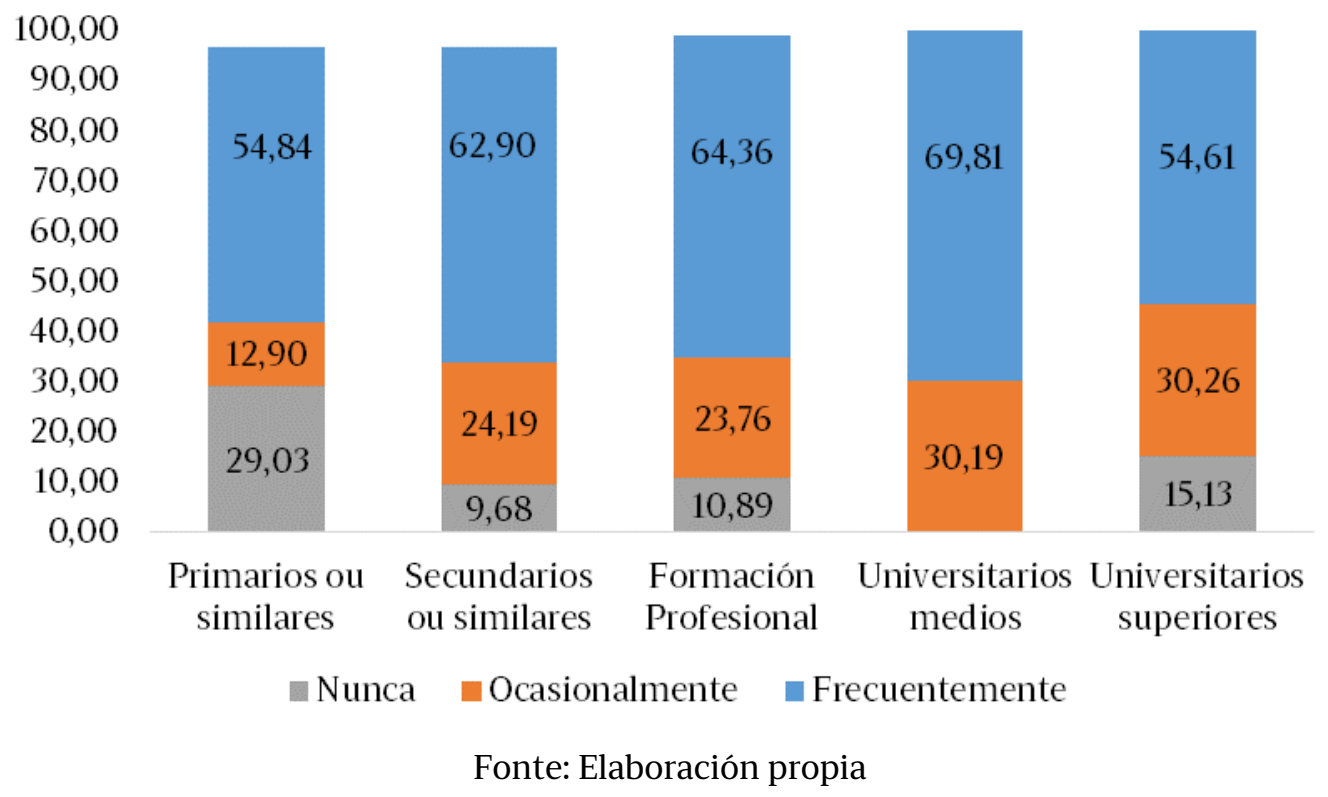

Cando se aborda o consumo de contidos audiovisuais en galego, obtéñense tres variables de influencia nos menores: a lingua de expresión habitual das persoas enquisadas, a súa ocupación e o nivel de ingresos do fogar. No primeiro caso verifícase que, cando a persoa entrevistada é galegofalante, os menores que viven no seu fogar consomen máis contidos audiovisuais en galego (un 60\%), 11 puntos porcentuais por riba dos que falan máis galego que castelán. O 57,6\% dos rapaces e rapazas que residen con adultos que só falan castelán non consome nunca contidos audiovisuais en galego. 
Consumo de contidos audiovisuais en galego de menores de 16 anos segundo a lingua de expresión das persoas enquisadas

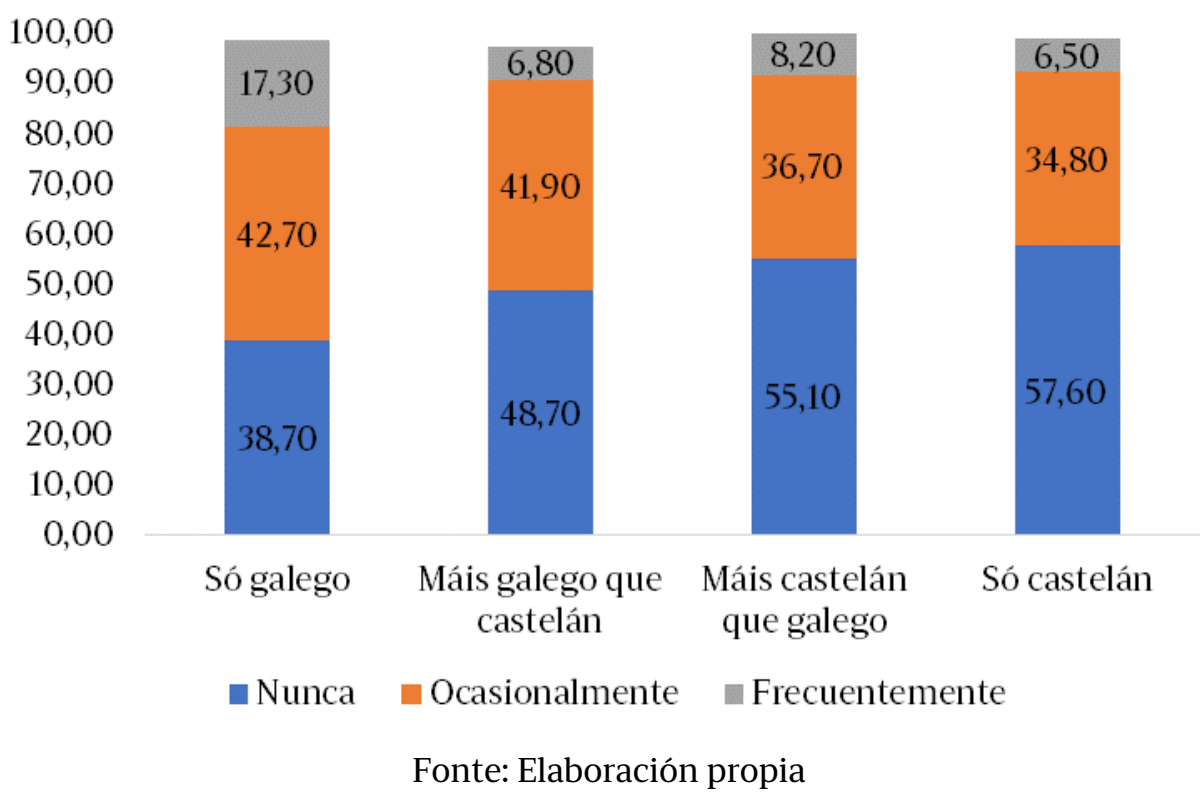

O nivel de ingresos dos fogares acostuma ser un acicate para o consumo de produtos culturais en galego. Neste caso e por primeira vez neste capítulo, o índice máis alto de frecuencia de consumo audiovisual en galego correspóndelles a menores que viven en fogares con ingresos inferiores aos 1.000 euros (un $23,5 \%$ ), un dato que cómpre tomar con certa prudencia, xa que este grupo conta cun elevado índice de respostas "Non sabe, non contesta" (11,8\%).

\section{Consumo de contidos audiovisuais de menores de 16 anos segundo o nivel de ingresos do fogar}

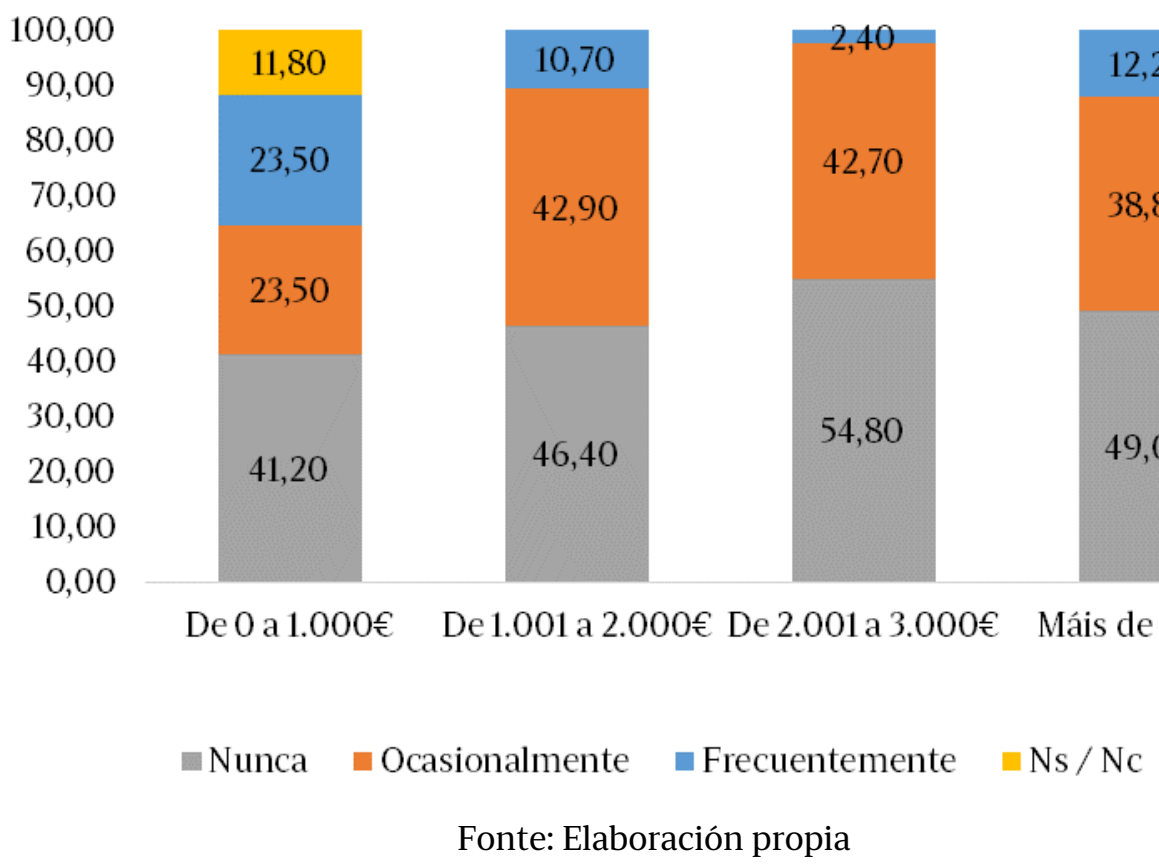

Tendo en conta a ocupación das persoas enquisadas, os menores que consomen máis contidos audiovisuais en galego son os que conviven con estudan- 
tes (un 63,6\%), seguidos polos que están con persoas que realizan tarefas do fogar $(60 \%)$ e desempregadas $(51,4 \%)$. Os menores que menos consomen este produto cultural son os que conviven con autónomos/as e asalariados/as.

Consumo de contidos audiovisuais en galego de menores de 16 anos segundo a ocupación das persoas enquisadas

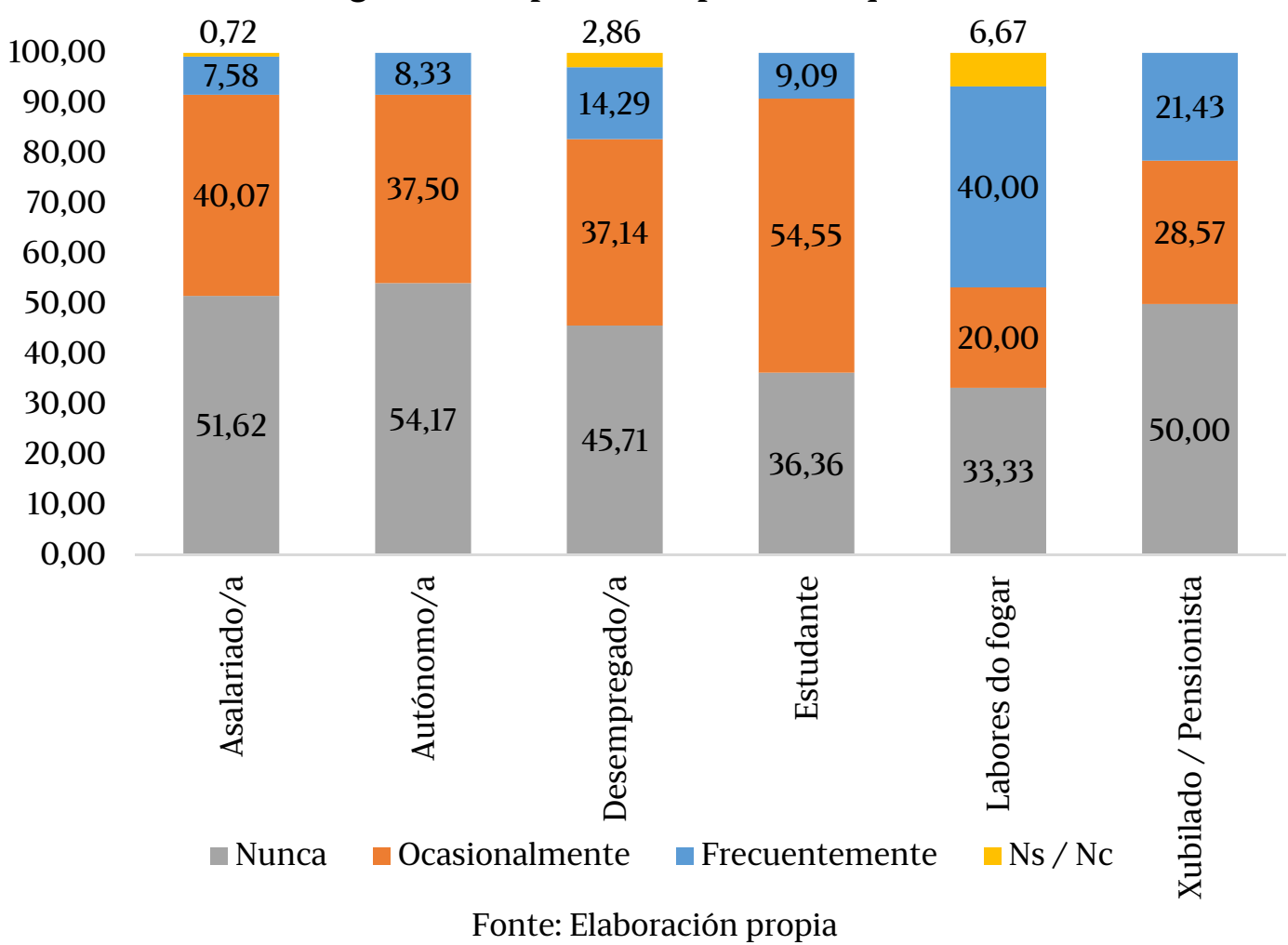




\subsection{XOGO TRADICIONAL E VIDEOXOGOS}

O 84\% de menores de 16 anos consome xogos (tradicional ou videoxogos), tanto de xeito ocasional como frecuentemente. Esta porcentaxe diminúe en 58 puntos cando se trata de xogos en galego, os cales son consumidos só pola cuarta parte dos nenos e nenas, tal e como se mostra na gráfica.

Consumo de xogos e xogos en galego entre menores de 16 anos no fogar

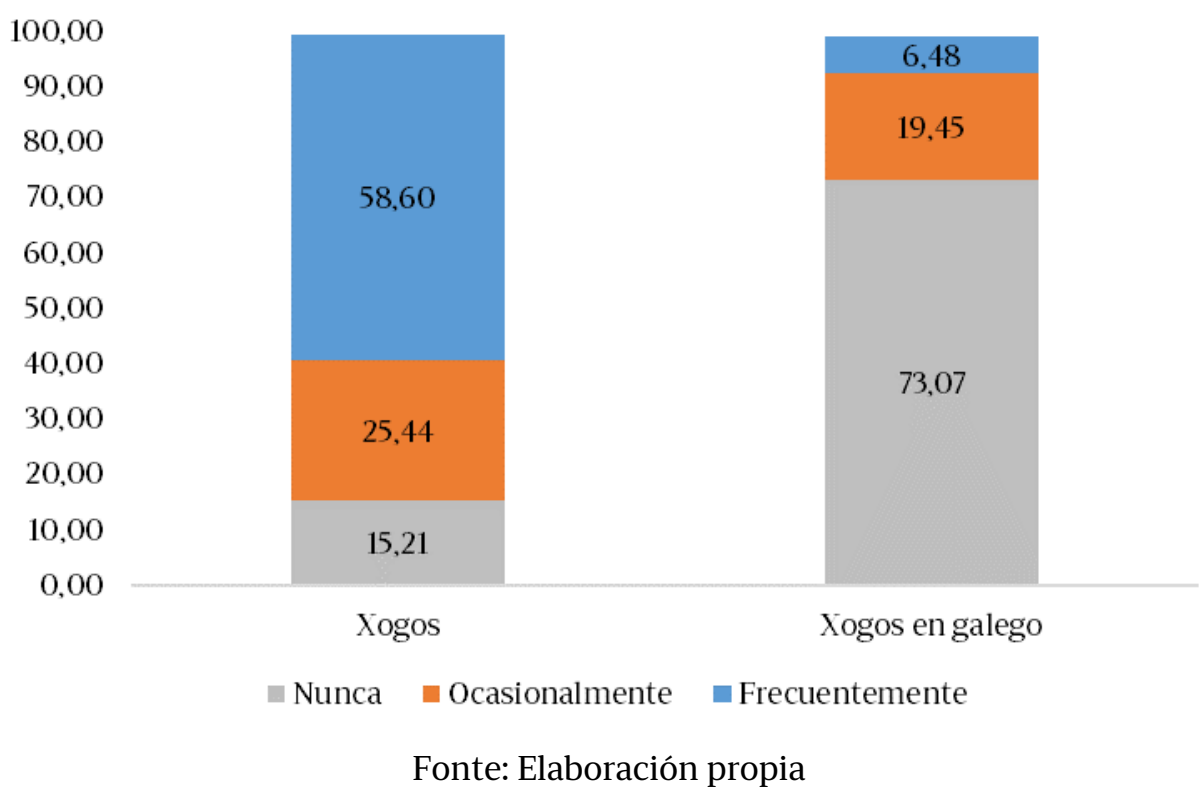

O grao de equipamento do fogar das persoas entrevistadas inflúe de xeito significativo no consumo de xogos entre menores de 16 anos. Máis do $91 \%$ dos rapaces e rapazas que residen en fogares cun alto nivel de equipamento practica algún tipo de xogo, dos cales un $66,5 \%$ o fai frecuentemente.

Consumo de xogos entre menores de 16 anos segundo o nivel de equipamento do fogar

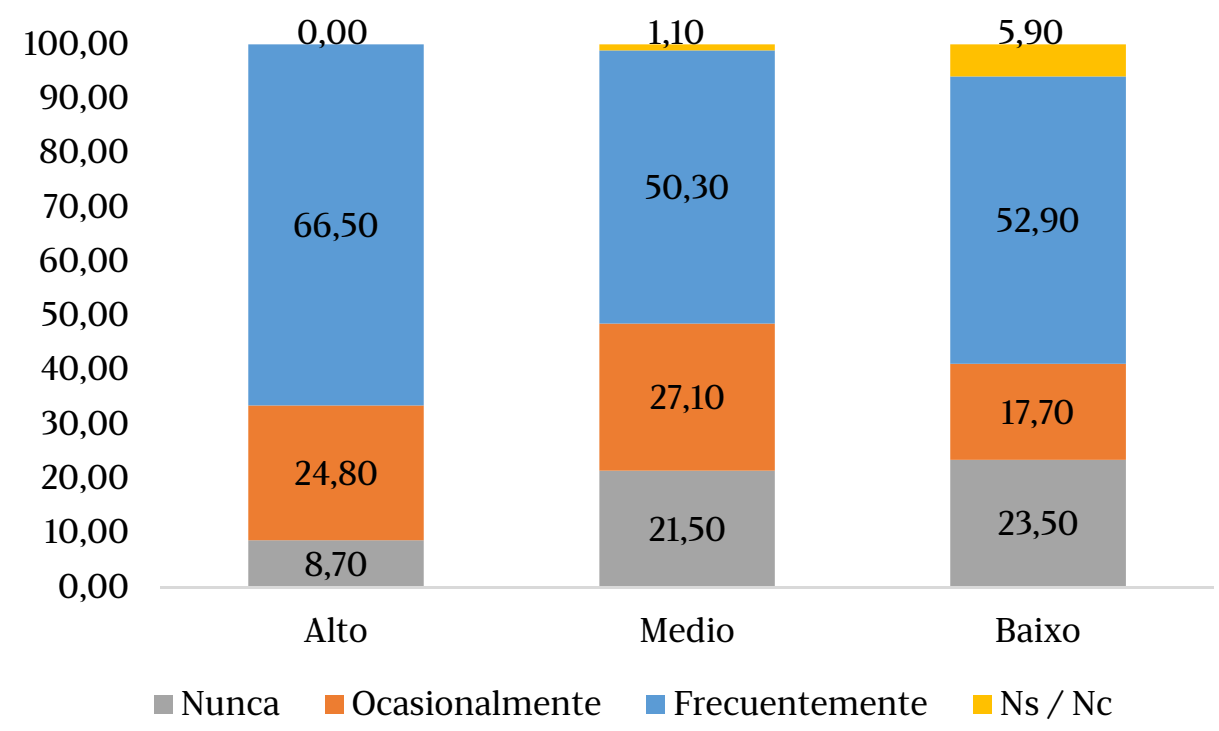

Fonte: Elaboración propia 
Como se pode observar na gráfica anterior, a media que descende o grao de equipamento tamén diminúe este consumo a un 77,4\% nos fogares cun grao de equipamento medio e a un 70,6\% cun nivel baixo. Neste último caso, a frecuencia é lixeiramente maior que no anterior, un 52,9\% fronte a un 50,3\%, aínda que a interpretación deste dato pode estar condicionada polo alto índice de persoas deste grupo que non responderon (5,9\%).

A pesar do baixo consumo de xogos en galego entre menores de 16 anos, constátase que a variable da lingua en que aprenderon a falar os fillos e fillas das persoas enquisadas repercute no consumo de xogos en galego entre menores.

\section{Consumo de xogos en galego entre menores de 16 anos segundo a lingua en que aprenderon a falar os fillos/as das persoas enquisadas}

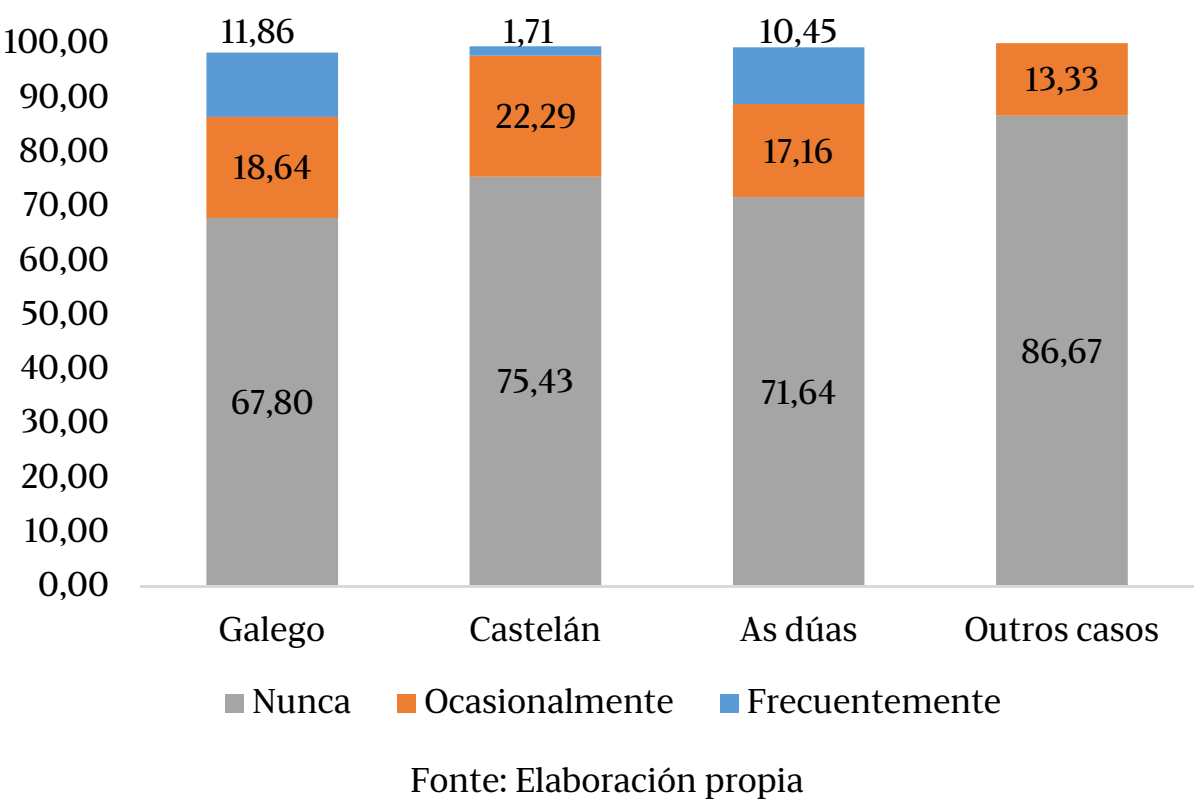

Tal e como se comentaba con anterioridade, pódese demostrar que as persoas que aprenderon a falar ou ben en galego ou ben en galego e castelán son as que máis practican algún tipo de xogo, un 30,5\% e un 27,6\% respectivamente, cunha frecuencia tamén máis alta no resto dos grupos $(11,86 \%$ e $10,45 \%)$, tal e como se mostra na anterior gráfica. 


\section{CONTIDOS CULTURAIS MÁIS IMPORTANTES QUE CÓMPRE POTENCIAR}

Neste apartado analízase cales son os contidos da oferta cultural dirixida á poboación galega menor de 16 anos que habería que mellorar, segundo a importancia que lle outorgan as persoas entrevistadas a través da enquisa. Con este obxectivo e a través dun cuestionario, solicitóuselles ás persoas enquisadas que, de entre todos os contidos que se abordan neste informe, seleccionasen e enumerasen por orde de relevancia os tres que consideren que é fundamental que se fomenten. Trátase dunha pregunta aberta con resposta espontánea e múltiple, na que as persoas enquisadas son libres de responder o que desexen, xa que non se lles presentan opcións predeterminadas. Cómpre salientar que a maior parte da poboación entrevistada (un 72\%) achega algunha suxestión a este respecto.

Nunha análise inicial estúdase especificamente a primeira mención sinalada na resposta. O resultado que se obtén baixo este filtro é que a lectura (11\%), os contidos audiovisuais $(7,56 \%)$, os contidos educativos $(6,22 \%)$ e os xogos tradicionais e educativos (5,78\%) son os indicados como os máis importantes de cara á súa potenciación. Por detrás destes contidos atópanse o teatro, a música e o cine, con algo máis do 3\%, como mostra a gráfica que vai a continuación. 


\section{Contidos culturais en galego para menores de 16 anos que cómpre potenciar9}

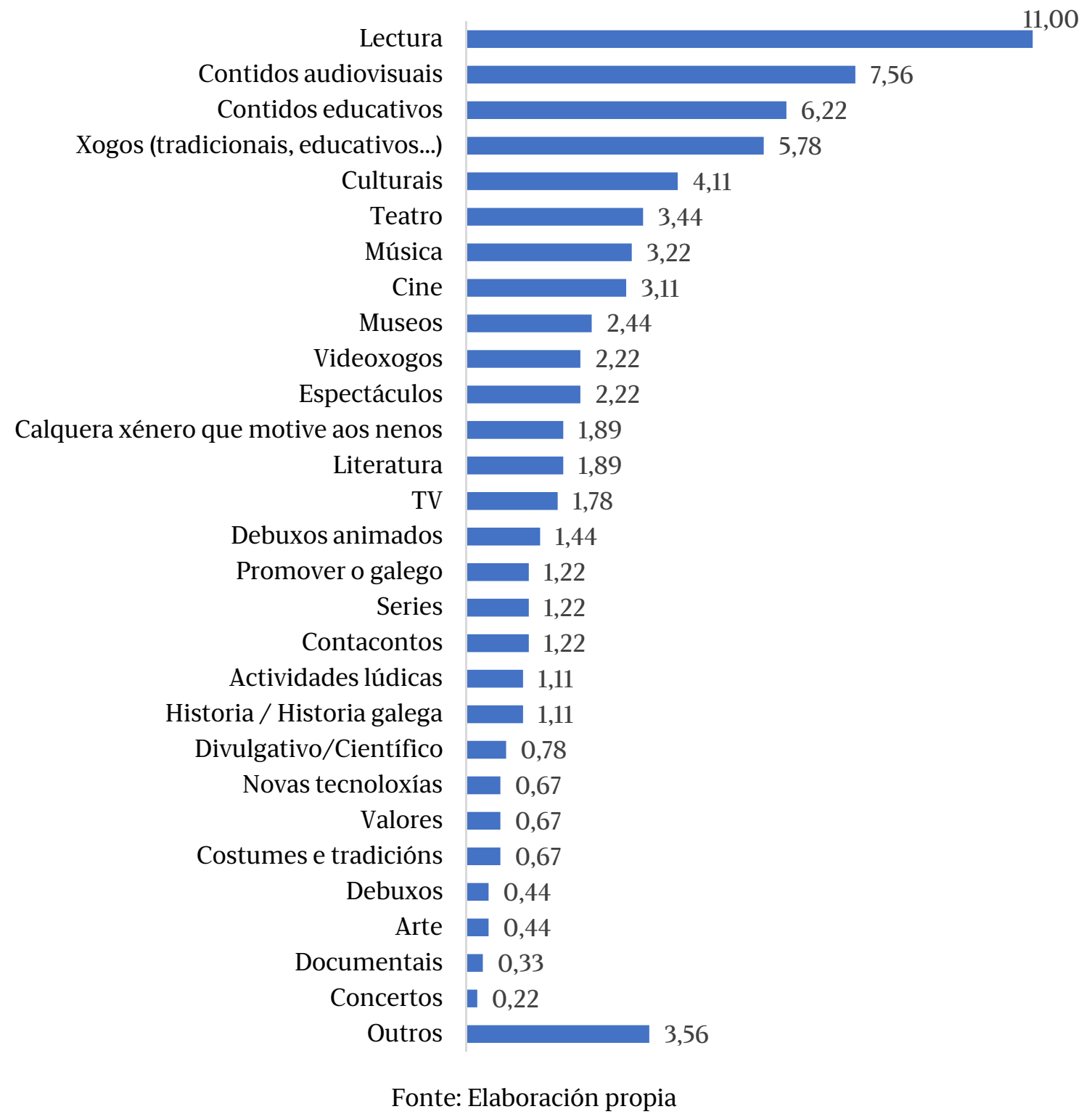

Os resultados extraídos varían ao analizar o número total de mencións das respostas. Con todo, tres dos cinco contidos que resultaban máis valorados na análise anterior tamén o son nesta: a lectura, que segue a ser a máis relevante cun $16 \%$ de citacións, os xogos tradicionais e educativos cun 12\%, que pasan do cuarto lugar en importancia ao segundo, e os contidos audiovisuais cun 10,78\%, que baixan da segunda posición á cuarta. O terceiro contido máis importante para as persoas entrevistadas, unha vez analizadas todas as mencións, sería o cine, cun 11,56\% de respostas e, en quinto lugar, o teatro, cun 8,56\%. Quedan fóra das primeiras cinco posicións tanto os contidos educativos coma os culturais, que se sitúan en sexto e oitavo lugar. O sétimo contido elixido polas persoas entrevistadas sería a música (7\%).

\footnotetext{
${ }^{9}$ Análise da primeira mención da resposta.
} 


\section{Contidos culturais en galego para menores de 16 anos que cómpre potenciar ${ }^{10}$}

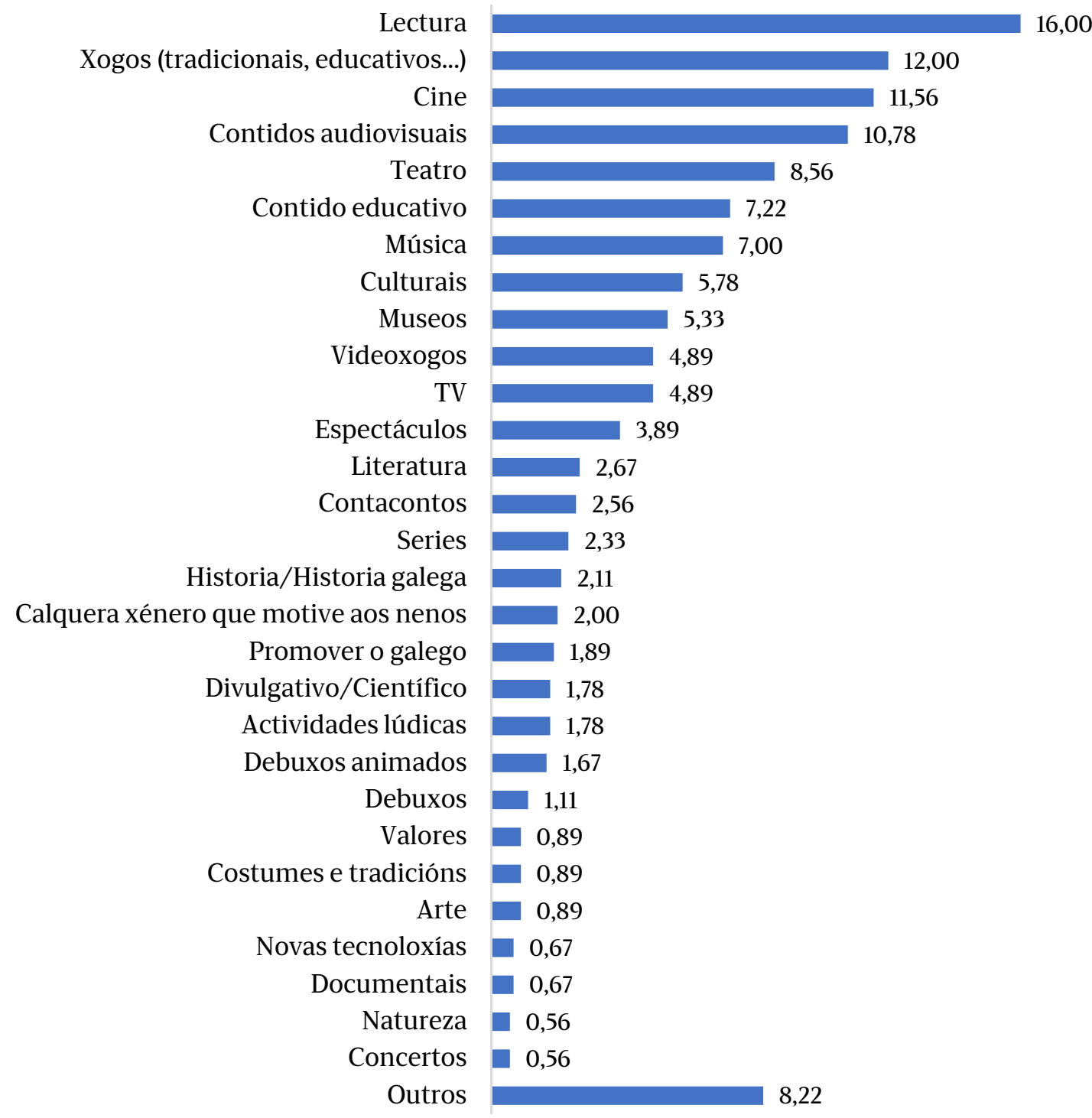

Fonte: Elaboración propia

A idade das persoas enquisadas resultou moi significativa nesta análise. A continuación estúdanse os contidos culturais que se deberían potenciar sinalados polos distintos grupos de idade. Como se pode observar na seguinte táboa, para a poboación de 30 a 44 anos e de 45 a 64 anos, as cinco actividades que máis mencionan coinciden coas obtidas na análise global, é dicir, a lectura, os xogos tradicionais e educativos, o cine, os contidos audiovisuais e o teatro. Estes resultados varían ao estudar as respostas da poboación de idades comprendidas entre 15 e 29 anos, que elixen os videoxogos como o quinto contido máis importante $(14,1 \%)$, por riba do teatro $(7,1 \%)$. No caso das persoas maiores de 65 anos, lectura e xogos tradicionais e educativos seguen a estar entre os cinco primeiros conti-

\footnotetext{
${ }^{10}$ Análise de todas as mencións da resposta.
} 
dos susceptibles de mellora, igual que nos demais grupos, pero engaden contidos educativos $(7,7 \%)$, culturais $(6,5 \%)$, xunto coa música $(5,2 \%)$.

Contidos culturais en galego para menores de 16 anos que cómpre potenciar, por orde de importancia segundo o grupo de idade

\begin{tabular}{|c|c|c|c|c|c|}
\hline Contidos culturais & 15 a 29 & 30 a 44 & 45 a 64 & $\begin{array}{l}65 \text { e } \\
\text { máis }\end{array}$ & Total \\
\hline Lectura & 17,2 & 23,0 & 13,9 & 11,3 & 16,0 \\
\hline Xogos (tradicionais, educativos...) & 17,2 & 14,0 & 12,3 & 7,7 & 12,0 \\
\hline Cine & 15,2 & 15,2 & 13,2 & 4,4 & 11,6 \\
\hline Contido audiovisuais & 22,2 & 12,3 & 11,0 & 4,4 & 10,8 \\
\hline Teatro & 7,1 & 13,2 & 8,7 & 4,4 & 8,6 \\
\hline Contido educativo & 3,0 & 7,8 & 7,7 & 7,7 & 7,2 \\
\hline Música & 9,1 & 6,6 & 8,1 & 5,2 & 7,0 \\
\hline Culturais & 5,1 & 3,7 & 7,1 & 6,5 & 5,8 \\
\hline Museos & 5,1 & 9,9 & 4,2 & 2,4 & 5,3 \\
\hline Videoxogos & 14,1 & 3,3 & 5,8 & 1,6 & 4,9 \\
\hline TV & 7,1 & 7,8 & 4,5 & 1,6 & 4,9 \\
\hline Espectáculos & 4,0 & 4,5 & 4,5 & 2,4 & 3,9 \\
\hline Literatura & 3,0 & 2,5 & 3,9 & 1,2 & 2,7 \\
\hline Contacontos & 1,0 & 4,9 & 1,6 & 2,0 & 2,6 \\
\hline Series & 2,0 & 2,1 & 3,2 & 1,6 & 2,3 \\
\hline Historia/Historia galega & 0,0 & 1,2 & 2,3 & 3,6 & 2,1 \\
\hline $\begin{array}{l}\text { Calquera xénero que motive aos } \\
\text { nenos }\end{array}$ & 3,0 & 2,1 & 1,9 & 1,6 & 2,0 \\
\hline Promover o galego & 1,0 & 1,2 & 1,6 & 3,2 & 1,9 \\
\hline Divulgativo/Científico & 2,0 & 2,9 & 1,3 & 1,2 & 1,8 \\
\hline Actividades lúdicas & 1,0 & 1,2 & 2,3 & 2,0 & 1,8 \\
\hline Debuxos animados & 2,0 & 2,9 & 1,0 & 1,2 & 1,7 \\
\hline Debuxos & 2,0 & 2,9 & 0,3 & 0,0 & 1,1 \\
\hline Valores & 0,0 & 0,4 & 1,6 & 0,8 & 0,9 \\
\hline Costumes e tradicións & 1,0 & 0,4 & 1,3 & 0,8 & 0,9 \\
\hline Arte & 1,0 & 2,5 & 0,3 & 0,0 & 0,9 \\
\hline Novas tecnoloxías & 0,0 & 0,4 & 1,0 & 0,8 & 0,7 \\
\hline Documentais & 0,0 & 0,4 & 0,6 & 1,2 & 0,7 \\
\hline Natureza & 0,0 & 0,4 & 0,6 & 0,8 & 0,6 \\
\hline Concertos & 0,0 & 0,4 & 0,6 & 0,8 & 0,6 \\
\hline Outros & 11,1 & 7,8 & 10,6 & 4,4 & 8,2 \\
\hline
\end{tabular}

Fonte: Elaboración propia

Outro dos indicadores que inflúen nos resultados é a lingua en que falan as persoas enquisadas. Por exemplo, as que falan só falan galego coinciden nos cinco principais contidos culturais que cómpre potenciar cos mencionados a nivel xeral, é dicir, lectura (18,9\%), xogos tradicionais e educativos $(16,8 \%)$, cine e contidos audiovisuais $(8,2 \%)$ e teatro $(7,7 \%)$, o mesmo que sucede coas persoas bilingües (máis galego que castelán ou máis castelán que galego). As persoas entrevistadas que só falan castelán igualan en importancia o contido educativo e os xogos e, por último, as que falan outros idiomas introducen neses cinco contidos 
principais os espectáculos, na mesma porcentaxe que a lectura $(14,7 \%)$ e a música, tamén cun índice porcentual igual aos contidos audiovisuais, un 11,8\%; os xogos tradicionais e educativos son os máis mencionados, cun 17,6\%. Un 3,6\% das persoas que falan galego consideran que se debe potenciar a promoción da lingua galega, fronte ao 2,9\% de quen ou ben só fala castelán ou fala outros idiomas, ao 0,4\% de quen fala máis castelán que galego e ao 1,4\% de quen fala máis galego que castelán.

Contidos culturais en galego para menores de 16 anos que cómpre potenciar, por orde de importancia, segundo o idioma en que falan as persoas enquisadas

\begin{tabular}{|c|c|c|c|c|c|c|}
\hline \multirow[b]{2}{*}{ Contidos culturais } & \multicolumn{6}{|c|}{ Linguas que falan as persoas enquisadas } \\
\hline & $\begin{array}{l}\text { Só gale- } \\
\text { go }\end{array}$ & $\begin{array}{c}\text { Máis } \\
\text { galego } \\
\text { que } \\
\text { castelán }\end{array}$ & $\begin{array}{c}\text { Máis } \\
\text { castelán } \\
\text { que } \\
\text { galego }\end{array}$ & $\begin{array}{l}\text { Só caste- } \\
\text { lán }\end{array}$ & Outros & Total \\
\hline Lectura & 18,9 & 17,9 & 14,2 & 14,5 & 14,7 & 16,2 \\
\hline Xogos (tradicionais, educativos...) & 16,8 & 9,7 & 11,7 & 8,7 & 17,6 & 12,0 \\
\hline Cine & 8,2 & 12,6 & 13,5 & 10,5 & 8,8 & 11,3 \\
\hline Contidos audiovisuais & 8,2 & 12,1 & 12,1 & 9,9 & 11,8 & 10,8 \\
\hline Teatro & 7,7 & 8,7 & 8,9 & 9,3 & 8,8 & 8,6 \\
\hline Contidos educativos & 6,1 & 5,8 & 8,2 & 8,7 & 2,9 & 7,1 \\
\hline Música & 7,1 & 5,8 & 6,4 & 8,1 & 11,8 & 7,0 \\
\hline Culturais & 4,6 & 2,4 & 7,1 & 8,7 & 8,8 & 5,8 \\
\hline Museos & 2,6 & 5,8 & 6,7 & 5,8 & 5,9 & 5,4 \\
\hline Videoxogos & 3,6 & 3,4 & 7,1 & 4,1 & 8,8 & 4,9 \\
\hline TV & 5,1 & 4,8 & 5,7 & 3,5 & 5,9 & 4,9 \\
\hline Espectáculos & 4,6 & 2,9 & 3,2 & 3,5 & 14,7 & 3,9 \\
\hline Literatura & 4,1 & 1,0 & 2,1 & 3,5 & 2,9 & 2,6 \\
\hline Contacontos & 2,6 & 1,4 & 3,2 & 2,9 & 2,9 & 2,6 \\
\hline Series & 2,0 & 4,3 & 1,1 & 1,7 & 5,9 & 2,4 \\
\hline Historia/Historia galega & 3,6 & 0,5 & 2,1 & 2,3 & 2,9 & 2,1 \\
\hline $\begin{array}{l}\text { Calquera xénero que motive aos } \\
\text { nenos }\end{array}$ & 0,5 & 4,3 & 1,4 & 2,3 & 0,0 & 2,0 \\
\hline Promover o galego & 3,6 & 1,4 & 0,4 & 2,9 & 2,9 & 1,9 \\
\hline Divulgativo/Científico & 1,0 & 1,4 & 2,8 & 1,7 & 0,0 & 1,8 \\
\hline Actividades lúdicas & 1,0 & 1,9 & 1,8 & 2,9 & 0,0 & 1,8 \\
\hline Debuxos animados & 0,5 & 2,9 & 2,1 & 0,6 & 2,9 & 1,7 \\
\hline Debuxos & 1,5 & 1,4 & 0,4 & 0,0 & 5,9 & 1,0 \\
\hline Valores & 0,0 & 1,0 & 1,1 & 1,7 & 0,0 & 0,9 \\
\hline Costumes e tradicións & 2,6 & 0,5 & 0,4 & 0,6 & 0,0 & 0,9 \\
\hline Arte & 0,5 & 0,5 & 0,4 & 1,7 & 5,9 & 0,9 \\
\hline Novas tecnoloxías & 0,0 & 1,0 & 1,1 & 0,6 & 0,0 & 0,7 \\
\hline Documentais & 0,0 & 1,9 & 0,0 & 1,2 & 0,0 & 0,7 \\
\hline Natureza & 0,0 & 1,0 & 0,7 & 0,6 & 0,0 & 0,6 \\
\hline Concertos & 0,0 & 0,5 & 0,7 & 0,6 & 0,0 & 0,4 \\
\hline Outros & 5,1 & 7,2 & 9,6 & 12,8 & 0,0 & 8,3 \\
\hline
\end{tabular}


Unha vez obtidos os anteriores resultados atendendo ás variables de idade e lingua en que falan as persoas enquisadas, analízanse as respostas tendo en conta se hai menores de 16 anos no fogar. No caso dos fogares onde hai menores repítense as cinco mencións principais dos contidos culturais que cómpre potenciar: lectura $(17,7 \%)$, xogos tradicionais e educativos $(13,5 \%)$, cine $(14 \%)$, contidos audiovisuais (12,2\%) e teatro (10,5\%). En cambio, nas familias sen menores de 16 anos no fogar menciónase antes a música (8,4\%, 3,2 puntos porcentuais máis) que o teatro (7\%, 3,5 puntos porcentuais menos). É importante resaltar que os cinco contidos culturais menos nomeados, incluído o número total de mencións, foron os relacionados coa arte, as novas tecnoloxías, os documentais, a natureza e os concertos, todos por debaixo do $1 \%$.

\section{Contidos culturais en galego para menores de 16 anos que cómpre potenciar, por orde de importancia, segundo haxa menores no fogar}

\begin{tabular}{|c|c|c|c|}
\hline Contidos culturais & $\begin{array}{l}\text { Hai menores de } \\
16 \text { no fogar }\end{array}$ & $\begin{array}{l}\text { Non hai meno- } \\
\text { res no fogar }\end{array}$ & Total \\
\hline Lectura & 17,7 & 14,6 & 16,0 \\
\hline Xogos (tradicionais, educativos...) & 13,5 & 10,8 & 12,0 \\
\hline Cine & 14,0 & 9,6 & 11,6 \\
\hline Contidos audiovisuais & 12,2 & 9,6 & 10,8 \\
\hline Teatro & 10,5 & 7,0 & 8,6 \\
\hline Contidos educativos & 7,0 & 7,4 & 7,2 \\
\hline Música & 5,2 & 8,4 & 7,0 \\
\hline Culturais & 5,2 & 6,2 & 5,8 \\
\hline Museos & 8,0 & 3,2 & 5,3 \\
\hline Videoxogos & 3,5 & 6,0 & 4,9 \\
\hline TV & 6,7 & 3,4 & 4,9 \\
\hline Espectáculos & 6,0 & 2,2 & 3,9 \\
\hline Literatura & 3,0 & 2,4 & 2,7 \\
\hline Contacontos & 5,2 & 0,4 & 2,6 \\
\hline Series & 2,0 & 2,6 & 2,3 \\
\hline Historia/Historia galega & 1,0 & 3,0 & 2,1 \\
\hline $\begin{array}{l}\text { Calquera xénero que motive aos } \\
\text { nenos }\end{array}$ & 2,7 & 1,4 & 2,0 \\
\hline Promover o galego & 1,8 & 2,0 & 1,9 \\
\hline Divulgativo/Científico & 2,5 & 1,2 & 1,8 \\
\hline Actividades lúdicas & 2,0 & 1,6 & 1,8 \\
\hline Debuxos animados & 2,2 & 1,2 & 1,7 \\
\hline Debuxos & 1,5 & 0,8 & 1,1 \\
\hline Valores & 1,3 & 0,6 & 0,9 \\
\hline Costumes e tradicións & 0,5 & 1,2 & 0,9 \\
\hline Arte & 1,5 & 0,4 & 0,9 \\
\hline Novas tecnoloxías & 0,3 & 1,0 & 0,7 \\
\hline Documentais & 0,8 & 0,6 & 0,7 \\
\hline Natureza & 0,5 & 0,6 & 0,6 \\
\hline Concertos & 0,3 & 0,8 & 0,6 \\
\hline Outros & 8,2 & 8,2 & 8,2 \\
\hline
\end{tabular}




\section{DISPOSICIÓN OU INTERESE EN AGASALLAR ALGÚN CONTI- DO CULTURAL AOS MENORES DE 16 ANOS}

Este apartado aborda a disposición ou interese da cidadanía en agasallar aos nenos e nenas dos fogares galegos con algún tipo de contido cultural. As variables consideradas para explicar os resultados foron a idade, o sexo, o nivel de estudos rematados, a situación laboral da persoa entrevistada, se hai menores de 16 no fogar, os ingresos mensuais do fogar, a lingua que fala habitualmente a persoa entrevistada, a lingua que aprenderon a falar os nenos e nenas, a tipoloxía do contorno de residencia, a provincia, o tamaño do hábitat de residencia, as actividades culturais realizadas, a subscrición a plataformas de contidos culturais e, por último, o grao de equipamento cultural do fogar.

A valoración desta disposición ou interese levouse a cabo mediante un sistema de puntuación nunha escala que vai de 0 a 10 , onde 0 equivalería a que as persoas enquisadas non estarían nada interesadas e 10 que estarían moi interesadas.

En termos medios, as persoas enquisadas mostran unha disposición relativamente alta, de 7,9 puntos, a regalar algún contido cultural a menores de 16 anos e, no caso particular dos contidos culturais en galego, a vontade redúcese lixeiramente a 7,6 puntos.

\section{Grao de interese en agasallar contidos culturais a menores de 16 anos (Valoración media nunha escala de 0 a 10)}

\begin{tabular}{lcc} 
& Media & Dispersión \\
\hline Contido cultural & 7,9 & 2,4 \\
Contido cultural en galego & 7,6 & 2,8 \\
\hline
\end{tabular}

Fonte: Elaboración propia

Para poder clarificar os resultados, interesa ver a distribución da variable de intención de agasallar contidos culturais en galego, co fin de comprobar como se sitúan as puntuacións na escala. 
Porcentaxe da intención de agasallar a menores de 16 anos con algún contido cultural en galego, segundo o grao de interese (Valoración media nunha escala de 0 a 10)

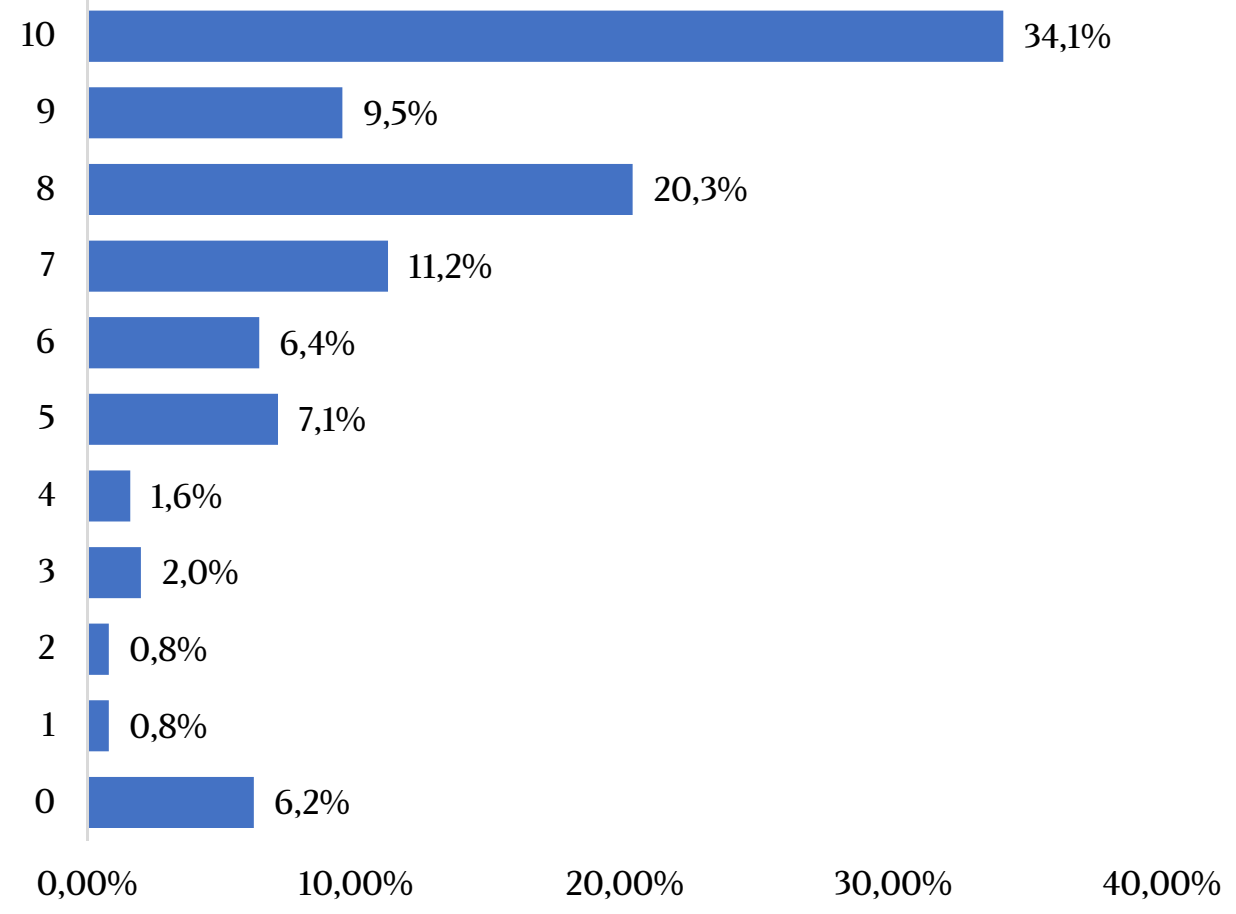

Fonte: Elaboración propia

Destaca o feito de que a resposta maioritaria sexa a que outorga a puntuación máis alta á disposición de agasallar en galego e que dúas de cada tres persoas puntúen esa disposición cun 8 ou máis. En contraste, e como se pode ver na parte baixa da gráfica, existe una porcentaxe pequena da poboación en Galicia $(6,2 \%)$ que non ten ningún interese en regalar produtos en galego. Esa porcentaxe de respostas claramente negativas explica, en parte, a maior dispersión e a media global máis baixa para os produtos en galego.

A continuación preséntase a relación destes resultados coas variables independentes que achegaron diferenzas significativas na distribución das súas categorías. Coa intención de comparar ambas as variables, tanto a intención de ofrecer contido cultural en xeral como en galego para menores de 16 anos, elixíronse aquelas variables independentes nas que, en polo menos un dos casos, resultase significativa.

En xeral, pode concluírse que os menos dispostos a ofrecer algún contido cultural a menores de 16 anos, tanto en galego como en xeral, son os homes con respecto ás mulleres. Cómpre sinalar que, entre as mulleres, son maiores as diferenzas que se dan entre a disposición a regalar produtos culturais en xeral fronte a produtos en galego. 


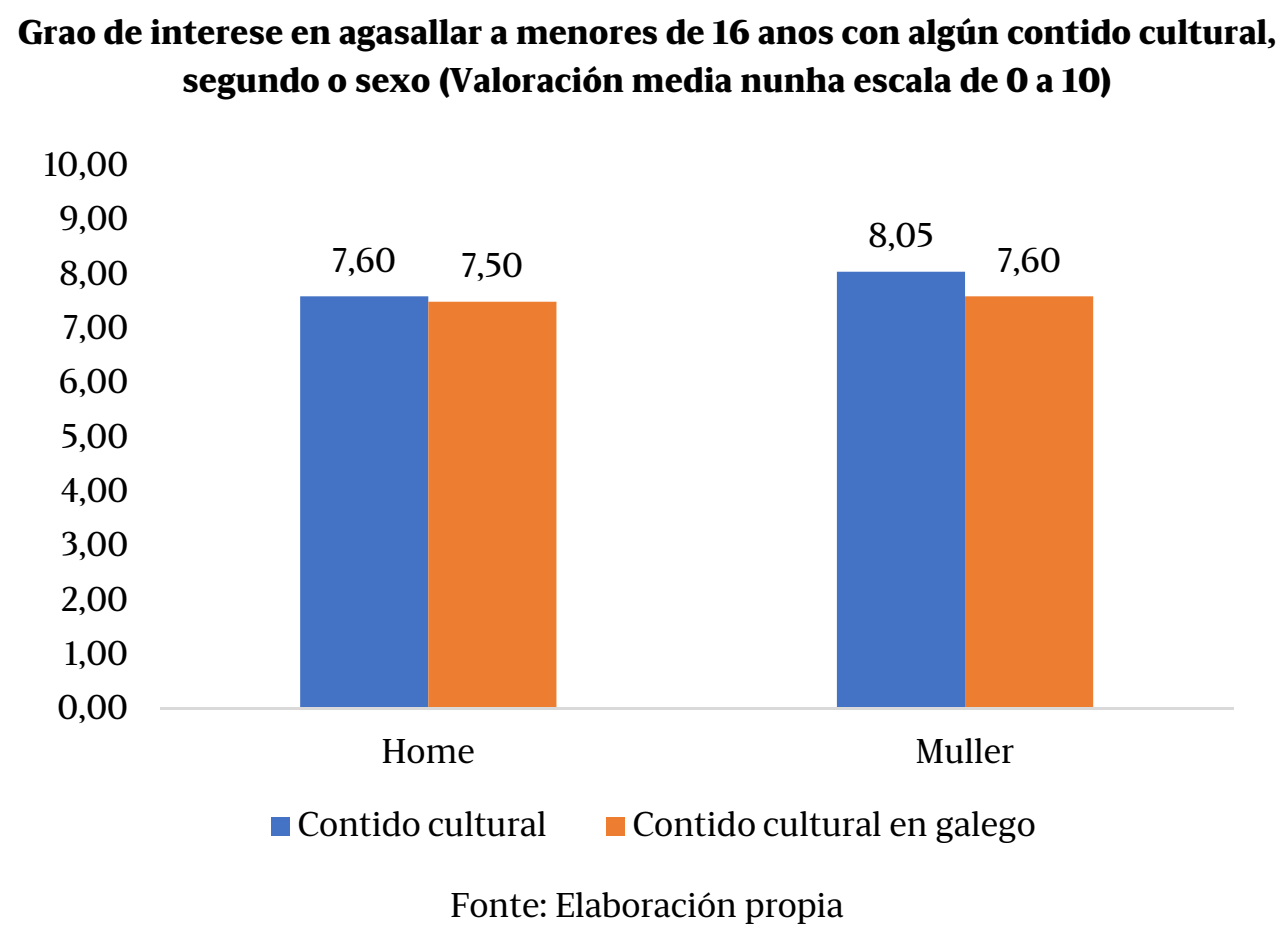

Tamén se atopan en menor disposición de regalar as persoas que non están subscritas a ningunha plataforma dixital de contido cultural en comparación coas que si o están.

\section{Grao de interese en agasallar a menores de 16 anos con algún contido cultural, segundo a} subscrición a algunha plataforma dixital (Valoración media nunha escala de 0 a 10)

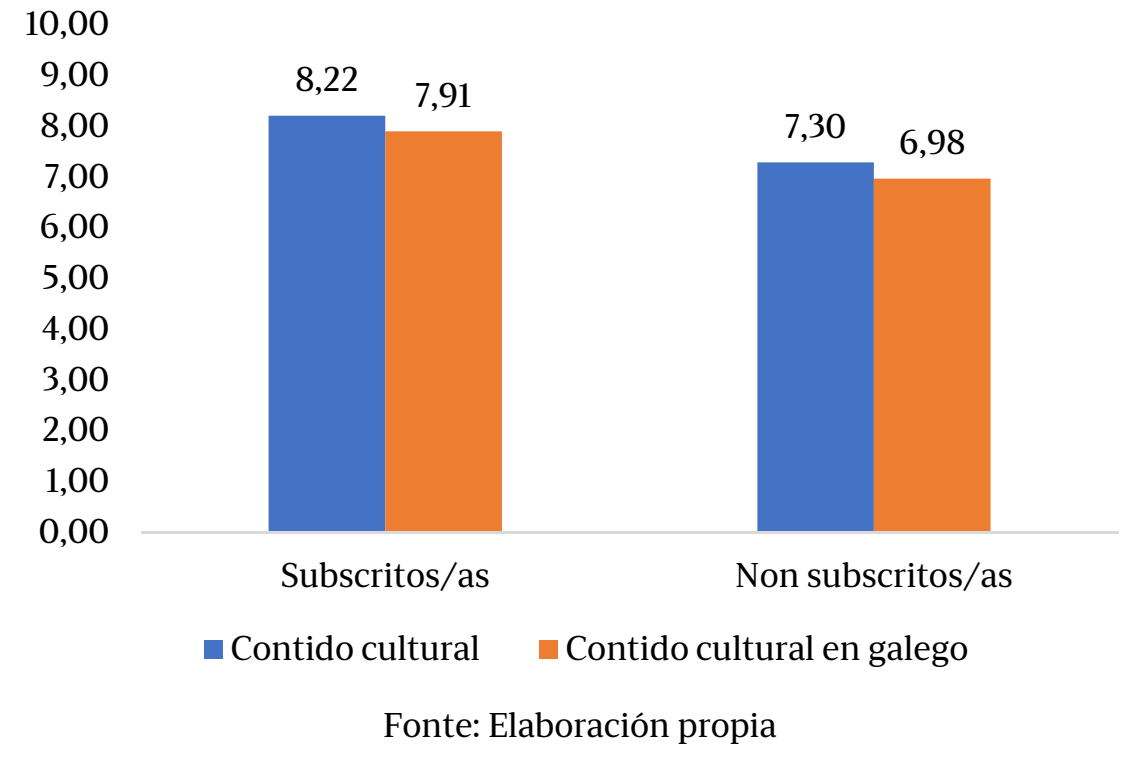

Ademais, as persoas que teñen un nivel baixo de equipamento no fogar son as menos interesadas en agasallar contidos culturais a menores de 16 anos do seu contorno, tanto en galego coma noutras linguas. Canto máis elevado sexa o nivel de equipamento dos fogares, máis aumenta o interese das persoas enquisadas por agasallar contidos culturais. 
Grao de interese en agasallar a menores de 16 anos con algún contido cultural, segundo o nivel de equipamento do fogar (Valoración media nunha escala de 0 a 10)

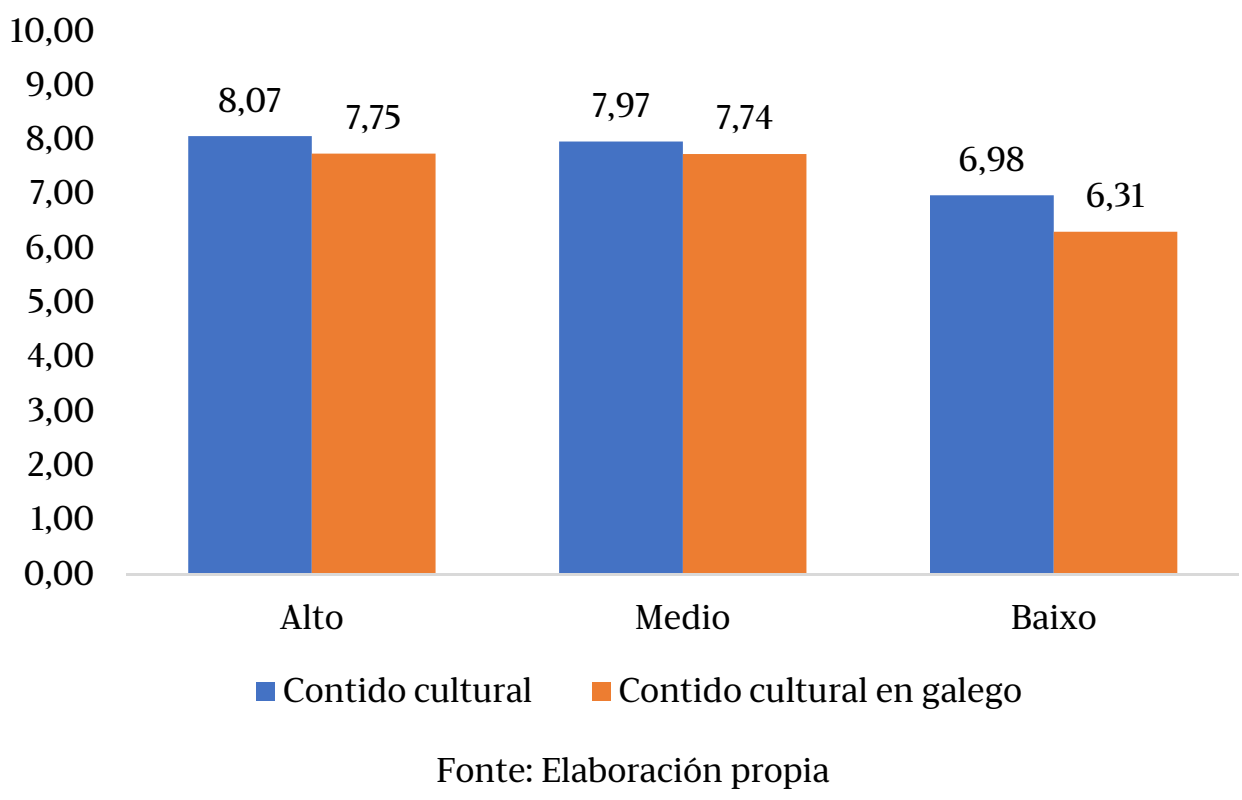

Do mesmo xeito, as persoas que non residen con menores de 16 anos son as que menor intención teñen de ofrecer contidos culturais á rapazada, en comparación coas que si conviven con menores.

Grao de interese en agasallar a menores de 16 anos con algún contido cultural, segundo haxa nenos e nenas no fogar (Valoración media nunha escala de 0 a 10)

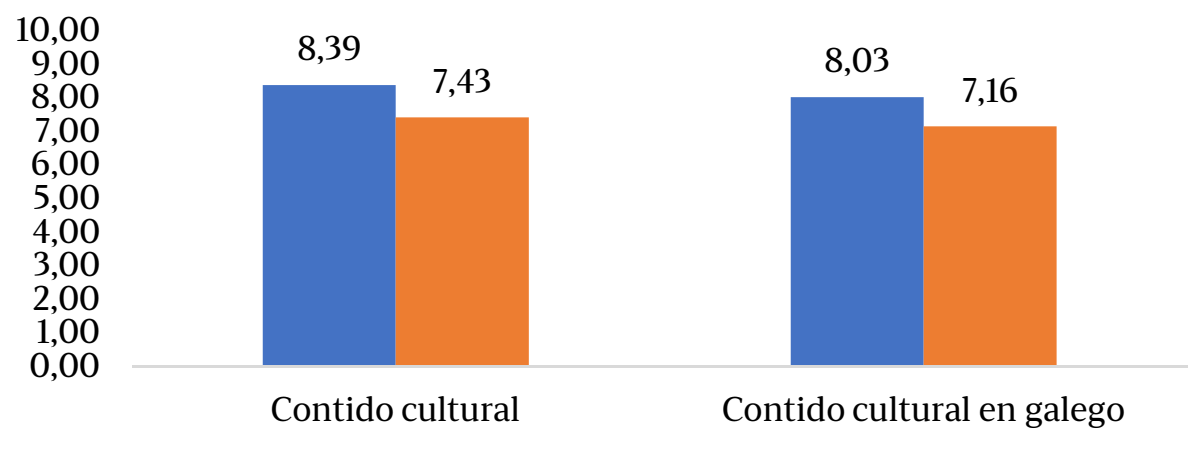

- Hai menores de 16 no fogar $\quad$ Non hai menores no fogar

Fonte: Elaboración propia

Con respecto aos ingresos, en xeral poderíase dicir que a tendencia demostra que, canto maiores sexan os ingresos do fogar, maior é o interese por regalar algún tipo de contido cultural a menores que puidese haber no seu contorno. No treito de ingresos que vai de 1.000 a 2.000 euros de ingresos, a disposición a regalar contidos culturais en galego é lixeiramente superior á de contidos culturais en xeral. 


\section{Grao de interese en agasallar a menores de 16 anos con algún contido cultural, segundo os ingresos do fogar (Valoración media nunha escala de 0 a 10)}

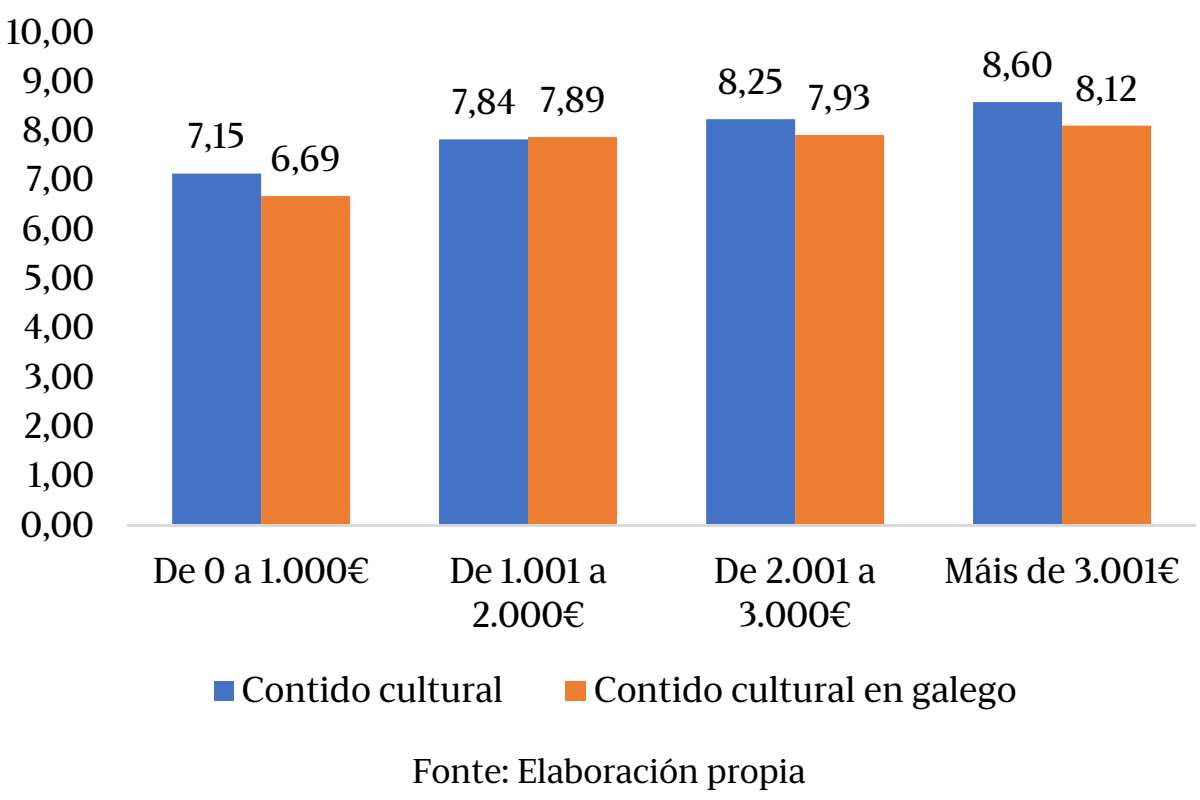

Ao analizar a intención de obsequiar segundo a idade das persoas entrevistadas, pódese observar que o grupo que abrangue a maiores de 65 anos se corresponde co das persoas que están menos dispostas a adquirir contidos culturais para menores de 16 anos e o grupo de 30 a 44 anos de idade é o que mostra máis interese. Entre a xente nova, a disposición a regalar produtos culturais en galego é superior á de regalar produtos culturais en xeral.

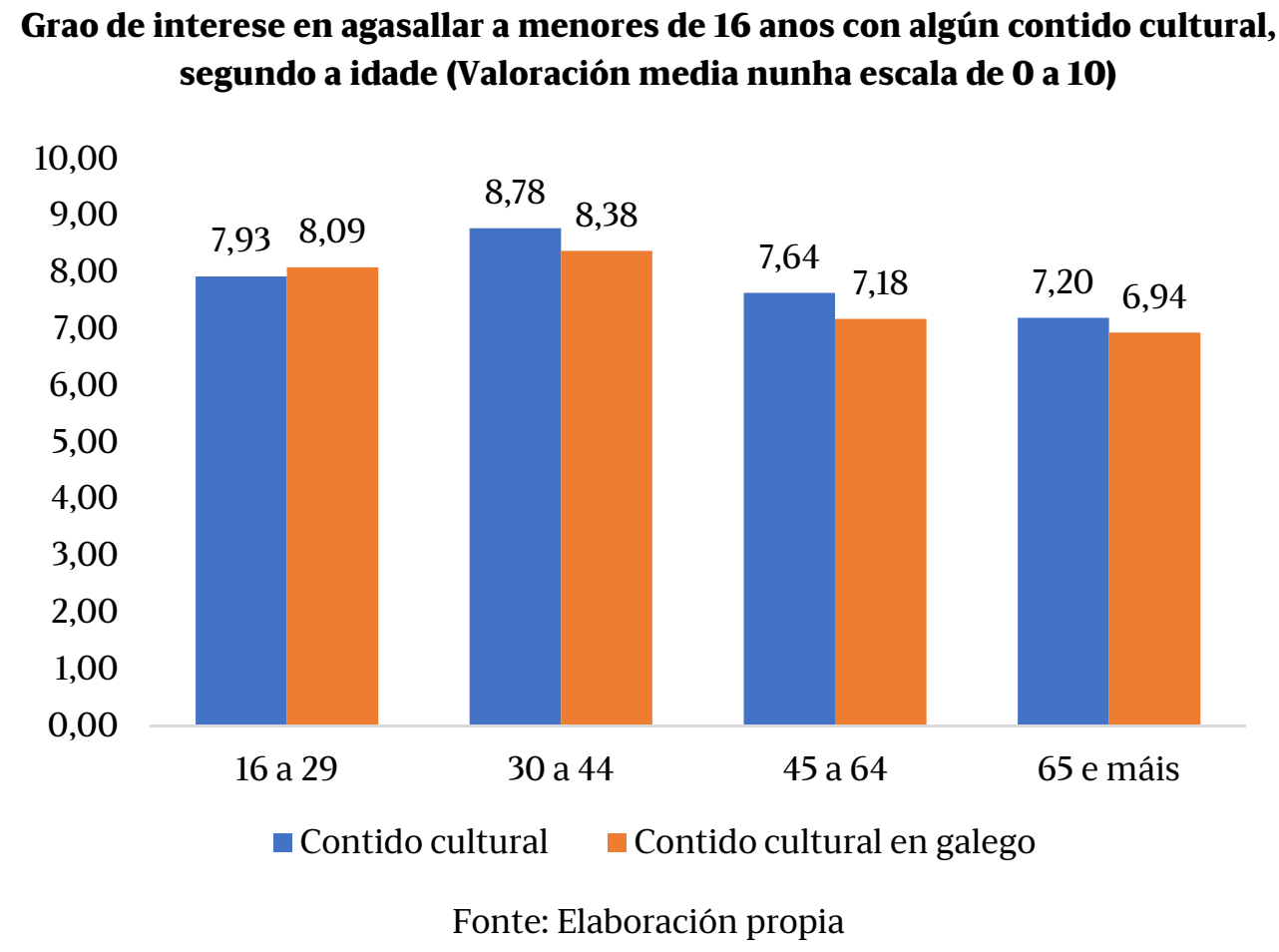

Se se ten en conta a variable de provincia, verifícase que as persoas que residen na provincia de Pontevedra son as que menos interese teñen en regalar con- 
tidos culturais en xeral, mentres que as de Lugo son as que menos interese mostran en agasallar contidos culturais especificamente en galego. Cómpre destacar a escasa dispersión da provincia de Ourense, o cal indica que practicamente non existe diferenza entre a disposición a regalar produtos culturais en xeral e produtos en galego.

\section{Grao de interese en agasallar a menores de 16 anos con algún contido cultural, segundo a provincia (Valoración media nunha escala de 0 a 10)}

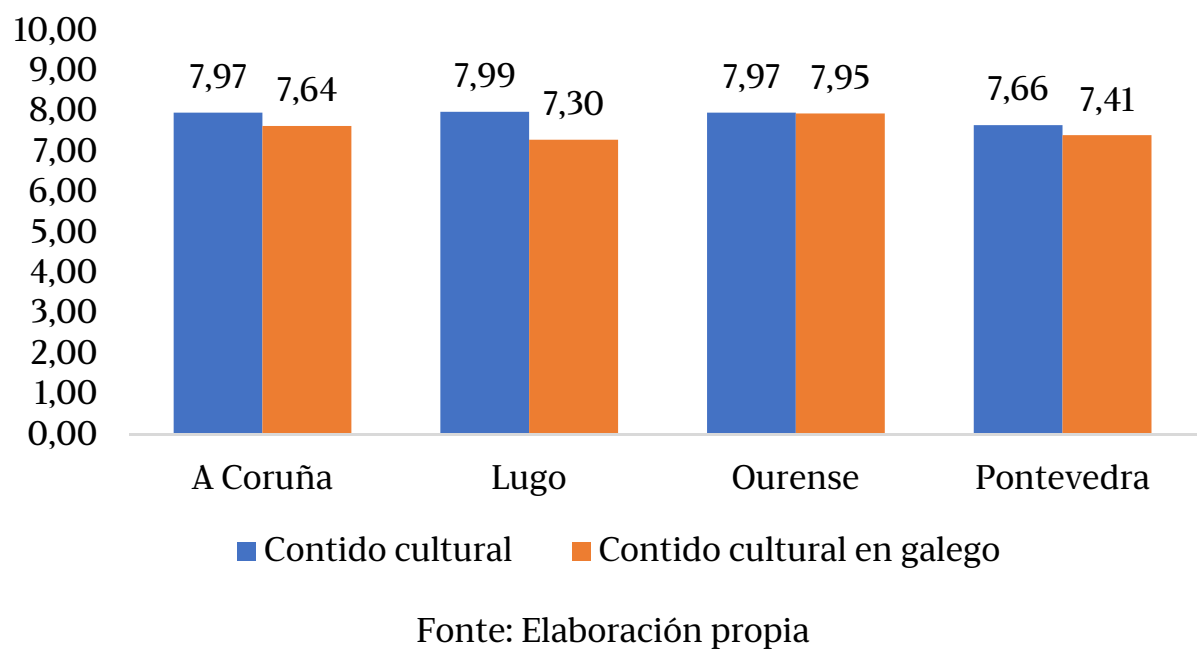

Con respecto á variable de estudos, a disposición a regalar produtos culturais, tanto en xeral como en galego, aumenta a medida que se incrementa o nivel académico acadado polas persoas entrevistadas. A dispersión, é dicir, a diferenza entre a disposición a regalar produtos culturais en galego e produtos culturais en xeral, é maior entre as persoas sen estudos. Grao de interese en agasallar a menores de 16 anos con algún contido cultural,
segundo o nivel de estudos (Valoración media nunha escala de 0 a 10)

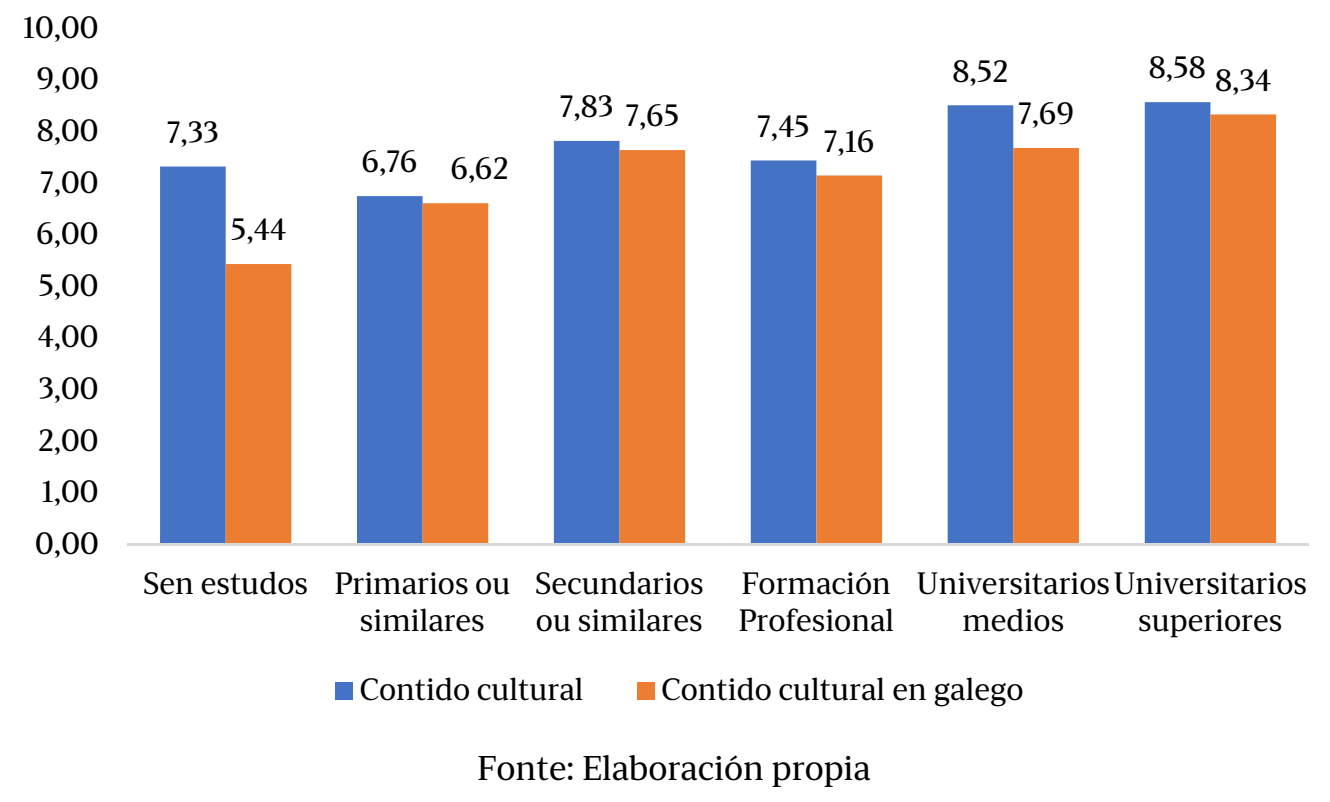

Ao comparar os resultados segundo o nivel de ocupación, obsérvase que as persoas asalariadas, as autónomas e estudantes son as que se mostran máis dis- 
postas a regalar contidos culturais. Resulta destacable que este último grupo está, así mesmo, máis disposto a regalar produtos culturais en galego que produtos culturais en xeral e que as maiores diferenzas entre a disposición a regalar produtos culturais en xeral e en galego se atopan fundamentalmente entre as persoas desempregadas e as que se ocupan dos labores do fogar.

\section{Grao de interese en agasallar a menores de 16 anos con algún contido cultural,} segundo a ocupación (Valoración media nunha escala de 0 a 10)

$$
\begin{array}{r}
10,00 \\
9,00 \\
8,00 \\
7,00 \\
6,00 \\
5,00 \\
4,00 \\
3,00 \\
2,00 \\
1,00
\end{array}
$$

0,00
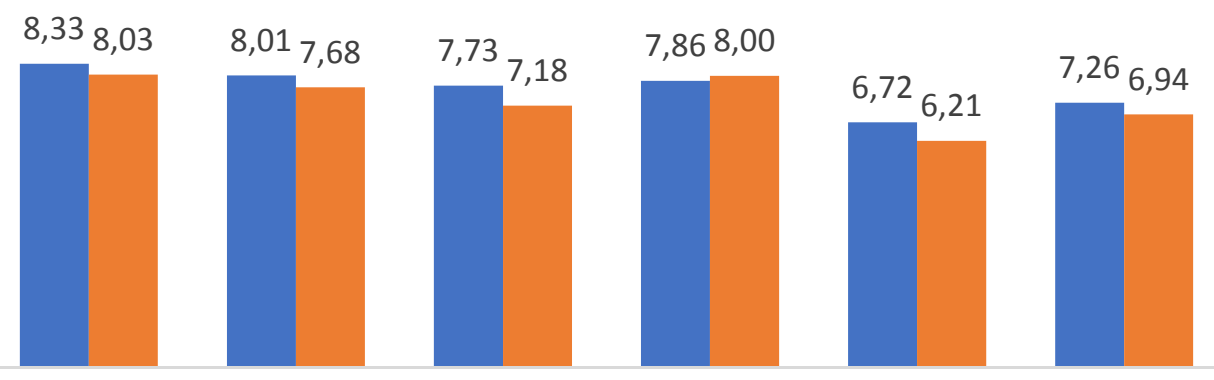

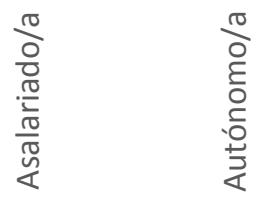
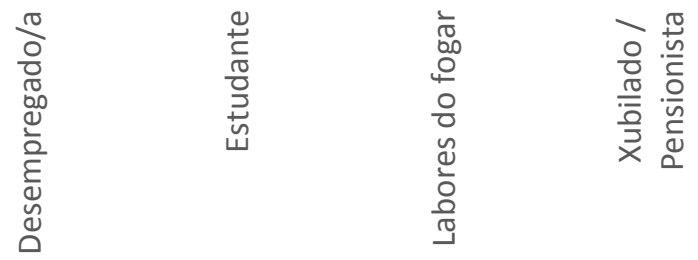

- Contido cultural Contido cultural en galego

Fonte: Elaboración propia

A variable de hábitat non mostra unha tendencia clara, dado que a disposición a regalar tende a situarse nos extremos, polo que as persoas que habitan nas cidades e nos concellos máis pequenos son as que teñen maior disposición a regalar os produtos que se veñen describindo. Resulta tamén destacable que nos concellos máis pequenos apenas hai diferenzas entre a intención de regalar produtos culturais en xeral e en lingua galega. 


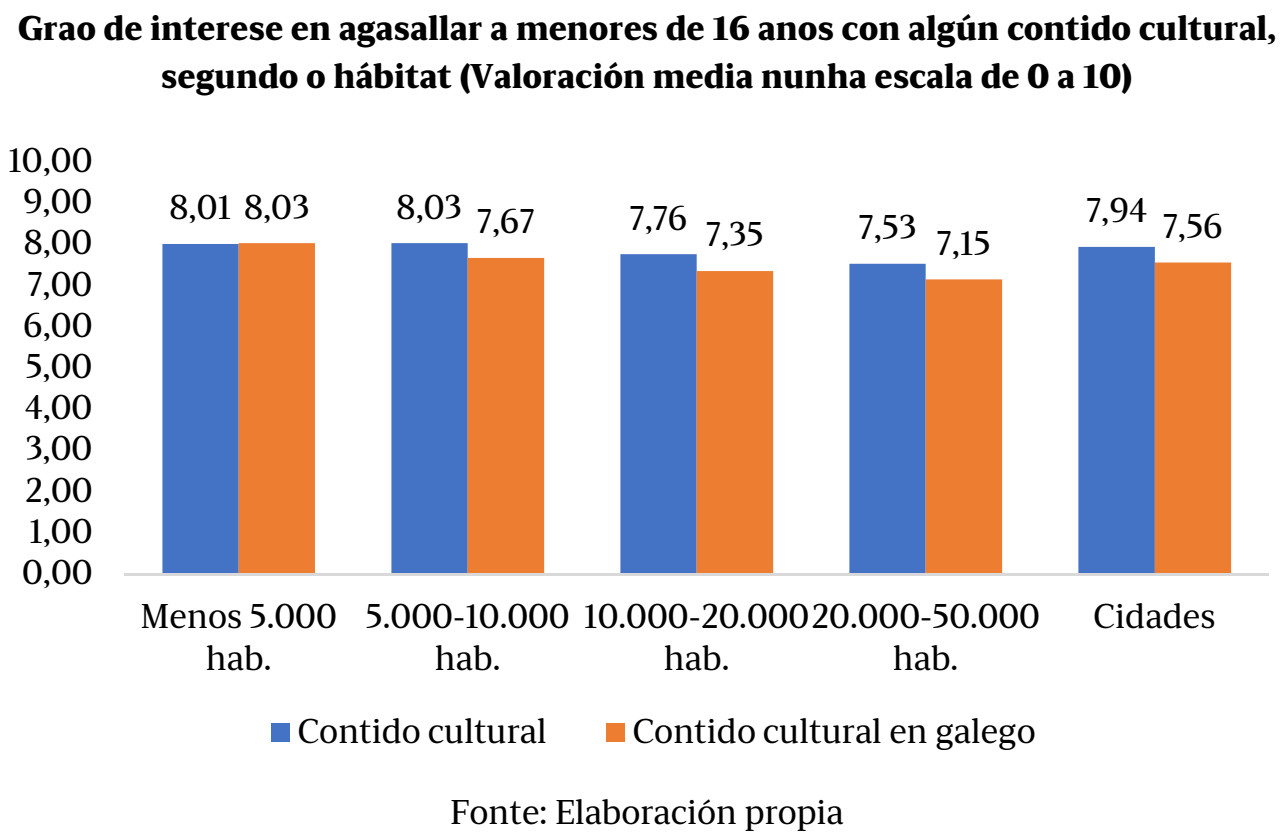

A lingua habitual e a de transmisión ás crianzas semellan ser unhas das variables máis preditivas, como podería parecer esperable. Resulta evidente que tanto as persoas cuxa lingua habitual de expresión é só o galego como as que din que as súas crianzas aprenderon a falar en galego son as que se amosan máis interesadas en agasallar contidos culturais especificamente en galego, cando as comparamos cos outros grupos.

Grao de interese en agasallar aos menores de 16 anos con algún contido cultural, segundo a lingua en que aprenderon a falar os fillos e fillas (Valoración media nunha escala de 0 a 10)

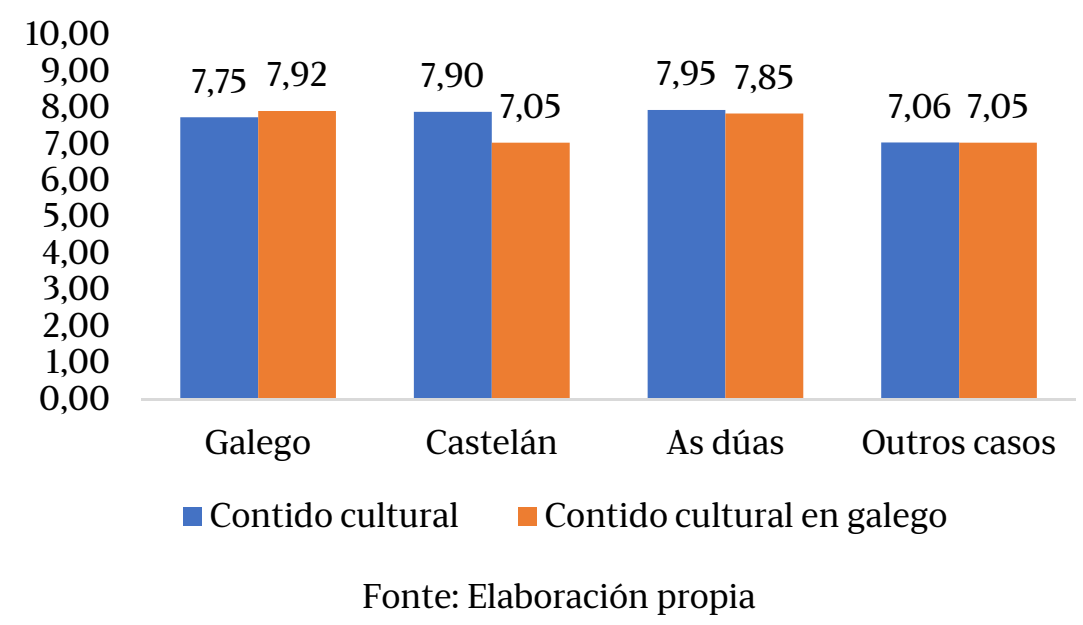

A intención de regalar produtos en galego decrece conforme aumenta o uso do castelán de forma habitual e tamén segundo o grao de exposición desta lingua na familia. Así, as familias bilingües ou galegofalantes teñen unha disposición maior a regalar produtos en galego. 
Grao de interese en agasallar aos menores de 16 anos con algún contido cultural, segundo a lingua habitual de expresión (Valoración media nunha escala de 0 a 10)

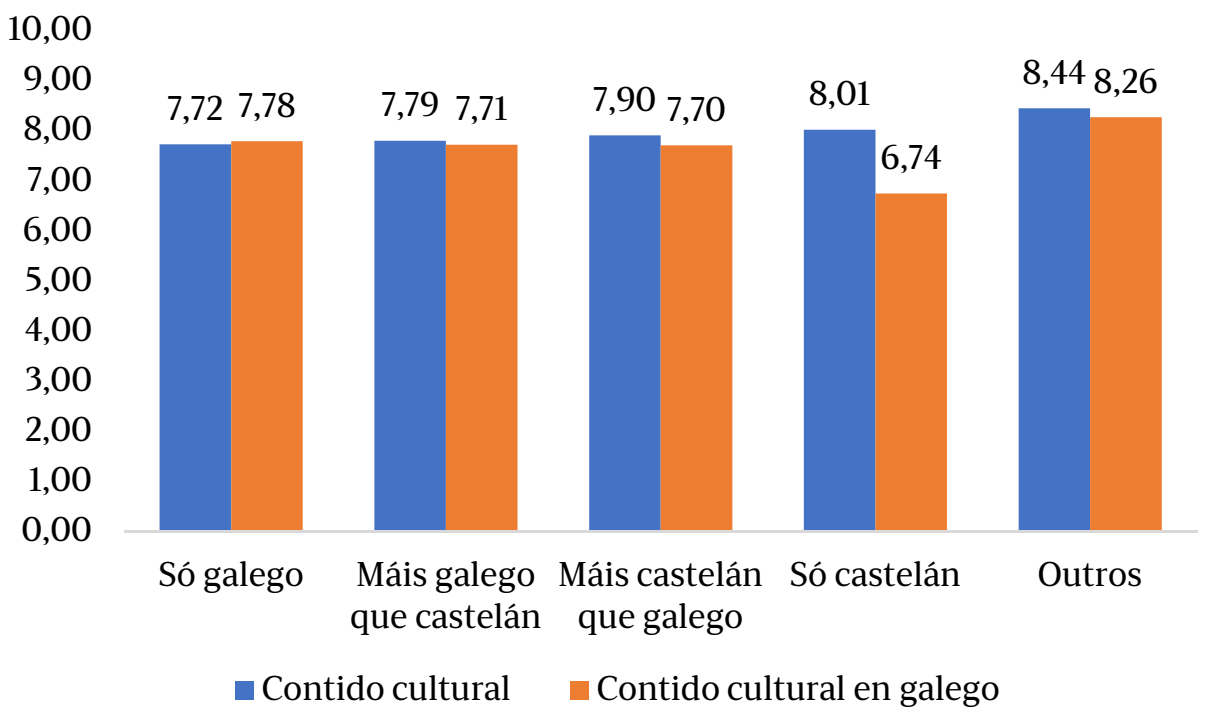

Fonte: Elaboración propia 


\section{OFERTA, DEMANDA E CONSUMO DE PRODUTOS CULTURAIS}

Neste capítulo afóndase na relación entre a falta de oferta de produtos culturais en lingua galega detectada polas persoas entrevistadas e o consumo destes mesmos produtos por parte de menores de 16 anos. Concretamente, estrutúrase en tres partes que tratan de medir a relación das principais variables dependentes do estudo, nomeadamente o consumo de produtos culturais en galego das familias, a percepción da suficiencia/insuficiencia da oferta deses produtos e, finalmente, a vontade de regalar produtos culturais en galego para a rapazada. Coma no resto do traballo, só se describen os resultados cando as diferenzas entre as variables resultaron estatisticamente significativas.

\subsection{VALORACIÓN DA OFERTA CULTURAL SEGUNDO O CONSUMO DE MENORES DOS 16 ANOS}

Neste apartado estúdase o posible vínculo entre o consumo de produtos culturais especificamente en galego entre menores de 16 anos e a valoración das persoas que conviven con eles sobre a suficiencia ou insuficiencia da oferta cultural en cada un dos casos. Para acadar estes resultados analizáronse pares de categorías idénticas, é dicir, ao estudar o consumo dun produto ou contido cultural concreto, examinouse a avaliación da idoneidade da oferta sobre ese mesmo produto (por exemplo, consumo de libros/avaliación da suficiencia ou non da oferta de libros).

Un $51,5 \%$ das persoas enquisadas que consideran que a oferta cultural de espectáculos (teatro, danza, ballet, ópera, circo, contacontos, monicreques etc.) é insuficiente convive con menores que non van nunca a este tipo de eventos. A valoración dos adultos sobre a suficiencia da oferta vai ligada estreitamente, tal e como se mostra na seguinte gráfica, ao consumo cultural dos menores cos que viven.

\section{Valoración da oferta cultural segundo o consumo de espectáculos en galego polos menores de 16 anos do fogar}

$100,00 \%$
$90,00 \%$
$80,00 \%$
$70,00 \%$
$60,00 \%$
$50,00 \%$
$40,00 \%$
$30,00 \%$
$20,00 \%$
$10,00 \%$
$0,00 \%$
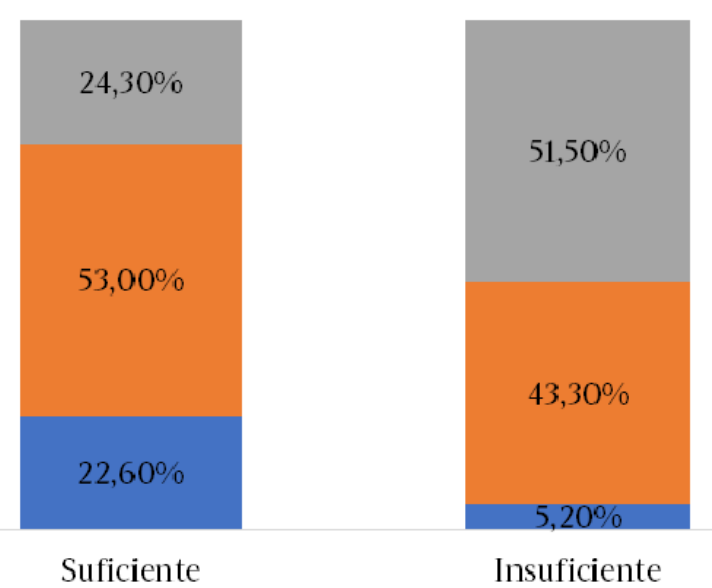

- Frecuentemente $\quad$ Ocasionalmente

Nunca

Fonte: Elaboración propia 
Esta vinculación entre o consumo cultural dos menores e a valoración da suficiencia da oferta cultural por parte das persoas enquisadas reprodúcese no caso do cine en sala en galego (cine en versión orixinal subtitulada en galego, dobrado ao galego, producido en galego etc.). Constátase que case o $95 \%$ dos adultos que pensan que a oferta de cine en galego non é suficiente convive con rapaces e rapazas que non van nunca ver filmes neste idioma.

\section{Valoración da oferta cultural segundo o consumo de cine en sala en galego por menores de 16 anos do fogar}

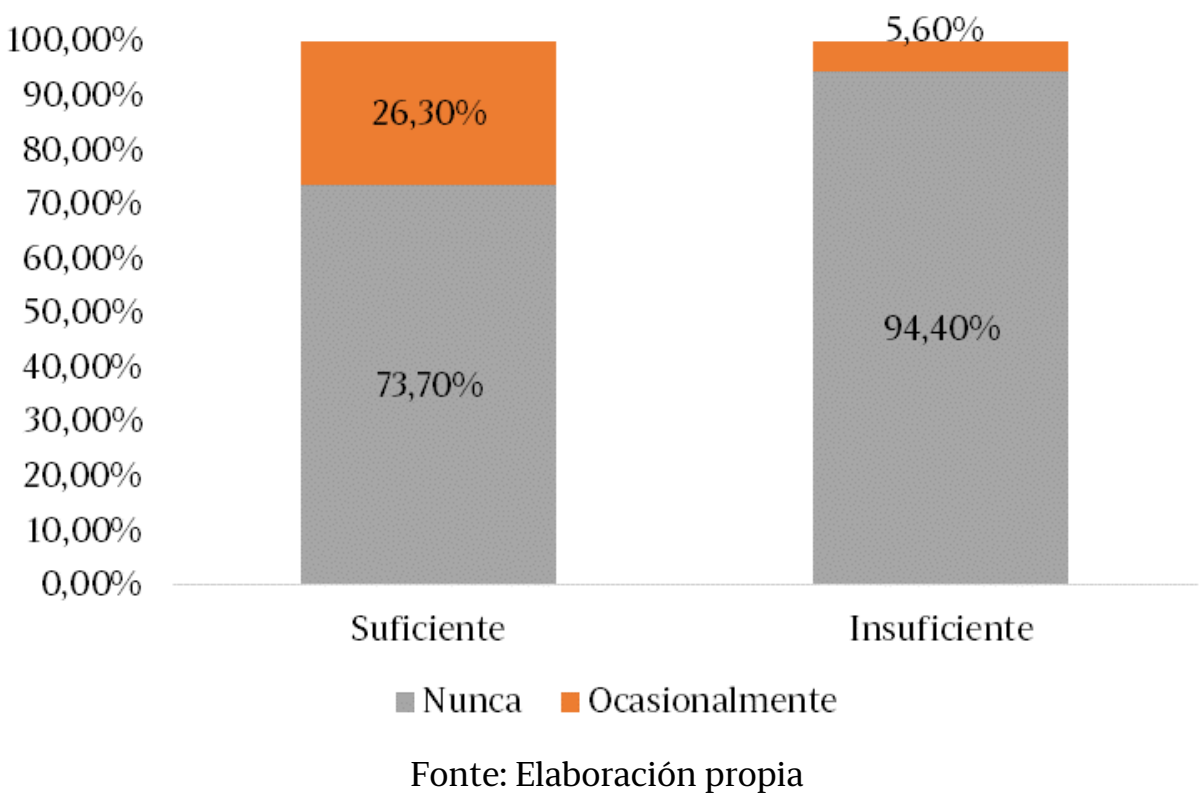

O mesmo sucede coa música en galego. $\mathrm{O} 41,5 \%$ dos adultos que cren que a oferta é insuficiente convive con menores que non consomen nunca música en galego, porcentaxe que se reduce ata ao $29,3 \%$ para quen pensa que abonda. Entre quen a considera escasa, un $18,4 \%$ reside con menores que a consomen frecuentemente e un 40,2\% cos que a desfrutan ocasionalmente. A valoración mellora canto máis consomen os rapaces e rapazas. Así, un $28,7 \%$ das persoas entrevistadas que valoran como suficiente a oferta convive con rapaces que escoitan frecuentemente música en galego, como se pode ver a continuación na gráfica. 


\section{Valoración da oferta cultural segundo o consumo de música en galego por menores de 16 anos do fogar}

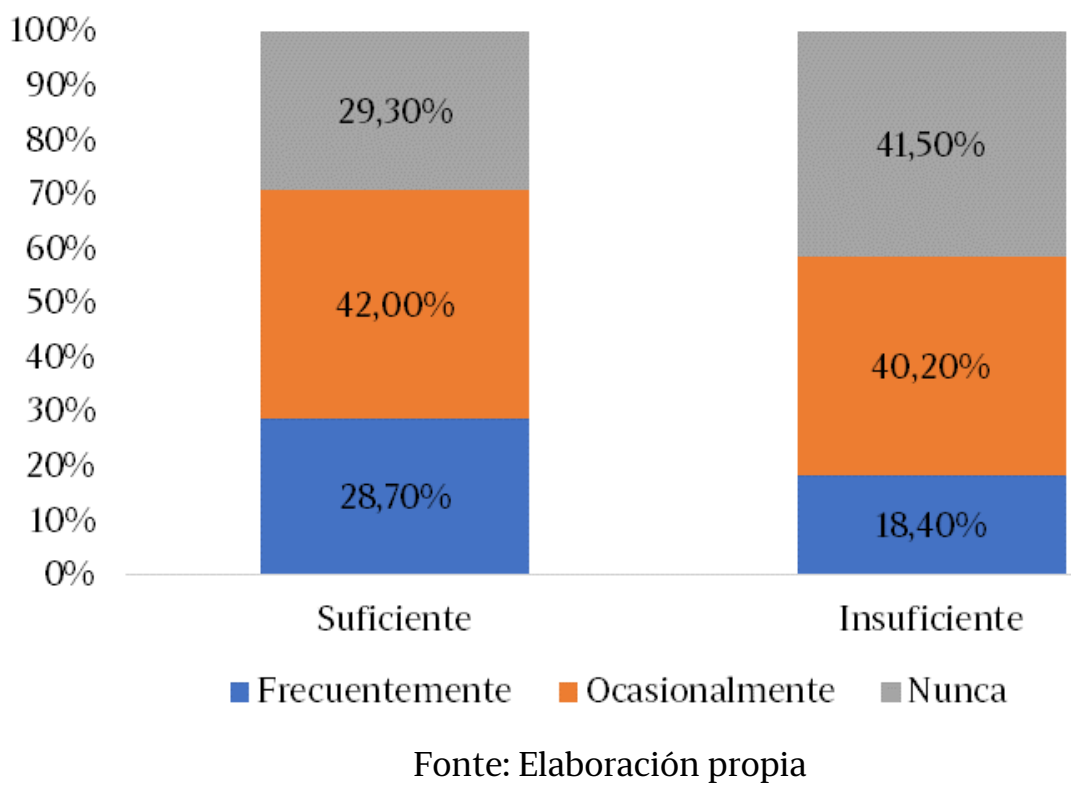

Ao analizar as visitas a museos e exposicións en galego, reitérase este comportamento. $\mathrm{O}$ 63,6\% dos adultos que consideran que a oferta de museos e exposicións é escasa convive con menores que nunca van a estes espazos, fronte ao $29,5 \%$ dos que pensan que é suficiente. A diferenza tamén é significativa entre quen reside con rapaces e rapazas que recorren ocasionalmente a este tipo de contidos culturais.

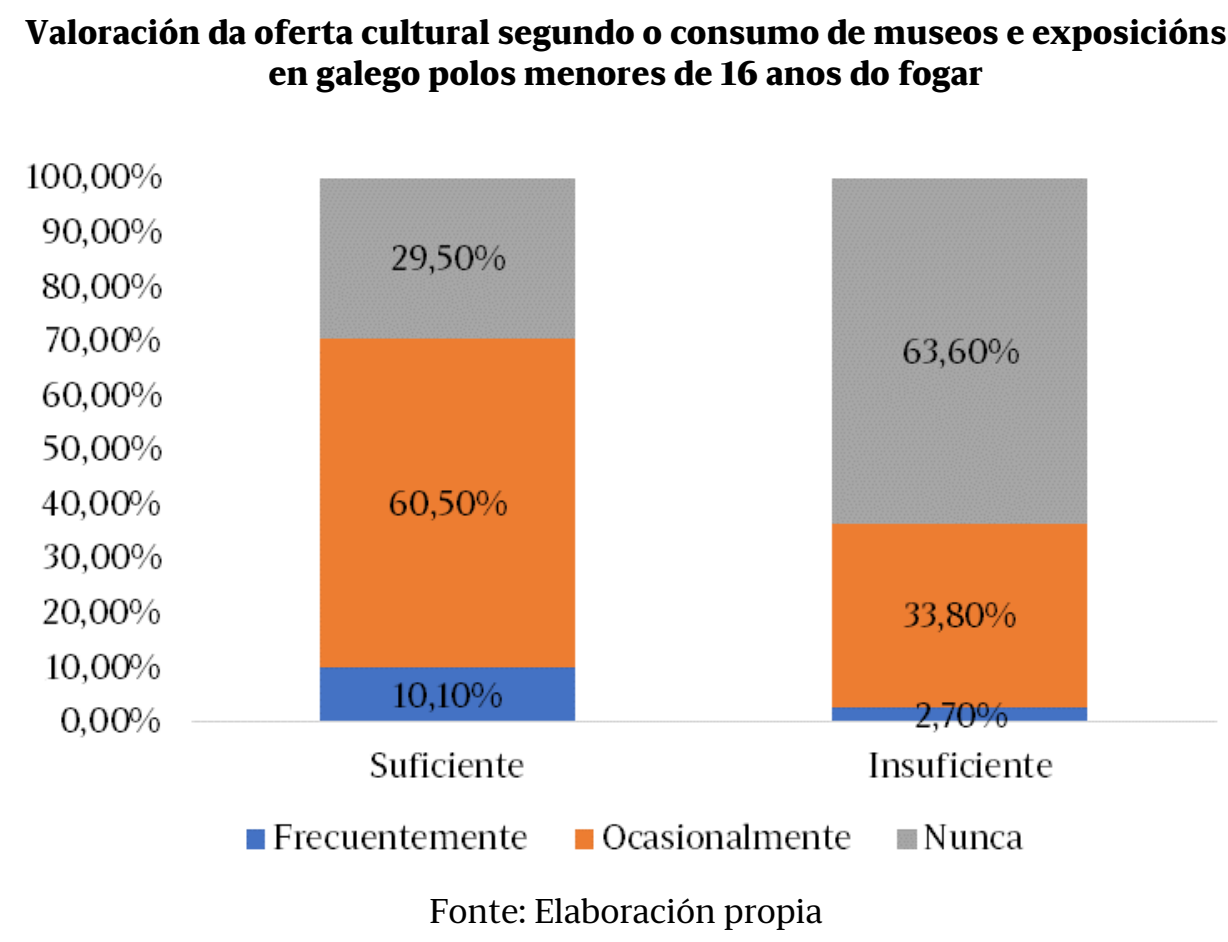

De novo, a oferta de contidos audiovisuais en galego (series, televisión á carta, canles de vídeo etc.) é valorada como insuficiente polo $55 \%$ das persoas entrevistadas que conviven con menores que nunca consomen este tipo de conti- 
dos, porcentaxe que descende case 19 puntos porcentuais entre quen a considera axeitada.

\section{Valoración da oferta cultural segundo o consumo de contidos audiovisuais en galego polos menores de 16 anos do fogar}

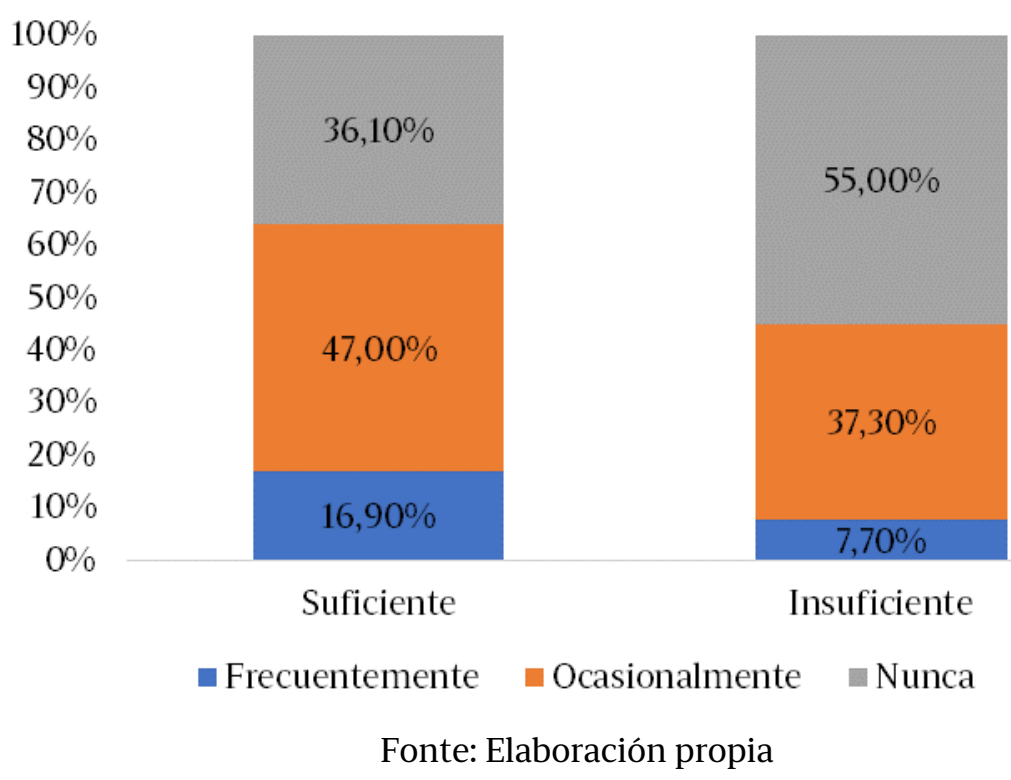

\subsection{VALORACIÓN DA OFERTA CULTURAL SEGUNDO A LINGUA DE CONSUMO DOS PRODUTOS CULTURAIS}

Esta segunda parte do capítulo pretende probar se existen diferenzas entre o consumo de produtos culturais en xeral e particularmente en galego por parte de menores, e a percepción das persoas adultas sobre a suficiencia ou non da oferta de produtos en galego. A finalidade da análise reside en concluír se hai variacións entre ambas as dúas valoracións, en función do idioma do produtos culturais que a rapazada consome.

Para a correcta interpretación dos datos extraídos, creáronse as seguintes categorías para tratar de medir a distancia entre linguas no consumo: máis en galego que noutros idiomas/só en galego, máis noutros idiomas que en galego/só noutros idiomas e en calquera dos dous casos de xeito ocasional ou frecuentemente. $\mathrm{O}$ resultado da análise foi significativo en catro tipos de produtos culturais: cine en sala, espectáculos, museos e exposicións e televisión.

Case o 93\% das persoas enquisadas que conviven con menores que asisten a salas de cine proxectado ou ben máis noutros idiomas que en galego ou ben só noutros idiomas considera insuficiente a oferta de cine en galego, case 30 puntos por riba de quen reside con nenos e nenas que ven cine en ambos os dous casos de forma ocasional ou frecuentemente, tal e como expón a seguinte gráfica. 
Valoración sobre a oferta cultural de cine en sala en galego segundo o idioma de consumo de menores de 16 anos do fogar

$$
\begin{array}{r}
100,0 \% \\
90,0 \% \\
80,0 \% \\
70,0 \% \\
60,0 \% \\
50,0 \% \\
40,0 \% \\
30,0 \% \\
20,0 \% \\
10,0 \% \\
0,0 \%
\end{array}
$$

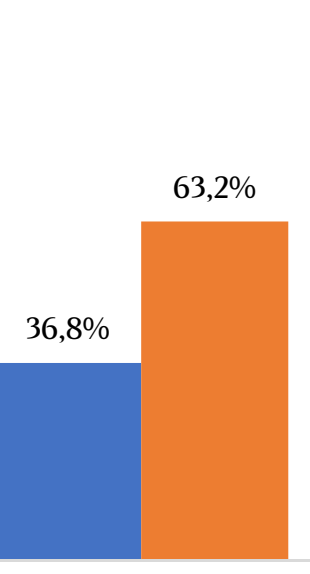

Ambos os casos ocasional/frecuentemente
$92,4 \%$

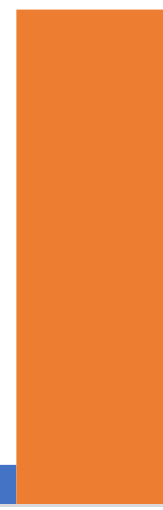

Máis noutros idiomas que en galego/Só noutros idiomas

$$
\text { - Suficiente Insuficiente }
$$

Fonte: Elaboración propia

A valoración das persoas entrevistadas en relación coa oferta de espectáculos é moi semellante. Case o 83\% das persoas adultas que residen con menores que asisten máis a espectáculos noutros idiomas que en galego ou só noutros idiomas pensa que a oferta é escasa, fronte ao $66,67 \%$ dos que conviven con rapaces que consomen este tipo de contido máis en galego que noutros idiomas ou só en galego. A porcentaxe de persoas que pensan que a oferta é axeitada é superior entre aquelas que viven con nenos e nenas que asisten a espectáculos en calquera dos dous casos, de forma ocasional ou frecuentemente (42\%).

\section{Valoración enquisada sobre a oferta cultural de espectáculos galego segundo o idioma de consumo de menores de 16 anos do fogar}

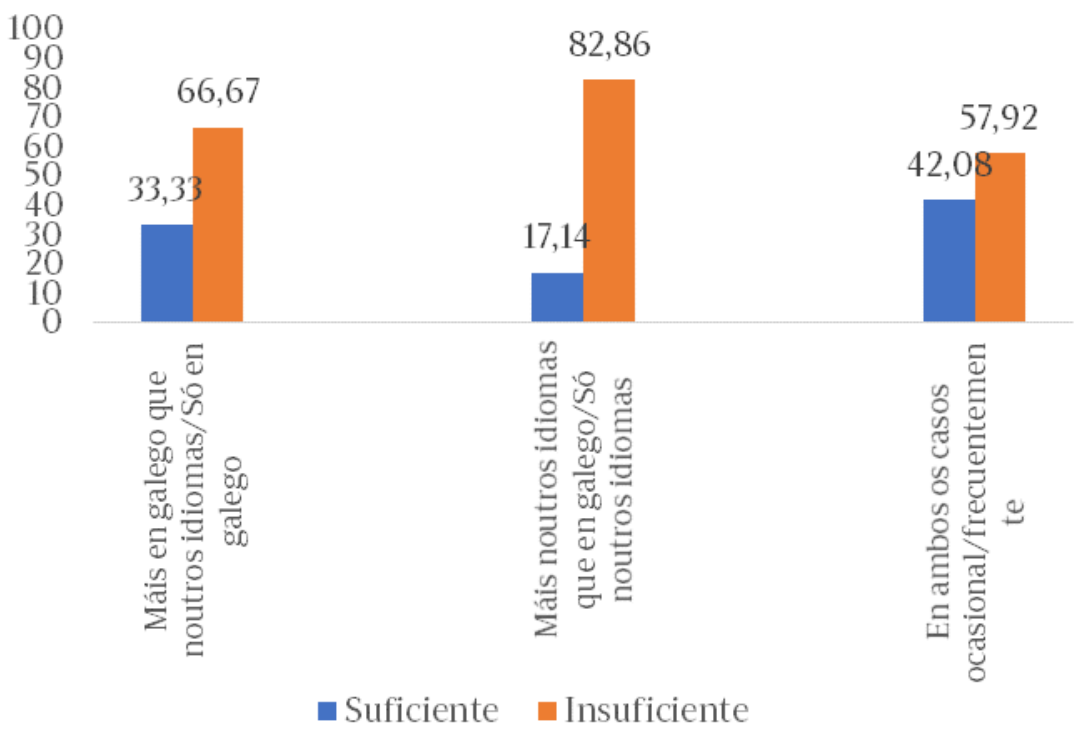

Fonte: Elaboración propia 
O 79,3\% das persoas adultas que conviven con rapaces e rapazas que acostuman visitar museos e exposicións con contidos noutros idiomas máis que en galego ou só noutros idiomas valora como insuficiente este tipo de oferta, fronte ao $46,1 \%$ no caso de quen reside con menores que o fan, tanto noutros idiomas coma en galego, de forma ocasional ou frecuentemente. Neste último caso a valoración da suficiencia supera en 7,8 puntos porcentuais á da escaseza, como se mostra a continuación na gráfica.

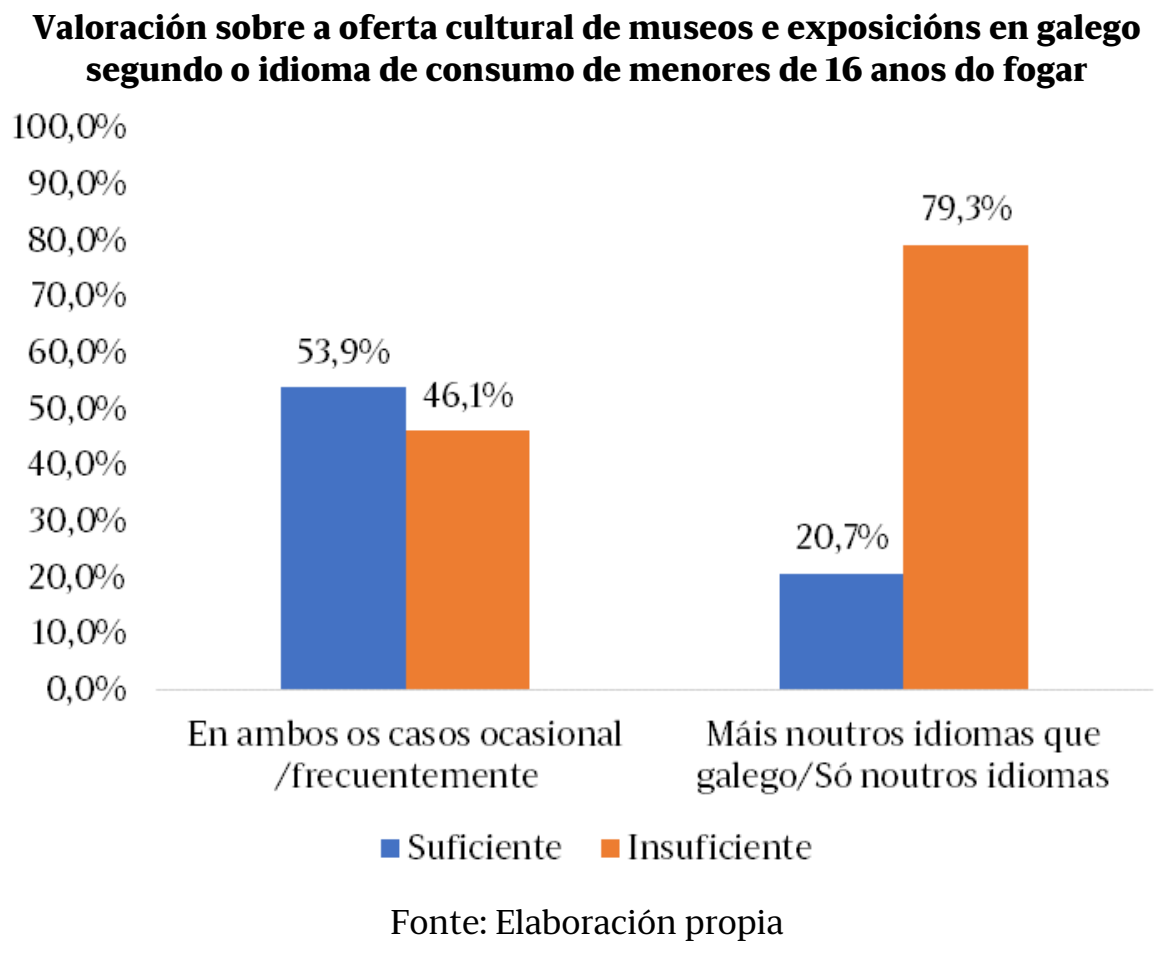

En relación coa televisión, un $62,6 \%$ das persoas enquisadas que conviven con menores que ven máis televisión noutros idiomas que en galego ou só noutros idiomas pensa que esta oferta é insuficiente, respecto ao 50,4\% de quen reside con rapaces e rapazas que consomen ocasionalmente ou frecuentemente este produto cultural en calquera opción idiomática. A diferenza na valoración da suficiencia ou non nesta última opción é de só 8 décimas porcentuais, mentres que no primeiro caso era de 25,2 puntos. 
Valoración sobre a oferta cultural de televisión en galego segundo o idioma de consumo de menores de 16 anos do fogar

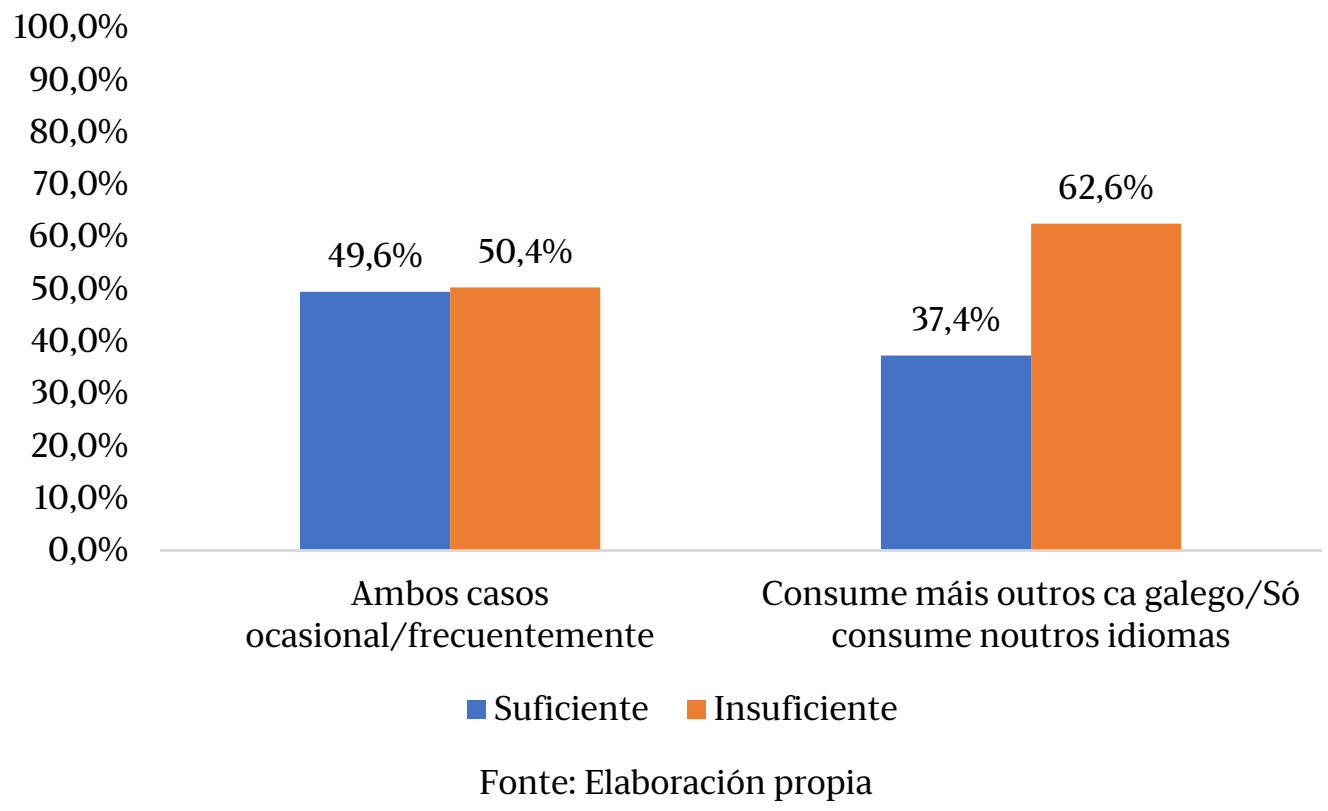

\subsection{RELACIÓN DA PERCEPCIÓN DA OFERTA COA VONTADE DE RE- GALAR CULTURA}

Neste apartado vaise medir se a percepción da abundancia ou escaseza de contidos culturais incide na vontade de regalar algún produto cultural en galego. Todos os casos resultaron significativos e en todos a puntuación media que reflicte a vontade de regalar algún contido cultural en galego é maior cando as persoas entrevistadas din que a oferta deste tipo de produtos é escasa.

Para comezar, a seguinte gráfica reflicte que as persoas que cren que a oferta de libros en galego é suficiente mostran un grao de vontade de regalar algún contido cultural en galego a menores de 16 anos elevado (cunha valoración de 7,49 puntos) e as que cren que a oferta de libros en galego é escasa manifestan aínda unha maior vontade de regalar algún contido cultural en galego (cunha valoración de 8,03 puntos). 


\section{Interese por regalar contidos culturais, segundo se se considera suficiente} ou escasa a oferta de libros en galego a menores de 16 anos

\section{Valoración media de 0 a 10}

10

9

8

7,49

7

6

5

4

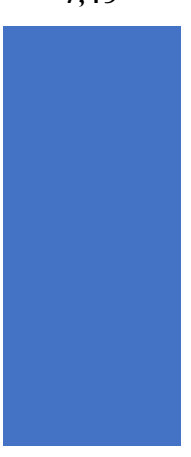

Suficiente
8,03

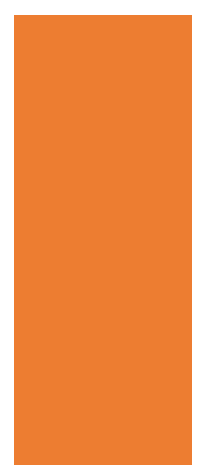

Insuficiente

Fonte: Elaboración propia

Iso mesmo acontece cando se trata da oferta de espectáculos en galego como teatro, ópera, ballet, circo ou maxia, tal como se pode comprobar na seguinte gráfica. As persoas que se mostran máis interesadas en regalar contidos culturais son aquelas que consideran escasa a oferta de teatro, ópera, ballet, circo ou maxia en galego para menores de 16 anos, con case un punto máis de valoración media con respecto ás persoas que consideran esta oferta suficiente.

Interese por regalar contidos culturais en galego, segundo se se considera suficiente ou escasa a oferta de espectáculos en galego para menores de 16 anos

\section{Valoración media de 0 a 10}

10,00
9,00
8,00
7,00
6,00
5,00
4,00
3,00
2,00
1,00
0,00

7,00

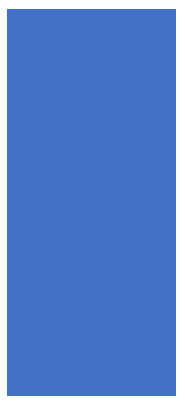

Suficiente
7,99

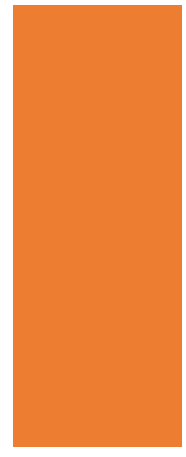

Insuficiente

Fonte: Elaboración propia 
No que a cine se refire, a situación é a mesma que nos dous casos anteriores, é dicir, que as persoas que se mostran máis interesadas en agasallar contidos culturais son as que consideran en maior medida que a oferta de cine en galego para menores é insuficiente, cunha valoración media que se achega aos 8 puntos e que supón un punto e medio máis das que xulgan esta oferta como suficiente.

Interese por regalar contidos culturais en galego, segundo se se considera suficiente ou escasa a oferta de cine en galego para menores de 16 anos

Valoración media de 0 a 10

10,00
9,00
8,00
7,00
6,00
5,00
4,00
3,00
2,00
1,00
0,00

00

8,00

7,00

6,00

5,00

4,00

3,00

2,00

1,00

0,00

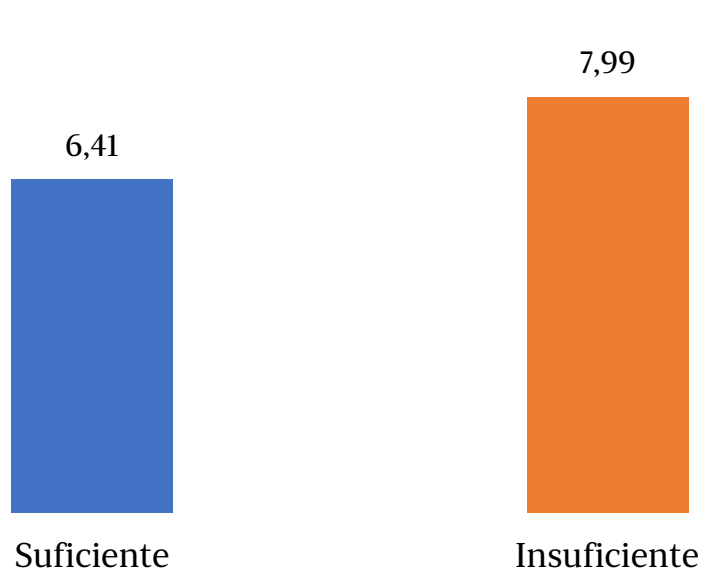

Fonte: Elaboración propia

Con respecto á música en galego, acontece exactamente o mesmo que nos outros produtos culturais analizados, cunha valoración media de case oito décimas máis entre as persoas dispostas a agasallar contidos culturais e que consideran que a oferta de música en galego para menores de 16 anos é escasa.

\section{Interese por regalar contidos culturais en galego, segundo se se considera suficiente} ou escasa a oferta de música en galego para menores de 16 anos

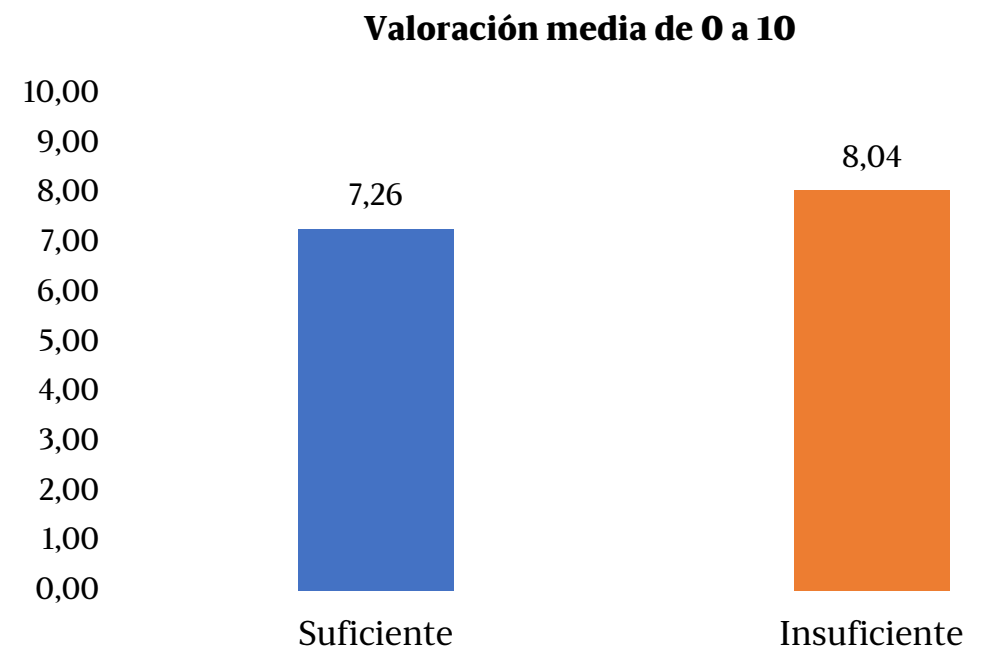

Fonte: Elaboración propia 
Esta valoración negativa que se vén comentando ao longo deste apartado increméntase aínda máis cando se trata da oferta de museos e exposicións en galego para menores de 16 anos e que é considerada insuficiente polas persoas que están dispostas a ofrecer contidos culturais a este colectivo.

Interese por regalar contidos culturais en galego, segundo se se considera suficiente ou escasa a oferta de museos ou exposicións en galego para menores de 16 anos

\section{Valoración media de 0 a 10}

10,00

9,00

8,00

7,27

7,00

6,00

5,00

4,00

3,00

2,00

1,00

0,00

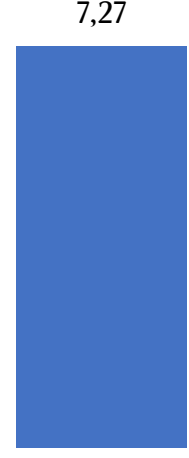

Suficiente
8,11

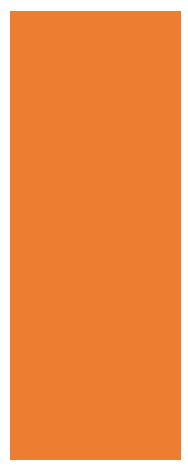

Insuficiente

Fonte: Elaboración propia

Os contidos televisivos en galego para esta franxa de idade son os que consideran máis escasos as persoas que queren proporcionar contidos culturais a menores de 16 anos, xa que esta opción acada unha valoración de 8,2 puntos sobre 10 .

Interese por regalar contidos culturais en galego, segundo se se considera suficiente ou escasa a oferta de televisión en galego para menores de 16 anos

Valoración media de 0 a 10

10,00
9,00
8,00
7,00
6,00
5,00
4,00
3,00
2,00
1,00
0,00

8,18

8,00

7,00

6,00

5,00

4,00

3,00

2,00

1,00

0,00

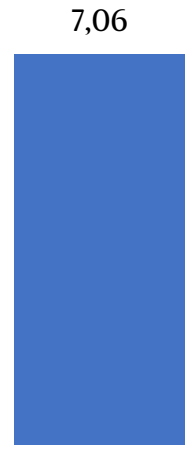

Suficiente

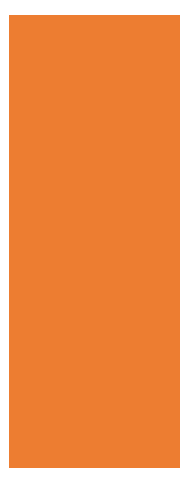

Insuficiente

Fonte: Elaboración propia 
Os contidos audiovisuais tamén obteñen unha valoración elevada cando se trata de considerar que a oferta deste tipo de contidos culturais en galego é escasa para menores de 16 anos.

Interese por regalar contidos culturais en galego, segundo se se considera suficiente ou escasa a oferta de contidos audiovisuais en galego para menores de 16 anos

Valoración media de 0 a 10

10,00
9,00
8,00
7,00
6,00
5,00
4,00
3,00
2,00
1,00
0,00

6,79

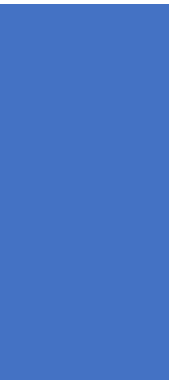

Suficiente
8,01

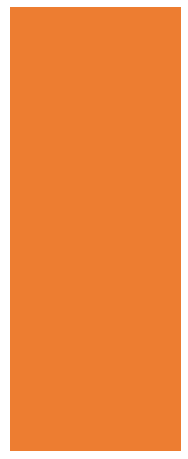

Insuficiente

Fonte: Elaboración propia

Por último, a tendencia mostrada cos anteriores contidos culturais non cambia cando se trata dos xogos en galego. Estes seguen a ser considerados insuficientes polas persoas que están en maior medida interesadas en regalar este tipo de contidos culturais á rapazada.

Interese por regalar contidos culturais en galego, segundo se se considera suficiente ou escasa a oferta de xogos en galego para menores de 16 anos

Valoración media de 0 a 10

10,00
9,00
8,00
7,00
6,00
5,00
4,00
3,00
2,00
1,00
0,00

8,03

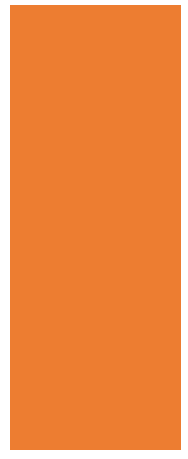

Insuficiente

Fonte: Elaboración propia 


\section{CONCLUSIÓNS}

A valoración que fai a poboación galega con respecto á oferta cultural en Galicia en xeral atópase algo por riba do aprobado. Nunha escala de 0 a 10, na que 0 sería que a considera moi escasa e 10 que cre que é moi abundante, a puntuación da oferta en cultura sitúase en 6,15. A avaliación da oferta cultural enfocada ás persoas menores de 16 anos é máis baixa e sitúase en 5,56 puntos. Por último, a oferta cultural en galego para este mesmo sector da poboación é a xulgada máis negativamente, xusto no límite do aprobado $(5,01)$. De feito, o 39,02\% da poboación puntúa a oferta en galego para a cativada por debaixo do 5.

A oferta cultural é estimada máis negativamente polas persoas cun maior nivel de estudos e polas que contan cun maior nivel de equipamento cultural nos seus fogares (equipamento físico como libros, smart TV, PC de sobremesa ou portátil, tableta, consola de videoxogos, reprodutores de música, lector de libro dixital) e tamén con subscricións a plataformas dixitais de contidos culturais. Este tipo de perfil de persoas (xunto con aquelas que viven en fogares con máis ingresos) tamén é o que cre que hai maiores desequilibrios entre a oferta cultural en xeral e a oferta en galego para os nenos. Poderíase inferir que polo seu perfil e interese manifestado son as que están máis atentas á oferta e teñen maior coñecemento dela.

Cando se lles pregunta ao conxunto das persoas enquisadas especificamente pola oferta en galego para menores de 16 anos e se analizan os distintos contidos que a compoñen, o único que a maioría da poboación percibe como suficiente é a oferta de libros en lingua galega. A oferta do resto de produtos e servizos en galego vese como insuficiente. Destaca o cine en galego, cun 76,9\% da poboación que cre que a oferta é escasa. Arredor de dous terzos da poboación tamén perciben insuficiente a oferta de contidos audiovisuais $(66,1 \%)$, de xogos (incluídos videoxogos) (66,2\%) e de espectáculos (65\%) en galego. Aproximadamente a metade considera insuficiente a oferta de música $(54,4 \%)$, museos $(54,1 \%)$ e televisión $(49,6 \%)$ nesta lingua. Como se indicou, entre as variables que inflúen na percepción de que a oferta en galego sexa escasa están o grao de equipamento cultural dos fogares e o uso de plataformas dixitais. Tal é o caso de quen ve insuficiente a oferta de cine, televisión, audiovisuais e xogos en galego. A idade tamén inflúe, polo que, canto máis novas son as persoas, en maior medida ven escasa a oferta en galego de cine en sala, música, televisión e xogos e videoxogos. En relación con isto, dentro das diferentes ocupacións da poboación galega, tenden a ser os estudantes, con maior ou menor diferenza, os que atopan escasa a oferta en galego de espectáculos, cine, musica e xogos para os menores de 16 anos. Tamén se percibe unha tendencia a valorar peor a oferta cultural nas áreas rurais. Máis concretamente, incide positivamente o feito de que canto menor sexa o grao de urbanización, máis escasa se ve a oferta en galego de espectáculos, cine en sala, contidos audiovisuais e xogos. Porén, a peor valoración da oferta en galego que se fai tamén neste hábitat semella gardar relación cunha menor oferta cultural en xeral. As persoas tamén tenden a percibir como menos abundante a oferta en galego do cine en sala, produtos audiovisuais e xogos canto maior é o seu nivel de estudos. En cambio, os ingresos do fogar só inflúen positivamente con claridade nesa percepción no caso do cine en sala. Noutros casos, pese a ser unha variable que inflúe, a tendencia non é tan obvia. É interesante 
observar que os estudantes e as persoas que conviven con menores de 16 anos e xunto cos estudantes, que poderían considerarse como perfís con coñecemento dos gustos da rapazada, perciben en maior medida como suficiente a oferta de libros en galego. Pódese engadir que este coñecemento máis próximo da realidade dos nenos e nenas opera ao revés. Por exemplo, no dos contidos audiovisuais, o 75,1\% das persoas que viven con menores considera insuficiente a oferta en galego. Algo similar acontece coa percepción da presenza de xogos e videoxogos en galego, para os que o 78,1\% de quen comparte un fogar con menores tamén ve insuficiente. Con algunha variación, dado que ás veces son as persoas bilingües e outras as monolingües as que máis demandan os contidos, a percepción de que a oferta de produtos culturais en galego para a cativada é escasa tende a aumentar coa presenza do galego na lingua habitual das persoas entrevistadas. Tal é o caso da percepción da oferta en lingua galega de libros, espectáculos, música, museos, exposicións e televisión.

En canto ao consumo de cultura que fan os menores, existe un patrón común que afecta a todos os tipos de produtos e servizos culturais analizados e que consiste en que o consumo de produtos en galego é sempre inferior ao consumo en xeral. As diferenzas atopadas e que cómpre destacar teñen que ver coas distancias que existen na frecuencia de consumo dos produtos culturais en xeral e en galego. Así, por exemplo, entre os produtos máis populares atópanse, por esta orde, música, televisión, libros, contidos audiovisuais (cine, series, vídeos...) e xogos (videoxogos, xogos tradicionais...). Todos son consumidos, en maior ou menor medida, por practicamente a totalidade da rapazada, pero con moita menos intensidade en galego. Así, se unicamente un 5,2\% da cativada non escoita música e un 5,5\% non ve televisión, esa porcentaxe elévase ata o 37,4\% no caso da música en galego e ao 37,2\% no da televisión nesa mesma lingua. O mesmo ocorre cos produtos audiovisuais, que unicamente non consome un 12,2\% da cativada (o 50,4\% se son en galego), ou cos xogos, que nunca usa o $15,2 \%$ dos menores de 16 anos (73,1\% se están en galego). O produto que presenta menores diferenzas é a lectura de libros, se ben son consumidos frecuentemente en maior medida en xeral $(68,6 \%)$ que en galego $(35,2 \%)$. Con todo, hai un $22,2 \%$ de menores de 16 anos que non le nunca libros en galego, fronte a un escaso $10 \%$ que non le libros en xeral. Outros produtos de menor aceptación como o cine en sala, os espectáculos (teatro, ópera, ballet...) ou os museos e exposicións amosan unha tendencia similar, pero a fenda entre linguas varía moito máis. Por exemplo, se ao cine en sala acode con moita ou pouca frecuencia o 69,6\% da rapazada, o 91,5\% nunca vai ver unha película en galego ao cine. En troques, nos espectáculos e nos museos e exposicións a diferenza entre linguas non é tan grande. Así, se o $64,1 \%$ vai en maior ou menor medida a museos e exposicións, a cifra só baixa ata o 46,8\% se son en galego, ou menos aínda no caso dos espectáculos $(66,8 \%$ fronte a 54,8\%). No que atinxe ás publicacións e revistas, hai que salientar que espertan pouco interese, independentemente da lingua en que estean escritas, xa que nunca as le un 66,8\% dos menores de 16 anos, porcentaxe que se eleva ata o $88 \%$ se son en galego. Ademais do anterior, existe unha coincidencia importante entre a percepción da falta de oferta e o comportamento que teñen os menores que conviven coas persoas entrevistadas á hora de consumir cultura en galego. En xeral, os produtos percibidos como máis escasos de oferta en galego coinciden cos que a rapazada consome en menor medida nesta lingua. 
Estudada a varianza para tratar de explicar que características sociais inciden no consumo de cultura entre a rapazada, atópanse algunhas tendencias que se repiten con claridade. Tal e como resulta esperable, a educación das persoas que conviven cos nenos e as nenas é unha das variables que máis inflúen no consumo de cultura. É o caso da lectura de libros, da asistencia a museos, exposicións e espectáculos ou do consumo de audiovisuais, que se incrementa conforme aumenta o nivel educativo das persoas que conviven cos menores. Outro patrón destacable e que se repite en moitas actividades é que a tendencia a consumir cultura entre as e os rapaces aumenta se as persoas que conviven con eles consomen cultura tamén. Este achado é claro no caso da lectura, no que os menores de 16 len máis cando os adultos cos que conviven len libros, revistas ou acoden a bibliotecas. Tamén correlacionan estas variables no caso da asistencia a espectáculos, a museos ou ao cine (que tamén incide positivamente no consumo doutros produtos audiovisuais). En estreita relación con isto, o grao de equipamento cultural no fogar tamén incide positivamente no consumo cultural dos menores que viven nese fogar pois, ademais de estimular as actividades anteriores, tamén promove o uso de xogos e videoxogos. Esta clara influencia do nivel educativo das familias e da presenza dunha ou doutra maneira da cultura nas casas e na vida das persoas adultas da familia garda certa independencia coa lingua do produto ou o servizo cultural en cuestión. É dicir, tamén tenden a consumir máis produtos en galego os menores que viven en fogares onde se consome máis cultura en xeral, tanto porque o nivel de equipamento do fogar é elevado, como porque os adultos da casa len, asisten a espectáculos, a museos etc. Atopouse unha menor influencia da renda das familias. Nalgúns casos a renda favorece actividades en galego, como a lectura de libros, noutros son as actividades en xeral as que se ven estimuladas, como a asistencia a museos e exposicións, e noutros, como os espectáculos, favorece tanto a asistencia en xeral como a eventos especificamente en lingua galega. Outro achado interesante é que a lingua do contorno dos menores favorece a probabilidade de asistencia ou uso dalgunhas actividades culturais en galego, pero non de todas. Son exemplos disto a lectura de libros, a televisión, o uso de xogos, o consumo de música e a asistencia a espectáculos. Tamén se detectou unha maior probabilidade de asistir a museos e espectáculos por parte de menores que viven nas provincias atlánticas fronte ás orientais.

Cando se afondou na análise de como se comportaba a relación da demanda das persoas que viven con menores co consumo que fai de produtos culturais en galego ese sector da poboación, detectouse que, no caso dalgúns produtos (espectáculos, cine, música, museos e contidos audiovisuais), as persoas que consideraban unha oferta insuficiente convivían con rapaces que precisamente consumían en menor medida en galego, polo que se pode concluír que a valoración dos adultos sobre a suficiencia da oferta está moi relacionada co acceso a produtos en galego por parte dos menores cos que viven. Trátase dun achado que reforza a relación da falta de oferta en galego cun menor consumo nesta lingua. Tamén se analizou se influía a distancia entre o consumo de produtos culturais en xeral e especificamente en galego e a percepción de falta de oferta. Os resultados indican que, nalgúns produtos, aquelas persoas que percibían que a oferta era insuficiente, era máis probable que convivisen con menores que tendían a consumir máis noutras linguas que en galego. Isto pode significar que entre os 
rapaces consumidores activos de cultura existen consumidores potenciais en lingua galega, pero que non acceden a ela por falta de oferta. Isto demóstrase con claridade nos casos do cine en sala, os espectáculos, os museos e exposicións e a televisión. Esta análise volve relacionar a falta de oferta en galego cun menor consumo.

Ás persoas que perciben insuficiente a oferta de produtos para a cativada en galego pedíuselles que concretasen cal era o tipo de contidos que botaban en falta. Pese a que a resposta máis frecuente é "de todo tipo", hai algúns contidos determinados que suscitan acordos destacables. Así, a poboación galega que considera insuficiente a oferta en galego bota en falta produtos e actividades como o teatro (45,4\%), os xogos de mesa $(36,2 \%)$, a animación e programas educativos na televisión (30,3\% e 22,9\%), a música infantil $(24,8 \%)$, a música actual $(20,7 \%)$, o cine de animación $(20,4 \%)$, o cine dobrado $(15,2 \%)$, as series e cine en liña (15,5 e 14,1\%), os videoxogos (14,9\%), os museos históricos e xacementos arqueolóxicos $(11,4 \%)$, os museos científicos divulgativos (11\%) e os museos de ciencias naturais $(10,5 \%)$.

Os contidos culturais en galego para menores de 16 anos que a poboación de Galicia considera máis interesantes para potenciar son, por esta orde, a lectura, os xogos (tradicionais, educativos...), o cine, o resto de contidos audiovisuais e o teatro. Entre a xente máis nova gaña importancia o material multimedia e, de maneira moi destacada, os videoxogos. As persoas bilingües tenden a darlle máis importancia á necesidade de potenciar os contidos audiovisuais en galego para a rapazada que as persoas monolingües. Nos fogares onde viven menores existe a tendencia a darlle algo máis de importancia á necesidade de potenciar os mencionados contidos que naqueles fogares onde non viven menores de 16 anos, pero nestes últimos dáselle algo máis de importancia á necesidade de potenciar a música para nenos.

Neste traballo investigouse tamén a disposición a agasallar cultura. En xeral, a poboación galega ten unha boa disposición para regalar contidos culturais para menores (7,9 nunha escala de 0 , que sería que non estaría nada interesado, ata 10, que estaría moi interesado). A vontade de regalar eses mesmos produtos en lingua galega redúcese un pouco, ata 7,6 puntos, en parte porque hai un pequeno conxunto de persoas (un $6,2 \%$ da poboación) que non ten ningún interese en facer este tipo de regalos se son en galego. Dentro da variación estudada, a actitude positiva de cara a regalar cultura a menores, independentemente da lingua en que se atope o soporte, increméntase co grao de equipamento cultural que teñen os fogares, cos ingresos e cos estudos. Tamén é maior entre mulleres e entre os que viven con menores de 16 anos. A diferenza entre a disposición a regalar cultura en xeral e a regalala en lingua galega é maior entre as mulleres (pese á tendencia xeral descrita arriba), entre as persoas sen estudos, desempregadas e aquelas que se dedican a labores do fogar. Como pode resultar lóxico, a distancia tamén crece conforme aumenta a presenza do castelán na lingua habitual e na lingua en que se lles fala ás crianzas. Malia esta tendencia xeral a ter unha pequena maior preferencia por regalar algún tipo de produto cultural en xeral antes que algún especificamente en galego, nalgúns segmentos de poboación a disposición a regalar en galego é superior a esa vontade xeral de regalar cultura. É o caso da xente máis nova, os estudantes e aquelas persoas que lles 
falan galego aos seus fillos. Por último, tamén se analizou como influía a percepción da oferta de produtos en galego coa vontade de regalar cultura, cuns resultados claros. En xeral, quen percibe que a oferta é insuficiente ten maior vontade de regalar cultura en galego.

En definitiva, todos os achados do traballo apuntan a que a escasa oferta cultural en galego para a rapazada incide nun menor consumo nesta lingua, pese a que se detecta unha demanda importante en practicamente todos os produtos analizados. 